http://dx.doi.org/10.18778/7525-855-4

\title{
Hamlet uzmysłowiony
}


$\frac{3}{40}$ 
Monika Sosnowska

\section{Hamlet \\ uzmysłowiony}

WYDAWNICTWO

WIWERSYTETU

ŁóDŹ 2013 
Monika Sosnowska - Katedra Studiów Brytyjskich i Krajów Wspólnoty Brytyjskiej Wydział Studiów Międzynarodowych i Politologicznych, Uniwersytet Łódzki 90-131 Łódź, ul. Narutowicza 59a

\title{
RECENZENT
}

Marta Wiszniowska-Majchrzyk

\author{
SKŁAD I ŁAMANIE \\ AGENT PR
}

PROJEKT OKŁADKI

Barbara Grzejszczak

Na okładce wykorzystano materiały dostarczone przez Autorkę

Publikacja dofinansowana z dotacji celowej MNiSW na 2012 r. na prowadzenie badań naukowych lub prac rozwojowych oraz zadań z nimi związanych, służących rozwojowi młodych naukowców

(C) Copyright by Uniwersytet Łódzki, Łódź 2013

Wydane przez Wydawnictwo Uniwersytetu Łódzkiego

Wydanie I. 6067/2012

ISBN (wersja drukowana) 978-83-7525-855-4

ISBN (ebook) 978-83-7969-373-3

\author{
Wydawnictwo Uniwersytetu Łódzkiego \\ 90-131 Łódź, ul. Lindleya 8 \\ www.wydawnictwo.uni.lodz.pl \\ e-mail: ksiegarnia@uni.lodz.pl \\ tel. (42) 6655863 , faks (42) 6655862
}


„Hamlet powinien już być Krezusem. Któż nie dorzucał od wieków swoich trzech groszy do jego monologu!"

Stanisław Jerzy Lec, Myśli nieuczesane 



\section{Podziękowania}

Wyrazy wdzięczności pragnę skierować w pierwszej kolejności do Pani Prof. Krystyny Kujawińskiej Courtney, promotor mojej pracy doktorskiej. Jej wskazówki i porady były dla mnie drogowskazem na każdym etapie przygotowań Hamleta uzmysłowionego.

Chciałabym także bardzo serdecznie podziękować Pani Prof. Marcie Wiszniowskiej-Majchrzyk, recenzent mojej pracy, której wnikliwe komentarze i pomoc udzieloną mi w trakcie powstawania pracy, uważam za nieocenione.

Jestem wdzięczna Panu Prof. dr hab. Tomaszowi Domańskiemu, Dziekanowi Wydziału Studiów Międzynarodowych i Politologicznych Uniwersytetu Łódzkiego oraz Radzie ds. Nauki WSMiP za przyznanie mi grantu na publikację tej pracy. Książka powstała, dzięki dofinansowaniu w ramach dotacji Ministerstwa Nauki i Szkolnictwa Wyższego na zadania służące rozwojowi młodych naukowców.

Specjalne podziękowania należą się bardzo życzliwemu Kierownictwu oraz Pracownikom Wydawnictwa Uniwersytetu tódzkiego, dzięki którym książka ukazuje się właśnie w takiej formie, jak sobie zaplanowałam. Bardzo dziękuję Pani Dr Bożenie Walickiej za dokonanie redakcji naukowej oraz korekty tekstu Hamleta uzmysłowionego.

Najbardziej osobiste podziękowania za nieustające wsparcie podczas pisania pracy kieruję do moich Najbliższych, posiadających nieznane mi pokłady cierpliwości. 



\section{Spis treści}

„Uprzejmość niewidomych” Wisławy Szymborskiej ............... 5

Zamiast wstępu, czyli o tym, jak uzmysłowić (sobie) zmysły ...... 7

Rozdział 1. Kulturowa architektura zmysłów

Percepcyjne ekscesy - rzecz o niepokornej teorii naukowej ............ 15

„Nie taki zmysł naturalny, jak go malujq”........................ 17

Wybór między "dobrą" a „złq" wersja „Hamleta” ................... 23

Rozdział 2. Ślady życia sensualnego $\mathrm{z}$ dawnej epoki

Na pozór nieuchwytne - zmysły w literaturze ..................... 29

Zmysły daja się „nakręcić".................................... 31

Bohaterowie „Hamleta” jako (mniej bądź bardziej uważni) obserwatorzy i słuchacze .............................................

„Hamlet" $i$ dwa efekty fabuły: wizualny (dramatyczny) i werbalny (narracyjny) ............................................... 37

„Hamlet” intertekstualny, czyli zwiq̨zek literatury z filmem ............ 40

Rozdział 3. Zmysły w teatrze, filozofii i medycynie w okresie wczesnej nowożytności

„Miejcie oczy i uszy otwarte" ..................................

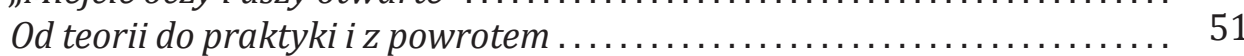

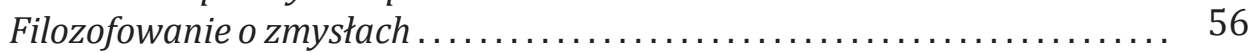

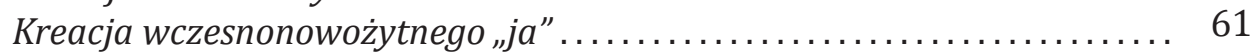

Rozdział 4. Dramat Hamlet dramatem zmysłów

Jak rozszyfrować "kod sensoryczny” dramatu? .......................

„Źle się dzieje w państwie duńskim” - percepcyjne konsternacje wokół zjawisk nadprzyrodzonych ....................................

Między prawdq a fałszem, autentycznościq a pozorem - relacje między bohaterami.... 
Sieć dworskich informatorów ................................ 85

„Czyliś jest zbawionym duchem, / Czy potępieńca zjawq, czy owiany /

Niebiańskq woniq, czy piekielnym wichrem" (1.4.730-732)?......... 90

Wątki szpiegowskie - śledzony Hamlet w roli śledczego............... 96

Sztuka zastawiania zasadzki................................. 101

„Pułapka na myszy” albo pułapka na zmysły....................... 108

„Przemawianie sztyletami” $i$ „pokazywanie duszy głębi”................ 114

Pomieszanie zmysłów, czyli szaleństwo Ofelii ...................... 120

„Reszta jest milczeniem” - krwawy widok sceny finałowej .............. 125

Rozdział 5. Zmysły na ekranie: nowa zmysłowość Hamleta

Trzy razy „Hamlet” filmowy: 1990, 1996, 2000 ..................... 129

Pierwsze ujęcia a pierwsze wrażenia zmysłowe bohaterów i widzów ...... 134

Różne wizje zjawy na ekranie ................................ 139

Widzieć i być widzianym, słyszeć $i$ być słyszanym - relacje wzrokowe

i słuchowe między filmowymi postaciami dramatu ................. 143

Matnia intryg szpiegowskich w Elsynorze Zeffirellego, Branagha i Alme-

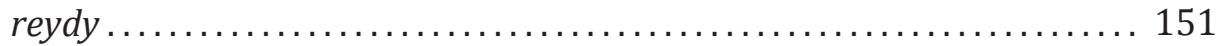

Aberracyjne, filmowe zachowania Ofelii ....................... 168

Zmysły a skutki sceny finałowej ............................... 180

Zakończenie, czyli dlaczego Hamlet (jest) uzmysłowiony ......... 185

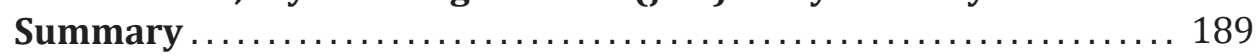

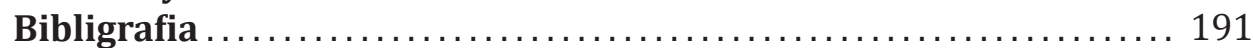

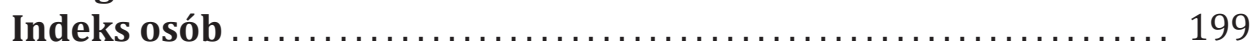




\section{Uprzejmość niewidomych}

Poeta czyta wiersze niewidomym.

Nie przewidywał, że to takie trudne.

Drży mu głos.

Drżą mu ręce.

Czuje, że każde zdanie

wystawione jest tutaj na próbę ciemności.

Będzie musiało radzić sobie samo,

bez świateł i kolorów.

Niebezpieczna przygoda

dla gwiazd w jego wierszach, zorzy, tęczy, obłoków, neonów, księżyca,

dla ryby do tej pory tak srebrnej pod wodą

i jastrzębia tak cicho, wysoko na niebie.

Czyta - bo już za późno nie czytać -

o chłopcu w kurtce żółtej na łące zielonej,

o dających się zliczyć czerwonych dachach w dolinie,

o ruchliwych numerach na koszulkach graczy

i nagiej nieznajomej w uchylonych drzwiach.

Chciałby przemilczeć - choć to niemożliwe -

tych wszystkich świętych na stropie katedry,

ten pożegnalny gest $\mathrm{z}$ okna wagonu,

to szkiełko mikroskopu i promyk w pierścieniu

i ekrany i lustra i album z twarzami.

Ale wielka jest uprzejmość niewidomych,

wielka wyrozumiałość i wspaniałomyślność.

Słuchają, uśmiechają się i klaszczą.

Ktoś z nich nawet podchodzi

z książką otwartą na opak

prosząc o niewidzialny dla siebie autograf.

Wisława Szymborska (Wiersze wybrane, zbiór Dwukropek, 2006) 



\section{Zamiast wstępu, czyli o tym, jak uzmysłowić (sobie) zmysły}

O tym, że zwodzą na manowce, psują szyki dnia codziennego, plączą nasze myśli, ale też jednocześnie ułatwiają orientację, czynią świat znośnym w jego złożoności, uświadamiają obecność innych istot, przekonujemy się nieustannie. One to właśnie czynią rzeczywistość widzialną, słyszalną, zapachową, smakową i dotykową. Każdy z osobna bierzemy za pewnik, by nabrać przeświadczenia o własnej naiwności dopiero wtedy, gdy nasze sensorium zawodzi.

Instrumentalne traktowanie ciała, a przez to również aparatu postrzegania zmysłowego, rzadko dopuszcza refleksję nad tym ostatnim. Ten nietypowy stan „uzmysłowienia sobie zmysłów” może być spowodowany sytuacjami ekstremalnymi, na przykład upośledzeniem jednego z narządów percepcji albo odbieraniem bodźców przypisanych jednemu ze zmysłów przez inne, m.in. smakowanie barw czy też widzenie dźwięku. Pojawiają się ponadto mniej graniczne doświadczenia, jak choćby rozmywający się obraz, wynikający ze zmęczenia narządu wzroku, niedosłyszenie na skutek panującego dookoła hałasu lub przyjemnie drażniący zmysł powonienia zapach wypiekanego ciasta.

Niektóre spośród doświadczeń sensualnych są bezcenne, wzbogacają nasze istnienie o bycie $\mathrm{w}$ świecie wrażeń niejednokrotnie niedefiniowalnych. Można pokusić się o stwierdzenie, że kalejdoskop doznań płynących od zmysłów wykracza poza ramy językowe. Czy bowiem uda się ubrać w słowa nieregularne tempo złożone z dźwięków przechodzące w płynnie ułożone brzmienia, odbierane przez zmysł słuchu jako muzyka? Czy niewidomi z wiersza Wisławy Szymborskiej słyszą wiersz recytowany przez poetę niczym muzykę? Czy jego drżący głos odbierają jako fałszowanie, a każde słowo ewokujące cudowność widoków przypomina im o niemożliwości wydostania się z wiecznej krainy ciemności? Nie, oni „słuchają, uśmiechają się i klaszczą”. Wypróbowują swoje pozostałe zmysły, wystawiają je na próbę „odczuwania wszystkimi zmysłami", bo właśnie temu jedynemu, cenionemu przez kulturę 
Zachodu najwyżej, najważniejszemu ze wszystkich - racjonalnemu, oświecającemu, niemalże boskiemu w swej nieomylności - symbolizowanemu przez oko, zmysłowi wzroku w przypadku niewidomych „odwidziało się” widzieć.

Dopiero konfrontacja z tak przejmującym widokiem (poetycko naświetlonej) „uprzejmości niewidomych” (kłopotliwa kwestia dla widzących) budzi tych, którzy spokojni o kondycję własnych zmysłów, nagle uświadamiają sobie wagę problemu. Pierwszym odruchem byłaby pewnie troska o stan zmysłu wzrokowego w jego biologicznej odsłonie. Być może druga reakcja sprowadzałaby się do głębszego wejrzenia w sedno problemu - w jego kulturową istotę. Na ile przyjęcie takiej perspektywy rozbudzi te rejony naszej świadomości, które zwykle pozostają w stanie błogiego drzemania? Co oznaczałoby przekroczenie przez zmysły bram natury i wkroczenie do imperium zmysłów? Czy to przejście uwolniłoby je od ciężaru biologicznej odpowiedzialności za jakość funkcjonowania i obarczyło nim obszar kultury? Czy zmieniłaby się też terminologia opisująca stan naszych zmysłów, rugując chociażby takie określenia (w odniesieniu do widzenia) jak zez czy astygmatyzm i zastępując je niemedyczną diagnozą? By dać próbkę kulturowego rozpoznania w zakresie możliwości narządu wzroku, odwołam się do fragmentu utworu Stanisława Barańczaka, który w Spójrzmy prawdzie w oczy zachęca, byśmy zajrzeli:

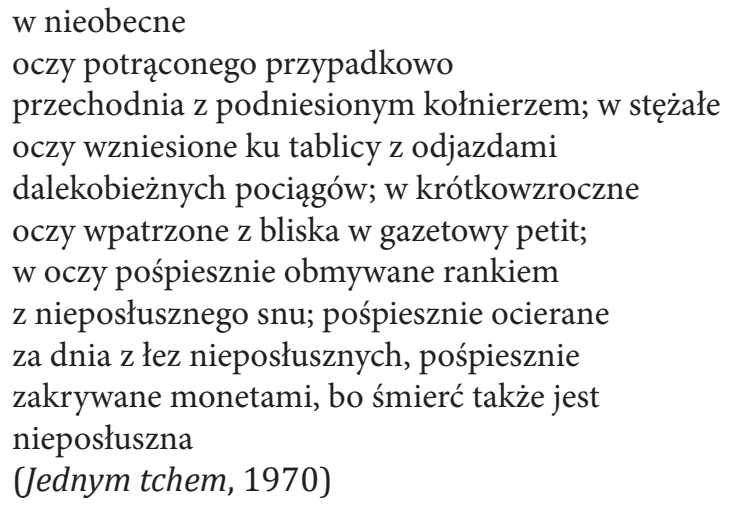

Zacytowany wyżej fragment wiersza w metaforyczny sposób unaocznia liczne znaczenia i role przypisywane narządowi wzroku w kulturze. Mamy zatem pewność co do „zastygłych w jednej pozie” gałek ocznych, będących oznaką śmierci, albo staramy się interpretować znaczenie łez, które niektórzy wylewają, inni zaś potajemnie ronią. Nie przez przypadek odwołuję się do zmysłu wzroku i jego związków z kulturą, bo cechą charakterystyczną kultury współczesnej, zwanej też mianem postmodernistycznej, jest jej „przepełnienie" obrazami, prowadzące do przesycenia różnymi formami wizual- 
nymi ${ }^{1}$. Badacze, na przykład Martin Jay (1994), mówią o wzrokocentryzmie albo okulocentryzmie kultury zachodniej, osiągającym swe apogeum właśnie w czasach postmodernistycznych, zwłaszcza w fazie okołomilenijnej. Fenomen kulturowej dominacji wzroku zostanie omówiony w dalszej części książki, ale już tutaj warto zaznaczyć, że definicja tego pojęcia wyjaśnia je jako „zjawisko zauważalnego uprzywilejowania pewnego rodzaju schematów poznawczych, metafor, sposobów ujmowania rzeczywistości i kreowania artefaktów" (Przeźmiński, 1998: 331). Chodzi tu o stopniowo osiąganą od czasów wczesnej nowożytności, hegemonistyczną pozycję zmysłu wzroku w różnych dziedzinach wiedzy i działalności ludzkiej². Dlaczego jednak w ogóle problematyzować ludzkie zmysły, podnosząc je do rangi zagadnienia kulturoznawczego? Dlaczego „wyrywać” zmysły naturze, próbując uwikłać je w dylematy kultury? Dlaczego w świecie zmysłów poszukiwać paradygmatu, według którego funkcjonuje świat społeczny?

Prawdopodobnie jednym z wyjaśnień jest chęć odtworzenia historii człowieka sensualnego, czyli takiego, którego dzieje zawsze odsyłają do niego samego; którego sposób myślenia, ideologie, ustroje, w jakich funkcjonował, wartości, jakie uznawał lub którym się przeciwstawiał, sposoby odczuwania i ekspresji (także językowej), odsyłają do zmysłów. Szczególnie istotny w dziejach człowieka jest właśnie wzrok, nie tylko ze względu na jego biologiczną użyteczność. Zrozumienie znaczenia tego zmysłu i jego roli wśród innych zmysłów w kulturze wiąże się z uznaniem wzrokocentryzmu za nadrzędną zasadę, organizującą funkcjonowanie przestrzeni społecznej na Zachodzie. Stąd też w licznych fragmentach omawiam właśnie kulturowe znaczenie wzroku, często „na niekorzyść” słuchu³. Przykładowo, symbolika oka,

\footnotetext{
${ }^{1}$ Postmodernizm należy rozumieć jako okres odnoszący się do kultury współczesnej, rozwijającej się od lat pięćdziesiątych XX wieku.

${ }^{2}$ Okres wczesnonowożytny będzie rozumiany w dalszej części książki w sposób umowny, jako czasy przypadające na lata 1500-1700. Taką periodyzację proponuje Chris Baldick w The Oxford Dictionary of Literary Terms (2008). Zamiennie może pojawiać się też określenie „renesans", mające znacznie dłuższą tradycję znaczeniową. Możliwość wymiennego stosowania obu terminów pojawiła się dopiero w latach osiemdziesiątych XX wieku, na co miały wpływ liczne debaty historyków i badaczy literatury (2008: 101). Jednak ostatecznie - jak podaje Baldick - to termin „wczesnonowożytny” okazał się bardziej neutralny i chronologicznie precyzyjny aniżeli określenie „renesansowy”. Wśród argumentów przemawiających za „większą użytecznością" tego pierwszego terminu można wymienić następujące: słowo „renesans” jest bardziej obciążone tendencją do podkreślania rozwoju sztuki (szczególnie w XIV i XV wieku we Włoszech) na niekorzyść rozwoju dziedzin pozaartystycznych, takich jak druk czy protestantyzm; wczesna nowożytność w mniejszym stopniu kontrastuje ze średniowieczem, które zostało pomyślane przez renesansowych humanistów jako okres odznaczający się uwstecznieniem, a z tego powodu niższością kulturową w stosunku do ich epoki oraz epoki starożytnej (101).

${ }^{3}$ Wzrok stanowi zmysł, któremu najczęściej „przyglądają się” badacze z różnych dziedzin, także w ramach studiów kulturowych. David Howes proponuje, by badacze zajmujący się studiami sensorycznymi „zwrócili swe oczy” w stronę innych zmysłów i nie przyczyniali się
} 
wyrażana przez „Oko Opatrzności”, rozciąga się od tak rozpoznawalnych wizerunków, jak: Trójca Święta w chrześcijaństwie, poprzez ścięty stożek piramidy na rewersie banknotu dolara amerykańskiego, czy też ten sam symbol co na banknocie, zaadaptowany przez kulturę popularną w filmie Rozpaczliwie poszukując Susan (1985), tyle że umieszczony na kultowej kurtce (bohaterki granej przez Madonnę) w formie wyszywanej aplikacji.

Czy równie łatwo przychodzi na myśl odpowiednik tej symboliki związany ze zmysłem słuchu? Czy sfera symboliczna jest również bardziej „rzucająca się w oczy" i zdominowana przez to, co wizualne, a nie audialne? Czy w takim razie nasza współczesność różni się od poprzednich epok pod względem fascynacji wzrokiem w jego kulturowym wymiarze? Czy warto zgłębić to zagadnienie, porównując teraźniejsze zjawisko wzrokocentryzmu $\mathrm{z}$ „odsłonami” owego zjawiska w epoce wczesnej nowożytności? Czy można w tym celu sięgnąć po literackie arcydzieło wszech czasów, za jakie uznaje się Hamleta? Czy w tym dramacie Szekspirowskim można odnaleźć odniesienia do świata zmysłów, a tym samym, czy Hamlet jest uzmysłowiony? Czy zatem zapoznanie się z reprezentacjami zmysłów w dramacie pozwoli na „uzmysłowienie sobie zmysłów” pod względem ich kulturowej istoty? Czy nie należałoby sięgnąć głębiej, mianowicie do postmodernistycznych adaptacji tej sztuki, z zamiarem odnalezienia w nich współczesnych wyobrażeń zmysłów, a tym samym odmiennego uzmysłowienia Hamleta? Czy w związku z tym najodpowiedniejszą adaptacją dramatu będzie adaptacja filmowa jako w pełni ucieleśniająca ideę rzeczywistości absorbującej zmysł wizualny, a więc rzeczywistości przeznaczonej głównie do wzrokowego podziwiania?

W prezentowanej książce staram się znaleźć odpowiedzi na powyższe pytania, eksponując kulturowy wymiar postrzegania zmysłowego. Różni się on od badań nad tym zjawiskiem w naukach przyrodniczych i kognitywnych przede wszystkim tym, że dostrzega w percepcji sensualnej zmienny historycznie potencjał znaczeniowy, różny od uznawanej za stałą, czysto biologiczną funkcję percepcyjną. Czym więc są zmysły - oto jest pytanie...

W Hamlecie uzmysłowionym zakładam za Marshallem McLuhanem, że „każda kultura jest pewnym porządkiem zmysłowych preferencji” (2001: 339). Bazując na powyższym stwierdzeniu, staram się rozpatrywać świat zmysłów z uwzględnieniem jego historycznej konceptualizacji. Usiłuję zrozumieć kluczowy dla cywilizacji Zachodu moment (oczywiście rozumiany niedosłownie, ponieważ przemiana nie dokonuje się $w$ historii momentalnie, a procesowo) sensorycznej transformacji paradygmatycznej, czyli przejścia od jednego porządku zmysłowego do innego. Przede wszystkim interesuje

do podkreślania dominującej roli wzroku w kulturze zachodniej. Zachęca on, by „rozważyć, jakie alternatywy dla hiperwizualności mogą znajdować się w innych sensorycznych królestwach, albo też, jakie opcje mogą powstać z połączenia zmysłów w nowych proporcjach" (2003: xii-xiii). 
mnie ów „moment”, w którym władzę w królestwie percepcyjnym bezapelacyjnie zaczął przejmować zmysł wzroku, zaś praktyki społeczne zaczęły dążyć do eksploatacji tego, co „wizualne”, w niespotykanym dawniej zakresie.

Konsekwencje przejścia od kultury, w której ludzie na co dzień wykorzystywali głównie zmysł słuchu i to na nim bazowali, do kultury, w której coraz bardziej to, co akustyczne, traciło na znaczeniu na rzecz szeroko rozumianych wizualnych przejawów rzeczywistości, wymagają także nazwania. Taka kulturowa zmiana paradygmatu, określona przeze mnie jako transformacja kultury późnoakustycznej w kulturę wczesnowizualną, przypada na renesansowe „zmagania” dwóch organów postrzegania: oka i ucha. Z jednej strony, na poziomie dosłownej funkcjonalności, te dwa zmysły rywalizują ze sobą w zakresie przydatności, jakości i częstotliwości dostarczania informacji. Z drugiej strony, warto „przyjrzeć i wsłuchać się" w metaforyczne zastosowanie oka i ucha jako nośników potężnych znaczeń symbolicznych w kulturze. Z punktu widzenia badań będących przedmiotem tej pracy, szczególnie ważny jest sensoryczny aspekt kultury wczesnonowożytnej. Jeśli zmienne preferencje wykorzystania zmysłu słuchu lub wzroku w procesie poznania umieścić w kontekście kulturowych badań nad ludzkim sensorium, to nieuniknione wydaje się starcie pomiędzy głosowością a wzrokowością, mową a pismem, praktykami słuchania a patrzenia. Szekspirowską sztuką, która być może nieświadomie podejmuje to wyzwanie, jest Hamlet. Transformacyjny charakter społeczeństwa renesansowego, niepewnego „natury" swych doznań zmysłowych, manifestuje się w tekście dramatu.

Przyjmuję, że literatura stanowi obszar, z którego wyrastają wyobrażenia kulturowych, indywidualnych i zbiorowych doświadczeń ludzkich, w tym przeżyć sensualnych. Skoro ciekawi mnie sposób reprezentowania świata zmysłów w dramacie Hamlet, bo traktuję go jako specyficzny rodzaj zapisu ludzkich doświadczeń percepcyjnych, to podobną funkcję może spełniać film, a dokładniej wybrane adaptacje analizowanej przeze mnie sztuki. Sposoby kulturowego konstruowania stanów i doświadczeń angażujących zmysły są w tym przypadku zaczerpnięte z konwencji filmowej. Ponieważ w Hamlecie uzmysłowionym koncentruję się na adaptacjach filmowych dramatu Hamlet, dlatego między literaturą a filmem pojawia się szczególna relacja. I choć język adaptacji oraz literatury jest nieprzekładalny, jeśli chodzi o możliwość komunikowania sensów, to wspólnym elementem poetyki zarówno dzieła dramatycznego, jak i filmowego, jest dosłowna zawartość tekstualna. Na tej płaszczyźnie i tekst dramatu Hamlet, i adaptacje stanowią punkt wyjścia dla zbadania kulturowych sposobów tworzenia przedstawień zmysłów. Zasygnalizowanie wspólnej płaszczyzny jest celowe ze względu na przeprowadzoną przeze mnie analizę porównawczą konwencji literackiej i filmowej, ze wskazaniem na różnice w obrazowaniu zmysłów w obu dziedzinach artystycznych. Tekst dramatu Hamlet i tekst adaptacji Hamleta byłyby więc jedynie punktem startowym dla dalszych poszukiwań form komunikowania znaczeń. 
Dzięki takiemu spojrzeniu możliwe jest wydobycie kontrastu w sposobie ukazywania kobiecego doświadczenia bohaterek dramatu: Ofelii i Gertrudy - w tekście i na ekranie. Obrazowanie doświadczeń zmysłowych ma na celu zwrócenie uwagi, a zarazem uwrażliwienie na obecne w Hamlecie i jego filmowych adaptacjach postrzeganie właściwe każdej z płci społeczno-kulturowej. Literackie i filmowe reprezentacje zmysłu wzroku i słuchu kryją się w sposobie ukazania widzenia i słyszenia na przykładzie bohaterów dramatu. Istotne z punktu widzenia tematyki podjętej w tej książce jest uwzględnienie specyfiki kobiecych doświadczeń, które można skonfrontować z przedstawieniami męskich praktyk wykorzystywania zmysłów w kulturze. Z wielu funkcji kulturowych spełnianych przez zmysły i różnie wykorzystywanych w zależności od płci warto wymienić takie jak: warunkowanie poznania, stanowienie narzędzi władzy czy też źródeł przeżywanych doznań. Postrzeganie zmysłowe zostanie ukazane jako zmienny w czasie konstrukt kulturowy, zaś jego reprezentacje można odnaleźć w tekstach literackich i ich pozaliterackich kontekstach. Takie podejście do postrzegania pozwala na zestawienie kulturotwórczej roli zmysłów w okresie renesansu, w którym powstała sztuka Szekspira, z funkcjami zmysłów w czasach współczesnych, kiedy pojawiły się filmowe adaptacje dramatu.

Prowadzenie badań nad znaczeniem zmysłów i doświadczeń sensualnych w kulturze zachodniej w różnych okresach, przy wykorzystaniu do tych badań dzieła Szekspira, jest istotne z punktu widzenia szekspirologii, zmierzającej w kierunku dywersyfikacji i ku rozszerzeniu optyki badawczej ${ }^{4}$. W dodatku należy zwrócić uwagę na problematykę zmysłów w kulturze, a ponadto zaznaczyć, że, choć przyciąga ona uwagę różnych dyscyplin, zarówno w Polsce, jak i na świecie, posiada własną historię i stanowi jeden z dylematów filozoficznych, to jednak trudno mówić o zgłębieniu świata zmysłów w ujęciu kulturowym. W ramach szekspirologii jest to w miarę nowe zagadnienie badawcze. Warto zatem podjąć wątek reprezentacji doświadczeń zmysłowych w różnych dziełach literackich i ich pozaliterackich kontekstach, rozpoczynając od „Mony Lizy” literatury, czyli Hamleta ${ }^{5}$.

\footnotetext{
${ }^{4}$ Dwaj badacze, Lowell Gallagher i Shankar Raman, są redaktorami pracy Knowing Shakespeare: Senses, Embodiment, and Cognition, która ukazała się w grudniu 2010 roku nakładem wydawnictwa Palgrave Macmillan. Tom zawiera eseje poświęcone między innymi percepcji sensorycznej w dziełach Szekspira. Ponadto Gallagher i Raman przewodniczyli seminarium „Con-Founding the Senses in Shakespeare”, które odbyło się w ramach 31. corocznego spotkania Shakespeare Association of America (10-12 kwietnia 2003 roku) (http://www.shakespeareassociation.org). Jako inny przykład zainteresowania zmysłami przez badaczy dzieł Szekspira może posłużyć sesja konferencyjna „Shakespeare and the Senses of Perception”, która miała miejsce podczas 15. corocznej konferencji zorganizowanej przez The Arizona Center for Medieval and Renaissance Studies, poświęconej zmysłom w średniowieczu i renesansie (http:// www.acmrs.org).

${ }^{5}$ Porównanie Hamleta do Mony Lizy zaproponował T. S. Eliot, podkreślając enigmatyczny charakter dramatu (1975: 47).
} 
Podjęcie problematyki reprezentacji zmysłów w dramacie oraz w filmie wymaga zastosowania specyficznych narzędzi metodologicznych. Metodologia badań wpisuje się w szeroko pojęte badania kulturowe. W analizie porównawczej reprezentacji doświadczeń sensualnych, rozumianych jako doświadczenia kulturowe, sięgam po pojęcia badawcze z takich subdyscyplin, jak bardziej znana antropologia literacka czy też dopiero rozwijająca się antropologia zmysłów. Dodatkowo niezwykle pomocne okazuje się odwołanie do metodologii studiów feministycznych i genderowych. Zatem metodologiczne zabiegi badawcze sprowadzają się przede wszystkim do wykorzystania interdyscyplinarnych powiązań między feminizmem, gender studies i antropologią kulturową. Każda z tych orientacji wnosi właściwe sobie założenia teoretyczne, przyczyniające się do tego, że proces interpretacji zyskuje więcej, niż gdybym wykorzystała tylko jedną perspektywę poznawczą.

Perspektywa feministyczno-genderowa dostarcza takich kategorii badawczych, które pozwalają na uwzględnienie historycznych i społecznych uwarunkowań płci, i umożliwia wydobycie kontrastu w sposobie ukazywania kobiecego i męskiego doświadczenia angażującego zmysły w Hamlecie. Podstawową kategorią, którą wyróżniam w niniejszej książce, jest sensoryczność doświadczeń męskich i kobiecych, odwołująca się do klasycznego w teorii feministycznych binarnego podziału na męskość i kobiecość. Analiza odmienności doświadczeń generowanych przez zmysły to zwłaszcza zestawienie doznań percepcyjnych kobiecych i męskich.

Jednocześnie staram się cały czas uwzględniać to, że, podobnie jak upłciowionym ciałom przypisuje się pewne atrybuty, symbolikę i wartości, tak samo występuje asymetria $\mathrm{w}$ wykorzystaniu zmysłów przez daną płeć. Stawiam tezę, że oznakowana sensorycznie płeć społeczno-kulturowa posiada specyficzny kod odnoszący się do sposobów, w jakie kobiety i mężczyźni wykorzystują zdolności percepcyjne w życiu społecznym. W zależności od płci występuje określony repertuar zachowań, gestów i sposobów posługiwania się własnymi zmysłami. Świat sensoryczny przybiera formę relacji międzyludzkich przedstawionych w odmiennych materiałach kulturowych. Poznanie kulturowych aspektów zmysłów, ich społecznych funkcji oraz wyodrębnienie zmysłu dominującego w kulturze danego okresu umożliwia odwoływanie się do zagadnień nurtu antropologicznego, czyli do antropologii zmysłów. Narzędzia antropologii literackiej i antropologii wizualnej stwarzają możliwość uwzględnienia reprezentacji zmysłów w tekstach kultury, czyli w dramacie Hamlet oraz jego filmowych adaptacjach.

Pragnę podkreślić, że korzystam też z założeń nowego historycyzmu, między innymi takich, że proces interpretowania dzieła odbywa się pod wpływem dawnych znaczeń i przez interakcję z wcześniejszymi badaniami. Moja interpretacja współczesnych adaptacji Hamleta jest mocno osadzona w tekście oryginału, który w miarę funkcjonowania w odmiennym kontek- 
ście „wchłania” dotychczasowe znaczenia. Skoro adaptacja filmowa to dzieło sięgające do innego utworu, zatem samo nie posiada jednego źródła, zaś jego niejednorodna genetycznie struktura składa się z kolekcji zapożyczeń reprezentacji na strukturę o skomplikowanym rodowodzie.

W Hamlecie uzmysłowionym w interdyscyplinarny sposób staram się przyjrzeć reprezentacjom zmysłów zarówno w samym tekście Hamleta, jak i w wybranych adaptacjach filmowych. Do pewnego stopnia postępuję wbrew nawoływaniom Horace'a Howarda Furnessa, jednego z dziewiętnastowiecznych badaczy i redaktorów dzieł Szekspira, który w jednym ze swoich przemówień z 1908 roku zwrócił się do swoich uczonych kolegów: „Pozwólcie mi usilnie prosić, błagać, zaklinać i upraszać was, byście nie pisali więcej prac o Hamlecie". Ten błagalny ton był spowodowany niebywałą liczbą publikacji na temat dramatu Hamlet. Jak wskazują statystyki publikacji, opracowywanych corocznie w ramach World Shakespeare Bibliography, niesłabnące zainteresowanie Hamletem sprawia, że od początku XX wieku, każdego roku przybywa średnio czterysta publikacji poświęconych tej sztuce. Spośród nich znaczna część zawiera krytykę literacką, wykorzystującą rozmaite podejścia badawcze. Obejmują one nie tylko nurty mocno osadzone w teorii literatury, jak na przykład poststrukturalizm i psychoanaliza, lecz także nieco nowsze metody analityczno-interpretacyjne, do których należą między innymi: feminizm, postmodernizm czy materializm.

Na podkreślenie zasługuje fakt, że praktycznie każda ze szkół badawczych, występujących na polu literaturoznawczym, po pewnym czasie obejmuje swym zasięgiem sztuki angielskiego dramaturga. Za sztandarowy przykład może posłużyć freudowska koncepcja kompleksu Edypa, zainspirowana Hamletem, która stanowi jeden z istotniejszych elementów psychoanalizy. W dodatku każdy z nurtów przejawia także skłonność do ekspansywności i ewolucyjności, stąd nieustanne rozszerzanie zasięgu wpływu oraz dążenie do przeobrażeń i doskonalenia. W niniejszej książce korzystam z powyższych „skłonności”, zakładając możliwość zainteresowania odbiorców interpretacją dramatu Szekspira ukierunkowaną na Hamleta uzmysłowionego ${ }^{6}$.

\footnotetext{
${ }^{6}$ Nieprzypadkowo posługuję się w pracy jednym tłumaczeniem Hamleta, z 1953 roku, dokonanym przez Władysława Tarnawskiego; uznałam je bowiem za najwierniejsze pod względem przekładu wyrażeń percepcyjnych na język polski. Po porównaniu tego tłumaczenia z dwoma innymi przekładami (oddalonymi w czasie), Józefa Paszkowskiego (1862) i Stanisława Barańczaka (1990), okazało się, że słowa takie, jak „eyes” i „ears” - które występują w wersji angielskiej - zostały przez tłumacza w odpowiednim kontekście przełożone na język polski. U pozostałych tłumaczy niektóre spośród tych słów zostały zastąpione innymi wyrażeniami, przez co przekład Tarnawskiego wydaje się bardziej dokładny i przydatny dla moich badań. Za wyjściowy dla analiz tekst dramatu przyjęłam wydanie Hamleta z serii The Arden Shakespeare, pod redakcją Anny Thompson i Neila Taylora z 2006 roku (wybór tego wydania uzasadniam w dalszej części pracy). Dodatkowo w poszczególnych rozdziałach występują liczne tłumaczenia fragmentów prac anglojęzycznych, których dokonałam na potrzeby książki. Natomiast wszystkie tytuły tych prac pozostawiłam w oryginalnym brzmieniu.
} 
Rozdział 1

\section{Kulturowa architektura zmysłów}

\section{Percepcyjne ekscesy - rzecz o niepokornej teorii naukowej}

Zmysły są wyraźnie potrzebne kulturze „do życia”, w istocie będąc w niej obecne na wielu płaszczyznach: symbolicznej, językowej czy filozoficznej, by wymienić tylko kilka z nich. De facto ta kulturowa obecność zmysłów nie mogła ujść uwagi badaczy zajmujących się rejestracją i interpretacją różnych zachowań, zjawisk, modeli oraz paradygmatów kulturowych. Dzięki coraz powszechniejszemu przekraczaniu granic w nauce obszar badań kulturowych ewidentnie ulega ciągłej ekspansji. Może o tym świadczyć fakt stopniowego włączania w owo terytorium nowych przedmiotów badań, takich jak: język i teksty kulturowe, ciało ludzkie i cielesność, obrazy i wizerunki kulturowe, czy też zmysły. Człowiek - dysponent własnego sensorium - ma także potrzebę uzmysłowienia sobie własnego społeczno-kulturowego znaczenia. Stąd, być może, „percepcyjne ekscesy”, jakich dopuszcza się w ramach studiów nad zmysłami. Burząc stare mury, a nawet likwidując fundamenty dawnych teorii, stawia nowe - niejednokrotnie zmieniając całe zaplecze architektoniczne.

Pomocne w owych „przemianach otoczenia” stały się tzw. zwroty badawcze, które $w$ zależności od przedmiotu badań określa się jako: zwrot lingwistyczny (linguistic turn), zwrot korporalny (corporeal turn), zwrot ikoniczny (pictorial turn) oraz zwrot sensoryczny (sensory turn). Jak podaje David Howes - czołowy współczesny badacz zmysłów - począwszy od lat sześćdziesiątych dokonał się znaczący dla studiów humanistycznych i nauk społecznych przewrót językowy, zainspirowany lingwistyką Ferdinanda de Saussure'a. Wprowadził on paradygmat kulturowy oparty na analizie zjawisk społecznych i utrzymujący, że kultura jest strukturalnie podobna do języka, a wszelka interpretacja powinna opierać się na podstawowych założeniach lingwistycznych (Howes, Architecture of the Senses). Sformułowanie „świat jako tekst" stanowiło hasło przewodnie wśród zwolenników podejścia lingwistycznego aż do końca lat siedemdziesiątych XX wieku (Howes, 2005: 1). Lata osiemdziesiąte przyniosły zmianę w postaci nowego przewrotu, skoncentrowanego na roli obrazu i przekazu wizualnego w kulturze. 
„Przesunięcie” od słowa w stronę wizerunku spowodowało nie tylko porzucenie i opuszczenie „imperium znaków” na rzecz triumfalnego wkroczenia w nowy obrazkowy wymiar kultury, ale też uświadomiło, jak szybko w ramach badań kulturowych jeden paradygmat może zdetronizować poprzedni.

Gdy na początku lat dziewięćdziesiątych stało się jasne, że zwrot ku cielesności zdominuje studia kulturowe, zwrot obrazkowy musiał ustąpić miejsca kolejnej zmianie, a mianowicie przewrotowi korporalnemu. Koncepcja „ucieleśnienia” zaczęła pojawiać się w większości tekstów dotyczących analiz zjawisk kulturowych. Choć zagadnienia ciała i cielesności nie należały już tylko do naukowców poruszających się w obszarze nauk przyrodniczych, medycyny, a nawet filozofii, to w analizach kulturowych brakowało relacyjnego podejścia do cielesnych zdolności człowieka. We wprowadzeniu do studiów o zmysłach autorzy komentują podejście relacyjne, twierdząc, że „zburzy [ono] założenie o jedności ciała (które po prostu zastąpiło modernistyczne założenie o jedności podmiotu) poprzez podkreślenie różnych omówień zmysłów w odmiennym czasie i miejscu, oraz poprzez uwypuklenie wielości form ludzkiej zmysłowości" (Bull et. all, 2006: 6). Ponadto Howes utrzymuje, że na przełomie XX i XXI wieku zmysły pojawiły się w centrum zainteresowania studiów kulturowych na fali zwrotów badawczych w naukach społecznych i humanistyce. Badacz zwraca uwagę na charakter kolejnego zwrotu badawczego, a nawet rewolucji sensorycznej, która bazując na poprzednich podejściach, jednocześnie zmierza ku naprawieniu ich niedociągnięć. Korekta miałaby polegać na usunięciu pewnych „nadmiarów”. W przypadku zwrotu lingwistycznego, na przykład, chodzi o zmniejszenie przesadnego eksploatowania słowa ( $\mathrm{w}$ piśmie i mowie) oraz o powstrzymanie przesadnego wizualizmu i koncentracji jedynie na obrazach, dominujących w zwrocie ikonicznym (Howes, 2006: 114).

Howes przypomina, że zwrot korporalny lat dziewięćdziesiątych przywrócił zagadnienie ciała i cielesności do analiz antropologicznych i jednocześnie właśnie z tego przewrotu wyrosła rewolucja sensoryczna. Metodologia badań nad zmysłami jest zakorzeniona w „zaangażowanych doznaniach”, nie zaś w „obserwacji”, co prowadzi do odejścia od dokonywania pomiarów na rzecz skoncentrowania na rozumieniu znaczenia zmysłów i wykorzystaniu ich w określonych kontekstach kulturowych (Howes, 2006: 121). Pojmowanie kultur jako struktur „ucieleśniających różne sposoby odczuwania czy też »techniki zmysłowe«, prowadzi do „opisu tego, co »socjo-logiczne« i dostarczające informacji na temat sposobu, w jaki członkowie danej kultury rozróżniają, wartościują, tworzą powiązania i połączenia pomiędzy zmysłami w ich życiu codziennym” (122)7. Według Edwarda Halla: „Różny nacisk, kła-

\footnotetext{
${ }^{7}$ Kulturowe badania nad zmysłami w ramach studiów sensorycznych zostały zainicjowane i następnie prowadzone w formie projektów przez zespół badaczy o nazwie „The Concordia Sensora Research Team” („CONSERT”) w 1988 roku. Zespół pracuje na Uniwersyte-
} 
dziony w stworzonych przez ludzi kulturach na wzrok, słuch i węch, doprowadził do zupełnie różnego postrzegania przestrzeni i zupełnie różnych relacji między jednostkami" (2003: 57).

Do czego zatem prowadzą wspomniane „ekscesy percepcyjne” dokonywane na polu badań nad zmysłami? Z jednej strony chodzi zapewne o „włożenie kulturowych okularów”, które mają usprawnić dotychczasowe postrzeganie (teoretyzowanie) świata zmysłów, dlatego na tym etapie celem studiów sensorycznych (sensory studies) jest wprowadzenie postrzegania zmysłowego jako konstruktu społecznego w obszar szeroko rozumianych badań kulturowych. Z drugiej strony takie "naukowe wybryki” służą przełamaniu bezrefleksyjnego i uniwersalnego traktowania ludzkiego sensorium. Przeprowadzenie egzorcyzmów na tym polu łączy się z wygnaniem demona podpowiadającego, że każda kultura w takim samym stopniu wykorzystuje zmysł smaku, węchu, dotyku, słuchu albo wzroku, czy też, że przypisuje im te same funkcje bez względu na szerokość geograficzną. 0 zmysłach teoretyzuje się, traktując je jak "kanały” w tworzeniu relacji pomiędzy umysłem i ciałem, myślą i rzeczą, „ja” i środowiskiem (zarówno fizycznym, jak i społecznym) (Howes, 2006: 122). Jeśli zaś przyjąć za autorami „Introducing Sensory Studies", że „[z]mysły są wszędzie” (Bull et. all, 5), to okaże się, iż zbyt długo ta sfera ludzkiej egzystencji pozostawała niezbadana. Według tych samych badaczy: „To, co percepcyjne, jest kulturowe i polityczne, nie jest zaś po prostu (jak ujęliby to psychologowie i neurobiolodzy) kwestią procesów poznawczych czy mechanizmów neurobiologicznych zachodzących $w$ indywidualnym podmiocie" ([podkreślenie autorów], 5).

\section{„Nie taki zmysł naturalny, jak go maluja"}

Nadal żywe jest przekonanie o „nieprzepuszczalności” granic pomiędzy tym, co kulturowe, a tym, co naturalne. Kulturowa perspektywa zorientowana na zmysły, która „zrywa z apriorycznym założeniem »naturalności« postrze-

cie Concordia w Kanadzie w ramach Wydziału Socjologii i Antropologii (The Departament of Sociology and Anthropology). Wśród zespołu badaczy należy wymienić cytowanych w niniejszej pracy: Davida Howesa, Constance Classen, Stevena Connora oraz Michaela Bulla (http:// alcor.concordia.ca).

8 "Introducing Sensory Studies” stanowi wstęp do pierwszego numeru kwartalnika The Senses and Society, poświęconego badaniom nad percepcją zmysłową w kulturze. Czasopismo wydawane jest od 2006 roku przez Berg Publisher, który jest też wydawcą serii prac z zakresu studiów sensorycznych - „The Sensory Formations”. Na serię składają się następujace prace: The Auditory Culture Reader (2003), Empire of the Senses: The Sensual Culture Reader (2004), The Taste Culture Reader: The Experience of Food and Drink (2005), The Book of Touch (2005), The Smell Culture Reader (2006), Visual Sense: A Cultural Reader (2008) oraz The Sixth Sense Reader (2009). 
gania zmysłowego" (Jütte, 2005: 8), umożliwia zbadanie znaczeń związanych ze zdolnościami sensorycznymi człowieka, istotnych dla ujęcia antropologicznego. Nie przez przypadek jedną z najintensywniej rozwijających się subdyscyplin nauki, która ogniskuje swe zainteresowanie wokół sensów, symboliki i funkcji zmysłów w kulturze, jest antropologia zmysłów. W analogiczny sposób do propozycji badawczych antropologii ciała (posiadającej już ugruntowaną pozycję jako subdyscyplina naukowa), która wysunęła postulat „powrotu do ciała", także formująca się dopiero antropologia zmysłów zaproponowała zainteresowanie postrzeganiem zmysłami. Takie stwierdzenie może sugerować, że w przeszłości istniała nauka zajmująca się zmysłami. Otóż z pewnością należy stwierdzić, że w każdej epoce można wyodrębnić materiały kulturowe (na przykład teksty literackie, traktaty medyczne), które rozróżniają ludzkie zmysły i w odmienny sposób je klasyfikują, między innymi poprzez zbudowanie stosownej do danego modelu kultury hierarchii zmysłów. Począwszy od starożytnych prób uporządkowania i wyznaczenia gradacji zmysłów, na każdym etapie rozwoju człowieka, zmysły budziły fascynację i bojaźń. Jednak dopiero współczesne badania kulturowe podjęły próbę ich „wskrzeszenia” w formie antropologicznego ujęcia ludzkiego aparatu percepcyjnego.

Podejście antropologizujące stawia sobie za cel ukazanie historii zmysłów, która uwzględniałaby odmienne modele sensoryczne danej kultury, pojmowane jako dynamiczne i rozwijające się wzorce oraz wartości związane ze zmysłami. Koncepcję modelu sensorycznego wprowadziła Constance Classen w eseju „Foundations for an Anthropology of the Senses”:

Kiedy badamy znaczenia kojarzone z różnymi zdolnościami i doznaniami płynącymi od zmysłów w odmiennych kulturach, odnajdujemy bogactwo potężnej symboliki sensorycznej. Wzrok może być powiązany z rozumem albo z czarami, smak może być użyty jako metafora estetycznej dyskryminacji lub doświadczenia seksualnego, zapach może oznaczać świętość lub grzech, siłę polityczną albo społeczne wykluczenie. Razem te sensoryczne znaczenia i wartości kształtują model sensoryczny, podtrzymywany przez społeczeństwo. Zgodnie z nim, członkowie tego społeczeństwa „rozumieją" świat, przekładają postrzeganie zmysłami oraz koncepcje na określony „obraz świata”. Istnieje prawdopodobieństwo pojawienia się społecznych wyzwań dla tego modelu oraz ludzi i grup mających odmienne zdanie co do wartości sensorycznych, jednak ten model dostarcza podstawowego percepcyjnego paradygmatu, który powinno się przyjąć lub odrzucić ([podkreślenie autorki] 1997: 402).

Antropologia zmysłów posługuje się pojęciem "model sensoryczny" w celu określenia dominujących obyczajów i wartości związanych ze zmysłami w kulturze. Nie chodzi tu jednak o model, który byłby jednakowo podzielany i wspierany przez wszystkich w danym społeczeństwie. Na przykładzie „zachodniego wizualizmu" widoczne staje się, że nie każdy uczestnik tej kultury jednakowo preferuje wyobraźnię oraz myślenie za pomocą obrazów i wizerunków. To raczej wizualne media i metafory językowe wpływają na dominujące wartości i praktyki kulturowe w ramach tego modelu (Howes, 2008: 449-450). 
Zachwianiem równowagi w przypadku poszczególnych modeli sensorycznych mogą być alternatywne sposoby oglądu świata, o których pisze Classen:

\begin{abstract}
Wartości sensoryczne propagowane przez dominującą grupę społeczną są zwykle, w mniejszym bądź w większym stopniu, internalizowane przez wszystkie grupy w społeczeństwie. Na przykład reprezentanci klasy robotniczej będą przekonani, że bez względu na to, ile razy się umyją, albo jakich perfum użyją, i tak pozostaną niewystarczająco czyści i pachnący w porównaniu z przedstawicielami klasy wyższej. Członkowie marginalizowanych grup mogą podważać sensoryczne wartości i wysuwać alternatywne schematy, które uwydatnią kontrast pomiędzy „czystymi moralnie” robotnikami a „brudnymi” bogaczami (cyt. za Howes, 2008: 450).
\end{abstract}

Pojawienie się wyżej wymienionych, nieszablonowych rozwiązań percepcyjnych, stosowanych np. przez członków niższej klasy, pozwala nie tylko na zaprezentowanie odmiennej sensorycznej wizji świata, ale także na podważenie dominującego paradygmatu percepcyjnego. Jest to rodzaj kulturowej wywrotowości stosowanej przez grupy marginalizowane w stosunku do panującego modelu sensorycznego.

By zrozumieć model sensoryczny jakiejś kultury, należy skoncentrować się na badaniach dotyczących współdziałania wzroku, słuchu, węchu, smaku i dotyku. Nie wystarczy rozpatrzenie jednego, dominującego nad innymi zmysłu (Howes, 2005: 161). Każdy ze zmysłów dostarcza innych doznań osobistych, ale też w szczególny sposób wpływa na relacje społeczne. Ponieważ relacje sensoryczne są jednocześnie relacjami społecznymi (161), mają one wpływ na rozmaite kategoryzacje, podziały oraz segregacje i wykluczenia wewnątrz danej społeczności. 0 sensorycznej kodyfikacji ras można dowiedzieć się, na przykład, na podstawie koncepcji podziału ras ze względu na kulturową hierarchię zmysłów. Jest to dziewiętnastowieczna teoria antropologiczna autorstwa Lorenza Okena, który uznał, że Europejczyka charakteryzuje oko (eye-men), Azjatę - ucho (ear-men), Australijczyka - język (tongue-men), rdzennego Amerykanina - nos (nose-men), zaś Afrykańczyka - skóra (skin-men). W owej piramidzie rasowej najwyżej sytuował się Europejczyk, powiązany z najbardziej cenionym ze zmysłów, czyli wzrokiem, a na samym dole znalazł się Afrykańczyk, jako rasa najniższa, skojarzona ze zmysłem dotyku (Classen, 1997: 405). W pracy Sensory History (2007) Mark M. Smith przytacza dziewiętnastowieczny pogląd dotyczący wyższości wzroku - zmysłu utożsamianego z intelektem, dystansem i prawdą - nad dotykiem, uznawanym za zmysł powiązany z doznaniami cielesnymi, niecywilizowanymi i pozbawionymi obiektywizmu (2007: 24). Hierarchia ras, która powstała na podstawie skojarzenia najniższego ze zmysłów z mieszkańcami Afryki, miała na celu przypisanie im cech negatywnych i pogardzanych przez „ucywilizowanego" Europejczyka9.

${ }^{9}$ Szerzej na ten temat Smith pisze w pracy How Race Is Made: Slavery, Segregation, and the Senses (2006). 
Innym przykładem na wykorzystanie jednego ze zmysłów w celu scharakteryzowania i zaklasyfikowania danej grupy społecznej był podział klas według zapachu. Smith powołuje się na stwierdzenie Georga Orwella, który reprezentuje opinię, że w kulturze zachodniej „tajemnica podziału na klasy” tkwi w prostym zdaniu: „Niższa klasa cuchnie” (cyt. za Smith, 2007: 66). Wręcz „wyczuwalny" jest w tym sformułowaniu sposób dyskryminowania klasy niższej poprzez uznanie jej za odznaczającą się brzydką wonią. Oddzielenie od siebie klas za pomocą węchu ustanowiło także przekonanie o większej wrażliwości na zapachy wśród klasy wyższej. Klasą upośledzoną okazali się robotnicy, którzy zaakceptowali przykry zapach towarzyszący ich ciężkiej pracy, często powodowany przez niehigieniczny tryb życia. Wartości, jakie przypisano zapachowi i zmysłowi węchu, stanowiły o przynależeniu do danej klasy społecznej, przyczyniając się do stygmatyzacji robotników jako cuchnących i tym samym gorszych od swoich pracodawców. Smith posługuje się stwierdzeniami „zapach klasy” i „klasa zapachu”, które stały się wyznacznikami przynależności klasowej i kulturowo rozpoznawanego rodzaju woni wydzielanej przez ludzi. Autor Sensory History podaje za Howesem, że „[ś]wiadomość zapachu, jaki wydziela jednostka, pozwoliła na stworzenie konstrukcji olfaktorycznych innych" (2007: 67). Jak pokazują powyższe przykłady, kulturowe badanie percepcji zmysłowej pozwala na rozpoznanie powiązań pomiędzy zmysłami a innymi kulturowymi konstruktami, takimi jak rasa, klasa czy gender.

Można posłużyć się w tym miejscu słowami Howesa, który wyraził następującą opinię na temat zadania, jakie stoi przed badaczami zmysłów: „Sensorycznie rzecz ujmując, przeszłość to »terra incognita« i należy ją odkrywać, mając zmysły szeroko otwarte" ([podkreślenie autora] 2008: 450). Badacz uważa, że zwrócenie naszej uwagi na określone wrażenia pochodzące od zmysłów nie może być uznane za główny powód zmian, które dotykają dany zmysł i stają się przyczyną utraty jego znaczenia na rzecz innego. Howes przyznaje, że każdy człowiek nadaje priorytet pewnym informacjom docierającym doń ze świata zmysłów i tym (informacjom) zapośredniczonym przez dany zmysł. Jednak tym, co uznaje za istotniejsze w owym procesie, jest aktywne tworzenie środowisk sensorycznych przez ich mieszkańców. Zatem nie chodzi tu jedynie o bierne doświadczanie bycia w środowisku sensualnym, dostarczającym więcej takich wrażeń, które dana kultura uznaje za znaczące, zaś mniej - pozostałych wrażeń. To raczej światy sensoryczne są kształtowane przez zamieszkujących je ludzi.

Jako przykład Howes podaje wzrost znaczenia wizualności w czasach nowożytnych, spowodowany przez złożoność procesów naukowych, technologicznych, społecznych i ekonomicznych. Ważniejszy od wzmożonej koncentracji uwagi na zjawiskach wzrokowych okazał się wieloaspektowy proces wyłaniania się kolejnych fragmentów świata przed ludzkimi oczami. Wynalezienie nowych przyrządów optycznych, rozwój praktyk medycznych oraz 
rozpowszechnienie wystaw i występów artystycznych spowodowały, że nieznane dotychczas fragmenty świata ukazały się oczom ludzi ery nowożytnej. Zatem uczestnictwo bierne i czynne to dwa wymiary: bycia i tworzenia środowiska sensorycznego. W tamtym czasie przekształciły one świat w spektakl wizualny (Howes, 2008: 448). Przyjęcie perspektywy skoncentrowanej na zmysłach wymaga zatem uwzględnienia decydującego wpływu jednostek na ich środowisko sensoryczne, a także faktu, że niezależnie od tego wpływu, jednostki są zdane na odbiór docierających do nich wrażeń zmysłowych.

Jeśli przyjąć za badaczem, że postawienie sfery percepcyjnej w centrum zainteresowania naukowego wcale nie oznacza „postradania zmysłów”, lecz „odzyskanie zdrowego rozsądku” (Howes, 2005: 7), to okaże się, iż poznawanie świata sensorycznego $w$ jego kulturowym wymiarze jest jednym z większych oraz w pełni racjonalnych wyzwań stojących przez badaczami kultur. Analizy takie mogą być niezwykle użyteczne dla studiów genderowych. Można pokusić się o stwierdzenie, że żadna inna dyscyplina naukowa nie jest tak bardzo ukierunkowana na formacje kulturowe, w tym przede wszystkim na konstrukty kulturowe (na przykład płeć czy ciało), jak właśnie obszar badań na temat płci. Dlatego bez wahania można sformułować następujący wniosek: ludzkie zmysły podlegają analogicznym analizom jak cielesność czy seksualność i stanowią kolejne pole badań, które w żaden sposób nie jest obciążone szkodliwą dla wszelkich badań ahistorycznością i apolitycznością.

Rewolucja sensoryczna z pewnością spowoduje zmiany na gruncie studiów genderowych, przyczyniając się do zwrócenia uwagi na zmysły jako zmienny w czasie i miejscu konstrukt kulturowy. Classen zwraca uwagę, że „[s]posób, w jaki dane społeczeństwo odczuwa zmysłami, to sposób, w jaki rozumuje” (Howes, 2005: 161). Swego rodzaju „myślenie zmysłami” uwidacznia się na poziomie językowym, będącym podstawowym wyznacznikiem ludzkiego pojmowania. Równie istotna pozostaje mowa ciała, czyli sposób posługiwania się zmysłami w życiu codziennym, oraz związane z tym normy i zwyczaje kulturowe. To, jak człowiek wykorzystuje swój wzrok, słuch, dotyk, węch i smak, decyduje o jego umiejętności posługiwania się niewerbalnym kodem sensualnym, bez znajomości którego może zostać uznany za obcego - osobnika spoza danej kultury. Dla przykładu, w zachodnim kręgu kulturowym przyjmuje się, że kontakt dotykowy jest sferą intymną, która dla potrzeb komunikacji międzyludzkiej stosuje określone gesty, niejako wykluczone poza tą sferą. Należy do niej między innymi gest uściśnięcia dłoni na powitanie i pożegnanie czy też przypieczętowanie zawarcia umowy. Rzadko zdarza się, by osoby sobie nieznane lub słabo znane wykorzystywały dotyk w kontakcie między sobą. Oczywiście jest to uogólnienie i nie należy traktować tego jak wyznacznik relacji dotykowych na Zachodzie ${ }^{10}$.

${ }^{10}$ Bogactwo praktyk i zachowań percepcyjnych w kulturze zachodniej jest tak ogromne, że zarówno każdy kraj, jak i jego regiony, posiada urozmaicony repertuar zachowań w zakresie 
Sensoryczność doświadczeń męskich i kobiecych to w przypadku badań uwzględniających płeć kulturową istotna kwestia, która prowadzi do podjęcia problematyki znaczenia owego doświadczenia dla każdej z nich. Analiza odmienności doświadczeń generowanych przez zmysły umożliwi zestawienie doznań związanych z postrzeganiem przez każdą z płci i jednocześnie uświadomi, że podobnie jak upłciowionym ciałom przypisuje się pewne atrybuty, symbolikę i wartości, tak samo występują różnice/nierówności w wykorzystaniu zmysłów przez daną płeć. Sensorycznie oznakowana płeć społeczno-kulturowa posiada specyficzny kod odnoszący się do sposobów, w jakie kobiety i mężczyźni wykorzystują zdolności percepcyjne w życiu społecznym. Skoro w zależności od płci występuje określony repertuar zachowań, gestów i sposobów posługiwania się własnymi zmysłami, to zasadne wydaje się analizowanie świata sensorycznego z punktu widzenia relacji międzyludzkich.

Według Halla „[k]ażda kultura tworzy swój własny świat percepcyjny” (1986: xvii). Pewne wzorce zachowań kulturowych klasyfikuje się jako męskie, inne jako żeńskie, przy czym każdy z tych wzorców podlega dodatkowemu wartościowaniu. Na przykład sposoby patrzenia, czyli sposoby kontaktu wzrokowego, są nacechowane genderowo. W kulturze Zachodu przyjmuje się stereotypowe założenie o aktywnej postawie percepcyjnej mężczyzn i biernej - kobiet. Jeśli odnieść ten podział do tradycyjnych praktyk wzrokowych, wówczas okaże się, że mężczyzna "poluje” wzrokiem w niemalże nieograniczony sposób, nie mając oporów przed bezpośrednim spojrzeniem w oczy, i tym samym pokazaniem swojej dominującej pozycji społecznej. Z kolei kobiety są mniej swobodne, jeśli chodzi o wykorzystanie wzroku, co przekłada się na mniej śmiałe nawiązywanie kontaktów wzrokowych czy też skłonność do opuszczania oczu w sytuacji kontaktu wzrokowego z mężczyzną. Praktyka ta, zakorzeniona w wielowiekowym przekonaniu o ekspansywnej roli mężczyzny w zachodnim kręgu kulturowym, jest nadal spotykana w życiu codziennym, choć w znacznie mniejszym stopniu.

Doświadczenie sensualne to jedna ze sfer ludzkiej egzystencji, w pełni niewyrażalnych. Przedstawienie $\mathrm{w}$ formie reprezentacji jakiegokolwiek doznania sensualnego, czyli subiektywnego sposobu postrzegania rzeczywistości, skazane jest na nieokreśloność i nieprecyzyjność. I choć z jednej strony, nieuchwytne w swej naturze, zmysły „zaprogramowane - wiedzą, jak działać” od strony biologicznej, to z drugiej strony - „wiedzą” także, dzięki kulturze, jak powinny w tym wymiarze funkcjonować. 0 sposobach percypowania i wartościach im przypisywanych przez społeczeństwo wczesnonowożytne

wykorzystania zmysłów. Nie jest jednak celem niniejszej pracy omawianie niuansów dotyczących owych praktyk. W wielu miejscach nieuniknione jest posługiwanie się zbiorowymi wyobrażeniami na temat zmysłów. Wynikają one ze stosowania zbliżonego systemu kodowania zachowań ludzkich, dzięki którym wiele kultur percepcyjnych, o cechach indywidualnych, może współistnieć pod mianem kultury percepcyjnej Zachodu. 
informują między innymi takie materiały kulturowe, jak: rozprawy filozoficzne, prace z zakresu medycyny i dzieła literackie. Uzupełnione o dzieła sztuki, stają się one podstawą do interpretacji życia sensorycznego ludzi poprzednich epok. Słuszna wydaje się w tym miejscu uwaga Roberta Jütte, autora The History of the Senses: From Antiquity to Cyberspace (2005), który jest zdania, że: „Ktokolwiek podejmuje się badać materialny świat przeszłości i teraźniejszości, napotyka nieprzebyty gąszcz uparcie utrzymujących się wyobrażeń, metafor, motywów i reprezentacji. Wiele z nich przynależy do długiej tradycji, będąc ponownie przetwarzanymi i powtórnie wykorzystywanymi" (8). Obecność owych przedstawień, obrazów i toposów w filozofii, sztuce, medycynie i literaturze sprawia, że informacje na temat życia zmysłowego z przeszłości docierają do teraźniejszości i pozwalają na różnorodne zabiegi hermeneutyczne.

\section{Wybór między „dobra" a „złą" wersją „Hamleta”}

Leah S. Marcus w pierwszych słowach pracy Unediting the Renaissance stawia ciąg pytań, które warto przytoczyć, jako że bazuje ona na tekście z bardzo odległej epoki. Badaczka zastanawia się zatem:

\footnotetext{
Czego mamy nadzieję doświadczyć, kiedy czytamy tekst literacki z wcześniejszej epoki? Czy poszukujemy niezakłóconego dostępu do kultury bardzo odległej od naszej, czy kontaktu z umysłem pisarza z minionych czasów? Czy szukamy rozrywki, wskazówki, moralnej oceny czy ucieczki? Czy spotkania z transcendencją, instynktownego zaangażowania w konflikty z przeszłości, czy dojrzenia czegoś obcego? Czy tylko niektórych, czy wszystkich z powyższych możliwości, choć mogą wyglądać na wzajemnie się wykluczające (1996: 1).
}

Do tak znaczących pytań dodaje Marcus jeszcze jedną podstawową wątpliwość, szczególnie istotną w przypadku dużej liczby dzieł przypisywanych jednemu autorowi. Chodzi tu o różne wersje sztuk, znanych pod nazwą „złych” i „dobrych” quarto oraz o pierwsze folio. Uznanie jednej wersji za gorszą od innej ustanowiło literacki kanon dramatów Szekspirowskich, spośród których jedne bardziej zasługują na krytykę literacką, inne zaś mniej. Według Marcus, błędnym podejściem jest ustanowienie hierarchii dzieł, która deprecjonuje konkretne („złe”) wersje sztuk, będące w obiegu od czasów renesansowych. Takie podejście bowiem w dużej mierze decyduje o sięganiu do tak zwanych „dobrych” wersji sztuki przez badaczy literatury oraz przez współczesnego czytelnika. Autorka Unediting the Renaissance zachęca do wzięcia pod uwagę „tekstualnej niestabilności” i zdania sobie sprawy, że wczesne manuskrypty i drukowane wydania dzieł danego autora składają się raczej z wielu wersji, nie zaś z jednego autorskiego tekstu-monolitu (1996: 
27). Badaczka ujmuje to następująco: „Nie mamy jednego Hamleta. Możemy cieszyć się trzema powiązanymi wersjami Hamleta, z których każdy zajmuje inne miejsce w przestrzeni pomiędzy werbalnością a piśmiennością" (176).

Pamiętając o braku oryginału Hamleta oraz o istnieniu wielu wersji tego utworu, wybrałam jedno z wielu jego wydań - z serii The Arden Shakespeare. Jest to wersja bazująca na drugim quarto. Decyzja o posłużeniu się wersją „W dobrym guście” (przytaczając słowa Marcus) nie jest podyktowana niechęcią do innych kopii dramatu. Sensorycznie i metaforycznie wyjaśniając tę kwestię - możliwe, że to zmysł smaku intuicyjnie podpowiedział wybór tej wersji. Warto w tym miejscu zwrócić uwagę na słownictwo z zakresu zmysłów, którym posługuje się Marcus dla określenia jakości odmiennych wersji Hamleta. Autorka wspomina o wypracowaniu „wspólnych standardów gustu" (1996: 136) w zakresie obcowania z konkretnymi wersjami tragedii i twierdzi, że w kulturze zachodniej występuje ciągła potrzeba, by dystansować się od najstarszej wersji Hamleta, czyli pierwszego quarto (36). Według badaczki wersja z 1603 roku być może zakłóca nierozpoznawalne na pierwszy rzut oka, zbiorowe założenia dotyczące Szekspira i jego miejsca w tej kulturze (36).

Marcus stawia tezę, że funkcjonowanie szekspirowskiego teatru było znacznie bardziej oparte na tradycji mówionej aniżeli piśmiennej, stąd wcześniejsze wersje Hamleta mogą mieć więcej wspólnego z dość istotnymi naleciałościami kultury niepiśmienno-słuchowej niż z rodzącą się kulturą wizualną (1996: 36-37). Tradycyjne wydania sztuk(i) preferują pierwsze folio (1623) jako najwłaściwszą wersję tragedii - gdyż najbardziej zbliżoną do „kulturowo zdeterminowanych standardów literackiej wspaniałości” (135) - odgórnie kształtując gusta badaczy i czytelników. Wydania przyczyniają się tym samym do ewaluacji tekstu w kategoriach „bardziej bądź mniej cywilizowanego”. Nie mając pewności, która kopia Hamleta jest „najbardziej Szekspirowska" w sensie literackiej doskonałości, samej w sobie obarczonej subiektywizmem, warto założyć za Marcus, że „Hamlet, tak jak go zwykle odczytujemy, jest skomplikowaną mozaiką odczytań zaczerpniętych z wczesnych quarto i folio oraz mających długą tradycję korekt wydawniczych, dzięki którym elementy nieregularności i groteskowości początkowych tekstów zostały wygładzone" (1996: 134). Dobry bądź zły gust, którym kierujemy się przy wyborze jakiegokolwiek materiału kulturowego, stanowi wypadkową wielu czynników zdeterminowanych kulturowo (na przykład płeć, rasa, wiek, status społeczny) oraz jest percepcyjnie zależny od czasu i miejsca zetknięcia się z tym materiałem. Badaczka twierdzi, że w przypadku Hamleta „zły smak wiąże się z przestarzałą teatralną kulturą słowa” (1996: 137), z kolei „dobry smak jest łączony z pisaniem jako przeciwieństwem mówienia; a »dobry« Szekspir - z tworzeniem teatru, który w szczególności jest oparty na piśmiennictwie" (137). 
Na poziomie tekstu różnica pomiędzy „złym” a „dobrym” Hamletem leży przede wszystkim w precyzyjności języka i estetycznych preferencjach kultury wizualnej albo akustycznej (Marcus, 1996: 156). Jeśli „złe” quarto uznać za przykład zapisu zakorzenionego w kulturze słownej, to ów tekst charakteryzuje się między innymi tym, że osobowość postaci na scenie może być dynamicznie odgrywana podczas przedstawienia, ale postać może się wydawać bezbarwna na papierze. Brakujący element stanowi w tym przypadku precyzja i realizm, tak ceniony u Szekspira przez zachodnią kulturę pisma. „Złe” quarto lepiej sprawdza się na scenie także pod względem „wybrakowanej wersyfikacji”, praktycznie niezauważalnej podczas gry aktorskiej (156). „Dobre" quarto jest bardziej dopracowane pod względem językowej regularności (regularne metrum) oraz czystości leksykalnej (np. mniej kolokwializmów) i charakteryzuje się bardziej żywym, precyzyjnym i rozbudowanym językiem, większą przejrzystością i złożonością syntaktyczną (156). Ta ostatnia wersja Hamleta byłaby wersją w szczególności przewidzianą dla czytelnika (a nie dla widza), pozbawioną „niejasności, zawiłej składni i dziwnej bezpośredniości przekazu”, przypisywanej wersji „w złym guście” (157).

Odmienne wersje sztuki odzwierciedlają renesansową batalię pomiędzy późnoakustycznym a wczesnowizualnym wymiarem kultury tego okresu. Pokazują też, w jaki sposób zróżnicowane formy zapisu i przekazu jednej sztuki decydują o odbiorze tekstu jako bardziej piśmiennego lub bardziej mówionego. Dodatkowo, istotna z punktu widzenia kultury wczesnonowożytnej wydaje się teza autorki Unediting the Renaissance:

Każda kultura teatralna była środowiskiem, w którym formy mówione i pisane konkurowały ze sobą i rywalizowały o lojalność odbiorców. Była środowiskiem, w którym oczekiwania przekazu piśmiennego stopniowo stawały się coraz bardziej popularne, oddalając się od wcześniejszych, słownych form przekazu (1996: 155).

Zapis i odbiór sztuki powstałej w okresie kultury wczesnej nowożytności niewątpliwie różni się od współczesnych sposobów odbioru oraz form prze-pisania dramatu, rozumianego jako zmodyfikowanie Hamleta dla potrzeb kultury postmodernistycznej. W kontekście kultury współczesnej sztuka ta nabiera nowego znaczenia, nie tylko ze względu na zmienne kulturowe preferencje zmysłowe, i przy tym odmienne reakcje sensualne odbiorców, ale także z powodu innego niż tekstowy zapisu dramatu - zapisu filmowego. Przeniesione na ekran adaptacje Hamleta stanowią uzewnętrznienie kultury wizualnej w postaci przekazów filmowych. W ich przypadku sztuka jest zazwyczaj odtwarzana/ożywiana w formie zmodyfikowanego „oryginału bez oryginału".

Korzystając z dramatu, który wywodzi się z wczesnonowożytnej kultury percepcyjnej, współczesne filmowe wersje Hamleta istnieją dzięki „wchło- 
nięciu" różnorodnych sensów, tworząc nowe znaczenia. Warto w tym miejscu przywołać termin „energia społeczna” autorstwa Stephena Greenblatta. Oznacza on, że teksty kulturowe posiadają potencjał energetyczny, utrzymujący ich żywotność w kolejnych epokach, zarówno po śmierci autora, jak i przeminięciu kultury, w jakiej powstały. W przypadku Hamleta zakodowana w utworze „energia społeczna” czasów szekspirowskich byłaby na przykład

siłą retoryczną semiotycznych reprezentacji, które były zbiorowo tworzone w specyficznych, historycznych warunkach elżbietańskiej Anglii, dzięki istnieniu „subtelnej i nieuchwytnej wymianie, sieci transakcji handlowych i barterowych, ... stałego udzielania pożyczek i dokonywania zapożyczeń" między różnymi dyskursami i praktykami społecznym. Sztuki i teatr Szekspira zaadaptowały te formy dyskursywne, socjolekty, toposy, gatunki mowy oraz semantykę społeczną, by je zmodyfikować i w ten sposób zwiększyć swoją energię społeczną. To dlatego tak wiele radykalnie odmiennych, następujących po sobie kultur mogło odnaleźć w światach wymyślonych przez Szekspira „ślady” rozbudowanych formacji minionego życia. Dzięki wpisanej w nie [sztuki Szekspira] „energii społecznej” ślady minionego życia - które były sztuczne i przekazywane nam w spadku poprzez „na wpół ukryte transakcje kulturowe” - są zdolne do tego, by wciąż na nowo „wytwarzać, kształtować i porządkować psychiczne i umysłowe doświadczenia ogółu”, nie pomijając estetycznej przyjemności (Juvan, 2008: 111).

Jest więc Hamlet z okresu wczesnonowożytnego „artystyczną reprezentacją odnoszącą się poprzez kulturową symbolikę do heterogenicznego, społeczno-kulturowego otoczenia, które go wytworzyło" (Juvan, 2008: 112). Krążąca „energia”, zapisana w dziełach Szekspira daje możliwość kolejnych odtworzeń jego dzieł w różnorodnych formach, w tym w wersji filmowej. Skoro adaptacja filmowa to dzieło - sięgające do innego utworu, które samo nie posiada jednego źródła, lecz jego niejednorodna genetycznie struktura składa się z kolekcji zapożyczeń reprezentacji na strukturę o niejednorodnym rodowodzie - słuszne wydaje się przywołanie koncepcji intertekstualności. Teoria ta odnosi się do zależności istnienia jednego materiału kulturowego od już istniejących. Julia Kristeva określiła zjawisko rodzenia się sensów z istniejących już sensów, a więc produkcję sensów zamiast jej wymiany, mianem semanalizy. Krzyżowanie się różnych znaczeń na poziomie tekstualnym zainspirowane było koncepcją Michaiła Bachtina o dialogicznym charakterze utworu literackiego. $\mathrm{W}$ trakcie dialogu następuje nie tylko wymiana znaczeń z „chwili obecnej”, zrozumiałych kontekstowo, lecz także „cytowanie” istniejących już słów, a więc zapożyczeń od poprzednich pokoleń. Kwestionując założenia semiologii strukturalistycznej, stojącej na stanowisku wymiany sensów, Kristeva zreformowała i zreformułowała to podejście, uznając intertekstualność za cechę właściwą tekstom, a dialogiczność za inspirującą czytelnika możliwość obcowania z sensami (Cavallaro, 2003: 79-80).

W opinii Bartona Palmera: „Intertekstualność kwestionuje przyjęty pogląd, dotyczący zamkniętych i samowystarczalnych »dzieł«, nieprzepusz- 
czalności ich granic wobec zewnętrznych oddziaływań i niechęci żywionej w stosunku do obcych form" (2007: 3). Ponadto, zdaniem tego autora, intertekstualność stanowi zaplecze teoretyczne dla „wspólnej tożsamości źródła literackiego i jego filmowego odbicia" (3). W rezultacie postmodernistyczne adaptacje sztuki w intertekstualny sposób przywłaszczają teksty kulturowe, w tym dramat Hamlet, i jednocześnie przyczyniają się do podniesienia poziomu „energii społecznej” swoich czasów.

W przypadku analizy związku pomiędzy adaptacją dzieła literackiego dla potrzeb kinematograficznych a nim samym, najbardziej widoczną zależnością jest przyczynowe powiązanie obu wytworów kulturowych. Uznanie tekstu Hamleta za podstawowe źródło inspiracji przy tworzeniu jego adaptacji nie wyklucza zaakceptowania stwierdzenia, że poszczególne filmowe wersje dramatu cytują się nawzajem i zapożyczając od siebie różne reprezentacje zmysłów, przekształcają je w inne, nowsze. Zestawienie wyobrażeń zmysłów, przeniesionych na ekran filmowy, z ich literackimi reprezentacjami ma na celu pokazanie nie tylko odmienności w obrazowaniu postrzegania zmysłowego za pomocą dwóch środków przekazu, ale także procesu zapożyczeń i modyfikacji reprezentacji zmysłów, w efekcie składającego się na Hamleta palimpsestowego. 



\section{Ślady życia sensualnego z dawnej epoki}

\section{Na pozór nieuchwytne - zmysły w literaturze}

Jeśli za Bullem i pozostałymi badaczami zmysłów przyjąć, że „zmysły są wszędzie", wówczas zadaniem badaczy literatury staje się analiza reprezentacji zmysłów w utworach literackich. Omawiane dzieło Szekspira jest jednym z wielu materiałów kulturowych, wzbogacających wiedzę na temat historii zmysłów, która, ponieważ została spisana językiem dramatu, wymaga odmiennego odczytania niż na przykład powieść. Stwierdzenie Elizabeth D. Harvey, zaczerpnięte z pracy Ventriloquized Voices: Feminist Theory and English Renaissance Texts (1992), dobrze oddaje proces interpretacji i odtwarzania tekstu literackiego: „Historyczne rekonstrukcje zawsze są rodzajem brzuchomówstwa, dlatego istotną kwestią jest spowodowanie, by przeszłość wydawała się mówić głosem, jakiego udziela mu teraźniejszość" (1992: 6). Kulturowy głos z przeszłości w końcu rozbrzmiewa, lecz zawsze jest już tylko głosem, przechodzącym przez istniejącego w teraźniejszości „brzuchomówcę", na przykład badacza dzieł Szekspira.

W przypadku dzieła dramatycznego sposobem na dotarcie do odległego w czasie i odmiennie praktykowanego życia sensualnego jest zwrócenie uwagi na coś, co określam mianem osobliwego kodu sensorycznego utworu. Wówczas celem analizy literackiej staje się „wyciągnięcie na światło dzienne” wartości sensorycznych, zakodowanych w tekście sztuki. Owe wartości, które oddają ścierające się kulturowe paradygmaty i ideologie, są produkowane i podtrzymywane przez różne grupy społeczne. Howes podsumowuje system złożony z wartości sensorycznych, tłumacząc, że

nigdy nie jest on w pełni wypowiedziany w języku, ale praktykowany i doświadczany (a czasem podważany) przez ludzi, będących nośnikami kultury. Porządek sensoryczny w rzeczywistości nie jest tylko czymś, co się widzi, czy o czym się słyszy; jest to coś, co się przeżywa ([podkreślenie autora] 2005: 3).

Utwór literacki składa się jednak wyłącznie ze słowa pisanego, a to z kolei stanowi jedyny ślad, który prowadzi do zaszyfrowanego zapisu porząd- 
ku sensualnego danej kultury. Teksty kulturowe składają się i dostarczają reprezentacji sensualnego wymiaru kultury. Odzwierciedlają zatem model sensoryczny i wartości, wytworzone i odtwarzane w ramach przeżywanego doświadczenia przez ludzi żyjących w określonych czasoprzestrzennych warunkach społecznych. Skoro dzieło literackie nie pozwala na bezpośredni kontakt z praktykami sensorycznymi i doświadczeniami zmysłowymi z przeszłości, to celem takiego tekstu jest pośredniczenie pomiędzy współczesną odmianą sensorycznej egzystencji a minioną percepcyjną obecnością. Poprzez analizy materiałów kulturowych studia nad zmysłami przybierają formę sensorycznie uwarunkowanego wyzwania. Hamlet, jako najczęściej analizowany dramat Szekspirowski, podlegał już krytycznym przemyśleniom, będąc w zasięgu takich szkół krytycznych jak na przykład psychoanaliza czy feminizm ${ }^{1}$. Jednak wydaje się, że nigdy nie podlegał ujęciu sensorycznemu i nie został całościowo zbadany pod kątem reprezentacji świata zmysłów.

Wejrzenie $\mathrm{w}$ literacki świat cudzego doświadczenia odsłania istotny aspekt ludzkiego funkcjonowania w kulturze, a mianowicie pozwala na wstępną ocenę stanu wiedzy na temat mechanizmów i procesów percepcyjnych w czasach renesansu. 0 różnych sposobach poznania kultury z przeszłości pisze Lorna Hudson w The „Double Voice” of Renaissance Equity and the Literary Voices of Women (2000). Podkreśla, że Szekspir jest przedstawicielem swojej epoki, więc obecne w jego dramatach reprezentacje życia sensorycznego czasu, w jakim funkcjonował, należy traktować jako jedną z możliwych w tej epoce wersji oglądu świata (2000: 142). Jednocześnie stanowią one bezcenne źródło wiedzy o kulturze wczesnej nowożytności. Należy jednak ciągle pamiętać, że dramaturg kreował postaci z punktu widzenia mężczyzny, żyjącego w zmaskulinizowanej kulturze percepcyjnej.

Szekspir porusza w dramatach tematykę dosłownego oraz przenośnego rozumienia słyszenia i widzenia. Tekst Hamleta pozwala prześledzić natężenie użycia określeń związanych ze zmysłami odpowiedzialnymi za widzenie i słyszenie. Odwołując się do statystyki przeprowadzonej na potrzeby poznania częstotliwości występowania percepcyjnych określeń w sztukach Szekspira, Mark L. Caldwell w artykule "Hamlet and the Senses” podaje, że słowa „oko, ucho, obserwować, słuchać, widzieć, patrzeć, nos, czuć zapach

\footnotetext{
${ }^{1} \mathrm{~W}$ ramach krytyki psychoanalitycznaej pojawiły się m.in. następujące prace: The Interpretation of Dreams (1899) Zygmunta Freuda, Psychoanalysis and Shakespeare (1966) Normana N. Hollanda czy After Oedipus: Shakespeare in Psychoanalysis (1993) Kennetha Reinharda i Julii Reinhard Lupton. Krytyka feministyczna obejmuje m.in. takie kluczowe prace, jak: Shakespeare and the Nature of Women (1975) autorstwa Juliet Dusinberre, The Woman's Part: Feminist Crticism of Shakespeare (1981), zredagowana przez Carolyn Ruth Swift Lenz, Gayle Greene i Carol Thomas Neely, czy też jeden z nowszych zbiorów esejów A Feminist Companion to Shakespeare (2000) pod redakcją Dympny Callaghan.
} 
oraz ich warianty występują 270 razy" (1979: 140)². W porównaniu z Królem Learem i Otellem, dramatami o podobnej objętości, wspomniane słowa pojawiają się odpowiednio 188 i 202 razy. W opinii Caldwella w Hamlecie słownictwo z tego zakresu zwykle pojawia się „w postaci zagęszczonych skupisk, przyciągających uwagę dzięki ich bliskiemu położeniu" (1973: 140). Na przykład w Hamlecie (na 3906 wersów sztuki) słowo „oko” pojawia się 38 razy, zaś „ucho" - 25. Z kolei słowa „widzieć” (see) i „słyszeć” (hear) występują odpowiednio 79 i 58 razy. Według mojego zestawienia, przeprowadzonego na potrzeby niniejszej pracy, wyrażenia zawierające słowa „ucho/uszy” (ear/s) pojawiają się w tekście dramatu 25 razy, zaś frazy ze słowami „oko/ oczy" (eye/s) występują 38 razy $^{3}$. Jeśli dołączyć do tego natężenie, z jakim naprzemiennie pojawiają się czasowniki „widzieć” (see) i „słyszeć” (hear), odpowiednio 83 i 55 razy, to może okazać się, że Hamlet od ponad czterystu lat fascynuje niepoznawalnością świata zmysłów w nim przedstawionych, mamiąc zmysły krytyków i widzów. Być może też, parafrazując pytanie Oscara Wilde'a, czy krytycy są w obłędzie i wcale nie udają swego szaleństwa na punkcie Hamleta, należałoby dać pozytywną odpowiedź, że doznają „pomieszania zmysłów” w trakcie lektury sztuki. „Wydarcie tajemnicy” dziełu polegałoby zatem na rozszyfrowaniu jego sensorycznego kodu.

Greenblatt w Shakespearean Negotiations: The Circulation of Social Energy in Renaissance England (1988) zaproponował koncepcję „rozmowy z umarłymi”, mając na myśli dotarcie do ducha epoki i „ożywienie” go poprzez analizy tekstów z przeszłości. „Dialog z umarłymi” jest na pierwszy rzut oka paradoksalnym przedsięwzięciem, możliwym jednak do wykonania, jeśli założyć, że za pomocą tekstualnych śladów można ożywić przeszłość z perspektywy teraźniejszości. Gdyby rozbudować pytanie postawione przez Greenblatta: „[w] jaki sposób aż tyle życia dostało się do śladów tekstualnych?” (1988: 2), pytając: „W jaki sposób aż tyle życia sensualnego dostało się do śladów tekstualnych?", wówczas w szczególności ślady przeszłości w postaci tekstu Szekspirowskiego mogłyby choć częściowo „wskrzesić” życie sensualne ludzi renesansu.

\section{Zmysły daja się „nakręcić”}

Ufilmowienie, a więc uchwycenie okiem kamery takiego zjawiska, jakim jest ludzkie postrzeganie zmysłami, wymaga potraktowania go w kategoriach konstruktu kulturowego, który można przedstawić za pomocą repre-

\footnotetext{
${ }^{2}$ Przedstawione przez badacza dane, porównujące sztuki pod względem wyrażeń percepcyjnych, pochodzą z The Harvard Concordance to Shakespeare (1973).

${ }^{3}$ Posługuję się wydaniem Hamleta z serii The Arden Shakespeare, red. Ann Thompson, Neil Taylor, 2006.
} 
zentacji na ekranie filmowym. Sensy komunikowane obrazowaniem filmowym, podobnie jak w przypadku tekstu, jednak za pomocą innych konwencji, wyłaniają się z dzieła filmowego. Analiza elementów poetyki szczególnego dzieła filmowego, jakim jest adaptacja, odsłoni sposoby ujmowania zmysłów zastosowane przez trzech różnych reżyserów filmowych. Wybrane adaptacje powstały w ostatnim dziesięcioleciu XX wieku, tworząc ciąg Hamletów postmodernistycznych z lat: 1990, 1996 i 2000. Są to najczęściej analizowane adaptacje sztuki, pomimo istniejących kilkudziesięciu filmowych wersji dramatu. Hamlet bowiem to jednocześnie najczęściej przekładane na język filmowy dzieło Szekspira (Cartmell, 2000: 24). Pierwszy ufilmowiony fragment tej tragedii zainicjował niezwykłe związki Szekspira z filmem w XX wieku.

Za pierwszy film z wykorzystaniem analizowanej sztuki uznaje się zapisaną na taśmie filmowej scenę z Króla Jana z 1899 roku, odegraną przez Herberta Beerbohma Tree (Collick, 1989: 34). Według Johna Collicka, autora Shakespeare, Cinema, and Society (1989), Tree, który był wówczas jednym z czołowych aktorów-menedżerów, skorzystał w swojej produkcji z osiągnięć wiktoriańskiej sceny teatralnej: „Była to żywa i wywołująca wrażenie mieszanka precyzyjnie uzyskanego historycznego szczegółu, widowiskowości i niemej, »odmalowanej « kompozycji” (35). Jako pierwszy film szekspirowski, Król Jan zapoczątkował styl filmowy, który wyrósł z tradycji teatralnej. Jak podaje J. Lawrence Guntner „[e]ra Szekspira w filmie rozpoczęła się podczas Paryskiej Wystawy w 1900 roku projekcją pięciominutowego filmu Hamlet, wyreżyserowanego przez Maurice'a Clémenta. Główną rolę grała Sarah Bernhardt jako Hamlet i Pierre Magnier jako Laertes" (2007: 120). Pierwsza adaptacja fragmentu Hamleta równocześnie stanowi jedną z początkowych prób przeniesienia bogactwa języka Szekspirowskiego dramatu na dopiero rozwijający się język filmowy.

Adaptacje, będące przedmiotem analizy niniejszej pracy, są jednymi z ostatnich filmowych wersji Hamleta, a więc takich, które ukazują ewolucję języka filmowego i nowoczesnej techniki filmowej, a także epokowe następstwa rozwoju zachodniego wzrokocentryzmu. Zeffirelli, Branagh i Almereyda osadzili akcję sztuki w odmiennych epokach: od średniowiecznych realiów, poprzez epokę wiktoriańską, po współczesny Nowy Jork. Każda z adaptacji stanowi materiał kulturowy, który umożliwia odnalezienie w nim przedstawień percepcji zmysłowej. Adaptacja pozwala, aby sensoryczny świat zaistniał w postaci obrazu i dźwięku. Inaczej niż sam tekst dramatu, adaptacja unaocznia i „istnieje” bardziej realnie niż tylko jako wytwór wyobraźni czytelnika.

Analizowane w pracy adaptacje Hamleta obejmują - jak już wspomniano - ostatnią dekadę XX wieku. W ramach studiów sensorycznych przyjmuje się, że jest to okres nie tylko zdominowany przez badania nad kulturowym znaczeniem wzroku, ale także przez kulturowe praktyki wzrokowe, wyznaczają- 
ce temu zmysłowi dominującą pozycję w kulturze Zachodu. Najbardziej dystansujący organ percepcji w dużej mierze zorganizował współczesny kształt życia estetycznego, objawiającego swe istnienie w postaci artefaktów kulturowych. Etymologicznie słowo „estetyka” pochodzi od greckiego aisthētikós, co znaczy „postrzegany zmysłami”" Jednak w odniesieniu do współczesnej kultury naoczności, estetyczna żywotność wytworów kulturowych zależy przede wszystkim od ich wizualnej atrakcyjności, od postrzegania zmysłem wzroku.

Wybrane adaptacje filmowe wpisują się we wzrokocentryczne realia postmodernizmu. Poprzez wybór wizualnych motywów przewodnich w swoich interpretacjach dramatu Szekspira reżyserzy, których dzieła są przedmiotem mojej analizy, uwypuklają znaczenie zmysłu wzroku. U Zeffirellego są to nieustannie spoglądające na siebie oczy bohaterów, u Branagha - wszelkie odbijające lustrzane powierzchnie, u Almereydy zaś - technologiczne „oczy obiektywów". Z jednej strony na plan pierwszy wysuwają się więc filmowe reprezentacje percepcji wizualnej, z drugiej zaś - percepcja audialna poszczególnych bohaterów, zainfekowana przez rzeczywistą truciznę oraz metaforycznie rozumianą toksyczność słów, pozostaje jednym z przewodnich wątków strukturalnych w każdej z adaptacji.

\section{Bohaterowie „Hamleta” jako (mniej bądź bardziej uważni) obserwatorzy i słuchacze}

Kluczowym problemem w Hamlecie jest kwestia ludzkiego poznania za pomocą postrzegania zmysłowego, czyli sensorycznej aparatury ciała (głównie oczy i uszy). Z tekstu sztuki wyłania się obraz ludzi „przeżywających” rzeczywistość fikcyjną w sposób sensualny. Percypować w tym przypadku to zaznaczać swoją literacką egzystencję, przechodząc z jednego stanu postrzegania zmysłami w inny. Poszczególne postacie dramatu doznają różnych wrażeń zmysłowych, spośród których wyróżniają się doświadczenia wzrokowe i słuchowe. Dramat otwiera pytanie: „Kto idzie?”, postawione przez oficera Bernarda, zmierzającego na zmianę nocnej warty w zamku Elsynor. Zapewne ciemność, jaka otacza Bernarda, jest jednym z powodów zagubienia, które próbuje przezwyciężyć, nasłuchując odpowiedzi czy też wypatrując nadchodzącej postaci. Ze wzrokiem utkwionym w otoczeniu w poszukiwaniu odpowiedzi, ze słuchem wytężanym wielokrotnie do granic możliwości, począwszy od pierwszej sceny, postaci Szekspirowskie za pomocą zmysłów doznają zmian zachodzących w ich otoczeniu. Literackie reprezentacje wrażeń zmysłowych dają sposobność do wglądu w świat odmienny od osobistego,

\footnotetext{
${ }^{4}$ Definicja pochodzi ze strony http://www.slownik-online.pl.
} 
a więc subiektywnego doświadczania zmysłowego. Można spróbować zgłębić konstrukcję zmysłów i przypisanych im doświadczeń, dzięki analizie elementów wizualnych i werbalnych w omawianym dramacie Szekspira. Literackie obrazowanie doznań zmysłowych postaci dramatu należy odczytać jako jedno ze źródeł wiedzy o kulturze percepcyjnej w danym okresie historycznym.

Postaci dramatu często nie dowierzają temu, co słyszą, potrzebując wzrokowego dowodu, który można by nazwać „materializującym efektem wzrokowości". Zachodzi też odwrotne zjawisko, a więc zwątpienie i niewiara w to, co jawi się oczom bohaterów. Dlatego wielokrotnie dopiero czyjaś opowieść i wymiana opinii weryfikuje wrażenia wizualne. Problem wiedzy i poznania usytuowany jest w świecie zmysłów, łącząc koncepcje na temat ludzkiej percepcji z rozważaniami dotyczącymi ograniczeń ciała związanych z postrzeganiem oraz przekraczaniem granic, które stawia powłoka somatyczna. Wyłaniający się $\mathrm{w}$ renesansie paradygmat antropocentryczny znajduje odzwierciedlenie w koncepcjach zmysłów, ujmowanych jako przedmiot dociekań i refleksji humanistycznej. Wydaje się, że Szekspira-humanistę mogły nurtować poznawcze aspekty widzenia i słyszenia. Stąd też uczynił głównego bohatera dramatu poszukiwaczem prawdy, interpretatorem zachowań pozostałych mieszkańców Elsynoru, a także - w przypadku ducha - przybyszy z zaświatów.

Dla Hamleta, czyli głównego obserwatora i kreatora wypowiedzi, jak i dla pozostałych postaci dramatu, niedoskonałymi narzędziami interpretacyjnymi są ich zmysły. Poprzez odpowiednią konstrukcję postaci Szekspir wyposażył je w indywidualną zdolność słuchania, wypowiadania się, obserwacji i odczuwania, co z kolei pozwala na wzajemne sensualne poznawanie pozostałych bohaterów, w tym ich zachowań percepcyjnych w zakresie słuchania i widzenia. Rembowska-Płuciennik zwraca uwagę na „wzajemny sensualny odbiór" poszczególnych postaci (2004: 338)5. Podkreśla też wyłaniające się z tekstu „stany obserwowanej osoby”, umożliwiające „bezpośredni wgląd w drugiego" (339). Po analizie tekstu Hamleta nieuniknione wydaje się stwierdzenie, że w sztuce występuje rozmaite słownictwo z zakresu doświadczeń oraz wrażeń sensualnych, docierających do poszczególnych postaci - w przeważającej części - dzięki zmysłowi wzroku i słuchu.

Według Caldwella każda scena, z wyjątkiem monologów Hamleta, obfituje w „obserwowanie, słuchanie lub szpiegowanie kogoś innego”, co wywołuje efekt dramatyczny (1979: 137-138). W streszczeniu sztuki, akcentując wątki obserwacyjno-szpiegowskie oraz (pod)słuchowe, krytyk tak pisze o Hamlecie:

\footnotetext{
${ }^{5}$ Autorka nie zajmuje się sztukami Szekspira, lecz analizuje utwory składające się na trylogię ukraińską Włodzimierza Odojewskiego. Jednak jej spostrzeżenia na temat relacji między bohaterami prozy są również niezwykle użyteczne dla badań tekstów dramatycznych.
} 
Rozpoczyna się czyhaniem na ducha przez Bernarda i Franciszka. Potem następuje przeniesienie do Gertudy i Klaudiusza, obserwowanych w trakcie narady przez ostentacyjnie milczącego Hamleta. Przywołany przez Horacja i Marcela, dołącza do wartowników. Po ponownym pojawieniu się ducha Horacy i Marcellus śledzą i uważnie obserwują przebieg tego spotkania. Poloniusz uknuwa spisek, by szpiegować Hamleta i Ofelię, zaś Klaudiusz wykorzystuje Rosencrantza i Guildensterna do szpiegowania Hamleta: „do każdego ucha jeden słuchacz" ${ }^{6}$. Hamlet obmyśla spisek - chce wystawić sztukę, którą ma obejrzeć Klaudiusz i Gertruda, będący pod baczną obserwacją Horacja. Po uruchomieniu pułapki na myszy Hamlet przygląda się modlącemu Klaudiuszowi, a sam jest podsłuchiwany przez Poloniusza w scenie spotkania z matką w jej komnacie. W towarzystwie Rosencrantza i Guildensterna Hamlet śledzi armię Fortinbrasa [...]. Zaraz po tym Horacjo, Gertruda i Klaudiusz biernie obserwują szaloną Ofelię. Hamlet powraca z wyprawy, by przyjrzeć się procesji pogrzebowej Ofelii; Klaudiusz i Gertruda widzą walkę Hamleta z Laertesem nad grobem; i ostatecznie, w ironicznej parodii tejże sceny oraz sztuki-w-sztuce, Klaudiusz planuje obejrzeć przedstawienie - udawany pojedynek pomiędzy Hamletem i Laertesem, którego następstwem jest krwawa i niespodziewana scena finałowa (1979: 138).

Szekspir posłużył się dramatyczną strategią, której elementem jest zależność przebiegu wydarzeń scenicznych od sposobu, w jaki bohaterowie wykorzystują swoje zmysły w danym momencie akcji. Nie tylko bowiem używają swych oczu i uszu do oceny zachowań innych, ale także po to, by stać się zauważonymi i usłyszanymi w konkretnym celu.

Wyobrażenia o zmysłach w Hamlecie (w tym również wyobrażenia o kobiecych doświadczeniach sensualnych), mimo że zaprezentowane z męskiego punktu widzenia, oddają ówczesną perspektywę percepcyjną kobiet. Kobiecą słuchowość i wzrokowość synekdochicznie reprezentują w dramacie tylko „dwie pary uszu i oczu” - część aparatury poznawczej. Poszczególne rozdziały będą prezentować interpretację opartą na założeniu, że stanowiąc „sensoryczną mniejszość”, kobiety w odmienny sposób okazują swoją sensualną obecność/obcość poprzez właściwe im zachowania angażujące zmysły. Nieustannie podglądane i podsłuchiwane bohaterki Hamleta są często ukazane tak, by ich doświadczenia zmysłowe były pasywne. Wiadome jednak jest, że zarówno Ofelia, jak i Gertruda (rozumiane jako postacie fikcyjne) również aktywnie postrzegają rzeczywistość świata przedstawionego. Literacka kreacja zachowań Gertrudy i Ofelii może zostać potraktowana jako zobrazowanie zaangażowania zmysłów w aktywny proces widzenia i słyszenia. Takie podejście implikuje to, że kobiece postacie wkraczają na drogę transgresji, ilekroć przełamują stereotypowe (bierne) zachowania percepcyjne. Innymi słowy, ich status społeczny przybiera formę liminalności - zawieszenia w przestrzeni elsynorskiej.

\footnotetext{
${ }^{6}$ Chodzi tu o zwrot pochodzący z tekstu sztuki: „at each ear a hearer” (2.2.388-89), który Caldwell przytacza w artykule.
} 
Victor W. Turner, który na polu antropologii kulturowej spopularyzował zjawisko liminalności, podaje, że:

Byty liminalne nie przebywają ani tu, ani tam; znajdują się pomiędzy pozycjami wyznaczonymi i uporządkowanymi przez prawo, zwyczaj, konwencję i ceremoniał. Ich niejednoznaczne i nieokreślone atrybuty znajdują wyraz w bogatej różnorodności symboli w wielu społeczeństwach, które zmianę kulturową i społeczną sankcjonują obrzędami. Liminalność jest często przyrównywana do śmierci, do pobytu w łonie matki, do bycia niewidzialnym, do ciemności, do biseksualności, do odludzia i do zaćmienia słońca czy księżyca (2004: 241).

Kobiece bytowanie „pomiędzy” to - w przypadku społeczeństwa zbudowanego na "męskiej dominacji” (także hierarchicznej dominacji społecznej, opartej na wartościowaniu zależnym od kulturowego zaszeregowania zmysłów) - strategia pozwalająca na odnalezienie miejsc oporu wobec androcentrycznych zakazów odnoszących się do kobiecych zachowań i doświadczeń w zakresie zmysłów.

Pierre Bourdieu zwraca uwagę na możliwość zastosowania przez kobiety „miękkich” symbolicznych strategii oporu, jak na przykład oporu słownego w postaci wypowiadania zaklęć lub kłamstw, które „są narzędziami grupy zdominowanej". Jest to forma kobiecej, głosowej reakcji, wynikającej z doświadczeń słuchowych, powodowanych „wsłuchiwaniem się” w zmaskulinizowany głos kultury patriarchalnej. Skuteczność „miękkich” symbolicznych strategii oporu ocenia się zazwyczaj jako niezwykle słabą, gdyż zamiast wywoływać zmianę, przynoszą one potwierdzenie wyobrażeń o kobietach jako negatywnych postaciach: przebiegłych, złych i demonicznych (Bourdieu, 2004: 44). Jednak, w opinii francuskiego socjologa, takie reprezentacje kobiecości wyrastają z męskiego punktu widzenia, sformułowanego według znaturalizowanego porządku rzeczy. Ten zaś oparty jest na binarnym podziale na męskie/silne/jasne wobec kobiecego/słabego/ mrocznego, odcinając drogę odmiennemu spojrzeniu na kobiece praktyki sensualne. Wyjaśniając siłę męskiego porządku, Bourdieu opisuje jego mechanizm działania w następujący sposób: „Wyjątkowa siła męskiej socjodycei pochodzi bowiem ze zdolności do połączenia dwóch relacji dominacji przez wpisanie jej w naturę biologiczną, która sama w sobie jest już znaturalizowaną konstrukcją społeczną" (33).

Objęcie tym schematem zmysłów w sensie „rzeczywistości biologicznej” powoduje, że wpisane w nie zostaje społeczne podejście do ludzkiego sensorium. Stany liminalne będą stanowić wyzwanie dla reprodukowanych przez porządek patriarchalny zasad społecznego postrzegania kobiecego doświadczenia opartego na postrzeganiu zmysłami. Zwrócenie uwagi na reprezentacje transgresyjnych zachowań sensorycznych ma na celu ukazanie niejednorodnej kultury percepcyjnej okresu, w jakim żył Szekspir, z wyodrębnieniem kultury dominującej i marginalizowanej. 


\section{„Hamlet" i dwa efekty fabuły: wizualny (dramatyczny) i werbalny (narracyjny)}

Wychodząc od przywołania tezy, jaką stawia Richard Meek w pracy Narrating the Visual in Shakespeare (2009), że „Szekspir interesuje się estetyczną, a nawet filozoficzną zdolnością języka do przekonywania jego odbiorców - i być może także czytelników - iż znajdują się w obecności opisywanych rzeczy" (11), rozpoczynam analizę złożonej i niejednoznacznej pod względem organizacyjnym fabuły Hamleta. Przez organizację utworu należy rozumieć taki układ zdarzeń w świecie przedstawionym, który wyróżnia elementy wizualne i werbalne $\mathrm{w}$ tragedii. Ważna z punktu widzenia efektów fabuły staje się swoista gra pomiędzy narracyjnymi a teatralnymi formami reprezentacji, między językiem a przedstawieniem. Swoją tezę Meek argumentuje spostrzeżeniem, że sztuki Szekspirowskie niejednokrotnie generują „obrazowe opisy” (2009: 25). To zaś może sugerować, że dramaturg wahał się w kwestii względnych walorów języka i przedstawień, a mianowicie ich skuteczności przekonywania odbiorców: publiczności, widzów i czytelników, iż znajdują się w obecności zdarzeń świata reprezentowanego w sztuce (25). Odpowiednia manipulacja postrzeganiem zmysłowym bohaterów skutkuje wprowadzeniem w stan dezorientacji odbiorców sztuki.

Warto również przypomnieć, że w dramacie występuje narracja z bogatą fokalizacją, uzupełniona relacjami z tego, co rozgrywa się poza sceną. Nie należy przy tym zapominać, że Hamlet to widowisko, czyli pojawiające się na bieżąco zmiany wizualne (kreowane na scenie lub w wyobraźni czytelnika). Innymi słowy, jest to unaoczniona, rozgrywająca się akcja. Jeśli wziąć pod uwagę relacje między elementami wizualnymi a werbalnymi, to pierwsze, albo pasują, albo nie przystają do proponowanej wersji zdarzeń, która płynie z ust danego bohatera. 0 ewolucji w zastosowaniu przez Szekspira swoistej gry pomiędzy światem reprezentowanym na scenie i światem wyłaniającym się z relacji poszczególnych bohaterów pisze Krystyna Kujawińska Courtney w pracy "Th' Interpretation of the Time”: The Dramaturgy of Shakespeare's Roman Plays (1993). Na przykładzie dramatów Juliusz Cezar, Antoniusz i Kleopatra oraz Koriolan autorka udowadnia, jak Szekspir w strategiczny sposób eksperymentuje z mimesis i diegesis, niejednokrotnie wprowadzając konflikt między nimi. W rezultacie - jej zdaniem - sztuki te zyskują charakter „sztuk problemowych" (1993: 7). Badaczka zwraca także uwagę na możliwość manipulowania odbiorcami przez zastosowanie opozycji mimesis/diegesis, co w przypadku ostatniej z omawianych przez nią sztuk, Koriolana, skutkuje pozbawieniem widzów pewności w zakresie „stałych wartości moralnych” (1993: 130). Dostrzeżone przez Kujawińską Courtney rozbieżności między wizualnym a werbalnym efektem fabuły omawianych przez nią dramatów, 
wskazują nie tylko na coraz odważniejsze podejście Szekspira do tych kategorii, ale również pozwalają na umiejscowienie Hamleta na „osi eksperymentów" dramaturga.

Wykorzystany przez Szekspira zabieg, polegający na takim zmontowaniu fabuły, by elementy wzrokowe i słuchowe raz współpracowały ze sobą, a innym razem zaprzeczały sobie nawzajem, przyczynia się do uznania przeze mnie Hamleta za sztukę o niebezpiecznym potencjale percepcyjnym. Pomieszanie zmysłów Ofelii można uznać za dowód na to, że z konstrukcji sztuki, opartej na manipulacji zmysłami bohaterów i doprowadzającej do ich skrajnych zachowań sensualnych, wyłaniają się reprezentacje zmysłów, w szczególny sposób mogące oddziaływać na odbiorcę dramatu. Z jednej strony, stan dezorientacji w świecie przedstawionym pokazuje, jak fikcyjne postaci gubią się w labiryncie wrażeń i doświadczeń zmysłowych. Z drugiej zaś - wpływa on na percepcyjne ustosunkowanie się do sztuki przez „wodzonych za nos” (czy może precyzyjniej - „za oczy i uszy”) odbiorców. Mogą oni powątpiewać bądź zawierzyć stanom postrzegania zmysłami, w jakich pogrążają się poszczególni bohaterowie dramatu.

W opinii R. Rawdona Wilsona sztuki Szekspira zawierają stronę narracyjną, której celem jest między innymi przerwanie akcji dramatycznej i wprowadzenie nowego wątku z innego czasu i miejsca (1996: 18). W interesujący sposób komentuje on podkreślenie znaczenia percepcji słuchowej przy odwołaniach do elementów i efektów narracyjnych w sztukach:

Istnieje wiele odwołań do narządu słuchu. Zawsze jednak wskazują one, że Szekspir jest świadomy tego, iż pomyślność narracji zależy od [podatności] ucha słuchacza, nie zaś od sposobu wypowiedzi narratora. Dlatego prawie wcale nie jest zaskakujące, że rola słuchacza [odbiorcy dzieła] albo adresata opowieści [postaci fikcyjnej] [...] pozostaje aż tak istotna (1996: 27).

Ponadto badacz zaznacza, że każdą z tragedii rozpoczyna „niejednoznaczna opowieść" o decydującym wpływie na przebieg pierwszej sceny, aż po wstrząsający finał (27). Podając za przykład Hamleta, utrzymuje on, że pojawiający się w pierwszej scenie efekt narracyjny kształtuje dalszy ciąg wydarzeń. Spektakularne przybycie ducha zyskuje dodatkowy wymiar dzięki narracji. Duch żąda, by syn z powagą wysłuchał jego słów, sugerując jednak, że nie wolno mu ujawnić treści opowiadania, bo „najmniejsze słowo spustoszenie sprawiłoby" (1.5.807-809) u słuchacza. Z dalszego fragmentu wynika, że opowieść nie jest przeznaczona dla uszu żyjących, dlatego musi zostać przemilczana. Duch króla decyduje się na wyjawienie przyczyny swojej śmierci - trucizny wlanej mu do ucha. Historia ta powraca w wielu miejscach sztuki. Wilson stoi na stanowisku, że wspomniana wyżej, nieopowiedziana historia odbija się echem w Hamlecie, kiedy pojawia się 
niemożliwość przewidywania, problem z rzeczami pewnymi, zakładanie iluzorycznych masek, które w odgrywanych przez aktorów sytuacjach ukrywają rzeczywistość i nie ujawniają prawdy. [W dodatku owa historia powraca, gdy daje o sobie znać] szczególnie intensywny horror vacui, dotyczący niewyrażonych historii, próżnia narracyjna oraz nagła potrzeba opowiedzenia tego, co może być opowiedziane (1996: 27).

Komentując rolę narracji w dramatach Szekspira, autor artykułu powołuje się na renesansową koncepcję narracji, która przewidywała różnorodne i dające się dopasować do sytuacji narzędzia służące uzewnętrznieniu myśli fikcyjnych postaci. Jako środek opóźniający i utrudniający odkrycie prawdy albo przeciwnie - rzucający nowe światło na przebieg zdarzeń, narracja zajmuje centralną pozycję w rozwoju dramaturgii $(29)^{7}$. Niejednokrotnie wymiar narracyjny sztuki decyduje o jej wymiarze teatralnym. W Hamlecie żadna z opowieści nie pozostaje bez konsekwencji dla przebiegu akcji, dowodząc, że wpływ na percepcję słuchową poprzez manipulowanie słowami ma niebanalne znaczenie.

Inne podejście reprezentują Carol Banks i Graham Holderness - autorzy artykułu „Mine Eye Hath Play'd the Painter”, którzy twierdzą, że Szekspir wiele wniósł do sztuk wizualnych,

ponieważ pierwotnie wybranym przez niego medium była audiowizualna sztuka dramatyczna, w której tekst przeistacza się w dźwiękowe widowisko dla zgromadzonych - słuchających obserwatorów, „audytorium widzów”. Dla Hamleta „celem sztuki aktorskiej” było naśladowanie życia poprzez wyobrażenie sobie moralności: „podawać niejako zwierciadło naturze, pokazywać cnocie jej własne rysy, sromocie jej własne oblicze” [3.2.257-260], zaś inscenizacją zaprojektowaną, by zilustrować tę doktrynę, jest pantomima - jawne naśladownictwo, czysta wizualna reprezentacja, pozbawiona słów $(2000: 454)^{8}$.

Celem badaczy jest odejście od analizy skoncentrowanej na werbalnym wymiarze tekstu w kierunku uwypuklenia wizualnej natury dramatów Szekspira, z naciskiem na wzrokowy element kultury percepcyjnej czasów wczesnonowożytnych. Swoje podejście nazywają oni „wizualnie wrażliwym” (470). Powołują się na sformułowanie Maurice Charney z pracy Shakespeare's Roman Plays: The Function of Imagery in the Drama (1961), że ludzie uczęszczający do teatru w czasach Szekspira posiadali „obraz-świadomość”. To z kolei wiązało się z umiejętnością metaforycznego odczytywania rzeczywistości, szczególnie symboli i emblematów (2000: 455). Chodzi również o popularne w tamtym okresie emblematyczne książki, które „mówiły obrazami” (455), mające podobną właściwość poruszania percepcją wizualną jak sztuki Szekspirowskie.

\footnotetext{
${ }^{7}$ Nie jest moim celem zagłębianie się w renesansową koncepję narracji, dlatego tylko dość pobieżnie wspominam o niej w tym miejscu.

${ }^{8}$ Autorzy korzytają z The Tragedie of Hamlet, cytowanej z The Norton Fascimile: The First Folio of Shakespeare, red. Charlton Hinman (London and New York: W. W. Norton, 1968, $2^{\text {nd }}$ edn, 1996), II. 1868-1871.
} 
Banks i Holderness wspominają ponadto o innym rodzaju obrazów - przywoływanych w wyobraźni przez sztukę rozgrywającą się na scenie. Owe mentalne wyobrażenia są postrzegane wewnętrznie, niczym Hamletowskim „okiem umysłu”. Badacze określają je jako „obrazowe i malarskie”, gdyż mogą zostać one zmaterializowane w postaci malowidła czy rzeźby (2000: 456). Są jak gdyby „zapożyczane spoza dramatu” (456) i pojawiają się jako obrazy mentalne. Oddziaływanie na zmysły tekstem-przedstawieniem powoduje - zdaniem badaczy - że obrazy są „[w]yobrażane w procesie oglądania przedstawienia albo przywoływane $\mathrm{w}$ pamięci $\mathrm{w}$ następstwie mnemonicznych obrazów i dźwięków (czy to cytowanych słów, czy też utrwalonych wizualnych symboli)" (2000: 456). Dodatkowo pewne obrazy postrzegane wewnętrznie stanowią ekfrazy, będąc rozbudowanymi metaforami lub epizodami rozgrywającymi się poza sceną, jak na przykład utonięcie Ofelii (456). Liczne malarskie wizerunki tej postaci świadczą o tym, że istnieje możliwość, by „odzyskać wizualną zawartość z nośnika werbalnego, który przekazuje ją do zewnętrznego ucha i wewnętrznego oka widza" (456).

Z kolei zdaniem Meeka, siłą napędową akcji dramatu jest ciągła konfrontacja pomiędzy werbalnym przekazem na poziomie sztuki a wizualną stroną toczącej się akcji. Jak podaje badacz:

\footnotetext{
Sztuka wydaje się wskazywać, że widzenie i słyszenie - oraz dodatkowo narracja i dramat - są wzajemnie zależne, przy czym żadne nie jest potraktowane priorytetowo. Hamlet nie jest więc po prostu antyteatralny, ale raczej wydaje się eksperymentować z zależnościami pomiędzy różnymi sposobami mimesis (2009: 114).
}

Z konstrukcji fabuły tragedii płyną wnioski dotyczące zarówno charakteru dramatu, w którym przeplatają się elementy narracyjne ze scenicznymi, jak i refleksje na temat celowości zastosowania określonej organizacji tekstu przez Szekspira. Być może dramaturg poprzez zamierzoną niejednoznaczność konstrukcyjną Hamleta włączył się nieświadomie we wczesnonowożytną debatę na temat hierarchii zmysłów w kulturze. Jest to istotny dowód na potraktowanie literackich reprezentacji zmysłów jako cennych źródeł wiedzy o kulturze percepcyjnej czasów renesansu.

\section{„Hamlet” intertekstualny, czyli zwiqzek literatury z filmem}

O doniosłości adaptacji w kulturze Zachodu wspomina Linda Hutcheon w pracy A Theory of Adaptation (2006), sygnalizując, że także Szekspir przerabiał opowieści kulturowe swoich czasów na potrzeby teatru. Tą drogą liczne przekazy kulturowe zawędrowały więc ze stronic książek na scenę teatralną (2006: 2). Potraktowanie adaptacji jako opowieści zrodzonej z innej 
opowieści (zawierającej już w sobie elementy różnych opowieści), celowo wykorzystującej wątki poprzednich dla stworzenia nowej historii sprawia, że adaptacja filmowa zapewnia ciągłość kulturowej egzystencji danej historii. Nie jest to już ta sama historia, dlatego można mówić o niezależności adaptacji jako nowego tekstu kulturowego, uzależnionego jednak od wcześniejszych adaptacji.

Robert Stam w Literature and Film: A Guide to the Theory and Practice of Film Adaptation (2005) rozważa relacje pomiędzy sztuką literacką i filmową. Przede wszystkim powołuje się na tradycyjne podejście, promujące tezę, że adaptacja, w porównaniu z pierwowzorem literackim, zajmuje drugorzędne miejsce. Badacz twierdzi, że zachodzący między nimi związek supremacji-podległości wynika z założenia, że działalnością artystyczną pierwotną w stosunku do filmu była literatura. Stam mówi nawet o „starszeństwie” (2005: 4) dzieła literackiego i „podwładnym statusie” (4) adaptacji (i obrazu). Jeśli chronologicznie oceniać materiały kulturowe, to nie ma wątpliwości, że zgodnie z taką logiką "czcigodna” (4) literatura staje się nadrzędna wobec młodszej rangą sztuki filmowej (4). Wskazując na rywalizujące aspekty funkcjonowania literatury i filmu, autor określa młodsze medium jako „nowobogackiego nieprzyjaciela, atakującego wały obronne literatury” (4). Badacz odwołuje się do współczesnej kondycji kultury w kontekście współzawodnictwa między znakami pisma a obrazami filmowymi o pozyskanie odbiorców. Jego zdaniem, „[f]ilmowe ucieleśnienie uważa się za powód, dla którego literatura staje się przestarzała, odsłaniający jedynie słowa z jakiegoś powodu słabe, widmowe i niematerialne" (4).

Jeśli chodzi o poziom generowania obrazów poprzez oddziaływanie przekazu werbalnego i wizualnego, Stam wyróżnia dwie orientacje: ikonofobiczną i logofiliczną. Pierwsza wyraża wrogie nastawienie w stosunku do obrazów, druga zaś promuje słowo jako podstawowy i nadrzędny środek komunikacji. Jeśli odnieść owe stanowiska do nastawienia tradycyjnych teoretyków filmu i literatury, wówczas okaże się, że adaptacja zagraża pierwotnemu przekazowi słownemu swym wizualnym, uwodzącym widza przekazem.

Kolejną kwestią poruszoną przez badacza jest antykorporalizm, będący ujęciem krytykującym ucieleśniającą siłę filmu. Chodzi tu między innymi o „nieuchronną materialność” filmu, „ucieleśnionych” aktorów, „realne miejsca akcji” oraz o powodowanie „wewnętrznych wstrząsów systemu nerwowego" (2005: 6). W porównaniu z obrazem filmowym, tekst literacki „jest przekazywany na wyższym, bardziej intelektualnym, transsensualnym i pozacielesnym poziomie" (6). Stam przywołuje stwierdzenie, że inaczej niż literatura, czytana „okiem umysłu”, film „bezpośrednio angażuje różne zmysły" (6). Sam jednak uważa, że oba środki przekazu stanowią czysto mentalne procesy, z tą różnicą, że dzieło literackie „nie jest dosłownie oglądane poprzez obiektyw, nie jest projektowane na ekranie ani odbierane słucho- 
wo na poziomie dźwięków mierzonych w decybelach; dźwięków które mogą spowodować pęknięcie szyby albo zniszczenie bębenków słuchowych" (6).

By zdystansować się od tradycyjnej krytyki adaptacji filmowej, Stam proponuje zastosowanie kategorii intertekstualności. Podobne podejście prezentuje Palmer, który uważa, że „[j]akiekolwiek rozważania nad filmową adaptacją oznaczają mówienie o jednym tekście i jednocześnie mówienie o innym" (2005: 3). Dlatego zestawienie materiału literackiego z materiałem filmowym warto rozpocząć od uświadomienia sobie czasowej przepaści dzielącej oba wytwory kulturowe. Przy założeniu, że nie istnieje oryginał Hamleta nie tylko ze względu na brak rękopisu, ale głównie z powodu intertekstualnego charakteru samej sztuki, każde kolejne „ożywienie” Hamleta w postaci adaptacji filmowej składa się na historię powiązań pomiędzy Hamletem wczesnonowożytnym a Hamletem postmodernistycznym. Jeśli przyjąć, że każdy materiał kulturowy jest mozaiką złożoną z poprzednich, to zarówno Hamlet wczesnonowożytny, jak i ten postmodernistyczny, mają sporo „do powiedzenia" w kwestii zapożyczeń sensów i reprezentacji zmysłów. Choć tak samo wersja literacka dzieła, jak i jego adaptacje pochodzą z różnych okresów jako produkt odmiennych kultur percepcyjnych, ostatecznie następuje wymiana i negocjacja znaczeń, w wyniku której pojawia się wytwór palimpsestowy. 


\section{Zmysły w teatrze, filozofii i medycynie w okresie wcze- snej nowożytności}

\section{„Miejcie oczy i uszy otwarte”}

Widzenie i słyszenie spełniają wiele funkcji kulturowych, między innymi warunkują poznanie, stanowią narzędzia władzy czy też są źródłami przeżywanych doznań. Kulturowy repertuar postrzegania zmysłowego, którego przejawem są na przykład społeczne sposoby wykorzystania danego organu postrzegania albo językowy obraz świata zmysłów z minionych epok, jest bogaty i często zaskakujący. Z jednej strony, zmysły denotują biologiczną zdolność do odbierania i analizowania bodźców, z drugiej zaś studia sensoryczne pozwalają na traktowanie zmysłów jako formacji kulturowej, podlegającej badaniom z zakresu humanistyki i nauk społecznych. W opinii Jütte: „»[e]konomia zmysłów « jest lustrzanym odbiciem danego społeczeństwa, co znaczy, że w jakiejkolwiek przyjętej hierarchii czy klasyfikacji zmysłów można dostrzec kontury umysłowości oraz kopie dołączonej do nich hierarchii społecznej i systemu wartości" (2005: 14).

Zarówno wzrok, jak i słuch były zazwyczaj uważane za najwyżej usytuowane zmysły w ich hierarchii, przy czym to wzrok najdłużej zajmuje „coś w rodzaju hegemonistycznej pozycji w kulturze Zachodu” (Smith, 2004: 19). W konsekwencji znaczenie wzroku sprowadza się do sprawowania przezeń wielowiekowej „przywódczej roli” w imperium zmysłów. W dużym uproszczeniu przyjmuje się, że od początków ery nowożytnej widzenie i jego społeczno-kulturowe przejawy znalazły się w centrum zainteresowań wielu dziedzin ludzkiej działalności, takich jak: teatr, medycyna, astronomia czy też filozofia. Nie ma to związku jedynie z biologiczną funkcją wzroku jako dominującego zmysłu u człowieka, ale również z kulturowymi implikacjami wykorzystania percepcji wizualnej, które przekraczają społeczne zastosowanie innych zmysłów.

Porównując funkcjonowanie percepcji wizualnej i słuchowej, Hall dochodzi do wniosku, że: 
Docierające dane słuchowe są doświadczane jako mniej charakterystyczne niż dane wzrokowe. Bardziej niż wzrokowych wydaje się nam potrzebne przeprowadzenie w umyśle syntezy informacji słuchowych. To znaczy, że jesteśmy bardziej świadomi powiązania pomiędzy tym, co dzieje się wewnątrz, a bodźcem wywołującym ten wewnętrzny proces. Dystans pomiędzy widoczną i niewidoczną treścią muzyki (i mowy) jest mniejszy niż w przypadku widzenia. W konsekwencji słuch ma możliwość głębszej spójności na poziomie empiryczności. Krótko mówiąc, jest poniekąd bardziej osobisty (1986: xvi).

Wzrok zaś w największym stopniu determinuje ludzkie postrzeganie zmysłowe i najbardziej znacząco wpływa na naszą wiedzę o świecie. Naukowo udowodnionym faktem jest to, że oczy w bardzo efektywny sposób gromadzą i transmitują wiedzę o rejestrowanej zmysłami rzeczywistości. 0 randze wzroku w kulturze świadczy nagromadzenie wyrażeń językowych odnoszących się do widzenia. Fenomen ludzkiego postrzegania wzrokowego w sposób niezwykle dobitny oddaje sfera lingwistyczna, porządkująca nasze myślenie. Myślenie zorganizowane wokół percepcji sensorycznej faworyzuje wzrok i ustanawia hierarchię zmysłów w kulturze. Odczuwanie zmysłami przekłada się więc $\mathrm{w}$ dużym stopniu na zarządzanie kulturą i jej kształtowanie poprzez język. Dlatego tak istotny staje się zapis przeżyć i praktyk sensualnych z minionych wieków, znajdujący odzwierciedlenie w literaturze ${ }^{1}$.

W pracy Ciało, strój i gest w czasach renesansu i baroku (1996) Hanna Dziechcińska przypomina o tym, że ludzie z różnych epok odbierali (w podobny sposób w znaczeniu biologicznym, a jednak inny, gdyż uwarunkowany kulturowo)

zarówno sygnały wizualne istniejące w sensie przyrodniczym, ogarniające całość widzialnej rzeczywistości danej przez naturę, jak i sygnały wizualne, w pewnym sensie wyselekcjonowane, których bodźce zostały wytworzone, uporządkowane oraz dane w formie zorganizowanej, zaaranżowanej, inscenizowanej, bądź też w pewnych przypadkach - opatrzone wyjaśnieniem i interpretacją (8).

W przypadku sygnałów wyselekcjonowanych i przedstawionych na przykład w formie architektonicznej lub zaprezentowanych pod postacią obrazu czy przedstawienia teatralnego, ich oddziaływanie na percepcję wizualną zdaje się specyficznym rodzajem wywierania wpływu na zmysł wzroku. Obcowanie ze sztuką jest bowiem zwróceniem uwagi na wybrany fragment rzeczywistości stworzonej przez człowieka. Jeśli za taki uznać świat przedstawiony w Hamlecie, to z języka Szekspira wyłaniają się reprezentacje zmysłów, które z kolei oddziałują na zmysły czytelnika, zarówno wymiarem narracyjnym, jak i widowiskowym. Wzrok i słuch stają się szczególnie zaangażowane w interpretację dramatu. Ten zaś angażując zmysły, sam jest uwikłany we właściwe tylko jemu „życie percepcyjne”.

\footnotetext{
${ }^{1}$ Nie należy zapominać o tak ważnych dziedzinach, jak architektura, malarstwo czy rzeźba, które wyrosły głównie z ludzkiego doświadczenia wizualnego.
} 
Biorąc pod uwagę rozpiętość czasową pomiędzy współczesnością i czasami Szekspira, porównanie praktyk percepcyjnych (społecznego i kulturowego wykorzystania zmysłów) tych dwóch okresów i określenie charakteru owych epok pod względem dominacji danego zmysłu nad innymi, jest zadaniem obciążonym perspektywą prezentystyczną oraz tendencją uogólniającą. Trzeba pamiętać, że współczesne „okulary percepcyjne” determinują sposób, w jaki zdobywamy wiedzę o sensualnym życiu, wartościach i praktykach ludzi żyjących w renesansie. Jeśli uwzględnimy takie obciążenie perspektywiczne oraz nieuniknioną generalizację $w$ badanym temacie, wówczas łatwiej też będzie pogodzić się z różnorodnością poglądów odnoszących się do przeszłego oraz teraźniejszego, kulturowo uwarunkowanego świata zmysłów.

Według Marka Robsona poglądem powszechnie akceptowanym przez badaczy renesansu jest punkt widzenia uznający, że we wczesnonowożytnej Anglii dominowała kultura słowna. „Skąd [badacze] wiedzą, że była to kultura słowna?" - pyta Robson w artykule „Looking with Ears, Hearing with Eyes: Shakespeare and the Ear of the Early Modern". Autor, jakby w odpowiedzi, stara się nieco skomplikować omawiany model poprzez zwrócenie uwagi na element wizualny tej kultury, ujawniający się na poziomie pisma podczas praktyk głośnego czytania. Badacz podaje, że „[o]dczucia związane z aktywnością ucha i głosu pochodzą z obcowania z tekstami, które pierwotnie są postrzegane przez oko” („Looking with Ears”). To, co z pozoru wydaje się związane ze zmysłem słuchu, okazuje się nie tak oczywiste dla Robsona, który pokazuje dwoistą naturę spektakli teatralnych. Jeśli wziąć pod uwagę sposób, w jaki „widzowie-słuchacze” odbierali sztuki w czasach elżbietańskich, można dojść do wniosku, że tekst dramatyczny musiał być częściowo zanurzony w nadal obecnej w renesansie tradycji słownej oraz po części w rodzącej się kulturze pisma. Chodzi tu o odbiór tekstu mówionego na scenie, pierwotnie istniejącego $\mathrm{w}$ formie pisanej. Teatr stał się zatem miejscem spotkania pomiędzy dwoma wymiarami języka: werbalnym i wizualnym. Uczestnicy spektaklu, składający się zarówno z tych, którzy jeszcze nie otrzymali edukacji, jak i z tych, których można określić jako piśmiennych, stanowili widownię o niejednorodnych „preferencjach zmysłowych”. Stąd też umiejętność zapoznania się z tekstem przez aktorów wymagała odpowiedniej artykulacji, przemawiającej do widowni „patrzącej uszami i słuchającej oczami”. Robson zmierza do przełamania wielokrotnie przytaczanej w badaniach nad kulturą renesansową opozycji mowy i pisma, które, jego zdaniem, zamiast zwalczać się - wzajemnie na siebie oddziaływały.

Zwolennikiem poglądu o istotnym wpływie słowno-słuchowego wymiaru kultury wczesnego renesansu na powstawanie sztuk teatralnych jest Robert Weimann. W artykule „Mimesis in Hamlet” (1985) wysuwa on następujące twierdzenie na temat dzieł Szekspira: „Mimo faktu, że sztuki wiele zawdzięczają humanistycznej poetyce języka pisanego, to jednak pozostały 
bliskie kulturze głosów, cywilizacji znaków mówionych i praktycyzmowi, który nawet ślepcowi (oraz nieoczytanemu widzowi) nakazywał, by "patrzył swymi uszami«" (276). W Author's Pen and Actor's Voice. Playing and Writing in Shakespeare's Theatre (2000) Weimann dokonuje natomiast podziału na „pióro autora” i „głos aktora”, na pisanie i mówienie, w celu zanalizowania praktyk przedstawień teatralnych w czasach elżbietańskich. Jak zauważa: „W rzeczywistości niespokojny stan współistnienia »pióra autora« i »głosu aktora« był zarówno nieodłączny od niestabilnej kondycji samego tekstu, jak i rozproszonych praktyk przedstawień" (2000: 9). Weimann mówi o wzajemnym oddziaływaniu na siebie tekstu (autora) i gry aktorskiej (aktora), co przekłada się choćby na uznanie pisma i mowy za dwie odmienne formy komunikacji skazane na współpracę (10).

Z kolei Gabriel Egan, autor artykułu „Hearing or Seeing a Play? Evidence of Early Modern Theatrical Terminology", porusza problem wczesnonowożynego uczestniczenia w przedstawieniach teatralnych jako doświadczenia bardziej wzrokowego albo bardziej słuchowego (2001: 326). Egan powołuje się na prace innych badaczy tego zjawiska, spośród których jedni utrzymują, że przy odbiorze dominował zmysł słuchu oraz że publiczność składała się ze słuchaczy raczej niż z widzów, inni zaś dowodzą, że utrzymywało się napięcie pomiędzy pojmowaniem teatru jako widowiska i teatru jako słuchowiska (327). Na podstawie własnych badań, polegających na ilościowym zestawieniu zwrotów „oglądać sztukę” lub „słyszeć sztukę”, użytych przez wybranych pisarzy, poetów i dramaturgów, których dzieła powstały w okresie 15501650 (329), badacz dochodzi do wniosku, że „w literackich i dramatycznych pismach tego okresu sztuki częściej traktowano jako doświadczenie wizualne niż słuchowe” (332). Autor wyjaśnia, że „prawie połowa rzadkich słuchowych przykładów należy do Szekspira i można zgadywać, iż jego przewaga na tym polu jest powodem, dla którego niezwykły sposób ujmowania tego [zjawiska] przez Szekspira został błędnie wzięty za normę w tym okresie" (332).

Zbliżoną kwestią zajmuje się Andrew Gurr w pracy Playgoing in Shakespeare's London (2004). Autor skupia się na różnicach pomiędzy odbiorem sztuk w czasach Szekspira a współczesnym statusem odbiorcy przedstawień. Biorąc pod uwagę rozbieżności pomiędzy kulturami percepcyjnymi tak odległych od siebie okresów, ewolucja w postrzeganiu zmysłowym wydaje się nieunikniona. Gurr rozważa kwestię odbioru sztuk w czasach Szekspira od strony oddziaływania przedstawień na zmysły. Zastanawia się, czy ludzi, którzy chodzili na przedstawienia teatralne, można określić jako „słuchaczy” czy „widzów” (2004: 102). Badacz odnosi się do angielskiego słownictwa z zakresu uczestnictwa w przedstawieniu, twierdząc, że:

W języku angielskim brakuje odpowiedniego słowa dla uczty zmysłowej, której powinno dostarczyć chodzenie do teatru. Tę nieścisłość odzwierciedlają wyrażenia określające 
uczestników przedstawień teatralnych. Słowo „audytorium” posiada znaczenie wyniesione z sądownictwa, a mianowicie „przesłuchanie”. Określenie „widownia” ma związek z meczami futbolowymi, podczas których narząd wzroku odbiera więcej informacji niż narząd słuchu. Nie ma angielskiego określenia, które potwierdzałoby pełne doświadczenie słuchania i oglądania całej „akcji” sztuki. Ponadto „audytorium” zakłada istnienie tłumu, podczas gdy widz jest indywidualnością. Siła emocjonalna, która dzieli tłum, jest potężniejsza, ale znacznie trudniej ją uchwycić niż osobisty odbiór sztuki (2004: 102).

W innym miejscu Gurr odnosi się do tych cech przedstawień teatralnych, które akcentują wpływ na percepcję wzrokową. Wymienia tu przede wszystkim unaocznienie akcji przedstawienia, ruch sceniczny, podkreślone za pomocą kostiumów wcielanie się aktorów w role, czy też pobudzające wzrok dekoracje sceny. Takie podejście do przedstawień powinno spowodować, że w teatrze

widz z łatwością zastąpiłby słuchacza. Jeśli jednak przyjmiemy to założenie, musimy pominąć nie tylko fakt, że „audytorium” przetrwało jako standardowe słowo, ale także zignorować znacznie większą gotowość elżbietan do wykorzystania percepcji słuchowej do opanowania wszelkich form wiedzy (2004: 107).

Nie ulega wątpliwości, że przekaz sztuki w dużym stopniu zależał od aktorskich umiejętności opanowania tekstu. Werbalne strategie, zakorzenione w społeczeństwie niepiśmiennym, jak na przykład słuchowe praktyki mnemoniczne oparte na grze słów, oznaczały odmienne od nam współczesnych sposoby nauki. Zdaniem Marcus, scenę, w której Hamlet spotyka się z aktorami przed odegraniem przez nich sztuki, można odczytać jako Szekspirowskie potwierdzenie renesansowych praktyk uczenia się tekstu przez aktorów przed wystawieniem. Książę sugeruje, co i jak powinno być powiedziane w trakcie przedstawienia. Według Marcus sztuka-w-sztuce, czyli „Morderstwo Gonzagi", staje się spektaklem o charakterze przede wszystkim słuchowym, a nie wzrokowym (1996: 160).

W pracy Shakespeare's Reading (2000) Robert Miola zwraca uwagę na dominującą również wśród wyedukowanej części społeczeństwa elżbietańskiego wrażliwość na dźwięk, a więc na język mówiony, i związane z tą wrażliwością praktyki czytania na głos oraz rozkoszowanie się dźwiękowym wymiarem tekstów. Według Adama Foxa, autora Oral and Literate Culture in England 1500-1700 (2000), nawet ludzie niepotrafiący czytać nabywali teksty pisane w oczekiwaniu, że zostaną im przeczytane na głos przez kogoś, kto czytać potrafi (37). Jak zauważa Miola: „Elżbietańska wrażliwość słuchowa prowadziła do znajdowania przyjemności we wszelkiego rodzaju grach słownych, ripostach, dwuznacznikach, kalamburach i wybiegach słownych" (2000: 3). Co więcej, równie cenione były efekty dźwiękowe, osiągane poprzez zmiany pomiędzy partiami wierszowanymi a prozą oraz $\mathrm{w}$ ramach sa- 
mych partii wierszowanych (3). Oddziaływanie sztuk Szekspira na percepcję słuchową to mocno zakorzeniona w kulturze wczesnonowożytnej praktyka kulturowa z czasów średniowiecznych.

Praca Wesa Folkertha The Sound of Shakespeare (2002) poświęcona jest roli, jaką dźwięk odgrywał w czasach Szekspira. Badacz porusza zagadnienie percepcji słuchowej związanej ze sposobem, w jaki ludzie renesansu produkowali i odbierali dźwięki. Jak podaje Folkerth: „Szekspir za pomocą dźwięku tworzył światy, które z kolei zawierają w sobie całe krajobrazy dźwiękowe" (2002: 7). Zdaniem badacza, dźwięki wypełniające świat akustyczny epoki wczesnonowożytnej znajdują literacką reprezentację w sztukach angielskiego dramaturga, który w swoich dziełach podjął się zidentyfikowania owych krajobrazów dźwiękowych z przeszłości i nadania im nazw (albo użycia już istniejących). Sama praca ze słowem, którego jednym z wymiarów jest wymiar akustyczny, w nieunikniony sposób stanowiła podstawowy element pracy dramaturga. W opinii Folkertha ,jego [Szekspira] sztuki są produktem wcielonej świadomości, którą przenikały kulturowe podejścia i praktyki" (9). 0 znaczeniu percepcji słuchowej okresu renesansu i znaczeniu mowy w tej kulturze można jedynie wnioskować i snuć przypuszczenia, między innymi na podstawie analizy dramatów Szekspira. Badacz podkreśla, że sztuki te były pisane z myślą o wystawieniu ich w teatrze, dlatego trzeba zwracać uwagę na „tonalności zakorzenione w tych utworach”, by postarać się usłyszeć je tak, jak słyszały je „wczesnonowożytne uszy” (9).

Z kolei we wstępie pracy Reading, Society and Politics in Early Modern England (2003) Kevin Sharpe i Steven N. Zwicker zwracają uwagę na wczesnonowożytną tendencję do kreowania „ja”. W ocenie autorów, „»ja« było odkrywane we wszystkich aktach pisania i czytania" (2003: 12), a nawet nieustannie kreowane na nowo. W kulturze patriarchalnej, jaką niewątpliwie była kultura renesansu, humanistyczny program autokreacji poprzez praktyki piśmienno-czytelnicze obejmował tylko część społeczeństwa. Podział ze względu na płeć kulturową uwzględniał przede wszystkim aktywnego czytelnika płci męskiej, nierzadko z piórem w ręku, a więc „zarządzającego tekstem nie mniej niż swoim gospodarstwem", dla którego akt czytania i pisania był "dynastyczny, dominujący i falliczny” (15). Z takim obrazem kontrastuje ówczesne wyobrażenie o kobiecie jako obiekcie seksualnym, przedstawianym jako „książka, którą można otworzyć” (15). Uwikłanie w proces czytania i pisania percepcji zmysłowej powoduje, że owe praktyki można zaliczyć do kategorii narzędzi władzy. To głównie narząd wzrokowy, będąc zaabsorbowany powyższymi procesami, staje się jej zmaskulinizowanym narzędziem.

Literackie i malarskie reprezentacje ludzi renesansu z wyższych sfer akcentują obecność książek w ich codziennym życiu. Sportretowanie człowieka z książką w ręku oznaczało jego uprzywilejowaną pozycję społeczną oraz oczytanie, a stąd także wiedzę i autorytet. Jak podają Sharpe i Zwicker: 
„W kulturze protestanckiej, która wysuwa na pierwszy plan słowo, książka w interesujący sposób i całkiem dosłownie staje w centrum wizualnego zainteresowania" (2003: 16). Podobnej reprezentacji nie brakuje również w Hamlecie, w scenie, w której Hamlet przechadza się z książką w ręku i oznajmia Poloniuszowi, że znajduje w niej jedynie „słowa, słowa, słowa” (2.2.371).

Katherine A. Craik w pracy Reading Sensations in Early Modern England (2007) analizuje wpływ słowa pisanego na emocje, jakie mogło wzbudzać w renesansowym czytelniku. Przytaczając wczesnonowożytne teorie na temat związków między czytaniem i reakcjami emocjonalnymi mężczyzn i kobiet, autorka demonstruje, jak pobudzenie postrzegania u każdej z płci wywołuje odmienne stany emocjonalne. Według badaczki „we wczesnej fazie nowożytności wzmożone zainteresowanie było skierowane na sposoby fizycznego pobudzenia pisarzy i czytelników - albo podnieconych, albo poruszonych - przez tworzone bądź konsumowane przez nich książki" (2007: 3)².

Bazujący na rozróżnieniu na płeć podział przyjęty w okresie wczesnej nowożytności, opierał się głównie na humoralno-termalnym rozróżnieniu kobiet i mężczyzn. Była to teoria zapożyczona od Hipokratesa ${ }^{3}$, rozwinięta przez Galena, uznająca, że ludzkie ciało „było niespokojnym bytem, komunikującym się z otaczającym go światem, i z tego powodu było podatne na nieprzewidywalne wahania wewnątrz własnej ekonomii humoralnej" (West-Pavlov, 2006: 145). Kontrolowanie i "trzymanie w ryzach” owych płynów „nastrojowych” było uzależnione od wiedzy na swój temat, w połączeniu $\mathrm{z}$ odpowiednimi atrybutami płci. W przypadku kobiet sądzono, że są one obdarzone większym chłodem i wilgotnością ciała oraz że mają tendencję do większego pobudzenia emocjonalnego. W przeciwieństwie do mężczyzn, miały też posiadać słabszą wolę i mniej rozwinięte zdolności umysłowe. Jak zauważa West-Pavlov:

Kobietom przypisywano zmienne cechy, takie jak: nieuczciwość, niestałość, brak wytrzymałości fizycznej i samokontroli oraz niekonsekwencję. Ponadto uważano, że także macica ma niekorzystny wpływ na kobiecą racjonalność, sprawiając, że kobiety są bardziej podatne na namiętności i przemoc (2006: 145).

Ponieważ uważano, że czytanie pobudzało równie kobiety, jak i mężczyzn, rodzące się namiętności i emocje oddziaływały na wyobraźnię oraz pracę umysłu. Zmiany somatyczne i emocjonalne inaczej wyglądały u każdej

\footnotetext{
${ }^{2}$ Praktyki czytelnicze, które opisuje badaczka, przede wszystkim dotyczą mężczyzn.

${ }^{3}$ W hipokratejskiej szkole lekarskiej (ok. V-IV w. p.n.e.) powstała tzw. teoria humorów, wyjaśniająca zdrowie lub chorobę organizmu. „Humory”, czyli płyny lub fluidy znajdujące się w ludzkim organizmie, miały według tej teorii decydować o stanie organizmu. Jeśli doszło do zaburzenia w równowadze między czterema podstawowymi fluidami: krwią, cholerą (żółcią), flegmą i melancholią, organizm ludzki reagował w sposób patologiczny (Porter, 2003: 49-52).
} 
z płci. Reakcja czytelnicza stanowiła o męskim albo kobiecym sposobie odbioru tekstu. Zaświadczała także o stanie psychofizycznym jednostki (Craik, 2007: 4). Podobny temat porusza Adrian Johns w rozdziale książki The Nature of the Book. Print and Knowledge in the Making, zatytułowanym „The Physiology of Reading". Badacza interesuje zagadnienie doświadczenia czytelniczego ludzi żyjących na przełomie XVI i XVII wieku. Doświadczenia te opisywano za pomocą znanych ówcześnie namiętności, czyli „emocjonalnych, fizjologicznych i moralnych reakcji ludzkiego ciała na otoczenie", w tym na proces czytania (1998: 386).

Pojawienie się pisma drukowanego w kulturze Zachodu „z(r)ewolucjonizowało" także ludzkie sensorium, wpłynęło zwłaszcza na kulturowe sposoby wykorzystania wzroku. Badacz stawia trzy fundamentalne pytania: „Co we wczesnonowożytnej Anglii znaczyło »widzieć«? oraz „Gdy używano zmysłu wzroku, co faktycznie przechodziło przez powietrze do/w kierunku oka”, a także „W jaki sposób to [coś] wywoływało efekt, gdy już się tam dostało?” (1998: 387). Johns przywołuje stwierdzenie Patricka Collinsona, który zasugerował, że owe pytania rzeczywiście są tymi, które powinny zainicjować wyjaśnianie funkcjonowania kultury protestanckiej Anglii (387). By opisać charakterystyczne dla czasów renesansowych procesy percepcyjne zaangażowane w czytanie, można było odwołać się do licznych dyskursów na ten temat, począwszy od dyskursu codziennej medycyny, przez kazuistykę i nauki moralne głoszone przez pastorów, po specjalistyczną wiedzę i praktykę anatomiczną.

$\mathrm{Z}$ kolei w pracy Rhetoric, Women and Politics in Early Modern England (2007) Jennifer Richards i Alison Thorne udowadniają, jak ograniczony dostęp kobiet do edukacji w czasach renesansu przyczynił się do rozwoju odmiennych form posługiwania się językiem. Chodzi tu przede wszystkim o nauczanie retoryki, do której opanowania zachęcano głównie chłopców i mężczyzn. Poprzez wpływanie na percepcję wzrokową i słuchową w szkołach przekazywano męskiej części społeczeństwa wiedzę na temat retorycznych form wypowiedzi, czyli „zestawu zasad, spisu narzędzi, które racjonalizują akt »należytego« albo przekonującego wypowiadania się" (2007: 2). Ponieważ studiowanie retoryki wiązało się w dużej mierze ze studiowaniem łaciny, stała się ona językiem wykształconych mężczyzn. Badaczki opisują proces szkolenia w zakresie retoryki, rozpoczynający się od rozpoznawania prostych zasad syntaktycznych w łacinie, aż po skomplikowane gramatycznie konwersacje, wywołujące „efekt retoryczny” (3). Oddziaływanie na narząd słuchu stanowiło jeden z podstawowych celów sztuki retoryki. Zawładnięcie percepcją słuchową rozmówcy traktowano jako cenne narzędzie manipulacji, wykorzystywane w życiu codziennym. W praktyce, jak podają autorki książki: „Dzięki szkoleniom retorycznym wytwarzane były otwarte i elastyczne umysły. Powstała generacja funkcjonariuszy państwowych, doradców i »wysłan- 
ników«, którzy opanowali sztukę przemyślanego krasomówstwa; mężczyzn, którzy byli językowo przygotowani, by nakłonić innych do działania" (3).

Z kolei o liminalnej kulturze wczesnej nowożytności w ciekawy sposób pisze Fox, twierdząc, że była to kultura, w której można odnaleźć

różnorodność doskonale funkcjonujących alternatyw dla sporządzania zapisów lub prowadzenia rejestrów za pomocą pióra i papieru, gdzie większość przedstawień była improwizowana i spontaniczna oraz gdzie najistotniejsza wiedza była przekazywana z wykorzystaniem przykładu i naśladownictwa. Wielu nie potrafiło czytać, a umiejętność ta niewiele dla nich znaczyła. Niemniej jednak nawet świat niepiśmienny nie był odporny na wpływ słowa pisanego i drukowanego. Do pewnego stopnia było tak nawet przed okresem renesansu, ale to właśnie w czasach wczesnonowożytnych rosnące wykorzystanie pisma w niemalże każdej sferze życia, połączone z wpływem druku, niezwykle przyspieszyło proces rozmiłowania się w literaturze (2000: 36).

Fox uważa, że środowisko, w którym przyszło egzystować ludziom okresu renesansu, było piśmienne, stąd wniosek, że nie mogli oni uniknąć pewnego kontaktu ze słowem pisanym, jak na przykład słuchanie tekstu odczytywanego z Biblii czy też powtarzanie słów istniejących w formie zapisu (37). Wzajemne relacje pomiędzy późnoakustycznym i wczesnowizualnym wymiarem kultury renesansu sprowadzały się w dużej mierze do tego, że choć przekazy słowne nadal były najbardziej popularną i bezpośrednią formą przekazywania informacji, to repertuar werbalny nie pozostawał bez wpływu na słowo pisane (43). Skutkiem oddziaływania na percepcję słuchową i wzrokową poprzez różne formy komunikacji językowej było wytworzenie „dynamicznego kontinuum”, w ramach którego mowa i pismo „dostarczają i odbierają sobie strawę ku rozwojowi i posileniu każdego" (50).

\section{Od teorii do praktyki i z powrotem}

Za istotny oraz użyteczny element poprzedzający analizę zmysłów w dramacie Hamlet uznałam teorie opisujące renesansowe podejście do zmysłów. Owo podejście stanowi podstawę teoretyczną ułatwiającą zrozumienie, a czasem nawet wyjaśniającą podejście do świata zmysłów, jakie, (jak się wydaje), Szekspir mógł podzielać nie tylko dzięki znajomości praktyk społecznych, ale także wiedzy powszechnej oraz naukowej, dostępnej ludziom w tamtych czasach. Będąc zanurzonym w pewnej kulturze percepcyjnej, dramaturg z pewnością nie mógł pozostać bez jej wpływu na własną twórczość.

Na konceptualne ujęcie zmysłów w czasach wczesnonowożytnych składają się, między innymi, następujące kwestie: hierarchia zmysłów, liczba zmysłów, relacje między poszczególnymi organami percepcyjnymi, ich anatomiczne funkcje, rola zmysłów w poznaniu oraz związek percepcji z pozy- 
skiwaniem wiedzy o świecie zewnętrznym i wewnętrznym. Wymienione powyżej elementy tworzyły wspólnie zestaw kluczowych dylematów ówczesnej teorii sensorycznej, opisującej funkcjonowanie zmysłów. Ponadto problematyka związana z percepcją zmysłową zazębia się z ówczesną dyskusją na temat podmiotowości, ucieleśnienia i ludzkiej tożsamości społeczno-kulturowej.

Kształtująca się w czasach Szekspira kultura percepcyjna przejęła tradycję pięciu zmysłów - kanonu pochodzącego z okresu starożytnego oraz średniowiecznego (Classen, 2001: 358-359). Ustanowienie całkowicie odmiennej hierarchii zmysłów okazało się niemożliwe ze względu na siłę oddziaływania wcześniejszych ideologii i praktyk percepcyjnych oraz możliwość ich zmodyfikowania i zaadaptowania do nowych warunków kulturowych. Istotną rolę w kształtowaniu renesansowej „drabiny zmysłów” odegrały zwłaszcza poglądy filozoficzne i medyczne tego okresu. Zarówno traktaty filozoficzne, jak i medyczne, pokazują ówczesne zapatrywania na świat zmysłów. Jednocześnie spełniają one funkcję ideologiczno-twórczą, same wpływając na sposób postrzegania zmysłów. Filozofia renesansowa przyswoiła sobie wcześniejsze koncepcje dotyczące najwyżej sytuowanych zmysłów, czyli wzroku i słuchu. Według tradycyjnego podziału można wyróżnić zmysły typowo korporale, czyli dotyk, węch i smak, oraz zmysły mentalne, do których należą wzrok i słuch. Niezaprzeczalnie, te ostatnie nadal zajmowały dwa górne szczeble drabiny percepcyjnej. Problematyczne jednak okazało się uznanie jednego zmysłu za dominujący. Spór o prymat wzroku nad słuchem, i odwrotnie, niejednokrotnie przyjmował formę „dialektyki oka i ucha”.

Wraz z przeobrażeniami stylów architektonicznych i trendów artystycznych w obszarze malarstwa i rzeźby, kluczowe przemiany w ramach architektoniki zmysłów przypadły na czasy szekspirowskie. Niemałe znaczenie kompozycyjne miał tu dyskurs filozoficzny, gdzie obowiązywały pewne założenia myśli starożytnej i średniowiecznej, definiowane jako przednowożytne. W odniesieniu do percepcji zmysłowej ścierały się dwa główne podejścia, które można określić jako przedkartezjańskie (przednowożytne) i kartezjańskie (nowożytne). Nie przez przypadek to właśnie Descartesowi przypisuje się doniosłą rolę w ukształtowaniu podwalin pod wielowiekową tradycję pojmowania ludzkiego sensorium. Należy w tym miejscu zaznaczyć, że punktem wyjścia filozoficznych rozważań wspomnianego myśliciela była kwestia relacji pomiędzy ciałem i umysłem. Choć teoretyzowanie na ten temat nie było obce już starożytnym, to jednak dopiero oddziaływanie koncepcji kartezjańskiej uznaje się za przełomowe dla trwałego powiązania koncepcji podmiotowości z problematyką psyche/soma w kulturze Zachodu. Jak podaje David Hillman w pracy Shakespeare's Entrails. Belief, Scepticism and the Interior of the Body: „Szekspir zamieszkiwał świat, w którym szczególnego wysiłku wymagała próba zrozumienia i ponownego przemyślenia związku 
pomiędzy materią i duchem" (2007: 4). Badacz wspomina też o ścierających się wówczas tendencjach ujmowania ludzkiego wnętrza, balansujących pomiędzy prekartezjańską koncepcją ucieleśnionego „ja” i kartezjańską teorią odcieleśnionego podmiotu.

Kartezjusz zaproponował dualistyczny model, zgodnie z którym człowiek jest ukonstytuowany przez dwie substancje: cielesną i racjonalną. Ów paradygmat objął swoim zasięgiem również imperium zmysłów, w tym szczególnie przyczynił się do wyeksponowania podwójnej „natury” percepcji wizualnej. Descartes uściślił dotychczasowe poglądy dotyczące zmysłu wzroku, dokonując rozróżnienia między odseparowanym od ciała „okiem umysłu” i związanym z somą - „okiem ciała”. Wskazując na pokrewieństwo czynności umysłowych i aktywności sfery wizualnej, potwierdził związek sensorycznego postrzegania, który jest rozciągnięty na obszar intelektualnego widzenia „oczyma wyobraźni”" Rację ma Hannah Arendt w Myśleniu (2002), gdy sięgając do fundamentów dyskursu filozoficznego, przypomina, że już w czasach przednowożytnych o czynnościach umysłu „myślano w kategoriach widzenia, a ponieważ myślenie jest najbardziej fundamentalną i najbardziej radykalną czynnością spośród aktywności umysłu, toteż widzenie "stawało się modelem wszelkiej percepcji i miarą innych zmysłów»" (160).

Kartezjusz wykorzystał fakt, że wzrok stanowi podstawę wiedzy o świecie i od wieków uzależnia ludzkie poznanie od widzenia ${ }^{5}$. Warto przywołać tutaj podobne poglądy na zmysł wzroku wśród starożytnych Greków, którzy z jednej strony byli skłonni niemalże wysławiać zdolność widzenia, z drugiej

\footnotetext{
${ }^{4}$ O przenośnym znaczeniu czasownika percepcyjnego „widzieć” pisze Anna Pajdzińska w artykule „Wrażenia zmysłowe jako podstawa metafor językowych” (1996). Autorka zauważa, że poprzez użycie czasowników oznaczających percepcję wzrokową człowiek określa jednocześnie pewne procesy mentalne, spośród których najważniejsze wydaje się zdobywanie wiedzy oraz pojmowanie. Dodatkowo - jak podaje Magdalena Zawiłsławska - autorka monografii poświęconej czasownikom oznaczającym percepcję wzrokową we współczesnej polszczyźnie, wzrok jest aż w 87\% odpowiedzialny za dostarczanie informacji o świecie, przy czym za pośrednictwem słuchu zyskujemy 7\%, węchu - 3,5\%, dotyku - zaledwie 1,5\%, a smaku - jedynie - 1\% informacji (2004: 9).

${ }^{5}$ Poznawanie otoczenia za pomocą zmysłu wzroku wytwarza kolejną, obok wiedzy/władzy, specyficzną relację, której odpowiada zestawienie czasowników widzieć/wiedzieć. Przenikanie „widzenia” i „wiedzy” (charakterystyczny dla języka polskiego jest brak rzeczownika odczasownikowego „wiedzenie”) można dostrzec na przykładzie wspólnego źródła etymologicznego czasowników „widzieć/wiedzieć”. Nie przez przypadek także angielskie słowa „wise”, „wit”, „idea” oraz niemieckie „wissen” etymologicznie czerpią z form czasownika „widzieć". Z kolei związek percepcyjnego postrzegania rozciągnięty na obszar intelektualnego „widzenia oczyma wyobraźni” znajduje wyraz w formach językowych, które umożliwiają poruszanie się po terytorium abstrakcyjnego myślenia. Dzięki takim sformułowaniom, jak: „widzieć rozwiązanie problemu”, „przyglądać się kwestii z jakiegoś punktu widzenia”, „widzieć sprawę pod jakimś kątem", ujawnia się językowa strategia kontroli percepcji wzrokowej nad myśleniem (Kwiatkowska, 1997: 121).
} 
zaś - pozostawali podejrzliwi wobec zwodniczego i iluzjonistycznego potencjału tego zmysłu. Za przykład może posłużyć platońska koncepcja percepcji wzrokowej, pokazująca dwojaki stosunek filozofa do tego zmysłu. W następujący sposób podsumował ją Martin Jay w Downcast Eyes. The Denigration of Vision in Twentieth-Century French Thought (1994):

Ponieważ w jego [Platona] filozofii „wzrok” wydawał się oznaczać jedynie wewnętrzne oko umysłu, faktycznie więc Platon często wyrażał mocne zastrzeżenia co do wiarygodności oczu przy zwykłym postrzeganiu. Patrzymy poprzez oczy, podkreślał, nie zaś samymi oczami ([podkreślenie autora], 27).

Jeszcze większym zwątpieniem w autentyczność przekazu wzrokowego, płynącego od organu cielesnego, wykazał się Kartezjusz. Nie tylko podważył biologiczne znaczenie oczu w procesie dostarczania informacji i budowania wiedzy o świecie, ale także uprawomocnił „rozszczepienie oka” na „oko umysłu” i „oko ciała”. Owo rozdwojenie przekładało się na najbardziej fundamentalną z kwestii w filozofii nowożytnej, czyli problematykę ludzkiej podmiotowości, uwarunkowanej dualizmem substancjonalnym. Dekorporalizacja oka jako narzędzia poznawczego pozwoliła na odłączenie go od ciała i przeciwstawienie mu „somatycznego oka”, którego funkcja ograniczała się do bycia dostarczycielem bodźców wzrokowych z zewnątrz. Próba stworzenia podmiotu opartego na myślącym wnętrzu, rozumianym jako funkcja umysłu, i czującym „zewnętrzu”, pojmowanym jako funkcja ciała, dawała prymat postrzeganiu rozumowemu nad zmysłowym. Można przyjąć, że model podmiotowości wypracowany przez Kartezjusza częściowo odpowiadał na wczesnonowożytne rozterki dotyczące wnętrza/"zewnętrza”, „zamkniętości"/otwartości i duchowości/materialności człowieka.

Przedkartezjańskie stanowisko wobec percepcji wizualnej nie uznawało możliwości odłączenia się myślącego „oka umysłu” od czującego „oka ciała”. Fizyczny wymiar człowieka pokrywał się z jego wymiarem psychicznym w tym sensie, że oba nierozerwalnie ze sobą współpracowały, składając się na ucieleśnione „ja”. Hillman wspomina o „immanencji »ja« w ciele” (2007: 4), czyli somatycznym ujęciu podmiotowości. Badacz twierdzi, że kartezjańska rewolucja zaważyła na powstaniu nowego typu „ja”, na którym ufundowany jest podmiot filozofii nowożytnej (4). Na liminalne pod wieloma względami czasy renesansu przypada więc rywalizacja na polu filozoficznym pomiędzy wspomnianymi orientacjami dotyczącymi ludzkiej podmiotowości. Przemiana, która objęła swym zasięgiem także świat zmysłów, znajduje odzwierciedlenie w sztukach Szekspira, które jednocześnie same zabierały istotny głos w dyskusji na temat statusu zmysłów w kontekście ludzkiej podmiotowości. W opinii Hillmana: 
Szekspir pisał $\mathrm{w}$ decydującym momencie tego przejścia; $\mathrm{w}$ momencie przecięcia się dwóch całkowicie heterogenicznych koncepcji ucieleśnienia - i stąd też modeli podmiotowości. Napięcie pomiędzy tymi modelami wydaje się intensywnie twórcze dla niego i jemu współczesnych. Jednocześnie, wspierając i zwalczając ideę, że „ciężkie ciało"6 jest nieodłączne od myśli, sztuki Szekspira czerpały korzyść z niestabilności w samym sednie koncepcji ucieleśnionego „ja” w tym okresie (5).

Odwołania do percepcji zmysłowej, która niejednokrotnie przynależy do sfery cielesnej, innym razem zaś odpowiada za czynności umysłowe, świadczą o niepewności towarzyszącej ustanowieniu trwałej relacji pomiędzy somą i psyche. Przeplatające się na poziomie tekstualnym, obecne w dziełach Szekspira orientacje przedkartezjańska i kartezjańska mogą sygnalizować, że sztuki dramaturga „mają istotny wkład w historię ucieleśnienia, zarówno jako wskaźniki zmieniających się czasów, jak i elementy prowokujące historyczną i kulturową zmianę" (2007: 3).

W ocenie znaczenia sztuk Szekspira, w tym w szczególności Hamleta, dla rozszczepionej między dwa podejścia filozofii „ja”, Alison Thorne w rozdziale "Hamlet and the Art of Looking Diversely on the Self” sugeruje, że: „Generalnie przyjmuje się, że koniec XVI wieku był przełomowym momentem w kształtowaniu indywidualnego »ja«; momentem, w którym podmiot uzyskał silniejsze poczucie odrębności i władzy nad nadawaniem kształtu i »kreowaniem « własnej tożsamości” (2000: 104). Zdaniem badaczki, Szekspira zaprzątał problem wnętrza/"zewnętrza", znajdujący wyraz w odpowiednio wypracowanej „nowej poetyce języka, odpowiadającej na złożoności życia wewnętrznego" (106). „Wplatanie” w ową poetykę reprezentacji zmysłów wielokrotnie stawia je w świetle niejasnych skojarzeń, co z kolei pozwala na ich dosłowne i metaforyczne interpretacje. Thorne podkreśla doniosłość dramatu Hamlet. Główny bohater traktowany jest w kategoriach symbolicznej postaci, w procesie przemian dotyczących ludzkiej podmiotowości. Na potwierdzenie tego badaczka formułuje tezę, że „[b]ardziej niż jakakolwiek inna literacka kreacja, Szekspirowski, introspektywny książę symbolizuje zwrot ku wewnętrznemu modelowi podmiotowości, z którym łączymy początek czasów nowożytnych" (106).

Inny badacz, Caldwell, analizując wyobrażenia zmysłów w Hamlecie, stawia tezę, że:

Dla renesansowych odbiorców Szekspir, rozwodząc się tak uporczywie nad zmysłami, koncentrował się na sferze wzajemnego kontaktu pomiędzy nieśmiertelną duszą i materialnym światem oraz na miejscu, w którym misternie upleciony węzeł, sprawiający, że jesteśmy ludźmi, jest najmocniej związany. To miejsce, które nie da nam oparcia, tworząc

${ }^{6}$ Chodzi tu o fragment z 44 sonetu Szekspira, który Hillman cytuje w następującej postaci: „dull substance of [the] flesh”, a który został przetłumaczony przez Macieja Słomczyńskiego jako „ciężkie ciało”. 
jakiekolwiek kategoryczne rozróżnienie pomiędzy ciałem i duszą. To miejsce, w którym jedyną właściwą odpowiedzią może być zdziwienie i zakłopotanie (1979: 153).

O aktywnej roli zmysłów Caldwell wspomina przywołując szesnastowieczne poglądy filozoficzne dotyczące interpretacji rzeczywistości. Zadaniem zmysłów miałoby być stanowienie pomostu pomiędzy niematerialną duszą i ciałem. Badacz interpretuje ówczesne podejście do relacji dusza/ciało w kategoriach prekartezjańskich, ponieważ sugeruje, iż, mimo że dusza jest pojmana przez ciało, niemalże $\mathrm{w}$ nim uwięziona, to $\mathrm{w}$ procesie poznawczym element duchowy jest uzależniony od cielesnego, dzięki uczestnictwu zmysłów.

\section{Filozofowanie o zmysłach}

Nieodzowne dla dalszej analizy reprezentacji zmysłów staje się przywołanie wczesnonowożytnych poglądów filozoficznych w tym zakresie. Według Alistair Cameron Crombie, autora pracy Science, Optics and Music in Medieval and Early Modern Thought (1990), przejęte ze starożytnej tradycji dwa stanowiska odnoszące się do funkcjonowania percepcji sensorycznej można sprowadzić do poglądów atomistycznych z jednej strony oraz koncepcji stoickiej - z drugiej. Różnica między nimi polegała na przykład na tym, w jaki sposób aparat postrzegania odbiera informacje z zewnątrz, jaki związek istnieje pomiędzy percypowanym przedmiotem i człowiekiem, oraz w jaki sposób wytwarzane są wrażenia sensoryczne (1990: 177).

Z punktu widzenia szkoły atomistów założenia dotyczące percepcji wizualnej sprowadzały się do tego, że była ona rezultatem oddziaływania „obrazów”, „kopii”, czy też „reprezentacji” przedmiotów. Były one uwalniane w postaci koloru oraz kształtu, i jako swoiste repliki docierały poprzez powietrze do oka. Postrzeganie słuchowe opierało się na mechanizmie oddziałujących na ucho, słyszalnych wrażeń albo cząstek, które odpowiadały wysyłającemu je przedmiotowi i docierały drogą powietrzną do organu słuchu. Teoria ta łączyła bierny odbiór wrażeń wzrokowych i słuchowych, wpadających albo do oka, albo do ucha, a następnie „przechwytywanych” przez duszę, z możliwością dokonania wyboru konkretnego obrazu (przez zwrócenie na niego uwagi) spośród wielu przenikających do narządu wzroku obrazów. Ponadto teoria ta zakładała, że „różniące się, specyficzne zmysły dostarczały odmiennych informacji, ponieważ każdy z nich był przystosowany do tego, by odbierać inny rodzaj zewnętrznego bodźca albo »obrazu«" (1990: 176).

Inne stanowisko reprezentowali stoicy. Utrzymywali oni, że odczucia sensualne są powodowane przedarciem się strumieni cząstek czy też kopii przedmiotów poprzez jakieś medium do odpowiedniego organu. Są one wy- 
nikiem poruszenia lub zmiany wywołanej właśnie w owym transparentnym medium, którego zadaniem było pośredniczenie między przedmiotem i organem percepcji. Jeśli chodzi o widzenie, to miał to być proces, $\mathrm{w}$ ramach którego dusza mogła postrzegać przedmiot, dzięki zewnętrznemu światłu. Stoicy wyróżnili rodzaj pneumy wzrokowej, wysyłanej z mózgu w kierunku oka poprzez nerw optyczny. Przy oddziaływaniu światła pneuma, napierająca na powietrze, miała wchodzić w kontakt z odpowiednim przedmiotem. W przypadku percepcji słuchowej obiekt wydający dźwięk miał powodować falowy ruch powietrza. W rezultacie mógł dotrzeć w postaci wrażeń słuchowych do duszy, dzięki pneumie słuchowej wysyłanej do ucha. Teoria stoików, przejęta i rozwinięta następnie przez Galena (i omówiona w dalszej części pracy), utrzymywała, że rozróżnienie pomiędzy zmysłami „zależało głównie od wewnętrznej reakcji specyficznej pneumy wysyłanej przez duszę do każdego organu zmysłu, co skutkowało nawiązaniem kontaktu z odpowiednim przedmiotem w otoczeniu" (1990: 176). Teoria ta określana jest jako teoria ekstramisjii lub emisji. Teorie opracowane przez atomistów i Arystotelesa noszą wspólną nazwę teorii intromisji (Lindberg 1992: 313).

Skoro zagadnienie podmiotowości i relacji pomiędzy ciałem i umysłem stanowiło jedną z kluczowych kwestii problematycznych w renesansie, warto przytoczyć różne współczesne interpretacje tego wczesnonowożytnego dylematu, z uwzględnieniem teorii medycznych tamtego okresu. Michael C. Schoenfeld w pracy Bodies and Selves in Early Modern England. Physiology and Inwardness in Spenser, Shakespeare, Herbert, and Milton (1999) określił sposoby pojmowania wczesnonowożytnego „ja” na podstawie funkcjonujących wówczas dyskursów z różnych dziedzin nauki. Czołową rolę w kształtowaniu podmiotowości odgrywała - jak podaje autor - teoria fizjologii Galena (obok klasycznej etyki oraz protestanckiej teologii) (1999: 11). Galen połączył wiedzę lekarską z przemyśleniami filozoficznymi. Za punkt wyjścia w badaniach nad organizmem ludzkim obrał koncepcję duszy, inspirowaną koncepcją Platona i przede wszystkim ideą pneumy, zaczerpniętą od stoików. Od Platona przejął podział duszy na trzy części, które rządzą i służą ciału, i mają swe ośrodki somatyczne. Każda część duszy objawia się pewną zdolnością wybranego organu ciała. Mózg posiada zdolność psychiczną, przez co odpowiada za myślenie, odbieranie i przetwarzanie wrażeń oraz świadomy ruch. W sercu znajduje się ośrodek o zdolności witalnych, odpowiedzialny za emocje, zaś wątroba odpowiada za odżywianie i metabolizm. Innymi słowy, dusza racjonalna, dusza zwierzęca i dusza wegetatywna rezydowały odpowiednio w mózgu, sercu i wątrobie (Wilson, 2006: 45).

Jak podaje R. H. A. King w pracy Common to Body and Soul: Philosophical Approaches to Explaining Living Behaviour, z teorii Galena wynika, że „[w] szystkie części duszy, [...], znajdują się wyraźnie (podczas spełniania swoich funkcji i wykazywania się odpowiednimi zdolnościami) pod wpły- 
wem kondycji ciała - i odnosi się to tak samo do naszych zdolności myślenia, jak do emocji oraz pragnień" (2005: 249). Jego doktryna kładzie zatem nacisk na wzajemne oddziaływanie ciała i duszy, implikując psychosomatyczną integrację jednostki. By pokazać, jak przebiega mechanizm tego oddziaływania, Galen posłużył się terminem „pneuma”, zaczerpniętym od poprzedników. Przyjmując rozbudowaną teorię pneumy, zaaprobował rozróżnienie na pneumę niższego rzędu - zwaną witalną - i pneumę wyższego rzędu, czyli psychiczną. Według Galena powietrze, które przenika do organizmu i dostaje się do krwi, następnie przemienia się $\mathrm{w}$ „subtelniejszy produkt” (Wilson, 2006: 45), czyli właśnie w pneumę.

Przedstawiając w uproszczeniu skomplikowany proces wędrówki tej substancji, opracowany przez Galena, należy przyjąć, że pneuma witalna dostaje się do mózgu, gdzie ulega transformacji w pneumę psychiczną. Stąd z kolei przedostaje się „niedostrzegalnymi kanałami”, obecnymi w nerwach sensorycznych i motorycznych, by ostatecznie spowodować odczucia sensoryczne i wywołać świadomy ruch mięśni (2006: 45). Zatem w teorii zmysłów Galena głównym ośrodkiem percepcji jest mózg. Jeśli chodzi o percepcję wzrokową, to odrzucił on teorię, jakoby

widzenie było skutkiem tego, że obraz przedostaje się do narządu wzroku. Teoria ta nie wyjaśniała ani postrzegania przez jedną osobę dużych obiektów, takich jak góry, których obraz nie zmieściłby się w źrenicy, ani postrzegania jednego obiektu przez wiele osób, z których każda miałaby odebrać jego obraz (Crombie, 1990: 184).

Galen był zwolennikiem twierdzenia, że pneuma optyczna, produkowana w mózgu, dociera do oka i styka się z nim dzięki nerwowi optycznemu, by później podążyć w stronę obiektu i dosięgnąć go, niejako „dotknąć”. Następnie odmieniona pneuma powraca do oka, a stąd już trafia do mózgu przez nerw optyczny (Debru, 1995: 39).

Powszechnie znana i akceptowana teoria humoralna Galena traktowała ciało jako dający się przeniknąć, porowaty i nieodgrodzony od świata zewnętrznego element ucieleśnienia. Taka konceptualizacja somy przyzwalała na nieskrępowany przepływ informacji między wnętrzem i „zewnętrzem” oraz na swobodne oddziaływanie jednego ciała na drugie. Ciała były względem siebie „otwarte”, zaś postrzeganie zmysłowe ściśle związane było z somatycznym wymiarem człowieka. Porównując przedstawione wyżej podejście do zmysłów z rodzącą się koncepcją rozdzielającą psyche i soma, Hillman twierdzi, że

dawne fizjologiczne rozumienie sensorycznej aktywności (takiej jak widzenie i słyszenie), biorące za podstawę coś (promienie oka, wiązki światła, fale), co wchodzi do i wychodzi z wnętrza ciała, zmieniało się po to, by dopasować się do znacznie mniej przenikalnego modelu, zgodnie z którym ciało naturalnie funkcjonuje (2007: 8). 
Tym drugim modelem miało być ujęcie procesu widzenia zgodnie z funkcjonowaniem przyrządu zwanego camera obscura. Punktem wyjścia do analizy fizjologii widzenia był sam organ wzroku. Zanim doszło do przełomowych odkryć w postaci nowych narzędzi „przedłużających” lub ulepszających widzenie, to właśnie samo oko stanowiło najbardziej złożony system optyczny podlegający badaniom.

Jak podaje Johns, typowe dla okresu renesansu były przedstawienia oka jako camera obscura, której działanie przyrównywano do funkcjonowania organu wzrokowego. Badacz opisuje to zjawisko następująco:

Camera obscura składała się z ciemnej komory dowolnych rozmiarów - od małego pudełka po pokój wystarczająco duży, by zmieścić w nim człowieka - posiadającej otwór w jednej ze ścian. Światło wpuszczone przez ten otwór formowało odwrócony obraz zewnętrznego otoczenia na przeciwległej powierzchni. Sądzono, że wewnątrz oka, w adekwatny sposób, obraz miał być „wyryty” albo „namalowany” (używano obu słów) na siatkówce (1998: 389).

W osadzeniu się obrazu na powierzchni siatkówki pośredniczyły „dusze” (389), przesyłające go z nerwów optycznych do mózgu. Następnie obraz ponownie był „wyryty” (389) na czymś o nazwie sensus communis i ostatecznie postrzegany przez umysł. Owo sensus communis „,było wytłaczane w tej samej chwili co siatkówka i w taki sposób, że pośredniczylo w tym procesie ludzkie ciało” (389). Co ciekawe - wrażenia „padające na” sensus communis nie pochodziły tylko od zmysłu wzroku, ale każdy inny zmysł mógł je zainicjować. Ponadto wrażenia niekoniecznie musiały pochodzić spoza ciała. Jako przyczynę Johns podaje proces zapisywania, identyczny dla obrazów wytwarzanych przez wyobraźnię, jak i dla tych inspirowanych percepcją skierowaną na zewnątrz ciała (389).

Bez względu na to, czy umysł postrzegał obraz wewnętrznie, za pomocą wyobraźni, czy zewnętrznie, za pomocą istniejącego obiektu, to obraz ten był i tak zapisywany na powierzchni sensus communis, zaś umysł nie odróżniał natury jego pochodzenia. Johns przytacza pogląd Kartezjusza, który uważał, że pojęcie „idea” należało stosować w obu przypadkach: tak samo w stosunku do wrażeń wywołanych wyobraźnią, jak i wobec kontaktu percepcyjnego z obiektem zewnętrznym. Dalej autor wyjaśnia, że „idee działały jak bodziec do fizycznej aktywności. Impulsy powodujące takie działanie były przekazywane przez całe ciało przez ten sam system nerwowy, który pośredniczył w percepcji” (1998: 391). Konsekwencją takiego rozumienia pracy percepcji wzrokowej, wchodzącej w interakcję z ciałem i wyobraźnią, było uznanie, że wiedza oparta na wizualnym postrzeganiu ma dwojaką, a przez to niedookreśloną naturę.

Wraz z rodzącą się ideą ciała niedostępnego i zamkniętego zmysły miały znaczącą rolę do odegrania jako organy pośredniczące między psychiką i cielesnością. Oko i ucho były uznawane ówcześnie za psychofizyczne narządy, 
których funkcjonowanie nie powodowało wyobcowania „ja” z ciała. Zdaniem Jennifer Rae McDermott, autorki „Perceiving Shakespeare: A Study of Sight, Sound, and Stage”, „psychofizjologia pozwala na płynne wzajemne przenikanie się ciała, umysłu i uczucia, bez podziału na umysłową koncentrację (baczenie) i funkcję fizyczną". Badaczka odczytuje zmysły, zwracając uwagę na rolę wzroku i słuchu w kontekście wczesnonowożytnej ucieleśnionej psychiki. Powołuje się na ówczesną koncepcję, według której pojęcie psychiki objęło sferę zmysłów. Dzięki temu, poprzez czujność i baczenie, aktywnie uczestniczyły w procesie postrzegania. McDermott uważa, że:

Narządy wzroku i słuchu otrzymywały bodźce, zachęcające je do „otwartości” albo „uważności”. Obdarzając je możliwością działania wierzono, że fizyczny organ [oko i ucho] dokonuje wnikliwego osądu: uważny instrument zmysłowy odfiltrowywał dobro od zła. Aby zmysł był uważny, powinien posiadać zdolność nie tylko odbierania bodźców, ale również postrzegania jego pełnego znaczenia - aktywnego widzenia, a nie tylko patrzenia, oraz aktywnego słuchania aniżeli jedynie słyszenia („Perceiving Shakespeare”).

Przedkartezjańskia psychofizjologia nie pozwalała ludziom ery wczesnonowożytnej na odseparowanie umysłu od porowatego i wypełnionego płynami humoralnymi ciała. Takie pojmowanie jednostki uniemożliwiało także wyizolowanie ciała ze świata zewnętrznego, który miał w istotny sposób wpływać na zmiany zachodzące w/na ciele. Konsekwencją psychofizjologicznego pojmowania „ja” było umiejscowienie postrzegania zmysłami pośród kluczowych doświadczeń w procesie samodoświadczania.

Myśl przedkartezjańską charakteryzowała tendencja do faworyzowania modelu otwartości pomiędzy tym, co materialne, a tym, co duchowe. Wczesnonowożytne pojmowanie zmysłów przeciwstawiało się dualistycznym kategoriom kartezjańskim, wśród których można wyodrębnić między innymi: wnętrze/„zewnętrze”, pasywność/aktywność, literalność/figuratywność oraz materialność/duchowość. Szekspir w swoich dramatach nie tylko porusza skomplikowane relacje między tymi pojęciami, nie tylko balansuje pomiędzy odcieleśnioną/ucieleśnioną percepcją, ale również pokazuje, jak koncepcja przedkartezjańska, choć nadal silnie oddziałująca na wyobraźnię renesansową, stopniowo traciła swą aktualność na rzecz nowych trendów myślowych epoki. Rodzący się kartezjanizm ścierał się z przedkartezjanizmem, modyfikując rolę zmysłów i sprawiając, że postrzeganie zmysłowe zyskało status liminalności.

Teoria fizjologii Galena miała niemały wpływ na wytworzenie „reżimu samokontroli” (Schoenfeldt, 1999: 11). Powstał on poprzez „samokontrolę uprawniającą jednostki" (11), które nie były jedynie ofiarami władzy o społecznym zasięgu, lecz posiadały uprawnienia do autokreacji, wynikające z wymienionych powyżej dyskursów. Schoenfeld podkreśla „wyzwalający” i kreatywny aspekt autokreacji jako jeden z efektów dyscyplinujących dys- 
kursów. Badacz akcentuje materialny wymiar jednostki w sensie cielesnym, pisząc o porowatości, przenikalności i podatności ciała, której mieli być świadomi ludzie ery wczesnej nowożytności, między innymi dzięki znajomości teorii humoralnej Galena. Zindywidualizowanie jednostki odbywało się zatem w aktach autokreacji, przy czym fizyczny aspekt odgrywał tutaj kluczową rolę. Poczucie autonomii oraz własnej siły i ważności wywoływało poczucie kontroli nad emocjami i humorami (11-12).

Schoenfeld zauważa, że Szekspir często posługuje się terminologią fizjologiczną, co prawdopodobnie odzwierciedla ówcześnie wykluwające się koncepcje opisujące wnętrze jako element podmiotowości. W ocenie tego autora „[b]yć może znamienne jest to, że Hamlet - Szekspirowska sztuka, która jest najczęściej przytaczana $\mathrm{w}$ argumentacji, poszukując momentu, by zainaugurować »nowożytną podmiotowość«, sama jest przesiąknięta tą terminologią" (1999: 75). Niewidoczne dla oczu wnętrze staje się ważnym elementem kultury percepcyjnej, zawieszonej między wczesną wizualnością a późną akustycznością. Kształtująca się wczesnonowożytna koncepcja tożsamości przywiązywała dużą wagę do cielesnych przejawów wnętrza i zachowań korporalnych. Panowanie nad nimi stanowiło element samopostrzegania, ale także postrzegania ,ja” przez innych.

\section{Kreacja wczesnonowożytnego „ja”}

Na wyłaniające się wczesnonowożytne „ja” przemożny wpływ miały przemiany dotyczące powstawania nowych kulturowych form postrzegania siebie przez człowieka. Jedną z takich form, zrodzonych dzięki postępującej świadomości indywidualizmu jednostki oraz z potrzeby jego zaakcentowania, była literacka forma autobiografii, pamiętnika i opowieści tworzonych z pozycji pierwszej osoby. Peter Burke w artykule „The Self from Petrarch to Descartes" wspomina, że autobiografia nazywana jest czasami „ego-dokumentem" (1997: 21). Są to zapisy spostrzeżeń na temat samego siebie, przepełnione relacjami „z pierwszej ręki”. Tego typu praktyki „znacząco zwiększały osobistą zdolność do tego, by stać się bardziej zaabsorbowanym sobą i bardziej świadomym siebie, czyli, by stać się indywidualnością" (Smith, 1997: 55). Postrzeganie zmysłowe zostaje zatem skierowane w głąb siebie $\mathrm{w}$ procesie autopercepcji. Obserwacja i wsłuchiwanie się w samego siebie, w swój dialog wewnętrzny znalazły wyraz w postaci monologów w sztukach jako „prywatnej' formy literackiej” (Thorne, 2000: 105). W przeciwieństwie do czasów średniowiecznych, kiedy to - zgodnie z przywołaną w artykule „The Self from Petrarch to Descartes” teorią Jacoba Burckhardta - ludzie byli świadomi siebie jedynie na podstawie przynależności do grupy, w okresie renesansu wzrosło zainteresowanie wewnętrznym życiem jednostki do ta- 
kiego stopnia, że można mówić o człowieku jako „uduchowionej jednostce”, postrzegającej siebie właśnie w ten sposób (Burke, 1997: 17).

Inny przejaw kreowania renesansowego „ja” oraz formowania wiedzy w wyniku autopercepcji stanowiła malarska konwencja tworzenia autoportretów. Będąc istotnym elementem rodzącej się kultury wczesnowizualnej, autoportret jest także przywoływany, by pokazać wyłaniający się w tamtym okresie kult osobowości (Thorne, 2000: 105). Utrwalanie podobizn na płótnach mogło świadczyć o potrzebie ekspresji postrzegania człowieka przez samego siebie w kategoriach zindywidualizowanej postaci, która pragnie, by uwaga skupiała się tylko na niej. Wnętrze wyrażone poprzez sportretowanie „zewnętrza” było sposobem na przekazanie doświadczenia towarzyszącego aktom postrzegania. Poprzez analizę ucieleśnionego ,ja” twórca portretu przekraczał granice pomiędzy tym, co ukryte w środku, a tym, co wyrażane na zewnątrz. Samoobserwacja, służąca zarówno wejrzeniu w stany zachodzące wewnątrz, jak i poza nim, jawi się jako kluczowy bodziec do stworzenia autoportretu. Wizualny wymiar introspekcji dotyczy więc wglądu w sferę umysłową, zaś studium własnego wyglądu odnosi się już tylko do powłoki somatycznej. Jednak oba zabiegi wymagają autopercepcji, która w okresie wczesnej nowożytności zaczyna nabierać nowego znaczenia poznawczego. Chodzi tu o autorefleksyjne poznanie siebie z tendencją do coraz wyraźniejszego rozgraniczania na to, co wewnętrzne i zewnętrzne. Jak podaje Hillman, „jednym z głównych wyzwań szesnasto- i siedemnastowiecznej Anglii była [właśnie] renegocjacja granic wnętrze/»zewnętrze«" (2007: 7).

Niemałą rolę w procesie autorefleksji odgrywały - zdobywające w XVI wieku coraz większą popularność - lustra, które uznawano za źródła wiedzy o samym sobie. Produkcja płaskich luster na dużą skalę przyczyniła się do ich powszechnej obecności. Zanim pojawiły się owe lustra, dominowały zwierciadła ze szkła dmuchanego, które powiększały obiekty znajdujące się w ich bliskości, co niekoniecznie sprzyjało oglądaniu siebie w całości. Dopiero lustra okresu renesansu ułatwiły przeglądanie się dzięki możliwości odbicia całej postaci (Smith, 1997: 53). Lustra umożliwiały skupienie uwagi i zwrócenie oczu ku sobie. Był to jedyny sposób, by przyjrzeć się sobie w dosłownym znaczeniu. Lustrzana kontemplacja budowała silniejsze niż dotychczas poczucie odrębności i możliwości wypracowania wiedzy na swój temat. Thorne utrzymuje, że „lustro staje się pośrednikiem w nieprzerwanym badaniu tożsamości" (2000: 126). Zwierciadlane odbicie służy jako mniej lub bardziej wiarygodne źródło prawdy o sobie. Percepcyjne doświadczanie siebie za pomocą odbijającej powierzchni lustra było niemalże zabiegiem filozoficzno-medycznym przy użyciu spekulatywno-optycznego narzędzia.

Zgłębianiu samego siebie towarzyszyła również nie mniej intensywna chęć przeniknięcia do tego, co ukryte w innych. Obok autoportretu coraz popularniejsze w tamtym okresie było malowanie portretów. Renesansowe 
uwiecznienie jednostki na płótnie różniło się od wcześniejszych przedstawień na obrazach. Przełomowy moment w historii malarstwa stanowiło renesansowe odkrycie perspektywy linearnej. Zdaniem Jaya: „Znaczenie tego wynalazku było takie, że średniowieczne założenie wielości punktów obserwacyjnych, z których można było namalować otoczenie (co także czasami oznaczało całkowity brak faktycznego punktu obserwacyjnego), zostało zastąpione jednym niezależnym sposobem widzenia" (1994: 54). W rezultacie w miejsce dotychczasowego rozproszenia punktów widzenia pojawiło się uprzywilejowane spojrzenie obserwatora o cechach badawczych, kontrolujących i opiniotwórczych. Średniowieczne malarskie reprezentacje, na których postacie są płaskie i mało zindywidualizowane, zostają wyparte przez silnie zaakcentowaną głębię renesansowych sylwetek. Sztucznie narzucona hierarchia elementów na obrazach średniowiecznych powoli znika, by ustąpić miejsca bardziej naturalnej kompozycji, osiągniętej poprzez zastosowanie perspektywy linearnej.

Perspektywiczność miała swoje przełożenie na sposób postrzegania materialnej rzeczywistości. Tendencja do zajmowania uprzywilejowanej pozycji obserwatora spowodowała, że tak samo malarz, jak i później osoba oglądająca dzieło, dystansowały się albo wręcz izolowały się od niego. W ocenie Stuarta Clarka, autora książki Vanities of the Eye. Vision in Early Modern European Culture (2007):

Świat wizualny został uprzedmiotowiony, zarówno w takim sensie, że stał się czymś obserwowanym spoza płaszczyzny obrazu, „wyobrażany jako przypominający okno, transparentny "punkt przecięcia «, stojący pomiędzy artystą a scenerią, którą ma przedstawić", jak i w takim sensie, że ta obserwacja koncentrowała się na pojedynczym, suwerennym, lecz odcieleśnionym, niezmiennym i statycznym sposobie widzenia (85).

Podobne spostrzeżenie poczynił Jay, utrzymując, że doszło do odseparowania oglądającego i oglądanego, oraz unieruchomienia punktu widzenia (1994: 55). Nowy porządek malarski zainaugurował odmienny sposób ujmowania świata percypowanego, zarówno w teorii, jak i w praktyce.

Obiektywizujące i odcieleśnione spojrzenie perspektywiczne, które „pozbawiało” oko jego somatyczności, korespondowało z kartezjańskim dualizmem substancji. Z pism tego filozofa wyłania się renesansowe myślące „ja”, które odpowiada zindywidualizowanej perspektywie oglądającego (namalowany obraz albo świat jako rzeczywistość). W artykule „Self-Reflection and the Self” Roger Smith zauważa, że w jego pracach uwypuklono ,ja” jako podmiot wykonujący określoną czynność: „Chodzi o to, że [Kartezjusz] wybrał »ja « na bohatera opowieści" (1997: 51). Filozof opisuje doświadczenia percepcyjne z pozycji własnej istności. Badacz wyjaśnia dalej, że personalny sposób użycia pierwszej osoby liczby pojedynczej przez Kartezjusza różni się od scholastycznego zastosowania tego zaimka osobowego w sensie bezosobowego podmiotu. Smith podkreśla, że: 
Znaczące jest to, że kiedy Kartezjusz zwraca się ku wnętrzu, by zbadać własny umysł jak źródło wiedzy, przedstawia to jako indywidualny akt, nie zaś akt charakterystyczny dla doświadczenia życiowego w określonej społeczności ludzi. Kładł on nacisk na samopoznanie jako indywidualne, przeciwne społecznemu dokonanie (51).

Rozwijająca się w czasach wczesnej nowożytności teoria na temat zmysłów równocześnie akcentowała zarówno późnoakustyczne, jak i wczesnowizualne idee, wartości, symbole i praktyki społeczne. Ewoluując w kierunku wzrokocentryzmu, kultura zachodnia zaczerpnęła z okresu renesansu istotne podstawy ideologiczne i fundamentalne wynalazki. Te ostatnie w szczególny sposób były powiązane ze zmysłem wzroku. Innowacje przyjmowały postać, albo „przedłużenia” ludzkiej zdolności percepcyjnej (na przykład mikroskop i teleskop), albo usprawnienia technologii rozpowszechniania informacji i dotychczasowej wiedzy za pomocą środków wizualnych, przy czym najważniejszą rolę odegrał w tym procesie druk (Jay, 1997: 65). Zintensyfikowane pojawienie się różnorodnych technicznych udoskonaleń percepcji wzrokowej oraz form rozprzestrzeniania wiedzy, bazujących na wzroku, spowodowało, że w dziedzinie wynalazków narząd wzroku zdominował pozostałe organy zmysłowe.

$\mathrm{Z}$ pewnością również badania medyczne i teorie filozoficzne na temat funkcjonowania i znaczenia wzroku przyczyniły się do poszerzonej znajomości tego zmysłu w porównaniu z innymi. Niesłabnące zainteresowanie mechanizmem widzenia oraz znaczeniem kulturowym postrzegania wzrokowego jako narzędzia dyscyplinującego, obiektywizującego i poznawczego, wpłynęło na wyjątkowe rozbudowanie metaforycznego słownictwa wizualnego $^{7}$ oraz lingwistyczną obfitość nazewnictwa odsyłającego do organu wzrokowego ${ }^{8}$. Ciekawą uwagę poczyniła Arendt, oznajmiając że „[d]ominacja

\footnotetext{
${ }^{7}$ Znaczenie percepcji wzrokowej komunikuje bogate słownictwo z zakresu wzrokowości, na przykład ociemnieć/zaniewidzieć znaczy pogrążyć się w ciemnościach, zaś odzyskać wzrok to ponownie ujrzeć światło. Można dosłownie przestać widzieć światło, czyli fizycznie utracić zdolność reakcji na światło, kiedy mechanizm przetwarzania zmysłowego zawiedzie. O osobie ociemniałej można jednocześnie powiedzieć, że pogrążyła się w ciemnościach, ale również to, że jej umysł może być światły (połączenie znaczenia literalnego z figuratywnym). Widzieć światło/jasność lub mrok/ciemność stanowią fundamentalne skojarzenia, przywołujące na myśl zarówno fizyczną sprawność narządu wzroku, odbierającego bodźce świetlne (lub nieczułego na nie), jak i stan umysłu, czy to światłego/oświeconego, czy też zatraconego w otchłani niewiedzy/nieprawdy. Metaforyczny sposób przekazania wiedzy o intensywności widzenia przenosi znaczenia na grunt symboli, oznaczających stany orientacji/dezorientacji, odnalezienia/zagubienia oraz wiedzy/niewiedzy.

${ }^{8}$ Dla uchwycenia realiów okulocentrycznych godna przedstawienia wydaje się lingwistyczna analiza kluczowego czasownika „widzieć”. Widzieć to posługiwać się organem wzroku, czyli zdobywać wiedzę o otaczającym świecie. Powołuję się tu na dosłowną właściwość tego leksemu, według klasyfikacji zawartej w Słowniku Języka Polskiego pod red. Witolda Doroszewskiego, zaś pozostałe pięć znaczeń ma wymiar metaforyczny. Będą to: (1) „możliwość spotkania się, zetknięcia z kimś”, (2) „odtwarzanie, wywoływanie w pamięci, w wyobraźni; wyobrażanie sobie czegoś”, (3) „stwierdzanie czegoś, przekonywanie się o czymś, dochodze-
} 
wzroku jest tak głęboko zakorzeniona w języku Greków, a także w naszym pojęciowym języku, że rzadko ktoś się nad tym zastanawia, gdyż jest to rzecz zbyt oczywista, by mogła być zauważona" (2000: 160).

W artykule „Z perspektywy Martina Jaya, czyli o tym jak »przymknąć» oko", Jarosław Przeźmiński przywołuje trzy koncepcje istotne dla rozwoju nowożytnego okulocentryzmu:

\begin{abstract}
A mianowicie radykalne rozdzielenie res extensa od res cogitans, a co za tym idzie, aparatu poznawczego od ciała. Od tego momentu percepcja wrażeń, w tym szczególnie wrażeń wzrokowych, wyobrażana będzie w postaci lustra, w którym odbija się świat zewnętrzny, a na które spogląda „oko umysłu” [...]. Idea boskiej perspektywy i teza o mathesis universalis przyczyniłysiędorozwoju deterministycznego mechanicyzmu wbadaniach prawprzyrody, ale i historii, kultury itp. Dominację kartezjańskiego perspektywizmu, a więc przekonania o istnieniu jakiejś wyższej niż ludzka perspektywy, w której partycypacja przynieść może jedynie płodne poznawczo efekty, mechanicystyczną koncepcję aparatu poznawczego jako camera obscura oraz współwystępujące z tymi zjawisko upowszechnienia się perspektywy w malarstwie M. Jay uznaje za filary nowożytnego wzrokocentryzmu, który jako dominująca ideologia przetrwał aż do schyłku XIX w. (1998: 339).
\end{abstract}

Kolejnym elementem omawianej przeze mnie teorii jest związek pomiędzy danym zmysłem i przypisywanymi mu wartościami genderowymi. W pracy The Color of Angels Constance Classen bada, w jaki sposób „zmysły są modulowane przez genderowe wartości" (1998: 63). Badaczka wyróżnia znaczenia przypisywane kulturowym konstrukcjom zmysłów oraz płci społeczno-kulturowej, a następnie docieka, jak te znaczenia wytwarzają specyficzne związki między danym zmysłem a męskością albo kobiecością (na przykład „męskie spojrzenie” albo „kobiecy dotyk”). Według Classen kultura zachodnia wypracowała model percepcyjny, w którym kobiety powiązano, albo po prostu ze zmysłami, albo z tymi uznawanymi za „niższe”: „Kobiety to zakazany smak, tajemniczy zapach i niebezpieczny dotyk" (2). Z kolei mężczyźni byli kojarzeni z intelektem, jako kontrastem dla zmysłów, lub łączono ich ze zmysłami stojącymi najwyżej w hierarchii, czyli ze wzrokiem i słuchem. Zdaniem badaczki: „Przesłonięcie sensorycznych podwalin kultury Zachodu przez nowożytny, wizualny i racjonalny światopogląd można zatem odczytać jako przesłonięcie określonych kobiecych wymiarów tej kultury innymi wymiarami" (2). To stwierdzenie odkrywa istotny aspekt wczesnonowożytnej kultury percepcyjnej, mianowicie jej kluczową rolę w ustanowieniu zależności między danym zmysłem a waloryzowaniem go jako męski bądź

nie do wniosku, zdawanie sobie sprawy z czegoś, uświadamianie sobie czegoś”, (4) „upatrywanie kogoś/czegoś w kimś, uważanie za kogoś” oraz (5) „zwracanie uwagi na kogoś, na coś, zauważanie” (Zawisławska, 2004: 9). 0 ile dosłowne znaczenie czasownika „widzieć” posiada funkcję czysto zmysłową, pozwalającą na orientację przestrzenną, jakby niezależną od widzącego, o tyle metaforyczne użycie tego czasownika sugeruje, że widzieć to celowo wchodzić w kontakt, interpretować, rozumieć, rozpoznawać i pojmować. 
kobiecy. Znaczenia nadane percepcji słuchowej lub wzrokowej, łączonych z rozumowością, prawdą i obiektywną wiedzą, przyczyniły się do przesunięcia na pozycje marginalne zmysłów kobiecych: dotyku, smaku i węchu.

Biorąc pod uwagę kulturowe praktyki wykorzystywania zmysłu wzroku i słuchu przez każdą z płci, także na tym polu spotykamy wyraźnie asymetryczne podziały. W opinii Classen istniały „szlachetniejsze jakości danego zmysłu", które kulturowo przypisywano mężczyznom, zaś kobiety kojarzono „z mniej chlubnymi jakościami” (1998: 66). Badaczka twierdzi, że, na przykład, szlachetniejszą jakością postrzegania wzrokowego były czynności intelektualne (mogło być to czytanie), a dla przeciwwagi „kobiety miały robić z niego użytek dla wrażeniowych celów przy nabywaniu krzykliwych strojów i dla podziwiania się w lustrze" (66). Analogicznie miał być wykorzystywany słuch, czyli kobietom służył przede wszystkim do mało wyszukanych czynności plotkowania lub prowadzenia rozmów o miłości, zaś dla mężczyzn stanowił instrument do prowadzenia ważnych dyskusji (66). Podział zmysłów ze względu na płeć w istotny sposób dopełnienia założenia wczesnonowożytnej teorii postrzegania, której poszczególne elementy, celowo zaprezentowane $\mathrm{w}$ tym rozdziale, znajdują swoje miejsce $\mathrm{w}$ analizowanym $\mathrm{w}$ dalszej części książki dramacie Hamlet. 
Rozdział 4

\section{Dramat Hamlet dramatem zmysłów}

\section{Jak rozszyfrować „,kod sensoryczny" dramatu?}

Każde doświadczenie sensualne, oprócz wymiaru biologicznego, posiada również wymowę kulturową. Mogłoby się wydawać, że pierwsze znaczenie przynależy wyłącznie do sfery subiektywnego odbioru bodźców pochodzących od zmysłów, jednak okazuje się, że pozostaje ono niesamodzielne, gdyż druga postać modyfikuje owo przeżywanie. Kulturowa konstrukcja zmysłów przyczynia się nie tylko do określonego stylu postrzegania otoczenia materialnego, ale także do oddziaływania i reakcji na innych ludzi. W twórczości Szekspira można odnaleźć serię przykładów utrwalania ulotnych doświadczeń zmysłowych jego epoki. Szekspirowskie literackie reprezentacje zmysłów odzwierciedlają podejście do zmysłów w okresie wczesnej nowożytności ${ }^{1}$. Interpretacja znaczeń i „zmysłowych preferencji”, wyłaniających się z tychże poetyckich obrazów oraz opisów, wskazuje na szczególną niestabilność kultury percepcyjnej czasów renesansowych. Kultura ta, przechodząca istotne zmiany pod wpływem wielu dziedzin naukowych i pozanaukowych, odznaczała się nasileniem wartości i ideologii, które nie pozostały bez wpływu na świat zmysłów.

O różnicach w podejściu do zmysłów w czasach elżbietańskich wspomina Caldwell, sugerując, że traktowano je wówczas jako „aktywnych tłumaczy rzeczywistości” (1979: 144), nie zaś jako „przezroczyste okulary, niemające wpływu na interpretowanie danych z otoczenia" (144). Liczne pisma naukowe z tamtego okresu wskazują na spory między zwolennikami podejścia, że zmysły jedynie pośredniczą w przekazywaniu informacji do umysłu oraz rzecznikami tezy, iż dość znacząco kształtują one i interpretują otaczający świat. Często komentowana kwestia eksplikacji rzeczywistości i roli zmysłów w tym procesie - zdaniem Caldwella - znajduje odzwierciedlenie w Hamlecie; odzwierciedlenie rozpoznawane przez część czytelników i uczestników przedstawień teatralnych w czasach Szekspira (144).

${ }^{1}$ Zdaniem Classen, prace z zakresu literatury zdradzają, jaka była klasowa hierarchia wartości sensorycznych w okresie życia danego autora (Classen, 2001: 357). 
W opinii McDermott reprezentacje zmysłów, które funkcjonowały we wszesnonowożytnych dyskursach, przedstawiały je często w formie samych organów zmysłów. Te zaś z kolei jawiły się jako podmioty, a nie przedmioty, na dodatek aktywnie działające. Uważano, że oko czy ucho były nie tylko pasywnie odbierającymi bodźce częściami ciała, ale podmiotami o określonych właściwościach - oceniającymi, filtrującymi, pożądającymi, a przede wszystkim wykazującymi aktywą uwagę. Popularne metafory z tego okresu przyrównują zmysły do szpiegów. W obiegu funkcjonowały takie określenia na zmysły, jak donosiciele/informatorzy czy wywiadowcy, działający pomiędzy ciałem a duszą („Perceiving Shakespeare”). McDermott przytacza szesnasto- i siedemnastowieczne poglądy na organy percepcji wzrokowej i słuchowej, pisząc, że

oczy i uszy zajmują pierwszoplanową pozycję ponad innymi organami zmysłowymi, ponieważ nie opierają się na fizycznej styczności. [Organy te traktowane są] jako aktywni pośrednicy pomiędzy wewnętrzną zdolnością pojmowania a światem zewnętrznym. Swobodnie wałęsają się [po świecie zewnętrznym] i powracają z odpowiedziami do będącej u władzy duszy. Doręczając informacje o własnościach świata zewnętrznego „do" ciała, zmysły przy-„,noszą” zdobywanej wiedzy materialną formę jako dosłowni „do-nosiciele” („Perceiving Shakespeare”).

0 roli zmysłów jako „do-nosicieli”, czyli aktywnych podmiotów w procesie poznania, świadczy uznanie ich za niezależnych i uważnych interpretatorów rzeczywistości, mających znaczący wpływ na dostęp do prawdy. Jak pokaże dalsza analiza reprezentacji zmysłów w Hamlecie, Szekspir zobrazował je zgodnie z renesansową teorią zmysłów, co podkreśla fakt niemalże obsesyjnego poszukiwania przez różnych bohaterów - za pomocą zmysłów - wiedzy prawdziwej i skutecznie ukazującej prawdę o innych i o świecie, w jakim toczy się akcja dramatu.

Caldwell sugeruje nawet, że niezbadanym terytorium tragedii pozostaje świat postrzegania zmysłami, a także, że „obrazowanie zmysłu” (1979: 137) wymaga dogłębnej analizy, gdyż: „Obserwowanie i słuchanie, szpiegowanie i podsłuchiwanie mają przemożne znaczenie w tej sztuce. Położony jest też aluzyjny i celowy nacisk na pięć zmysłów, ich właściwe funkcje oraz fizyczną i duchową chorobę, która je prześladuje" (137). W opinii badacza obrazowanie zmysłów składa się na istotny schemat, według którego rozwija się akcja dramatu. Ów schemat uobecnia się w języku, wpływa na nasze odczytanie bohaterów i przenika do wystawień teatralnych i sposobu ich wyreżyserowania (137). Można w tym miejscu zaznaczyć, że pionierską pracą w zakresie obrazowania w dziełach Szekspira była Shakespeare's Imagery and What It Tells Us (1935) autorstwa Caroline Spurgeon. Badaczka zajmuje się w niej treścią poszczególnych obrazów i podkreśla powiązanie między poetyckimi obrazami i odzwierciedlaniem przez nie osobowości Szekspira. Zgodnie z tą teorią, wyobrażenia w sztukach mają dokumentować sposób, w jaki autor po- 
strzega rzeczywistość. Z kolei nieco innym aspektem obrazowania u Szekspira zajął się praktycznie w tym samym czasie Wolganag Clemen. W The Development of Shakespeare's Imagery (1936) zaznacza on, że istotna jest nie tyle sama treść obrazu, co kontekst, w jakim obrazowanie pojawia się w danym momencie w sztuce. Badacz przestrzega też przed izolowaniem poszczególnych wyobrażeń, gdyż jedynie ciąg powiązań między obrazami składa się na organiczną strukturę obrazowania u Szekspira.

Interesujące spostrzeżenia na temat dramatu czyni Molly Maureen Mahood, pisząc w Shakespeare's Wordplay (1968):

Dla renesansowego audytorium Hamlet musiał być przede wszystkim dramatem sensacyjnym w znaczeniu, jakie [współcześnie] nadałby mu plakat filmowy. Jest to historia detektywistyczna: prawie każdy jest uwikłany w jakąś formę wywiadowczą. Horacjo, Marcellus i Bernardo próbują odkryć przyczynę nawiedzeń przez ducha. Poloniusz bez problemów otrzymuje od Ofelii klucz do jej pamięci oraz wyznacza szpiegów swojego syna Laertesa [...] (111).

Popularność dramatu Hamlet również może mieć związek z obfitującą w wątki szpiegowskie fabułą dramatu. Choć najsłynniejszym fikcyjnym detektywem o światowej sławie pozostaje Sherlock Holmes, Hamlet, nie będąc zawodowcem, przejawia skłonności śledcze. Metody, jakimi się posługuje np. wykorzystanie sztuki „Morderstwo Gonzagi”, można postawić na równi ze sposobami dochodzenia do prawdy, czyli logicznym dochodzeniem śledczym, stosowanym przez Holmesa. Hamlet odnosi sukcesy na tym polu, czego nie można powiedzieć o większości postaci, które podejmują się szpiegowania na dworze elsynorskim.

Rosencrantz i Guildenstern prowadzą śledztwo w sprawie melancholii Hamleta, a Ofelia zostaje wykorzystana jako wabik, mający odsłonić przyczyny tej melancholii. Hamlet prowokuje króla, by ten ujawnił się w trakcie inscenizowanej przez aktorów zbrodni. Poloniusz podsłuchuje z tragicznym [dla niego] skutkiem, Hamlet będąc na morzu dowiaduje się o spisku na jego życie, Laertes w sekrecie powraca do Danii i obserwuje dwór, by dowiedzieć się, kto jest winny śmierci jego ojca (111).

W najdłuższym ze swoich dzieł dramatycznych Szekspir obrazuje kulturę percepcyjną czasów, w których żył. Sensoryczny kod Hamleta, za pomocą którego portretuje ową kulturę, ma podłoże społeczno-kulturowe, w jakim tworzył dramaturg. Kultura okresu wczesnonowożytnego może zostać odebrana jako kultura owładnięta obsesyjnymi praktykami podpatrywania i podsłuchiwania, a także przepełniona często sprzecznymi wartościami przypisywanymi zmysłom. Dlatego też tak ważnym składnikiem niniejszej pracy, jednocześnie fascynującym z punktu widzenia współczesnego podejścia do świata zmysłów, uczyniłam liczne koncepcje teoretyczne, umożliwiające zrozumienie tragedii Szekspira w kontekście jego epoki. Do dziś wiele 
założeń wypracowanych w tym liminalnym okresie stanowi fundament obowiązującej systematyzacji i kategoryzacji zmysłów, zarówno pod względem ich ważności, jak i przypisywanym im wartościom, na przykład genderowym.

\section{„Źle się dzieje w państwie duńskim" - percepcyjne konsternacje wokół zjawisk nadprzyrodzonych}

Rozgrywająca się na dworze duńskim tragedia otoczona jest poznawczą aurą niepewności, niewiedzy, niejasności i niedomówień. Począwszy od sekwencji otwierającej sztukę Szekspirowską, postaci dramatu niemalże na każdym kroku znajdują się w sytuacji podobnej do położenia strażnika Bernarda, kierującego pytanie „Kto tam?” (1.1.1) w stronę, skąd dochodzą niepokojące odgłosy nocy. Przypuszczalnie, ze względu na panującą dookoła ciemność, oficer zmierzający na zmianę warty bazuje raczej na tym, co słyszy, bo spowita nocą okolica uniemożliwia mu dostrzeżenie obecnego na zmianie warty Franciszka. Noc, oprócz dosłownego wpływu na postrzeganie, polegającego na „upośledzeniu” zmysłów, które skuteczniej funkcjonują w ciągu dnia, posiada też metaforyczną wymowę. Sugeruje ona kondycję umysłową człowieka, który znajduje się w stanie dezorientacji, niepewności i zagrożenia manipulacją ze strony innych. W Hamlecie ciemność nocy może oznaczać niepokój mentalny (figuratywny) oraz percepcyjny (literalny), jaki stopniowo ogarnia mieszkańców Elsynoru. Atmosfera nocy wprowadza napięcie oraz nastrój niesamowitości i grozy, przez co może zapowiadać, że w sztuce będą się pojawiać reprezentacje niezwykłych doświadczeń sensorycznych bohaterów.

Sfera wrażeniowa zostaje zatem wyeksponowana już na wstępie. Choć wszelkie zmysły funkcjonują równocześnie, to jednak organ słuchu zostaje wyróżniony jako ta sfera, która powinna dostarczyć wiedzy bazującej na docierających do Bernarda dźwiękach. Organ wzroku wydaje się znajdować na drugim planie, ponieważ niesprzyjająca mu ciemność utrudnia odbieranie bodźców. Trudności percepcyjne pojawiające się na początku dramatu zauważa McDermott, która zwraca uwagę również na kluczowe znaczenie postrzegania słuchowego dla wzajemnego rozpoznawania się przez postaci dramatu („Perceiving Shakespeare”). Oprócz dających się złowić uchem dźwięków zbliżających się kroków, słychać też odpowiedź na zapytanie Bernarda. Franciszek reaguje chęcią zidentyfikowania męskiego głosu, dlatego kieruje w jego stronę żądanie „przedstawienia się”: „Nie, to wy mi odpowiedzcie; / Stójcie, powiedzcie hasło!” (1.1.2-3). W wersji angielskiej brzmi to: „Nay, answer me. / Stand and unfold yourself." (1.1.2), przy czym „unfold” posiada znaczenie „wyjawiać, ujawniać”. Słowo to pojawia się później dwukrotnie 
w kluczowym momencie rozmowy Hamleta z duchem ojca, podczas której widmo wyjawia przyczynę swojej śmierci, lecz wstrzymuje się od ujawnienia szczegółów o miejscu, skąd przybywa. Z kolei wers zawierający „unfold yourself" oznacza polecenie odkrycia/ujawnienia się przez Bernarda. McDermott sądzi, że Szekspir w tym miejscu wprowadza stychomytię, opierającą się na werbalnym ożywieniu dialogu poprzez szybką wymianę ripost („Perceiving Shakespeare”). Jest to wręcz „pojedynek na słowa”, a jego skuteczność leży przede wszystkim w wartkiej fragmentaryczności wypowiedzi oraz w podkreśleniu napięcia, które towarzyszy bohaterom od samego początku sztuki. Werbalność, a przez to słuchowość fragmentu rozpoczynającego dramat, wskazuje na dowartościowanie w tym miejscu konwencji narracyjnej, którą Szekspir często posługiwał się w dramatach.

W artykule "Narratives, Narrators and Narratees in Hamlet" Robert R. Wilson zwraca uwagę właśnie na narracyjny wymiar tragedii, doceniając jej literackie walory. Według badacza opowieści snute przez różnych bohaterów pojawiają się w dramacie niczym „[p]olifoniczna aranżacja głosów, z których każdy opowiada jego (albo jej) odrębną historię, tworzącą dramat Szekspirowski" (1984: 30). Wilson wyróżnia w ramach wymiaru narracyjnego dramatu postać narratora i słuchacza lub słuchaczy, którzy są „karmieni” prawdziwymi lub zafałszowanymi opowieściami. Zapotrzebowanie na opowieści w Hamlecie badacz tłumaczy ogólnym stanem dezorientacji poszczególnych postaci. Zdezorientowanie to poniekąd jest wywołane pojawieniem się zjawy na samym początku sztuki. Jak podaje Wilson: „Hamlet rozpoczyna się podwójną akcją: ludzie wpatrują się w ciemność i zadają pytania. Ciemność, wpatrywanie się i zadawanie pytań przeplatają się w sztuce. Hamlet wydaje się zadziwiający pod względem liczby zadawanych pytań" (33). Wilson mówi o ponad czterystu bezpośrednich pytaniach gramatycznych oraz wielu dodatkowych - w postaci zagadek, łamigłówek i aporii - przewijających się w dramacie. Pytania stawiane wprost i niebezpośrednio wielokrotnie wymagają narracyjnych odpowiedzi. Jeśli pada jakieś pytanie, pojawia się też albo prośba, albo nawet żądanie wyjaśnienia w formie opowieści (33). Tak dzieje się w przypadku „inicjacyjnej” rozmowy między wartownikami zamku elsynorskiego.

Jeśli uznać, że w Hamlecie „na początku było słowo” i ciemność, to można pokusić się o stwierdzenie, że to właśnie „słowo” ową ciemność rozjaśniło. Wyjaśniająca moc języka „oświetla drogę” bohaterom niczym latarnia morska. Paradoksalnie zatem ucho „oświeca” oko. Wydaje się, że percepcja słuchowa - aktywizowana przez różnego rodzaju opowieści i rozmowy, ale także przez wszelkie dźwięki i hałasy - ma większą siłę eksplikacyjną w stosunku do nieradzącej sobie z mrokiem percepcji wzrokowej. Tylko pozornie związek między głosem a uchem jest relacją sprawiającą wrażenie relacji doskonałej, pozbawioną wypaczeń, chaotyczności i przemocy. Rację ma Kenneth Gross, twierdząc, że: 
Nagminnie występujące w sztuce narządy zmysłu słuchu są złaknione [słów], ale także podatne na zranienie [tymi słowami]. Czasami są otwarte w ostrożny sposób lub otwierane w wyniku wywieranej nań presji. Są także narażone na zranienie (słowami żywych lub umarłych. Mogą też doznać uszkodzenia przez to, co jest powiedziane, i przez to, co nie jest powiedziane - jakby były spragnione toksycznych słów lub pustej gadaniny, zamiast racjonalnego wyjaśnienia). Krytycy zwykle komentują liczne wyobrażenia zranionych, otrutych, zblokowanych, przeklętych, rozdartych i zainfekowanych uszu w sztuce (2001: 13).

Wobec tego można poczynić refleksję, że reprezentacje słuchu, pojawiające się uparcie w Hamlecie, niejednokrotnie świadczą o podatności ucha na uszkodzenia i manipulację. Jednocześnie może ono pozostać dostępne dla dźwięków płynących z otoczenia.

W scenie rozpoczynającej dramat można zauważyć wspomnianą już tendencję do faworyzowania percepcji słuchowej i oparciu o nią kluczowych wydarzeń w sztuce, inicjowanych opowieściami o przeszłych zdarzeniach. Zatem organem, który Szekspir „obdarowuje” szczególną uwagą, są uszy. Dzięki nim dochodzi też do wzajemnego rozpoznania między Franciszkiem i Bernardem oraz kolejnymi przybyłymi postaciami: strażnikiem Marcellusem i Horacjem - przyjacielem Hamleta. Ponownie postrzeganie wzrokowe jest ograniczone przez ciemność nocy, przez co identyfikacja postaci odbywa się inną drogą - kanałem słuchowym. Marcellus i Bernardo zaczynają niemalże od razu dzielić się wrażeniami percepcyjnymi związanymi z pojawieniem się na zamku zjawy. By wyrazić swe osłupienie wizualne, każdy po kolei próbuje wywołać zdziwienie u słuchaczy. Jednak w swoich relacjach podkreślają oni znaczenie zmysłu wzroku jako podstawowego organu informującego o pojawieniu się zjawy. Zagrożeniem i lękiem napawa bohaterów fakt, że poleganie na zmyśle słuchu okazuje się chybione w sytuacji bezszelestnego ukazania się widziadła.

Dalsza wymiana spostrzeżeń obfituje w słownictwo percepcyjne związane ze wzrokiem. Bernardo, zapytany przez Marcellusa: „I coż, zjawiło się znów tej nocy?” (1.1.21), udziela takiej odpowiedzi: „Nic nie widziałem” (1.1.21). W toku rozmowy Marcellus ujawnia, że:

Horacjo twierdzi, że to tylko nasza

Fantazja, i nie daje się owładnąć

Wierze w to groźne widmo, już dwukrotnie

Widziane przez nas. Przeto go prosiłem,

Ażeby razem z nami przestrażował

Minuty nocy, a gdy się raz jeszcze

Pokaże zjawa ta, potwierdził naszych

Oczu świadectwo i przemówił do niej (1.1.23-30)².

\footnotetext{
${ }^{2}$ Wszelkie wyróżnienia kursywą w cytowanych fragmentach z Hamleta są autorki.
} 
Warto tutaj zwrócić uwagę na wyjątkowe znaczenie zmysłów dla czynności, jaką jest pełnienie warty. Wydaje się, że Szekspir celowo na postacie wprowadzające w akcję dramatu wybrał wartowników, których powinnością jest, by mieli uszy i oczy szeroko otwarte. McDermott wskazuje, że ,jako słuchacze muszą uważnie nasłuchiwać dźwięków niosących nocą niebezpieczeństwo i postrzegać je jako zagrożenie, którym są, albo zlekceważyć je jako nieszkodliwe, jedynie jako »chrobotanie myszy« (1.1.8)”. Badaczka zauważa, że z kolei „jako obserwatorzy wątpią we wnikliwość swoich oczu” („Perceiving Shakespeare”). Spostrzeżenie to potwierdza zacytowany powyżej fragment, w którym można odnaleźć pierwsze - spośród ogólnej liczby 38 - bezpośrednie odwołanie do oczu. Prawdopodobne, że w tym miejscu Szekspir zasygnalizował niejednoznaczne kulturowe podejście do percepcji wizualnej, objawiające się między innymi zwątpieniem w autentyczność przekazu wzrokowego.

Ciekawe, że to właśnie informacje płynące od zmysłu wzroku wywołują sceptycyzm tak samo u tych strażników, którzy spotkali się ze zjawą, jak u Horacja, który „nie dowierza” oczom kolegów. Stąd jego zadanie, polegające na potwierdzeniu świadectwa oczu Bernarda i Marcellusa. Wyłaniająca się reprezentacja percepcji wizualnej ukazuje raczej słabości ludzkiego wzroku aniżeli jego siłę. Oko, będące kluczowym narzędziem poznania, okazuje się organem narażonym na manipulację. Poleganie jedynie na dowodach wizualnych wiąże się w tym przypadku z dostarczeniem wiedzy wątpliwej. Ponadto istnieje możliwość pomieszania „obrazu realnego" z „obrazem imaginacyjnym", czyli wytworem wyobraźni, przed czym przestrzega kolegów Horacjo. Można też odczytać ten fragment jako próbę dokonania rozróżnienia przez Szekspira pomiędzy „okiem ciała” $i$ „okiem umysłu”, przy czym to drugie miałoby właściwości „oka kartezjańskiego”, które postrzega niezależnie od ciała, niczym „oko wyobraźni”.

Należy również podkreślić, że gdyby nie postrzeganie wzrokowe, uszy nie wychwyciłyby bezdźwięcznego przybycia ducha. Niezarejestrowane przez organ słuchowy zjawisko dało się zaobserwować, i chociażby tu widać literacką reprezentację percepcji wizualnej i audialnej, ze zmienną przewagą tej pierwszej nad drugą. Znamienne jest to, że z opowieści wynika, iż duch „urządza niemy spektakl” i nie wyjaśniając swego przybycia, powoduje dodatkową konsternację widzów. Dlatego zadaniem, jakie ma wypełnić Horacjo, jest nawiązanie z nim rozmowy. Zanim jednak to nastąpi, Horacjo usłyszy relację z ujrzenia zjawy, gdzie narratorem Szekspir uczynił Bernarda:

Siądźcie na chwilę i pozwólcie, byśmy Raz jeszcze szturmowali wam do uszu, Obwarowanych tak potężnie przeciw Powieści o tym, cośmy noc po nocy Dwa razy tu widzieli (1.1.32-36). 
Wykorzystanie przez Szekspira odniesienia do narządu słuchu stanowi kolejny element składający się na poetykę zmysłów w Hamlecie. W powyższym fragmencie ukazuje się reprezentacja percepcji słuchowej, przedstawiająca „obwarowane uszy”. Są one zabezpieczone „fortyfikacją” i dlatego muszą być „brane szturmem”. Uszy „bronią się” przed niechcianymi słowami i nie dopuszczają ich do siebie.

W pracy Double Vision: Moral Philosophy and Shakespearean Drama (2007) Tzachi Zamir zwraca uwagę na ustawicznie pojawiające się w dramacie nawiązania do języka sensorycznego, przy czym szczególnym zainteresowaniem obdarza on słownictwo związane ze słyszeniem. Badacz eksponuje fundamentalną różnicę pomiędzy funkcjami, jakie uszy i oczy spełniają w Hamlecie, mianowicie dostępność do wnętrza ciała poprzez otwartość organu audialnego. Autor metaforycznie przyrównuje ucho do jednego z kluczowych otworów ciała, pisząc, że w Hamlecie:

Ciało jest porównane do miasta, do którego wejście prowadzi przez ucho. Zastosowanie przez Szekspira słu chowego obrazowania łączy się z niektórymi renesansowymi koncepcjami anatomicznymi i fizjologicznymi, dotyczącymi słuchania jako procesu przedostawania się [czegoś] do wnętrza ciała. Zainteresowanie narządem słuchu ilustrują traktaty anatomiczne i muzykologiczne, wielokrotnie przywołując architekturalne obrazowanie, które zachęca do badań za pośrednictwem specyficznych aluzji do penetracji (2007: 168).

Przytaczając przykłady z renesansowych tekstów, Zamir twierdzi, że wewnętrzna budowa uszu jest w nich wyobrażana na wzór konstrukcji architektonicznej budynków. Są zatem portretowane jako różne wejścia i wyjścia, jak na przykład drzwi czy okna, przejścia w postaci korytarzy oraz pomieszczenia, takie jak pokoje i komnaty. U anatoma Mondina de Lucciego znajduje Zamir odwołanie do „zakręconego otworu/jamy”, obecnego w uchu; u Volchera Coitera występuje opis procesu słuchania, gdzie dźwięk przechodzi przez meandry i zakręty uszu; Helkiah Crook wspomina nawet o dźwięku, który trafia do labiryntu, jakim jest organ słuchu; zaś Thomas Willis dodaje, że architekci mogliby wykorzystać i skopiować plan budowy ucha do projektów konstrukcyjnych (168). Zafascynowanie strukturą wewnętrzną ucha niosło za sobą konsekwencje nie tylko w postaci uznania budowy tego narządu za wzór nadający się do przeniesienia w inną dziedzinę naukową. Ucho również było organem mającym bezpośredni związek z wnętrzem człowieka.

Zdaniem Zamira, potencjał tkwiący w sile oddziaływania dźwięków na słuchacza miał właściwości transformacyjne, a nawet owładniające (2007: 169). Percepcja audialna miała stanowić alternatywę dla percepcji wizualnej, której niektórzy badacze kultury renesansu przypisują nadrzędny status w hierarchii zmysłów. Ścisły związek między postrzeganiem słuchowym i wywieraniem wpływu na odbiorcę dźwięków oddają sformułowania, które autor przytacza w celu pokazania ich „brutalności” i gwałtowności. Chodzi tu 
o terminy (stosowane w odniesieniu do funkcji, jaką odgrywa dźwięk w percepcji audialnej), takie jak: uderzać, porwać, wciskać oraz zawładnąć (169). Motyw wtargnięcia i wniknięcia w głąb ciała poprzez ucho stanowi jedno z uzasadnień dla uznania słuchu za zmysł bardziej wewnętrzny. To z kolei może prowadzić do przyjęcia założenia, że ciało, będące bardziej otwarte na bodźce audialne, umożliwia najgłębszy i najpełniejszy kontakt pomiędzy tym, co dociera z zewnątrz a umysłem.

W artykule „Lend Thy Serious Hearing to What I Shall Unfold: Legend Dynamics in Hamlet" Charles Gregg Kelley wspomina, że historia, jaką przedstawia wartownik, to „opowieść o duchach ze stylizowaną narracją” (1999: 90). Celem Bernarda jest przekonanie Horacja o jej prawdziwości, dlatego jego „narracja posiada cechy prawdziwej historii, czy też bardziej precyzyjnie, historii opowiedzianej jako prawdziwa" ([podkreślenie autora] 90). Wiarygodność przekazu jest o tyle istotna, że odbiorca opowieści podchodzi do niej sceptycznie. Ważne jest przy tym zasygnalizowanie przez Szekspira, że Horacjo częściowo zna tę opowieść, bo zaraz po swoim przybyciu kieruje takie oto pytanie do pozostałych strażników: „I cóż, zjawiło to się znów tej nocy?” (1.1.21). Zdaniem autora artykułu, oznacza to, że

pytanie Horacja jest zdefragmentowaną aluzją do bardziej rozbudowanej opowieści o duchach, która najwyraźniej stanowi już część wspólnego grupie układu odniesienia. Nie ma powodu, by Horacjo wydobywał jasne szczegóły dotyczące wcześniejszego przybycia ducha, ponieważ są one powszechnie znane z poprzednich opowieści, a wyraźna defragmentaryzacja owych pełniejszych opowieści pokazuje, że historia jest już identyfikowana i funkcjonuje wśród tej grupy ludzi (1999: 90).

Na potwierdzenie tego Bernardo używa sformułowania o ponownym „szturmowaniu uszu słuchacza”, czyli odwołuje się do historii o duchu po raz wtóry. Ewidentna staje się tu rola percepcji audialnej, która w przypadku Horacja okazuje się czynnie sterowanym mechanizmem, umożliwiającym świadome odrzucanie wątpliwych treści. Szekspir tak zaprojektował pierwszą scenę dramatu, by Horacjo został wciągnięty w „krąg wtajemniczonych” i zaczął operować językiem adekwatnym do komentowanego zajścia, na przykład „zjawiło to się”. Jak zauważa Kelley, Horacjo zdaje sobie sprawę, że opowieści o duchach zawierają element legendarny, przez co ich oddziaływanie sprowadza się do zaangażowania słuchaczy w rozmowę co do ich wiarygodności (90).

Funkcjonowanie legendy w kontekście kulturowym odbywa się dzięki jej powtórnym werbalnym odtworzeniom, a nawet przetworzeniom. Szekspir wykorzystuje tutaj narracyjny zabieg rekonstrukcji wydarzeń, z wplecionymi w nie elementami podania. W efekcie Bernardo nie tylko szykuje się do stworzenia przekonującej opowieści ze względu na to, co zobaczył, ale także dba o zachowanie konwencji legendy, mającej wywrzeć wrażenie na słucha- 
czu. Autor Narrating the Visual in Shakespeare stoi na stanowisku, że epicki styl występujący na początku opowieści Bernarda, zapowiada raczej przemyślaną, powolną i przydługą narrację (2009: 85). Ostatecznie jednak Szekspir nadaje jej następujący kształt:

\author{
Ostatniej nocy, \\ Gdy gwiazda ta na zachód od bieguna \\ Tę stronę nieba oświecała w biegu, \\ Gdzie teraz płonie, myśmy z Marcellusem \\ W chwili, gdy pierwsza biła na zegarze... (1.1.38-42).
}

Drobiazgowe wprowadzenie $\mathrm{w}$ atmosferę zjawienia się ducha przerywa jego „realne” przybycie oraz polecenie Marcellusa, by Bernardo zamilkł. Meek podejrzewa, że opowieść wartownika rozwinęłaby się w rozbudowaną narrację, jednak nagłe ukazanie się ducha zmienia opowieść w widowisko (2009: 85). Ponadto pierwsza scena tragedii stanowi, według Meeka, swego rodzaju powtórzenie tego, co już zaszło. W opinii badacza, „wszystko w tej scenie rozgrywa się tak, jakby stanowiło powtórkę czegoś innego lub spóźnioną wersję oryginału. Postacie mówią o dziwnych wydarzeniach, jakich doświadczają, jak gdyby już się wydarzyły" (84). Następuje powielenie zaszłych zdarzeń, więc opowieść Bernarda to poniekąd „widmo opowieści o widmach” (85).

Można też wysunąć stwierdzenie, że narracja staje się czynnikiem sprawczym pojawienia się ducha. Interpretację taką sugeruje Meek, dodając, że istnieje jeszcze inna możliwość, a mianowicie, iż opowieść Bernarda staje się zbędna i mało autentyczna wobec „realnego” przybycia zjawy (2009: 85). Pojawia się zatem wątpliwość, czy przewagę ma spektakularne ukazanie się ducha, czy werbalny przekaz wartownika. Związek pomiędzy tym, co widziane, a tym, co słyszane, nabiera szczególnego znaczenia. W ocenie Kelleya za pomocą ostensji narracja przeradza się w uwidoczniony „fakt”. W Hamlecie słowo zostaje „ucieleśnione” w postaci ducha. Wizualny wymiar sztuki zaczyna dominować nad werbalnym, a nawet „narracja jest zastapiona przez akcję, to znaczy, że słowa są zastąpione czynami” ([podkreślenie autora] 92).

Pojawienie się ducha powoduje pobudzenie percepcji wizualnej, stwarzając możliwość potwierdzenia przez wartowników wcześniejszego świadectwa ich oczu. Z kolei dla Horacja jest to szansa na zmianę jego sceptycznego podejścia do opowieści Bernarda. Można powiedzieć, że w tym przypadku oddziaływanie obrazem na zmysł wzroku ma większe znaczenie niż oddziaływanie opowieścią na zmysł słuchu. Szekspir przemienia nieufnego Horacja w bazującego na tym, co widzą jego oczy, świadka zdarzenia:

Na Boga, nie dałbym ja temu wiary, Gdyby nie bezpośrednie i rzetelne Świadectwo oczu mych (1.1.62-64). 
W powyższym cytacie warte zaakcentowania wydają się: naoczność oraz uważne zaangażowanie percepcji wizualnej w proces widzenia. Weryfikują one autentyczność tego, co jest obserwowane. Taka literacka reprezentacja percepcji wizualnej może sugerować, że oko jest bardzo miarodajnym narzędziem wiedzy. Thorne uważa, że „[j]est to nośnik, dzięki któremu hipotezy odnoszące się do natury rzeczywistości, mogą być poddawane próbie oraz w demonstracyjny sposób potwierdzone albo obalone" (2000: 110). Tak dzieje się w przypadku nakłonienia Horacja do uczestnictwa w wieczornym sprawowaniu warty, podczas którego ukazuje się duch. Niemy spektakl zjawy jest swego rodzaju pantomimą, bo duch powstrzymuje się od wszelkiej komunikacji werbalnej. I choć jego wizualna obecność „przemawia do oczu” świadków, to jednak pojawiają się wątpliwości dotyczące zwodniczej i iluzorycznej natury ducha. Zatem podejście do percepcji wizualnej znowu okazuje się dwuznaczne. Obserwatorzy zjawisk zostają tutaj tak ukazani przez Szekspira, jakby mogli być narażeni na zwodzenie przez omamy wzrokowe.

Przyobleczenie się w królewską postać (przez ducha) może być pozorne, dlatego warunkiem koniecznym staje się nawiązanie rozmowy ze zjawą. Według Meeka epistemologiczny status ducha pozostaje niepewny i niesprecyzowany (2009: 86). Stąd ponaglenie Bernarda skierowane do Horacja: „To widmo czeka, by doń przemówiono" (1.1.48) oraz podobne słowa Marcellusa: „Horacjo, stawże mu pytania!” (1.1.49). Żołnierz najpierw dwukrotnie odzywa się do postaci przypominającej zmarłego króla, wołając: „Klnę cię w imię niebios, / Odpowiedz!” (1.1.54-55) oraz „Stój i przemów! / Przemów, ja tobie nakazuję, przemów!" (1.1.57-58). Zostaje jednak zignorowany przez ducha, który znika, sprawiając wrażenie, że słowa go spłoszyły. Mimo wszystko widziadło objawia się ponownie, przerywając rozmowę między czujnymi mężczyznami i prowokuje kolejną reakcję werbalną Horacja:

Stój, złudne ty widziadło! Jeśli

Wydobyć możesz głosu dźwięk i mówić,

To przemów do mnie!

Jeżeli trzeba ci dobrego czynu,

Co tobie dałby ulgę, mnie zasługę,

To przemów do mnie!

Jeżeliś świadom ciężkich nieszczęść kraju,

Które dziś znając można by odwrócić,

To przemów!

Lub jeśliś za żywota w łonie ziemi

Ukrył wydarte skarby - a wy, duchy,

Pono błąkacie się po śmierci za to -

Pieje kur.

To powiedz! Stój i przemów! (1.1.150-162). 
Nawoływania Horacja pozostają bez odzewu - duch powtórnie znika, natomiast widzowie spektaklu komentują zaobserwowane zdarzenia. Przede wszystkim winą za ulotnienie się ducha obarczają piejącego koguta. Co ciekawe, Horacjo i Marcellus odwołują się do popularnych przekonań na temat piania koguta, na którego znak „wraca błędny duch do swojej / Siedziby” (1.1.178-179). Używają sformułowań: „słyszałem ja” (Horacjo), „niektórzy mówią" (Marcellus), i tym samym podtrzymują przekazywane słownie legendarne wyobrażenia o duchach. Przypominają rozpowszechnioną wiedzę na ich temat i utwierdzają się w autentyczności tego, co widzieli. Z drugiej strony, może być i tak, że opinia zostaje potwierdzona przez zdarzenie. Wynika to z wypowiedzi Marcellusa, który najpierw odwołuje się do zbiorowych przekonań, a następnie wysnuwa wniosek: „Że to prawda, przekonywa / Rzecz, co tu zaszła" (1.1.177-178). Tym samym Szekspir po raz kolejny demonstruje swój niedookreślony stosunek do zmysłów i uzewnętrznia - na poziome tekstu - wczesnonowożytne rozterki dotyczące statusu słuchu i wzroku w kulturze. Meek stoi na stanowisku, że pierwsza scena aktu pierwszego „daje pierwszeństwo dramatycznej „natychmiastowości” względem słownych narracji, a dodatkowo Szekspir wyraźnie zwraca naszą uwagę na potencjalną zwodniczość tego, co się ukazuje. Sugeruje nawet, że to, co widzimy, może być zależne od opowieści" (2009: 88).

Jak pokazuje dalszy rozwój akcji w sztuce, jej autor kontynuuje tę strategię. Polega ona nie tylko na zdawaniu relacji z zaskakujących wydarzeń przez poszczególnych bohaterów, ale także na wplataniu ich w szerszy kontekst kulturowych opowieści, między innymi - o duchach. Ostatecznie Horacjo ogłasza:

Donieśmy o tym, cośmy tu widzieli

Młodemu Hamletowi. Na me życie,

Przemówi doń ten duch, choć niemy dla nas (1.1.195-197).

Wahania pomiędzy ustaleniem statusu przekazów wizualnych i werbalnych ustanawiają kod sensoryczny w Hamlecie. Caldwell zauważa, że nawiązania do organów wzroku i słuchu przenikają całą sztukę, lecz mniej „rzucają się w oczy” niż często analizowane wątki zepsucia (1979: 139). 0 „prawie obsesyjnej serii aluzji do oczu, uszu i aktu postrzegania" (139-140) wspomina badacz w artykule, w którym przywołuje już pierwszą scenę dramatu. Pojawienie się ducha to dla świadków zjawisko graniczące z podejrzeniem o pomieszanie zmysłów. Przekonanie nieobecnego Horacego, że zmarły król Hamlet objawił się dwóm strażnikom w trakcie nocnej warty, opiera się na dialogu, wykorzystującym zwroty związane z postrzeganiem zmysłami. Caldwell pisze, że obaj zwracają uwagę na siłę oddziaływania zjawy na ich zdolności percepcyjne, „przez co odwołania do zmysłów stają się dominują- 
cą częścią języka w owej scenie" (1979: 140). Badacz zwraca uwagę, że oto w pierwszej scenie pierwszego aktu można zaobserwować wzmożony nacisk na odwołania do percepcji sensorycznej, akcentujące widzenie i słyszenie (140). Pierwsza scena to także zapowiedź dalszej dezorientacyjnej „gry” pomiędzy wzrokiem i słuchem, która stanowi podstawowy element poetyki zmysłów obecnej w Hamlecie.

\section{Między prawda a fałszem, autentycznością a pozorem - relacje między bohaterami}

W drugiej scenie akcja dramatu zostaje przeniesiona do głównej komnaty zamku elsynorskiego, gdzie ma miejsce wystąpienie Klaudiusza, nowego króla Danii. Jego przemowa ma przede wszystkim charakter perswazyjnego oddziaływania na słuchaczy, wśród nich również na Hamleta. Klaudiusz tworzy własną opowieść, tłumaczącą jego decyzję poślubienia wdowy po zmarłym bracie oraz przejęcia jego obowiązków jako głowy państwa. Od chwili koronacji Klaudiusz posiada autorytet monarchy, pozwalający mu na szczególne wywieranie wpływu na słuch swoich poddanych. Jak podaje Robert R. Wilson, naświetlenie „faktów” przez nowego władcę "jest skażone osobistym wkładem Klaudiusza w narrację" (1995: 34). Jest to na pozór niewzbudzające wątpliwości przemówienie nowego króla, stylizowane na podniosłą mowę, która dla opisu sytuacji Danii zawiera metaforyczne słownictwo z zakresu cielesności. Zdaniem autorki Shakespeare's Knowledgeable Body (2008), Marthy Diede, wyrażenia związane z ciałem politycznym są eksploatowane przez Klaudiusza od samego początku jego wypowiedzi, choćby w momencie, gdy mówi: „I serca nasze winny by w głębokim / Być pogrążone smutku, całe nasze / Królestwo zasępione być jak jedno / Bolesne czoło" (1.1.205-207) (109).

Ustanawiające nowy porządek $\mathrm{w}$ państwie wystąpienie władcy ma na celu zaskarbienie uwagi poddanych - przekonanie ich do siebie, przede wszystkim przez moc słowa docierającego do ich uszu. By wyjaśnić decyzję o koronacji oraz małżeństwie z Gertrudą, Klaudiusz odwołuje się do języka somatycznego, ogłaszając że:

Przeto, jeżeli można tak powiedzieć, $\mathrm{Z}$ unicestwioną wesołością, z jednym Radosnym, drugim zapłakanym okiem, $\mathrm{Z}$ radością pogrzebową i żałoby Weselnym hymnem, na tej samej szali Ważąc uciechę oraz ból - za żonę Pojęliśmy tę naszą dawniej siostrę (1.2.211-217). 
W powyższym fragmencie Szekspir tak „ułożył” wystąpienie Klaudiusza, by nie pojawiło się w nim, ani razu odwołanie do percepcji audialnej, ani wprost - do uszu. Być może jest to zabieg celowy, by uniknąć przywołania tego - jak się okaże - newralgicznego dla Klaudiusza rejonu ciała oraz związanej z nim zdolności postrzegania. Być może sportretowanie percepcji wzrokowej poprzez bezpośrednie odniesienie do organu wzrokowego jest odwróceniem uwagi od dosłownie i przenośnie zatrutych przez Klaudiusza uszu zmarłego brata oraz całego „politycznego ucha” Danii. Opowieść Klaudiusza, choć skierowana do uszu zebranych w sali zamkowej, o nich samych milczy przypuszczalnie celowo.

Wspomniana już literacka reprezentacja zmysłu wzroku oddaje jego ścisłe połączenie ze sferą refleksyjno-emocjonalną. Zwrot „z jednym / Radosnym, drugim zapłakanym okiem" jest przykładem na użycie narządu wzroku w powiązaniu z personifikującymi przymiotnikami. Radość i smutek są przejawami wewnętrznych przeżyć, a ich uzewnętrznienie dokonuje się poprzez odpowiednią mimikę i wydzieliny płynące z oczu. Człowiek ma zatem możliwość wyrażenia swoich uczuć oczami, jak gdyby same były organami emocji i refleksji. Owo wyjątkowe potraktowanie organu wzroku nadaje im wyższą rangę niż narządowi słuchu, albowiem ten nie posiada możliwości uronienia łzy ani okazania wesołości.

Można także zinterpretować ten wers jako zasugerowanie przez Szekspira jawnej łączności pomiędzy organem wzroku i wnętrzem/duszą/umysłem. Biorąc pod uwagę renesansową teorię sensoryczną, bazującą na podejściu przedkartezjańskim, percepcja wizualna jest tutaj potraktowana w kategoriach psychosomatycznych. Podszyte emocją, radosne i zapłakane oko byłoby więc jednocześnie organem uczuć wewnętrznych, jak i sfery fizjologicznej. Wzrokowe oznaki stanów wewnętrznych miały kluczowe znaczenie w rozpoznawaniu stanów psychicznych innych ludzi ${ }^{3}$.

Choć jedynie oko posiada zdolność, by zewnętrznie wyrazić swój ścisły związek z wnętrzem, to niezaprzeczalnie równie ważna u Szekspira jest nierozłączność między duszą i uchem. Zamir kilkakrotnie odwołuje się do wczesnonowożytnych przekonań na temat zmysłu słuchu, które potwierdzają tezę o doniosłości tego zmysłu w procesie poznania. Badacz cytuje też starożytnych myślicieli, których koncepcje zostały utrwalone w renesansie, a wśród nich Boecjusza, stojącego na stanowisku, że tylko drogą słuchową nauka dociera do umysłu w sposób najbardziej otwarty. Zamir zauważa jednocześnie, że jeszcze wcześniej Arystoteles, choć przyznawał wyższość wzroku nad słuchem w zakresie pierwotnych potrzeb życiowych, to jednak udzielił pierwszeństwa percepcji audialnej w kwestii rozwoju intelektualnego (2007:

\footnotetext{
${ }^{3}$ Wiązało się to z fundamentalną kwestią dotarcia do prawdy o drugim człowieku. Kwestią wręcz obsesyjnie eksploatowaną w różnego rodzaju tekstach kulturowych tego okresu, która zostanie omówiona w dalszej części rozdziału.
} 
169). Ponadto zmysł słuchu miał ze szczególną przenikliwością docierać do duszy, co stawiało go ponad innymi (168).

Z kolei Penelope Gouk w artykule „English Theories of Hearing in the Seventeenth Century" opisuje liczne renesansowe teorie na temat percepcji słuchowej. Pytania, które stawiali sobie ówcześni badacze, częściowo postawili już starożytni. Badaczka potwierdza, że wiele poglądów zaczerpnięto z popularnej myśli starożytnej, zwłaszcza arystotelesowskiej i galenowej (2004: 136) ${ }^{4}$. Przywołuje tu pracę Crooke’a Microcosmographia z 1615 roku, która jako pierwszy angielski anatomiczny opis zmysłu audialnego, podaje szczegółowe objaśnienia dotyczące funkcjonowania narządu słuchu. W owym dziele anatom podkreśla też szczególne znaczenie percepcji audialnej w procesie poznania, zwłaszcza jej wpływ na umysł i inteligencję. Gouk podaje, że zdaniem Crooke’a, dzięki temu, iż to, co słyszane, oddziałuje bardziej sugestywnie na umysł, dużą rolę $w$ procesie poznania i zdobywania informacji pełni narracja (139). W tym względzie słuch przewyższa wzrok, o czym zdawał się wiedzieć Szekspir, wykorzystując tę koncepcję i między innymi kreując postać Klaudiusza na prawdomównego i przekonywającego mówcę.

Scena druga, wkrótce po zakończeniu przemowy nowego władcy, rozwija się w rozmowę Klaudiusza, Gertrudy i Hamleta. Dochodzi do konfrontacji pomiędzy parą królewską z jednej strony a Hamletem - z drugiej. Jej celem jest wybadanie i ocena stanu emocjonalnego księcia, na co może wskazywać pytanie Klaudiusza: „I czemuż wciąż nad wami wiszą chmury?” (1.2.290). Z kolei matka zwraca się do oszczędnego w słowach syna z taką oto sugestią:
Dobry Hamlecie, zrzuć te barwy nocy
I patrz na króla przyjaźniejszym okiem;
$\mathrm{Z}$ opuszczonymi na dół powiekami
Rozglądać w prochu przestań się za ojcem.
Wiesz, że to rzecz zwyczajna - ten kto żyje,
Umierać musi i przez ziemskie życie
Przechodzi do wieczności (1.2.291-298).

Okazuje się, że z wyglądu i stylu bycia Hamleta daje się na pierwszy rzut oka wiele wywnioskować. Nim bohater wyjaśni swoje stanowisko, „zewnętrze” będzie jedyną oznaką jego mentalnej kondycji. Baczna obserwacja Hamleta staje się jednym z kluczowych motywów w sztuce.

Szekspir powtórnie uczynił wzrok podstawowym zmysłem służącym do oceny formy psychofizycznej innych. Gertruda dostrzega nieprzychylne i złowrogie spojrzenia kierowane na Klaudiusza, stąd jej prośba, by Hamlet patrzył na niego „przyjaźniejszym okiem”. Jest to pierwsza z kilku rozmów

\footnotetext{
${ }^{4}$ Dodaje ona, że większość tych części ucha, które były „widoczne gołym okiem”, bez użycia mikroskopu, zostały odkryte już przed XVII wiekiem (2004: 139).
} 
o charakterze genderowym, w których każda z płci zajmuje określoną pozycję, przy czym to słowa pochodzące z ust mężczyzny miały w kulturze patriarchalnej renesansu większy autorytet $\mathrm{w}$ porównaniu $\mathrm{z}$ wypowiedziami kobiecymi. Związek między Hamletem i Gertrudą stanowi skomplikowaną relację ze względu na sprawowanie przez nią funkcji królowej oraz matki. Pierwsze „starcie” między matką a synem jest dosyć łagodne, choć pewne elementy dialogu już mogą zapowiadać przyszłą „wojnę na słowa”. Rozmowa, jaka wywiązuje się między nimi, ma charakter komentarza do spostrzeżeń odnoszących się do sytuacji po śmierci króla Hamleta i zachowania, jakie prezentuje Hamlet: „czemu rzecz zwyczajną ową / Przybierasz sobie w postać wyjątkową?” (1.2.300-301). Powyższe stwierdzenie Gertrudy powoduje „odzew" Hamleta:

W postać? Nie, pani, to istota rzeczy. Ja nie wiem, co to postać. To nie tylko Atramentowy płaszcz mój, dobra matko, Ni przepisowo czarna reszta stroju, Nie wiew przemocą wydobytych westchnień, Nie, ni obfitość rzek płynących z oczu, Ni przygnębieniem tchnący wyraz twarzy Wraz ze wszystkimi formy, objawami I oznakami żalu mnie naprawdę Odzwierciedlają - to zaprawdę tylko Zewnętrzna postać, to czynności, które Człowiek odegrać zdolne jest, tymczasem To, co jest we mnie, nad postaci wzlata, Tamto - to tylko smutku strój i szata (1.2.302-315).

Cytowany fragment doczekał się wielu interpretacji ze strony badaczy dzieł Szekspira. Thorne uważa, że jest to rodzaj introspekcji, czyli widzenia nakierowanego na wnętrze, niejako „metoda wyobrażania sobie siebie” (2000: 106). Badaczka wspomina o sposobach, jakie Hamlet w tym celu stosuje, między innymi przywołując metaforę autoportretu. Głównym bodźcem dla tej metody jest przekraczanie granic pomiędzy tym, co ukryte w środ$\mathrm{ku}$, a tym, co wyrażane na zewnątrz. Potrzeba autorefleksyjnego poznania siebie, z tendencją do wyraźnego rozgraniczania na wnętrze i „zewnętrze”, towarzyszy Hamletowi od samego początku. Jednak taka samoobserwacja, podobnie jak w przypadku lustrzanej, wymaga zewnętrznego wobec siebie przedmiotu. Dlatego samoobserwacja jest możliwa, gdy „osoba widzi siebie jako innego, staje się własnym obserwatorem" (107). Thorne skłania się ku poglądowi, że w Hamlecie pojawia się nowy typ „ja” o charakterze kartezjańskim. Będąc podmiotem podzielonym, ,ja” składa się z ,ja” postrzegającego oraz "ja” postrzeganego (107). W takim rozumieniu Hamlet funkcjonuje jako 
postać, która w poszukiwaniu prawdy o sobie i o innych, potrzebuje do tego celu jakiegoś „lustra”. W ocenie Thorne, Hamlet właśnie z tego powodu „zawsze tworzy lustrzane obrazy, których specyficzna funkcja polega na tym, że pozwala mu oraz pozostałym postaciom na wejrzenie w ich »duszy głębie«" (109).

Podobny pogląd na zagadnienie podmiotowości w Hamlecie reprezentuje Nancy Selleck. W pracy The Interpersonal Idiom in Shakespeare, Donne, and Early Modern Culture (2008) badaczka twierdzi, że „Hamlet reprezentuje nową osobistą wrażliwość, która zmierza ku nowoczesnemu »ja« albo podmiotowi" (1). Jej zdaniem, z dramatu wyrasta tożsamość, będąca nie tylko kwestią wewnętrzności bohatera, lecz tego, jak owa „wewnętrzność jest rozmieszczona w społeczeństwie” (16). Selleck sądzi, że podobnie jak w innych tekstach z okresu renesansu,

tak zwany zwrot ku wnętrzu posiada interpersonalną, epistemologiczną motywację, zarówno w postaci wysiłków innych [postaci], by przeniknąć [wnętrze] Hamleta, jak i w potrzebie Hamleta, by poznać innych. Jego stwierdzenie: „To, co jest we mnie, nad postaci wzlata", stanowi jedną z wielu strategicznych autoreprezentacji w sztuce oraz specyficzną odpowiedź na ponaglenia ze strony Gertrudy i Klaudiusza, by zachowywał się tak, jak sobie tego życzą (16).

Według autorki The Interpersonal Idiom, w tym kontekście termin „podmiotowość" należy połączyć z „indywidualnym punktem widzenia oraz postawą w stosunku do świata" (16). Uznanie podmiotowości za coś więcej niż sposób samodoświadczania zmienia pojmowanie tego terminu z „niezależnego warunku bycia w interpersonalną strategię autoreprezentacji” ([podkreślenie autorki] 16). Przykładem subiektywnego podejścia może być każde działanie ukierunkowane na wykreowanie i podtrzymanie własnej perspektywy, która pomija lub wyklucza inne (16). W takim ujęciu problemu chodzi o działanie w stosunku do innych. Istotnym elementem tego podejścia jest „ja” w relacji z innymi, a więc „ja” postrzegane i postrzegające. Słownictwo z zakresu zmysłów stanowi nieodłączny element analiz renesansowych negocjacji pomiędzy wnętrzem a „zewnętrzem” człowieka. Tożsamość pojawia się bowiem w każdym akcie postrzegania, w każdej relacji percepcyjnej między osobami. Ustanowienie granic pomiędzy ",ja” a innym oraz wykreowanie swej podmiotowości to jedne z podstawowych wczesnonowożytnych kwestii badawczych z pogranicza różnych dziedzin.

Ponadto Selleck wnioskuje, że „[t]ożsamość nie jest dla Hamleta kwestią autokreacji, ale czymś, co wydarza się interpersonalnie", gdyż zgodnie z jej teorią „jesteśmy tym, czym stajemy się w trakcie każdego spotkania [z innym(i)]” (2008: 18). Ponadto uznaje ona, że „ja” w Hamlecie „to coś improwizowanego w kontekście innych" (18). Według badaczki Szekspir wykreował Hamleta, obdarzając go określoną strategią, którą bohater stosuje w sztuce. Przejmując kontrolę nad widocznymi i słyszalnymi przejawami 
wnętrza, jasno je manifestując w różnych zachowaniach, bohater „wciąż się wyreżyserowuje”, wielokrotnie "wystawia swe wnętrze” na spojrzenie innych, a nawet sam uczestniczy w procesie interpretacji różnych "pokazów” siebie (18). Jednocześnie jednak wydaje się świadomy swego stanu humoralnego i możliwości jego odgrywania przed innymi, więc również może umyślnie manipulować percepcją widzów/słuchaczy. Odkrywanie swojego wnętrza poprzez sterowaną i intencjonalną "grę pozorów" stanowi jeden z kluczowych elementów tej strategii. Hamlet staje się tym kimś, kto „wszystkie ścigał oczy" (3.1.184).

Jeśli przyjąć interpretację, że Szekspir sportretował Hamleta w taki sposób, by bohater ujawniał tylko tyle (ze swych zamiarów), na ile sam się zdecyduje (tym samym wciągając innych w „grę pozorów” celem odczytania tego, co znajduje się w ich „wnętrzach"), to strategia Hamleta okazuje się mylna. Nie tylko bowiem nie jest on w stanie przewidzieć reakcji otoczenia, ale przede wszystkim perfekcyjnie zmanipulować i przez to zawładnąć percepcją innych. Improwizowane „ja”, wchodząc w interpersonalne relacje, staje się przez nie kreowane. Zatem poza intencjami bohatera rozgrywa się jeszcze inny rodzaj przedstawienia - interakcja z innymi i ich punktami widzenia.

Meek z kolei sądzi, że Szekspir tak ukazał Hamleta, by dowieść, że „wszelkie sposoby zewnętrznego oznakowania są ostatecznie niesatysfakcjonujące” ([podkreślenie autora] 2009: 95). Fałsz i pozór kryją się bowiem pod pewnymi wyuczonymi zachowaniami, które stanowią element kodu wizualnego, jak na przykład „obfitość rzek płynących z oczu”. Znamienne, że znowu pojawia się w Hamlecie reprezentacja wzroku z bezpośrednim odwołaniem do organu percepcji wizualnej, i ponownie też służy on do interpretacji stanu wewnętrznego człowieka. Hamlet jednak krytykuje udawanie bólu i rozpaczy, które łatwo odegrać, przykładowo zalewając się łzami.

W ocenie McDermott postawa Hamleta kontrastuje z perspektywą Gertrudy, gdyż jej punkt widzenia zależy od percepcji wizualnej, na której opiera wydawanie sądów o rzeczywistości. Autorka pisze o „niebezpieczeństwach postrzegania wzrokowego”, na jakie narażona jest Gertruda, biorąc "pozory za to, co jest realne” („Perceiving Shakespeare”). Badaczka stwierdza nawet, że królowa „jest postacią najbardziej zainteresowaną zewnętrznymi pozorami i wizualnymi sygnałami” („Perceiving Shakespeare”). Taka reprezentacja zmysłu wzroku sprawia, że kobieca percepcja zostaje postawiona na niższej pozycji niż ta reprezentowana przez Hamleta. Książę nie tylko (w dalszej części dramatu) tropi wszelkie przejawy symulacji, opartej na zachowaniu i wyglądzie, ale również sam świadomie wkłada różne maski. Tym samym Szekspir pokazuje, że poleganie na zmyśle wzroku nie gwarantuje wiedzy prawdziwej, gdyż niejednokrotnie granica pomiędzy „byciem” a „zdawaniem się" okazuje się bardzo cienka. 


\title{
Sieć dworskich informatorów
}

By móc prowadzić „grę pozorów” oraz inwigilować pozostałych, Hamlet celowo podporządkowuje się i pozostaje na dworze elsynorskim. Spełnia tym samym prośbę Klaudiusza:

\author{
O ile idzie o wasz zamiar, aby \\ Do wittemberskiej wrócić akademii, \\ Sprzeciwia się on jak najbardziej naszym \\ Życzeniom i prosimy was, ustąpcie \\ I pozostańcie jako oczu naszych \\ Pociecha oraz radość, jako pierwszy \\ Dworzanin nasz, nasz krewny i nasz syn (1.2.345-352).
}

Kolejne odwołanie króla do organu wzroku może sugerować, że w jego hierarchii zmysłów wzrok stoi ponad innymi. Klaudiusz sygnalizuje, że obecność Hamleta na dworze zapewni mu dobre samopoczucie, głównie ze względu na możliwość obserwacji bratanka. Utrata Hamleta z oczu wiązałaby się z brakiem sposobności do bezpośredniego przyglądania się jego poczynaniom. Ponieważ Hamlet stanowi zagrożenie, jako kolejny kandydat do objęcia funkcji głowy państwa, najlepszym rozwiązaniem jest, by pozostał pod czujnym okiem panującego władcy oraz jego szpiegów. Klaudiusz tworzy sieć informatorów, którzy bazują głównie na najbardziej dystansującym zmyśle, jakim jest wzrok. Obserwacja pozbawiona śladów baczności i śledzenia jest, w zamyśle Klaudiusza, wstępem do indagowania Hamleta oraz wpłynięcia na jego organ słuchu.

Na swoich donosicieli, będących niejako „przedłużeniem jego oczu i uszu”, nowy król wybiera Rosencrantaza i Guildensterna. Zdaniem McDermott: „W swoich zamiarach uważnego szpiegowania, jednoczesnego patrzenia i słuchania Klaudiusz usiłuje rozszerzyć sferę fizycznych wpływów poprzez zaangażowanie [w nią] współdziałających ze sobą organów [wzroku i słuchu] jako szpiegów” („Perceiving Shakespeare”). Dawni przyjaciele Hamleta stają się „sensorycznymi informatorami” nowego władcy Danii („Perceiving Shakespeare”). Zostają nakłonieni przez Klaudiusza, który zwraca się do nich:

\footnotetext{
próbujcie wykryć,

Zbierając żniwo sposobności, czy też

Nie wpływa tak nań coś nam nie znanego,

Co ujawnione, będzie w naszej mocy

Uleczyć (2.2.155-159).
}

Król podpiera się argumentem, że Hamlet zmienił się nie do poznania, twierdząc, iż Rosencrantaza i Guildensterna na pewno doszły już słuchy, że 
książę jest „Ni z zewnątrz, ni na wewnątrz niepodobny / Do tego czym był wprzód" (2.2.145-146). Klaudiusz sygnalizuje, że wszelkie wizualne oznaki wskazują na transformację, przez jaką przechodzi jego bratanek. Zainicjowane przez podejrzliwego króla szpiegowanie nabiera charakteru anatomicznego badania oraz diagnozowania. Król podejrzewa, że jest w Hamlecie „coś obcego", co należałoby wykryć, zdemaskować i usunąć. Szekspir może tu dawać do zrozumienia, że choć przyczyna transformacji Hamleta nie jest na tym etapie dramatu stryjowi znana, to dostrzegalne przez oko Klaudiusza-anatoma zewnętrzne symptomy „niezdrowego wnętrza” - w sensie przenośnym - ostatecznie mają doprowadzić do dysekcji.

0 popularności zabiegów anatomicznych w kulturze renesansowej pisze Jonathan Sawday w The Body Emblazoned: Dissection and Human Body in Renaissance Culture (1995). Badacz posługuje się nawet określeniem „kultura dysekcji" (1995: viii), w której otwarcie ludzkiego ciała wiązało się z odkrywaniem i zdobywaniem wiedzy dotychczas niemalże niedostępnej. Anatom wczesnonowożytny bazował głownie na zmyśle wzroku, przez co poszukiwał wizualnych dowodów ukrytych w cielesnym wnętrzu. Pragnienie, by dotrzeć „pod powierzchnię” (ciała) innego człowieka, łączyło się z pragnieniem ustanowienia prawdziwej i niepodważalnej wiedzy na temat innych. Oko stało się organem, który miał zapewnić obiektywne poznanie. Warto tutaj zaakcentować, że wczesna nowożytność to okres liminalny, zawieszony pomiędzy przedkartezjańskim a kartezjańskiem pojmowaniem ciała, zmierzający ku odseparowaniu somy nie tylko od psyche, ale i od otoczenia, w jakim przebywa. Jak podaje Hillman: „Odgradzanie się [od innych] stwarza zapotrzebowanie na bardziej zgłębiające rodzaje wiedzy, które w zamian wywołują trwogę i pragnienie, by chronić granice ciała" (2007: 35).

W Hamlecie pojawia się motyw zafascynowania ludzkim wnętrzem, oscylujący wokół dwóch wspomnianych tendencji. Przy czym nie tylko Klaudiusz stosuje retorykę anatomiczną; retorykę, która „wielokrotnie daje do zrozumienia, że wiedza o wnętrzu ciała przekracza czysto fizyczną wiedzę o funkcjonowaniu wnętrza ciała” (Hillman, 2007: 33). W ocenie Hillmana: „Hamlet ustawicznie albo stoi po stronie, albo przeciwko koncepcji, że to, »co wewnątrz« $\iota^{5}$, jest »wewnątrz« w sensie cielesnym" (2007: 86). Z jednej strony Hamlet, choć sceptycznie, ale jednak deklaruje, że wnętrze ciała jest w pewien sposób połączone z prawdziwym „ja”, z drugiej zaś sugeruje, iż wnętrze i „zewnętrze” to dwa oddzielne królestwa. To ostatnie stanowisko skłania się ku nowożytnemu pojmowaniu podmiotowości Hamleta, gdzie istnieje wyraźne odseparowanie

„ja” i innego (bowiem nie wiadomo, co znajduje się w człowieku), cielesnego wnętrza i „zewnętrza” (gdyż to, co jest na zewnątrz, nie może reprezentować wnętrza), ciała

${ }^{5}$ Chodzi tu o wers „To, co jest we mnie, nad postaci wzlata” (1.2.314), który w wersji angielskiej brzmi: „But I have that within which passes show” (1.2.85). 
i odcieleśnionego wnętrza (jako że to, co jest wewnątrz, nad postaci wzlata, ponieważ jest niematerialne) (2007: 86).

Podobne rozterki, dotyczące związku pomiędzy granicami ludzkiego ciała a możliwością poznania wnętrza innych, zauważalne są także u Poloniusza, pierwszego sekretarza stanu i samozwańczego donosiciela nowego władcy. Stawiając diagnozę o stanie zdrowia mentalnego Hamleta, Poloniusz przede wszystkim bazuje na zmyśle słuchu.

Po wysłuchaniu relacji córki o spotkaniu z Hamletem uznaje, że jego powinnością jest odkrycie przed Klaudiuszem tego, co sam wykrył. Poloniusz dochodzi do wniosku, że przyczyna niepokojącego zachowania Hamleta nie może zostać przemilczana, w związku z czym przygotowuje własną wersję wydarzeń z wizyty Hamleta u Ofelii. W tym miejscu zacytuję fragment opisujący to zdarzenie z punktu widzenia Ofelii:

Gdy szyłam, panie w swej komnatce, nagle

Przede mną książę Hamlet - kapelusza

Na głowie nie ma, kaftan ma rozpięty,

Pończochy powalane, bez podwiązek,

Zwieszają się na kostkach jak łańcuszki

Kajdanów, twarz ma bladą jak koszula,

Kolana uderzają jedno w drugie,

A w oczach tak okropny wyraz, jakby,

Zwolniony z piekła, przyszedł opowiadać

O okropnościach (2.1.88-97).

Relacjonując odwiedziny Hamleta, Ofelia tworzy „brakującą [w sztuce], pozadramatyczną scenę, zawierającą niemą akcję" (Meek, 2009: 89). Dziewczyna jest jedynym milczącym świadkiem tego zdarzenia, dlatego też przede wszystkim polega na zmyśle wzroku. Zewnętrzny wygląd i zachowanie mężczyzny to podstawowe znaki wizualne, które odnotowuje. Meek zauważa, że opis Ofelii stanowi przykład zabiegu poetyckiego o nazwie enargeia. Szekspir wykorzystuje go w celu przywołania „żywego obrazu”, dzięki środkom werbalnym, oddającego szczegóły jakiegoś wydarzenia i detale opisujące osoby w nim uczestniczące (90).

Słowa mają wywołać u słuchacza takie wrażenie, jakby na bieżąco uczestniczył w zdarzenich. W dalszej części obrazowej i pełnej autentyczności narracji Ofelia kontynuuje opis sceny odbywającej się „poza sceną”:

Chwycił mnie za przegub ręki

I mocno trzymał, potem zaś się cofnął

Na długość ręki, drugą zaś trzymając

Na czole - tak - wpatrywał się w twarz moją, 
Jak gdyby chciał ją wyrysować. Długo
Tak stał, nareszcie, poruszając z lekka
Mą ręką i wstrząsając trzykroć głową
W górę i w dół, wydobył z piersi takie
Westchnienie boleściwe i głębokie,
Że mogło, jak mi się zdawało, wzruszyć
Z posad budowę całą jego ciała
I przerwać jego dni. Puszcza mnie potem
I z głową odwróconą wstecz na barkach,
Zdawało się, bez oczu szuka drogi,
Bo bez pomocy ich opuszcza pokój,
A blask ich we mnie wlepia do ostatka (2.1.100-115).

Powyższy obraz Hamleta to tylko fragment percepcyjnych wrażeń innych o bohaterze. Sugestywność tego cytatu polega na tym, że przypomina on zbliżenie i powiększenie postaci niczym bogate w szczegóły dzieło malarskie albo fotografia. O celowym eksperymentowaniu Szekspira z tą konwencją wspomina Meek (2009: 92). Badacz uwypukla także podobieństwo Hamleta do ducha. Podobnie jak zjawa milczy, choć wygląda, jakby chciał przemówić. Dodatkowo, w analogiczny sposób jak duch, „Hamlet jest nieobecny w sztuce, i musi być przywrócony [...] dzięki werbalnemu opisowi Ofelii” (92).

Hamlet oddziałuje zatem głównie na percepcję wizualną dziewczyny. Wywołuje u niej niepokój i niepewność co do przyczyn swojego „nienaturalnego” wyglądu. Brak standardowych językowych sygnałów werbalnych nie pozwala na skuteczną interpretację jego zachowania. Jedyny dźwięk, jaki towarzyszy spotkaniu, to „westchnienie boleściwe i głębokie”. Ofelia jest pozostawiona w komnacie bez żadnych wyjaśnień przez odchodzącego, niczym ślepiec, Hamleta. W swojej narracji odwołuje się ona do oczu, które zdają się wysyłać najistotniejsze sygnały wizualne. Kontakt wzrokowy dwóch milczących postaci stanowi w trakcie tego spotkania podstawę komunikacji. Bohaterka wydaje się traktować wizytę mężczyzny bardzo poważnie. Jego wpatrywanie się w nią odczytuje tak, jakby Hamlet tworzył własny obraz dziewczyny, zapamiętując jej twarz, aby móc portretować ją oczami wyobraźni. Zdaniem Thorne, Szekspir wykorzystał w tym miejscu „konwencjonalny leksykon wizualny z zakresu melancholii miłosnej" (2000: 119), po to, by bohater bezpośrednio zmanipulował zmysły Ofelii, a następnie innych postaci dramatu. Jak się okaże w kolejnej scenie, przekaz Poloniusza będzie już narracją narracji, zaświadczającą o skuteczności percepcyjnego dezorientowania innych przez Hamleta.

Poloniusz postanawia odkryć przed Klaudiuszem i Gertrudą „swoją prawdę" o Hamlecie i ujawnić jego listowną korespondencję z Ofelią. Zostaje więc wykreowany na detektywa, który przedstawia „dowody” mające zaświadczyć o obłąkaniu Hamleta, odczytując na głos wyznania kierowane przez księcia do jego córki. Kanclerz wyraźnie pragnie oddziaływać na słuch króla i królo- 
wej, by trwale zaskarbić sobie ich przychylność i zaufanie. Wspomina o relacji córki z niepokojącej wizyty Hamleta w jej komnacie i przekazaniu przez nią listów na jego ręce:

To mi posłuszna pokazała córka,

Ponadto uchu memu powierzyła

Zaloty jego, wiernie mi podając

Okoliczności wszystkie, czas i miejsce (2.2.288-292).

Powyższy cytat pokazuje, że „nadworny detektyw” podkreśla znaczenie zmysłu słuchu i poleganie na nim w jego „działalności wywiadowczej”. Istotne jest, że Szekspir tak sportretował Poloniusza, by ten, nie mając naocznego potwierdzenia swoich przypuszczeń, traktował je jako niezaprzeczalne dowody w sprawie. W dalszej części swojego wywodu Poloniusz odwołuje się do określeń związanych ze zmysłami, a w szczególności do słownictwa wizualnego, sprawiając wrażenie, jakby sam zaobserwował elementy flirtu:

Cóż pomyślelibyście, że uczynię,

Gdym ujrzał miłość tę rozwijającą

Do lotu skrzydła!

A muszę wam powiedzieć, żem spostrzegł,

Nim córka mi doniosła. I cóż byście

Myśleli wy i najjaśniejsza pani,

Tak dla mnie droga, gdybym był się bawił

W szufladkę lub notatnik, czy też może

Zawiqzał oczy sercu, by być głuchym

I niemym, czy też patrzył na tę miłość,

Poza patrzeniem nic nie przedsiębiorąc? (2.2.296-307).

Następnie Poloniusz sugestywnie kreśli portret Hamleta jako nieszczęśliwie zakochanego mężczyzny, którego względy zostały odrzucone przez Ofelię (za ojcowską namową oraz zgodnie z jego nakazem). Pragnąc pozostać głównym śledczym w sprawie, Poloniusz oznajmia: „Wyszukam skrytą prawdę, choćby nawet / I w samym środku ziemi była skryta" (2.2.328-329). Ostatecznie staje się on pomysłodawcą intrygi, polegającej na zaaranżowaniu przypadkowego spotkania Hamleta i Ofelii, w trakcie której para ma być obserwowana i podsłuchiwana. Proponuje więc Klaudiuszowi: „A wy staniecie ze mną za obiciem; / Możecie obserwować to spotkanie" (2.2.334-335). Spodziewając się potwierdzenia swojej diagnozy w sprawie stanu zdrowia Hamleta, Poloniusz nie dopuszcza do siebie innego rozwiązania. Niepoinformowany o pojawieniu się ducha na zamku, nie wie o kluczowym dla zachowania księcia spotkaniu ze zjawą. Szekspir zastosował w tej scenie strategię snucia przypuszczeń w oparciu o reprezentacje doświadczeń zmysłowych. 


\title{
„Czyliś jest zbawionym duchem, / Czy potępieńca zjawa, czy owiany / Niebiańska wonią, czy piekielnym wichrem" (1.4.730-732)?
}

O ile Klaudiusz i Poloniusz posiadają własnych, mniej lub bardziej mimowolnych i skutecznych informatorów, o tyle Hamlet wydaje się mieć zupełnie nieprzypadkowe i bardziej efektywnie działające, dodatkowe oczy i uszy. Skoro kultura renesansu to kultura rozdarta (w znaczeniu metaforycznym) między okiem a uchem, to współdziałanie wiedzy, opartej na percepcji wizualnej z informacjami, przetwarzanymi przez percepcję audialną, powinno dawać pełniejszy obraz sytuacji. Szekspir wprowadza wątek, w którym Horacjo, w towarzystwie Marcellusa i Bernarda, przybywa z zaskakującymi dla Hamleta wieściami o pojawieniu się ducha. Horacjo inicjuje opowieść o zaobserwowanym spektaklu milczącego ducha, która, zdaniem Kelleya, stanowi kolejną stylizowaną narrację (1999: 92):

\author{
Dwukrotnie noc po nocy ci panowie, \\ Marcellus i Bernardo, o godzinie \\ Dwunastej pełniąc straż wśród głuchej pustki \\ I ciszy, taką napotkali zjawę: \\ Postać, podobną do waszego ojca, \\ W zbroi od stóp do głów przed ich oczyma \\ Staje i wolnym, uroczystym krokiem \\ Wspaniale mija ich. Przechodzi trzykroć, \\ O długość swej buławy od ich oczu \\ Zmąconych nagła trwoga, osłupiałych, \\ Gdy oni, strachu mrozem w galaretę \\ Prawie zmienieni, stoją oniemiali, \\ Nic doń nie mówiąc. Z tajemniczą grozą \\ Zwierzają się przede mną, co widzieli, \\ I trzeciej nocy ja straż trzymam z nimi, \\ A tam zupełnie zgodnie $\mathrm{z}$ ich relacją, \\ Stwierdzając, każde słowo co do czasu \\ I kształtu, widmo jawi się. Ja znałem \\ Waszego ojca - mniejsze podobieństwo \\ Jest między jedną tą a druga ręką (1.2.443-462).
}

Horacjo konstruuje opowieść precyzyjnie i fachowo, jednak jej celem nie jest zmanipulowanie Hamleta. Jego przekaz, podobnie jak przekaz Ofelii, jest autentyczny i w żaden sposób niezafałszowany. Obie narracje łączy malarska dbałość o szczegóły i łatwość „przemówienia” do oczu i uszu księcia.

Snujący opowieść Horacjo podkreśla napięcie i zamieszanie, które wywołała zjawa, między innymi opisując „oczy zmącone nagłą trwogą”. Jego opowieść, jak podaje Kelley, 
rozwija się z narracji trzecioosobowej na temat relacjonowanych zdarzeń („zwierzają się przede mną, co widzieli") w osobiste doświadczenie (na przykład narracja w pierwszej osobie) dotyczące spotkania Horacja z duchem. Owa zmiana odpowiada metamorfozie Horacja ze sceptyka w człowieka wierzącego, i służy także jako strategiczna technika narracyjna, mająca przekonać Hamleta o prawdziwości historii (93).

Scena ta ma rozbudować warstwę dialogową. Osłupiały opowieścią Hamlet analizuje przekaz Horacja, zasypując go wieloma dodatkowymi pytaniami dotyczącymi wyglądu ducha: „Więc w zbroi?” (1.2.478), „I od stóp do głów?” (1.2.480), „Był blady czy czerwony? (1.2.484), „I wzrok w was wlepiał?” (1.2.482). Zadawanie pytań wymusza otrzymywanie odpowiedzi i utwierdza Hamleta w konieczności skonfrontowania tego, co usłyszał, z własnym doświadczeniem wzrokowym. Zostaje on zatem wciągnięty w „krąg wtajemniczonych” w opowieść z elementami legendy. Zastrzega jednak, by nikt nie zdradził historii o duchu, co może świadczyć o tym, że „Hamlet rozumie, że wiedza to władza” (95).

Zatrzymanie dotychczasowej wiedzy w tajemnicy ma dopomóc w dogłębnym zbadaniu sprawy i zdobyciu kolejnych informacji, spośród których tylko te strategiczne będą mogły być wyjawione „uszom niewtajemniczonych”. Siłę oddziaływania opowieści potwierdza ostateczna refleksja Hamleta:

Duch ojca w zbroi! Święci się coś złego

I czarne mi majaczą podejrzenia.

Gdybyż już była noc! Do tego czasu

Ukój się, duszo ma. Ohydne czyny,

Chociaż je cały ziemski glob przytłoczy,

Wbrew temu muszq wyjść na ludzkie oczy (1.2.510-515).

Wymowne staje się w cytowanym fragmencie odwołanie do organu wzroku. Kolejna reprezentacja ukazuje demaskatorski potencjał wzroku, który jednocześnie posiada moc odkrywania „ohydnych czynów” oraz przekonywania innych o prawdziwości ludzkich poczynań. Być może jest to zapowiedź strategii stopniowego odsłaniania szokujących prawd, którą Szekspir posłuży się w kolejnych scenach sztuki, a może bezpośrednia aluzja do mającego się rozegrać na oczach wszystkich prywatnego śledztwa Hamleta, którego kluczowym momentem będzie wystawienie „Pułapki na myszy”.

Analiza tej sceny wskazuje na to, że oczekiwane spotkane z duchem jest przede wszystkim wyzwaniem dla zmysłów Hamleta. 0 pojawieniu się zjawy informuje Horacjo: „O panie, patrzcie, patrzcie, idzie widmo!” (1.4.728), lecz to Hamlet natychmiastowo przemawia do ducha i między innymi tak tłumaczy swoje zachowanie:

Przybywasz tu w postaci tak dalece

Kuszącej do rozmowy, że ja muszę

Do ciebie mówić. Nazwę cię Hamletem, 
Monarchą, ojcem, władcą tego kraju,

A ty mi odpowiedź daj! (1.4.734-737).

Początkowo zjawa przyjmuje taktykę milczenia, wskazując gestami na Hamleta jako jedyną postać, do której przemówi. Chcąc odseparować go od towarzyszy, duch prowadzi księcia w ustronne miejsce, podkreślając tym samym, że to, co ma do przekazania, przeznaczone jest tylko dla ,jednej pary uszu". Następuje swego rodzaju wyznaczenie słuchacza. Zdaniem autora "Narratives, Narrators and Narratees in Hamlet", rozmowa z duchem jest przykładem na to, jak napięta sytuacja implikuje efekt narracyjny (1984: 34). Pierwsze słowa, które duch kieruje do Hamleta, brzmią niczym nawołanie do uważnego słuchania: „Bacz na me słowa” (1.5.790). Pierwsza reakcja Hamleta, który zamiast uciekać - oczekuje opowieści, świadczy o sile oddziaływania ducha na organ słuchu księcia. Potwierdzeniem jest słowo: „Baczę” (1.5.791). Moment ten jest szczególnie istotny zarówno dla nakazującego wysłuchanie narratora (duch), jak i otwartego na narrację słuchacza (Hamlet). Wrażenie wizualne, jakie duch powoduje w Hamlecie, potwierdza on wrażeniem audialnym, wydając polecenie synowi: „W powadze / Wysłuchaj tego, co ci tu odkryję" (1.5.796-797).

W opinii Kelleya duch zaczyna przedstawiać swoją historię w podobny sposób, jak czynią to narratorzy legend (1999: 96). Jednak duch-narrator od razu ostrzega o wyjątkowym przesłaniu swojego opowiadania, zobowiązującym słuchacza do pomszczenia go. W samym słowie „pomścić” zawiera się groza opowieści. Zjawa informuje, że tylko zakaz, by: „Więzienia swego zdradzać tajemnice" (1.5.806), powstrzymuje ją od ujawnienia szczegółów dotyczących miejsca, w którym przebywa, czyli zaświatów. O porażającej sile takiej opowieści świadczy jego ostrzeżenie:

rozsnułbym przed tobą powieść, Której najmniejsze słowo spustoszenie Sprawiłoby w twej duszy, oczy twoje, Jak gwiazdy, grozq wytrąciło z orbit, Twe zaplecione, utrefione pukle Porozdzierało, ażby każdy włosek Stanął ci dębem ni to kolce jeża Rozgniewanego; lecz nie lza przed uchem Z ciała i krwi rozgłaszać rzeczy wieczne (1.5.807-815).

Cytowane odniesienia do takich organów, jak oczy i uszy, wyłaniają następne literackie reprezentacje percepcji wizualnej i audialnej w Hamlecie. Szekspir może sygnalizować w tym miejscu, że ludzkie ucho mogłoby nie przyswoić opowieści wykraczającej poza obrazowanie ziemskich zdarzeń. Wpływ takiej wiedzy na człowieka mógłby mieć także negatywny skutek 
w postaci „wytrącenia oczu z orbit”. Taka reakcja zewnętrzna miała pokazać, jak silnie opowieść oddziałuje na ludzką duszę, a ta z kolei, mając połączenie z organami sensorycznymi, może przez nie manifestować wewnętrzny stan emocjonalny. Zjawa daje do zrozumienia, że oszczędzi Hamletowi „pomieszania zmysłów", choć i tak jej narracja stanowi badanie granic wytrzymałości percepcyjnej księcia.

Najistotniejszy fragment opowieści dotyczy odkrycia prawdy na temat okoliczności śmierci dawnego króla. Postać rozwijającego opowieść ducha została tak wykreowana przez Szekspira, by punkt kulminacyjny jego narracji zaczął sterować akcją dramatu, mimo że widmo pojawia się w sztuce jeszcze zaledwie jeden raz. Zjawa dementuje, by rozgłaszane wieści o ukąszeniu przez węża śpiącego w sadzie króla, były faktyczne:
Posłuchaj mnie, Hamlecie: rozgłaszają,
Że mnie ukąsił wąż, śpiącego w sadzie.
Tak to sromotnie oszukano uszy
Całego kraju; lecz ty wiedz, szlachetny
Młodzieńcze, że ten wąż, którego żądło
Twojemu ojcu odebrało życie,
Koronę jego teraz ma na głowie (1.5.830-836).

Obrazowo kreując nowy scenariusz zdarzenia, zjawa odsłania zakłamanie Klaudiusza. Zatem uszy Hamleta zostają „nakarmione” zupełnie inną historią, która ma całkowicie podważyć autorytet stryja. Duch przedstawia taką przejmującą wizję:

Gdy spałem w sadzie poobiednim swoim

Zwyczajem, stryj twój zaszedł mnie w godzinie

Nieostrożności, przeklętego cisu

Sok niosąc w kubku, i wlał w mego ucha

Przedsionek jadowity wywar, który

Z krwią ludzką żyje w takiej nieprzyjaźni,

Że chyżo, ni to żywe srebro, bieży

Przez wszystkie ciała furtki i uliczki,

Ścinając nagle z niewstrzymaną siłą,

Jak kropla kwasu, gdy ją wpuszczą w mleko,

Cienką i zdrową krew (1.5.857-867).

Autor artykułu „Hearing in Hamlet: Poisoned Ears and the Psychopathology of Flawed Audition", Peter Cummings, uważa, że ze względu na liczne odwołania do zmysłu słuchu, w tym fundamentalne dla sztuki odniesienie do zainfekowanych uszu, Hamlet może być potraktowany jako „nowatorski renesansowy tekst", poruszający zagadnienia audialne od strony anatomii, 
fizjologii, dysfunkcji oraz dosłownego i metaforycznego zatrucia (1990: 83). Badacz uważa, że być może na fascynację Szekspira związaną ze zmysłem słuchu częściowo wpłynęły odkrycia anatomiczne Bartolomea Eustachiusza z 1564 roku. Przypuszczalnie jego szczegółowe badania, odnoszące się do budowy ucha (trąbka Eustachiusza), stały się inspiracją do wprowadzenia wątku wpuszczenia trucizny poprzez organ słuchu (84).

Podatność na słowa, jakie duch kieruje do Hamleta, który uważa go za zmarłego ojca, i w dodatku uznaje jego ojcowski autorytet, ma więc aspekt osobisty. Słuchanie ustanawia w analizowanej scenie relację podległości wobec narratora. 0 związku między słuchaniem i okazywaniem w ten sposób posłuszeństwa pisze Reina Green w „Poisoned Ears and Parental Advice in Hamlet". Jedna z kulturowych wartości renesansu, przypisywanych postrzeganiu słuchowemu, sprowadzała się do tego, że dzieci miały słuchać z uwagą swoich rodziców i spełniać ich zalecenia. W Hamlecie duch zmarłego ojca nakazuje pomszczenie swojej śmierci. Hamlet dowiaduje się o tym bezpośrednio od zjawy, co powoduje, że proces słuchania wywołuje nieodwracalne zmiany percepcyjne u mężczyzny. Po wysłuchaniu ojca, wszelkie dotychczasowe zdarzenia nabierają innego sensu dla księcia. Jego postrzeganie, z jednej strony, zostaje „rozjaśnione”, z drugiej zaś - przytłoczone wizją pomszczenia ojca. Według Roberta R. Wilsona:

Bezpośredni odbiorca opowieści ducha (Hamlet) wierzy w nią, ale później znajduje powód, by [w nią] zwątpić. To również wydaje się stanowić komentarz do natury opowieści. Jej wpływ może być ogromny, może nasycić ucho i porwać audytorium, lecz potem, po ochłonięciu, mogą pojawić się wątpliwości. Ponieważ narracja daje powód do zwątpienia, musi (w Hamlecie) być poddana testowi. To napędza powracającą konwencję odtwarzania opowiadań, która przewija się w sztuce jako: pantomima; „Pułapka na myszy”; opowieść, co do której Hamlet twierdzi, że przekazał ją Horacjowi, lecz która nie jest opowiedziana w sztuce; historia, którą Horacjo w końcu opowie, lecz nie dzieje się tak w toku rozwoju sztuki; czy też wersja podsumowująca, którą Horacjo w rzeczywistości opowiada (1984: 35-36).

\section{Z kolei opisując postać ducha-narratora, R. Radon Wilson zauważa, że:}

Duch w Hamlecie, jako główny narrator, charakteryzuje się wyrafinowaną umiejętnością przewidywania (zawieszenie, szok, antycypacja), a szczególnie - wypracowaną przebiegłością w zdobywaniu uwagi słuchaczy, w tym Hamleta. Osiąga to [zainteresowanie], dzięki rozwodzeniu się nad dziwami opowieści, których nie może zdradzić. Każdy aspekt stylu opowiadania podkreśla charakter narratora, zaś jego głos w chwili opowiadania jest przepełniony wiedzą i odznacza się wprawą (1995: 60).

Szekspir wykreował ducha na znakomitego narratora, którego historia całkowicie odmienia postrzeganie wydarzeń przez Hamleta, i powoduje, że zaczyna on manipulować postrzeganiem zmysłowym innych mieszkańców dworu. Zjawienie się ducha może być potraktowane jako odpowiedź na szczególną 
potrzebę rozwikłania niejasności piętrzących się na dworze elsynorskim. Jest to przykład historii wprowadzającej Hamleta w szczegóły wydarzeń jeszcze sprzed śmierci jego ojca. Bohater poznaje historię, która - jak wynika z opowieści ducha - przytrafiła się naprawdę. Opowieść rozgłoszona w postaci wersji oficjalnej (wymyślona przez Klaudiusza) musi zostać okrężną drogą zdementowana, bo w rzeczywistości jest zniesławieniem zmarłego króla.

W pracy Shakespeare's Noise Kenneth Gross podejmuje problematykę wczesnonowożytnej kulturowej obsesji dotyczącej zniesławienia i spotwarzenia poprzez plotkę, znajdującej swoje literackie oblicze w sztukach Szekspira. Autor skupia się na niespokojnych, silnie oddziałujących na słuch, czy też wręcz niebezpiecznych formach wypowiedzi, takich jak: plotka, pogłoska, zniesławienie, oszczerstwo, obelga, złorzeczenie, przeklinanie i klątwa. Eksponuje „przemoc, jakiej ludzka mowa dopuszcza się wobec ludzkich uszu” (2001: 1) oraz bada "niezrozumiałą dostępność samego organu słuchu” (1). Gross wykazuje, że sztuki Szekspirowskie, w tym Hamlet, „są opanowane przez przebiegłą siłę szkalujących słów oraz przez zmienną postać oszczerców" (2)

Badacz utrzymuje, że poprzez „odtajniającą” opowieść ducha Szekspir podkreśla w Hamlecie moc oddziaływania słowa na ludzki organ słuchu i wynikającą z tego „siłę zniesławienia” (2001: 26). Historia ducha pokazuje, że w opowieści o zatruciu króla słowami (zniesławieniu) również tkwi trucizna werbalna, która przenika do uszu słuchacza (Hamleta) (28). Relacja z otrucia śpiącego króla przez wlanie mu trującej cieczy do ucha i z jego natychmiastowej, deformującej ciało śmierci, przypomina proces rozprzestrzeniania się pogłoski z niekontrolowaną szybkością. W dodatku szkodliwość plotki ma podobne właściwości, co toksyczność trucizny, dlatego bez trudu podano wiadomość o ukąszeniu króla przez węża, a zatajono prawdziwą przyczynę, o której wie jedynie Klaudiusz-morderca.

Z kolei McDermott zwraca uwagę na fakt, że duch poniekąd zachęca Hamleta do wyostrzenia zmysłów. Historia śmierci jego ojca ma ostrzec księcia przed tym, jak podatne na uszkodzenie może być ucho, zwłaszcza jeśli, będąc „niestrzeżone”, stanie się „otwartym celem ataku” („Perceiving Shakespeare"). Nie tylko moment śmierci dawnego króla stanowi przestrogę. Także osłabienie uwagi wizualnej i słuchowej jeszcze za życia władcy mogło skutkować uleganiem pozorom zachowań i wypowiedzi Klaudiusza. Badaczka akcentuje koncentrację uwagi jako warunek pełnego zaangażowania zmysłów w postrzeganie („Perceiving Shakespeare”).

„Zainfekowany” nowymi wieściami Hamlet powraca do swoich towarzyszy, lecz nie zdradza treści rozmowy. Nakazuje im także, by nie wyjawili swo-

\footnotetext{
${ }^{6}$ Mechanizmem działania plotki i pogłoski w renesansowej kulturze zajmuje się Keith M. Botelho w Renaissance Earwitness. Rumor and Early Modern Masculinity (2009). Badacza interesuje problematyka wpływu i rozprzestrzeniania się plotki w zmaskulinizowanej kulturze tamtego okresu.
} 
ich doświadczeń wizualnych, po to, by ich relacje nie rozprzestrzeniły się, przypuszczalnie nabierając charakteru plotki lub pogłoski. Potwierdzenia przysięgi domaga się też głos z podziemia - głos ducha, który jest już całkowicie bezcielesnym dźwiękiem. Co ciekawe - duch, który przybywa jako zjawisko wizualne, odchodzi jako zjawisko audialne. Jednocześnie Hamlet zapowiada, że strategia, jaką zamierza przyjąć (po spotkaniu z duchem), będzie miała nieoczekiwany przebieg. Dlatego ostrzega, że może zachowywać się w sposób dziwny i niezwyczajny, co będzie spowodowane przyjęciem na siebie „zewnętrznego straszydła pozoru” (1.5.985-986). Książę uprzedza, że jego dotychczasowe postrzeganie uległo zmianie, stąd jego autopercepcja oraz percepcja innych będą odmienne od wcześniejszych. Do pewnego stopnia Hamlet pragnie wywołać „szok percepcyjny” u niektórych mieszkańców dworu, z pominięciem swoich najbliższych towarzyszy.

\section{Wątki szpiegowskie - śledzony Hamlet w roli śledczego}

Pierwszą sytuacją, w której Hamlet może „założyć” jedną z masek, umożliwiających odgrywanie siebie jako kogoś innego, jest spotkanie ze szpiegami Klaudiusza: najpierw z Poloniuszem, a następnie z Rosencrantzem i Guildensternem. Thorne uważa, że inspiracją do przybrania „zewnętrznego straszydła pozoru" jest sposób, w jaki duch wystąpił przed Hamletem. Chodzi tu o jego teatralny styl bycia i prowadzenie "gry opartej na zaciemnianiu i ujawianiu" (2000: 118) informacji (ale także analogicznie - pojawianiu się i znikaniu samego ducha). Zdaniem badaczki, syn zamierza naśladować ojca, i podobnie jak on - skłonić innych do spojrzenia na daną kwestię z jego perspektywy (119). Jednocześnie wcielanie się w rolę aktora pozwala Hamletowi na realizację własnego „rozdartego »ja«”. Ta dramatyczna konwencja, zastosowana przez Szekspira, odsłania również wczesnonowożytne rozterki, mające związek z prawdziwością bądź mistyfikacją w relacjach społecznych.

Po uknuciu intrygi, polegającej na podstawieniu Hamletowi córki Poloniusza jako przynęty, ten ostatni nawiązuje rozmowę z przechadzającym się po zamku księciem. Dialog między mężczyznami przebiega według narzuconej przez Hamleta gry słownej, co do której reguł pozostaje świadomy tylko sam pomysłodawca. Hamlet kpi i drwi z Poloniusza, ten zaś przypisuje jego dziwne zachowanie szaleństwu, komentując: „Jak trafne są czasem jego odpowiedzi! Szaleństwu udają się niekiedy takie szczęśliwe wyrażenia, jakich by nie urodziły równie pomyślnie mądrość i zdrowie" (2.2.391-393). Hamlet stosuje „metodę w szaleństwie”, opartą na posługiwaniu się błazeńskim językiem i humorem klowna (Gross, 2001: 12). Cięte i prześmiewcze riposty skrywają „zainfekowane prawdą” wnętrze Hamleta. Bohater atakuje swoich rozmówców z różną mocą i różnymi „ostrymi narzędziami” językowymi. Może 
to być takie nadużycie słowa, jak: „silnie żrąca sieć kalamburów i dowcipów, labirynt urywkowych opowieści i alegorii, utyskiwania, zniekształcone pogłosy i aluzje, natrętne i zaraźliwe insynuacje" (11). Hamlet, intencjonalnie, za każdym razem kieruje do właściwego słuchacza odpowiedni instrument językowy, oddziałujący na percepcję audialną.

Dodatkowe rozdrażnienie księcia powoduje odkrycie kolejnego zakłamania, tym razem dotyczącego jego towarzyszy zabaw, nasłanych przez Klaudiusza i mających, podobnie jak Poloniusz, wysondować przyczynę odmiany Hamleta. W trakcie rozmowy publicznie demaskuje on królewskich donosicieli, dla siebie zaś zachowuje spostrzeżenie: „Chyba muszę was mieć na oku”. Ta kolejna reprezentacja organu wzroku pokazuje, że Szekspir jawnie kreuje Hamleta na śledczego-obserwatora. Z jednej więc strony książę staje się mistrzem retoryki, mającej na celu „wzięcie w posiadanie” ucha słuchacza, z drugiej zaś - jest wszechobejmującym swym spojrzeniem obserwatorem. W opinii Dona Parry Norforda, autora artykułu „»Very Like a Whale«: The Problem of Knowledge in Hamlet”, to jednak „ucho bardziej niż oko stanowi organ wiedzy" w dramacie (1979: 567). Badacz stoi na stanowisku, że organ wzrokowy nie dorównuje organowi słuchowemu, jeśli chodzi o dostarczanie informacji o świecie, bo dopiero ten ostatni wychwytuje esencję treści. Ową esencją nie jest jednak statyczna rzeczywistość, lecz stawanie się (560-561). Nie mając bezpośredniego dostępu do duszy ani możliwości dogłębnego wpłynięcia na człowieka, oko unieruchamia obserwowane obiekty i dystansuje od nich (obserwatora) (565). Norford podchodzi do słuchu i wzroku antytetycznie, twierdząc, że to, co audialne, jest „aktywne, dynamiczne, penetrujące”, a to, co jest wzrokowe - „bierne, statyczne, bez głębi” (565). Pomimo zafascynowania Hamleta tym, co zewnętrzne i widoczne dla oczu, zdaniem autora artykułu, to, co werbalne, może być ważniejsze w trakcie poszukiwań prawdy i znaczenia (563).

Ostatecznie Rosencrantz i Guildenstern wyznają Hamletowi „prawdę”: „Mości książę, posłano po nas” (2.2.480), i zapowiadają przybycie na zamek grupy aktorów. Dramaturg wprowadzając ten wątek, stwarza okazję, by Hamlet dokładnie przeanalizował pod względem percepcyjnym grę aktorską profesjonalnych aktorów, i korzystając z tej nauki, użył nowych metod i technik wpływu na postrzeganie widzów i słuchaczy, czyli mieszkańców dworu. Doceniając kunszt, z jakim aktorzy potrafią odegrać rzeczywiste zachowania i emocje, Hamlet entuzjastycznie zachęca pierwszego aktora do odtworzenia tego fragmentu sztuki, który miał on znać już ze słyszenia. Książę odwołuje się do wrażeń audialnych, które wywołała w nim recytacja aktora dotycząca śmierci króla Priama: „Słyszałem był raz, jak deklamowałeś pewien ustęp” (2.2.642-643) oraz „Posłuchajmy zaraz tyrady. Dalej, dajcie nam próbkę swojej sztuki! / No, patetyczną tyradę" (2.2.637-640). Pierwsza próba gry aktorskiej, zainicjowana przez Hamleta początkowymi wersami fragmentu sztuki, 
jest próbą głosu i słuchu oraz przetestowania własnej reakcji na deklamację prawdziwego aktora. Fragment zabójstwa Priama przez Pirrusa jest wyjątkowo okrutny, malujący w makabrycznych szczegółach walkę między królem Troi i mszczącym się synem Achillesa. Meek akcentuje wizualny wymiar tej opowieści (2009: 99).

W części, którą wygłasza Hamlet, pojawia się reprezentacja organu wzroku: „Z oczyma niby karbunkuły, szuka / Piekielny Pirrus wszędzie sędziwego / Dziada Priama (2.2.675-676). Barbarzyńskość i szał bojowy podkreśla czerwony (piekielny) kolor oczu wyeksponowany (w przytoczonym wersie) przez Szekspira. Porównanie oczu z karbunkułami może też symbolizować pragnienie zemsty, jakim pała Pirrus. W dalszym fragmencie zaś Szekspir obrazuje postrzeganie słuchowe przez bezpośrednie odwołanie do uszu:

Naciera Pirrus, lecz, wściekłością ślepy,
Nie trafia; jednakże sam świst i wiatr
Strasznego cięcia wali osłabłego
Priama o ziem, a w tej chwili Ilium,
Choć pozbawione zmysłów, jakby czuło
Ten cios, pochyla gorejące szczyty
Do fundamentów i ohydnym trzaskiem
W niewolę bierze ucho Pirrusowe,
Bo oto jego oręż, co już z góry
Opuszczał się na mleczną czcigodnego
Priama głowę, rzec by można, utkwił
W powietrzu i niczego nie dokonał (2.2.686-697).

Powyższy fragment recytuje pierwszy aktor, zaś Hamlet definitywnie wycofuje się z deklamowania, jakby celowo chciał uniknąć wygłoszenia tyrady opowiadającej o tym, jak syn wymierza zemstę za śmierć ojca.

Wybrany fragment ma charakter narracyjny o podniosłej i tragicznej tematyce. Podobieństwo do historii Hamleta jest znane tylko jemu samemu. Kelley wspomina, że zarówno Hamlet, jak i Pirrus, posiadają motyw do zemsty, a także, że obaj przeżywają zastygnięcie w działaniu (1999: 97). Pirrus zastyga z mieczem w dłoni, ale siła jego ciosu powala na ziemię Priama. Jednocześnie z odgłosem upadku króla daje się słyszeć przeraźliwy huk walących się murów Troi. 0 jeszcze innym przejmującym dźwięku mowa jest w kolejnym fragmencie sceny. Jest to szloch i krzyk Hekuby, małżonki Priama, która widząc,

Jak Pirrus bawił się złośliwie, członki Małżonka jej siekając, krzyk straszliwy, W jaki natychmiast uderzyła, byłby Chyba, że ziemskie sprawy nie są zdolne 
W ogóle wzruszyć bogów - łzy wycisnął

Z płomiennych oczu niebian i namiętną

W nich wzbudził boleść (2.2.738-743).

Szekspir, przy pomocy Hamleta, analizuje grę aktorską i zastanawia się nad zmianami w wyglądzie samego aktora, a także nad możliwą reakcją percepcyjną odbiorców sztuki. Książę podziwia więc wzruszenie, jakie ogarnęło pierwszego aktora, gdy deklamował fragment o Hekubie. Artysta tak przeżywał własną recytację, że „w oczach stanęły [mu] łzy” (2.2.779). Dostrzega to także obecny w trakcie deklamacji Poloniusz, który tuż po wygłoszeniu mowy aktorskiej sugeruje: „Proszę popatrzyć, czy nie pobladł i nie ma łez / w oczach" (2.2.744-745).

Motyw „łez w oczach” pojawia się już kolejny raz w sztuce, zatem Szekspir nie przez przypadek posługuje się tym wyobrażeniem. Będąc zewnętrzną formą ekspresji smutku, bólu i żałoby, zapłakane oczy mogą wyrażać prawdziwe bądź udawane emocje. Skoro aktor potrafi wyzwolić w sobie „fikcyjne" emocje, porównywalne pod względem wizualnym z realnymi odczuciami cierpiącej osoby, to wszystko, co manifestowane, może być pozorne. Szekspir wydobywa kontrast pomiędzy teatralnością tego gestu a manifestacją przeżyć wewnętrznych, które okazują się zbyteczne. Jest to kolejny przykład na ukazanie fundamentalnej różnicy - niedającej się wykryć "gołym okiem” - między tym, co jest, a tym, co wydaje się być. W Hamlecie jego autor wskazuje na paradoksalność motywu „zalewania się łzami” jako wizualnego przejawu życia wewnętrznego, który może być zarówno upozorowany, jak i autentyczny, a mimo to budzący podejrzenia co do swojej prawdziwości.

Kluczowa wydaje się w dramacie Szekspira relacja pomiędzy odgrywaniem/spektaklem a prawdą. Jedno z wyobrażeń prawdy w kulturze renesansowej ujmowało ją jako niewidzialną i skrywającą się we wnętrzu - zewnętrznie nie do wykrycia. Wewnętrzność, niedostępność i niewidoczność znajdowała się na drugim biegunie oraz jako przeciwieństwo w stosunku do zewnętrzności, dostępności i widoczności, czyli tego, co uchwytne za pomocą zmysłów. Autentyczność kryła się we wnętrzu, zaś to, co odgrywane, wiązało się z zewnętrznością. W książce Inwardness and Theater in the English Renaissance (1995) Katherine Eisaman Maus porusza problematykę ludzkiego wnętrza oraz „zewnętrza” w kontekście renesansowej konceptualizacji „ja”. Duchowe i cielesne przejawy istnienia oscylują wokół tematyki autentyczności (prawdy), uchwytności (materialności) oraz poznawalności (wiedzy) jednostki ludzkiej. Podkreślając znaczenie wczesnonowożytnej debaty na temat psychicznych oraz fizycznych wymiarów ,ja”, Eisaman Maus zwraca uwagę na wszechobecność zagadnienia podmiotowości w filozoficznych, medycznych, religijnych oraz literackich tekstach tego okresu. Życie mentalno-duchowe człowieka stanowiło wręcz obsesyjnie eksploatowany przedmiot badań i dociekań, głównie ze względu na współwystępowanie dwóch konkurencyjnych 
poglądów na ludzkie wnętrze. Badaczka wspomina o istnieniu dwóch fantazji w kulturze renesansu. Jedna mówiła o tym, że „»ja“ jest nieznane, ukryte, nieopisywalne; inna - że jest w pełni uzewnętrznione albo zdolne do tego, by być w pełni ujawnione" (28-29). Szekspir zdaje się preferować w Hamlecie pierwsze stanowisko.

Dodatkowo, w scenie spotkania z aktorami, Hamlet próbuje zrozumieć, co stałoby się na scenie, gdyby aktor miał taki jak on powód do rozpaczy. Bohater podkreśla, że aktor może udawać i perfekcyjnie stwarzać pozory głębokich uczuć. Wydaje się znaleźć odpowiedź na nurtujące go pytanie w takiej oto wypowiedzi na temat gry aktora:

\author{
Zalałby scenę łez potokiem, rozdarł \\ Słuchaczy uszy okropnościq mowy, \\ O szał przyprawił winnych, a przeraził \\ Niewinnych, zmieszał nieświadomych, zdumiat \\ Zaiste sam zmysł wzroku i zmysł słuchu (2.2.788-792).
}

Szekspir zwraca tym fragmentem uwagę na oddziaływanie percepcyjne między aktorem a publicznością. Daje ono możliwość wywołania zdumienia wizualnego i audialnego, a więc jednoczesnego wywarcia wpływu na zmysł wzroku i słuchu. Dramaturg sugeruje przywołanym wersem, że poruszenie obu zmysłów widzów-słuchaczy jest dla aktora sytuacją idealną. Iluzja rzeczywistości, jaką potrafi wyczarować aktor, jest dla Hamleta perfekcyjną iluzją, którą sam pragnie zaimprowizować. Książę ustala z aktorami, że odegrają „Morderstwo Gonzagi”. W tym miejscu Szekspir kreuje Hamleta na podstępnego sędziego, który pragnie wydać wyrok po zastawieniu „zasadzki” na winowajcę, przy jednoczesnym wykorzystaniu wiedzy o zmysłach. Hamlet opiera się na znajomości mechanizmu gry aktorskiej wraz z jej wpływem na odbiorcę:

\author{
Słyszałem ja o winowajcach, którzy \\ W teatrze siedząc doznawali wstrząsu \\ Takiego dzięki teatralnej złudy \\ Mistrzostwu, że swe zbrodnie wyznawali, \\ Albowiem mord, choć mu i brak języka, \\ Potężnym głosem wola. Tym aktorom \\ Przed stryjem każę grać coś podobnego \\ Do mordu ojca, w twarz mu będę patrzał \\ I tak wystawię na ogniową próbę; \\ Niech tylko zadrgnie, wiem już, co mam czynić (2.2.824-833).
}

Co więcej, Hamlet stwierdzając, że "Jutro posłuchamy / sztuki” (2.2.758-759), uwypukla znaczenie percepcji słuchowej w procesie odbioru przedstawienia. Zagadnieniem odbioru sztuk Szekspirowskich zajmuje się 
w pracy Playgoing in Shakespeare's London (2004) Andrew Gurr. Badacz traktuje odbiorców jako czynnych uczestników przedstawienia, których ulotna percepcyjna obecność w tamtych czasach należy jedynie do sfery przypuszczeń i domniemywań. Jedną z trudności w odtworzeniu doświadczeń percepcyjnych ludzi ery elżbietańskiej jest współczesna perspektywa badawcza wraz z jej fizycznymi warunkami.

Gurr twierdzi, że obecne warunki, jak na przykład siedzenie w trakcie przedstawień w wygodnych fotelach, w przyciemnionej sali, czy też praktyki audialne, dalekie są od stania na błotnistym dziedzińcu albo siedzenia na drewnianych ławkach przy świetle świec, które towarzyszyło ówczesnym odbiorcom (2004: 13). Zmiana kilku elementów, takich jak: oświetlenie sceny i miejsca na widowni, ekspozycja aktorów, będących niemalże na wyciągnięcie reki, czy też szybsze pojmowanie przekazów werbalnych, dzięki rozpowszechnionym praktykom słuchowym, nie zaś czytelniczym, spowodowała, że transformacji uległ cały proces zaangażowania zmysłów w sztukę. Jeśli potraktować zachowania percepcyjno-receptywne za ważny wskaźnik, odgrywający rolę w kształtowaniu podejścia do zmysłów jako konstruktów kulturowych, to przykład Hamleta pokazuje, że Szekspir zmienił terminologię w odniesieniu do odbiorców sztuk i po raz pierwszy w 1600 roku, właśnie w tej tragedii posłużył się słowem „widz” (110). Badacz dodaje, że ta data może wskazywać na zmianę w postrzeganiu odbiorców przez Szekspira, który „porzucił ideę słuchaczy i nazwał swych klientów widzami" (111). Nie oznacza to jednak, że główny bohater tragedii oddaje uprzywilejowane miejsce „oglądaniu”, wypierającemu „słuchanie”. Raczej, zdaniem Gurra, potępienie pantomimy przez Hamleta to przykład na niechciane wypieranie mowy przez widowisko (103). Chodzi tu między innymi o następujący fragmenty rozmowy Hamleta z aktorami:

Och, oburza mnie do żywego słuchać tęgiego chłopa w peruce, jak drze namiętność na strzępy, po prostu na szmaty, jak doprowadza do pęknięcia bębenki w uszach widzów z parteru, którzy po największej części umieją ocenić tylko niezrozumiałe pantomimy i hałas (3.2.240-246).

W ocenie badacza Szekspir - jeden z ważniejszych dramaturgów tamtego okresu - cenił efekt werbalny bardziej niż wizualny, co miało swoje konsekwencje w podejściu do odbiorców, wartościowanych przede wszystkim według zaangażowania ich postrzegania słuchowego.

\section{Sztuka zastawiania zasadzki}

Akt trzeci rozpoczyna dopracowanie szczegółów zasadzki, określonej przeze mnie jako „zasadzki percepcyjnej” (bowiem opartej na igraniu ze zmysłami), na Hamleta, przygotowanej przez Poloniusza i realizowanej we 
współpracy z Klaudiuszem. Szekspir w tej scenie portretuje Gertrudę i Ofelię jako postaci mało aktywne i percepcyjnie podporządkowujące się mężczyznom. Kobiecymi zmysłami skutecznie manipulują męskie postaci, powodując, że kobiece postrzeganie staje się uległe i pasywne. Kulturowe znaczenia postrzegania zmysłowego kobiet, wyrastające z literackich wyobrażeń doświadczeń związanych ze zmysłami, w sferze poznania nabierają biernego charakteru. Gertruda przystaje na to, co uknuł jej mąż oraz jego doradca-informator, słowami: „Posłuszna będę” (2.1.43). Projekt zasadzki przedstawia królowej Klaudiusz, który zaplanował, by Hamlet:

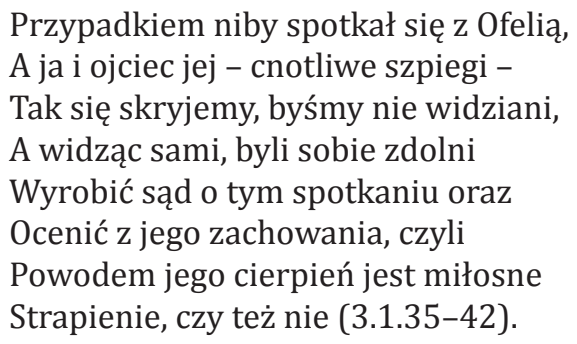

Ofelia natomiast dostaje od swojego ojca instrukcje co do "gry aktorskiej", którą ma się wykazać podczas spotkania. Należy zaznaczyć, że postaci Poloniusza i Ofelii wpisują się w renesansowy model patriarchalnego rodzica i posłusznej córki. Już w pierwszej scenie widoczne staje się, że ojciec steruje percepcją słuchową Ofelii. Reprezentacje kobiecych doświadczeń audialnych pokazują, że w czasach wczesnej nowożytności dużą wagę przywiązywano do odpowiedniego wychowania poprzez wywieranie wpływu na słuch. Poniekąd było to „dostrajanie” kobiet, niczym instrumentów muzycznych, do potrzeb i wymogów grającego. Poloniusz powołuje się na zasłyszane od kogoś informacje o „samotnych odwiedzinach” Hamleta u Ofelii. Green wspomina, że zabrania on córce spotkań z księciem, rozmów z nim, a tym samym wsłuchiwania się w zwodniczy głos Hamleta, ponieważ (jego zdaniem) dziewczyna nie potrafi odróżnić prawdy od pozoru („Poisoned Ears”). Ojciec w szczególności kładzie akcent na zmysł słuchu, co staje się „słyszalne” także w trakcie instruowania brata Ofelii, Laertesa. 0 ile dziewczyna ma zakaz zarówno słuchania, jak i rozmawiania z Hamletem, o tyle Laertesowi ojciec daje następującą wskazówkę:

\author{
Miej ucho \\ Dla wszystkich, ale głos li dla niewielu, \\ Wysłuchuj wszystkich zdań, lecz swoje własne \\ Dla siebie chowaj (1.3.599-601).
}


W przemowie Poloniusza reprezentacją zmysłu, który staje się otwarty na głosy innych, jest narządu słuchu. Ucho jawi się jako organ filtrujący informacje i pozwalający na podjęcie odpowiedniej decyzji po zasłyszeniu wieści; decyzji o podjęciu dialogu albo wycofaniu się. Jeśli chodzi o postrzeganie Ofelii, to wyraźnie zarysowuje się wyobrażenie kontrastujące z męską reprezentacją słuchu. Odmienność polega na tym, że jej uszy powinny stać się całkowicie "niedostępne” dla słów księcia. Wyznania miłosne Hamleta i jego przysięgi stają się zakazanymi dźwiękami, które „są pośrednikami innej barwy, / Niż ich zewnętrzna okazuje szata" (1.4.669-670).

Co ciekawe, również brat przestrzega Ofelię przed złudnością i ulotnością słownych obietnic Hamleta. Laertes, podobnie jak Poloniusz, akcentuje podatność słuchu na manipulację słowem: „Zważcie też, jak dotkliwą stratą grozi / Czci waszej na pieśń jego nazbyt ufne / Mieć ucho" (1.3.551-553). Laertes insynuuje, że „otwartość” narządu słuchu Ofelii na uwodzące słowa może prowadzić do otwartości seksualnej organów jej ciała. Zestawiając oba wyobrażenia organu słuchu, kobieca reprezentacja tego narządu postrzegania pokazuje, że nabiera on wymiaru seksualnego, zaś w przypadku reprezentacji jego męskiego odpowiednika jest on łączony ze sferą umysłową. Uszy Laertesa mogą pozostać „otwarte”, ponieważ zdoła on mocą intelektu odróżnić informacje prawdziwe od fałszywych. Natomiast uszy Ofelii są organami bardziej somatycznymi niż umysłowymi, dlatego nałożenie ograniczeń na jej narząd słuchu wiąże się z zapewnieniem nienaruszalności sfery seksualnej dziewczyny.

Poloniusz używa wobec córki strofujących zwrotów i pouczających sformułowań, podkreślając zwodnicze możliwości słowa w stosunku do ufnej Ofelii. Ostatecznie wydaje ojcowskie polecenie:

Nie chcę,

Po prostu mówiąc, byście od dziś mieli

Ubliżyć tak chociażby jednej chwilce

Swojego czasu, by wymieniać słowa

$\mathrm{Z}$ księciem Hamletem albo z nim gawędzić.

Zważajcie na to, tak wam nakazuję (1.4.674-679).

Kolejne polecenie Poloniusza dotyczy zaaranżowanego spotkania Hamleta i Ofelii - wizualnej przynęty. Dziewczyna dostaje instrukcje co do sposobu zachowania w obecności Hamleta. Chodzi tu o pozorowanie odmawiania modlitwy przez Ofelię z książki do nabożeństwa. W takiej sytuacji zastaje ją Hamlet, a całe zajście obserwują dwaj „cnotliwi szpiedzy” (3.1.36), czyhający w ukryciu. Green odnotowuje, że w trakcie spotkania i Hamlet, i Ofelia zmuszeni są milczeć o „sekretach” swych ojców („Poisoned Ears”). Jak podaje badaczka, „zarówno Hamlet, jak i Ofelia płacą za swoje milczenie, ponieważ 
owe sekretne rozkazy mają katastrofalne konsekwencje” („Poisoned Ears”). Obydwoje są zatem skazani na przekazywanie sobie zafałszowanych informacji: wizualnych i audialnych. Szekspir powtórnie eksponuje w tej scenie duże możliwości manipulacji ludzkimi zmysłami.

Hamlet dostrzega klęczącą Ofelię, inscenizującą pogrążenie w modlitwie. Stwarzając pozory odosobnienia, dziewczyna „kamufluje” obecność podpatrujących spotkanie Poloniusza i Klaudiusza. W artykule „Painted Women: Annunciation Motifs in Hamlet" Chris R. Hassel twierdzi, że zaaranżowane spotkanie stylizowane jest na biblijny motyw zwiastowania. Ofelia miałaby w tej scenie wcielać się w rolę Marii, która oczekując na zwiastowanie, klęczy i oddaje się modlitwie (1998: 47). Jednak Ofelia, w przeciwieństwie do Marii, jedynie pozoruje „bogobojną minę” oraz „zbożne czyny” (3.1.56). Hamlet wystawia na próbę uczucia dziewczyny, która pozostaje posłuszna ojcu i nie zdradza powodów swojej prośby, by mężczyzna zabrał ofiarowane jej listy miłosne. Co ciekawe, Ofelia na początku rozmowy wydaje się mieć przewagę nad Hamletem, gdy ceremonialne oddaje mu "pamiątki” (3.1.110). Gest i towarzyszące mu słowa odrzucenia powodują u Hamleta wybuch gniewu. Przyjmuje on formę potyczki słownej, którą steruje „uzbrojony” w retoryczne narzędzia językowe książę.

Kreując w tej scenie Hamleta na mistrza skutecznej argumentacji, Szekspir podkreśla przewagę językową księcia w „zdominowanej przez mężczyzn, retorycznej kulturze" renesansu (Luckyj, 2002: 42). W rezultacie Ofelia staje się celem werbalnego ataku mężczyzny, który odsłania iluzoryczność ludzkich zachowań. Zasadzka zastawiona na Hamleta stanowi dla niego sposobność do potwierdzenia tego, co pragną usłyszeć i zobaczyć zaczajeni za arrasem król i jego doradca - mianowicie, że powodem szaleństwa jest odtrącenie jego zalotów przez Ofelię. Jest tylko formą domysłu stwierdzenie, że Szekspir daje w tej scenie do zrozumienia, iż Hamlet zdaje sobie sprawę z bycia podsłuchiwanym i podpatrywanym. Krytycy spierają się w tej kwestii, jak na przykład Dover Wilson, który uważa, że Hamletowi przypadkowo udaje się usłyszeć o zorganizowanym spotkaniu, i stąd też jego bojowe nastawienie w rozmowie z Ofelią (What Happens in Hamlet, 1935: 103). Arthur Noel Kincaid podważa tezę Wilsona w artykule „Hamlet's Cue for Passion in the Nunnery Scene", twierdząc, że w sztuce trzykrotnie występuje jawny motyw podsłuchiwania: Klaudiusz podsłuchujący jednokrotnie oraz Poloniusz dwukrotnie (choć w jednej ze scen podsłuchują wspólnie) (1977: 99-100). Badacz stoi na stanowisku, że Szekspir często wykorzystywał ten zabieg w dramatach i szedł on w parze z oczywistym ujawnianiem „podsłuchiwania” w treści danej sztuki (100).

W efekcie można przyjąć, za autorem Through Shakespeare's Eyes (2010), Josephem Pearce'em, że Hamlet wie, iż dwór Klaudiusza to dobrze zaprojektowana „sieć szpiegów” (2010: 132). Pośród nich znajdują się „ci, którzy sq 
tymi [osobami], którymi mówią, że są”, oraz „ci, którzy nie sq̨ tymi [osobami], którymi mówią, że są" ([podkreślenie autora] 132). Szekspir wprowadza także pewne zamieszanie, ukazując niepewność Hamleta co do przynależności Ofelii do grupy szpiegów, skupiającej postaci jedynie „wydające się prawdziwymi, szczerymi albo realnymi" $(132)^{7}$.

Scena spotkania Hamleta i Ofelii to swego rodzaju „walka zmysłów”, walka między tym, co zasłyszane i powiedziane, oraz między tym, co zauważone i zaobserwowane. Rywalizacja toczy się pomiędzy wzrokiem i słuchem w takim sensie, że oba zmysły dostarczają odmiennych informacji, a przez to rozbieżnej wiedzy na określony temat. Dodatkowo sprawę komplikuje genderowy sposób postrzegania przez kobiety i mężczyzn, różny z przyczyn kulturowych dla każdej z płci. Odejście Hamleta wprawia sferę wrażeń percepcyjnych Ofelii w stan dezorientacji, co skłania ją do następujących przemyśleń:

0 , jak szlachetny duch tu runął w gruzy!

Oko, miecz, język dworzanina, mędrca,

Żołnierza; przyszłość i rozkwitająca

Róża świetnego państwa; obyczajów

Zwierciadło; forma kształtująca przyszłe

Posągi; ten, co wszystkie ścigał oczy -

Ach, jakże nisko legł! a ja, nad wszystkie

Niewiasty poniżona, ja, nędzarka,

Com miody ssała z dźwięcznych jego ślubów,

Dziś świadkiem jestem, jak szlachetny jego

I przodujący rozum, niby dzwony

Skłócone z sobq, niemelodyjnymi

Odzywa się zgrzytami; niezrównany

Młodości kwiat zwarzony jest przez podmuch

Obłędu. Za cóż to mnie los tak karze,

Że na to patrzeć kazał mi i każe? (3.1.179-194).

Powyższy fragment można zinterpretować jako lament Ofelii nad utraconym „brzmieniem” głosu Hamleta. Bohaterka „przyzwyczaiła się” raczej do melodyjnych wyznań Hamleta niż do chaotycznych, agresywnych i nieprzyjemnych dla ucha dźwięków. Tak bowiem można podsumować pełne prze-

\footnotetext{
${ }^{7}$ W swojej interpretacji Pearce przywołuje podobieństwo pomiędzy dworem Klaudiusza a dworem Elżbiety I. Wczesnonowożytne praktyki śledzenia jednych przez drugich, informowania i donoszenia były popularnymi metodami zdobywania informacji przez królową (2010: 134). McDermott powołuje się na pracę Alana Haynesa (Invisible Power: The Elizabethan Secret Service, 1992) i podaje, że służby wywiadowcze na dworze elżbietańskim były zobowiązane do działalności w postaci „niewidzialnych sił”, które miały tropić różnego rodzaju „widoczne” wykroczenia poprzez sieć potajemnie działających agentów („Perceiving Shakespeare").
} 
mocy werbalnej wypowiedzi księcia. Ofelia, będąc świadkiem odmiennych zachowań ukochanego, po raz drugi nie rozpoznaje w nim dawnego Hamleta. Jej słowa: „Tym bardziej się zawiodłam” (3.1.140) wyrażają żal z powodu bycia oszukaną, zwiedzioną i zmanipulowaną gestami-widokami (pozorami) oraz melodiami-dźwiękami (brzmieniem).

Pierwsze spostrzeżenia Ofelii odnoszą się do jej relacji z (omówionej już wcześniej) niespodziewanej wizyty, jaką złożył jej Hamlet, a którą zrelacjonowała ojcu. Podczas tego spotkania milczący książę „przemówił” swym niecodziennym wyglądem oraz jednym głębokim westchnieniem. Początkowo zatem różnicę w stylu bycia „dostrzegają” jedynie jej oczy. Drugie spotkanie stanowi potwierdzenie zmiany w wyglądzie przez zmianę w wypowiedziach. Ofelia zauważa też przemianę w sposobie mówienia mężczyzny, co ma świadczyć o obłędzie, w jakim pogrążył się książę. Uczestnicząc w jego zmianach postrzegania, Ofelia staje się naocznym i słuchowym świadkiem aktorskich transformacji Hamleta. Z jednej strony można więc przyjąć, że jej zmysły są podatne na manipulacje, z drugiej zaś, że prawidłowo odczytuje wysyłane przez księcia oznaki szaleństwa, na czym zależało, reżyserującemu swój obłęd, Hamletowi.

W komentarzu do monologu Ofelii McDermott podaje, że jest to „moment rozpoznania", moment, kiedy dziewczyna zaczyna zdawać sobie sprawę, iż została zwiedziona. Portretując Hamleta w sposób werbalny, rozpoczyna od skojarzeń wzrokowych, jak na przykład: „oko”, „Zwierciadło”, „miecz” (wizualny atrybut bohatera), by przejść do odniesień z zakresu percepcji słuchowej. Zdaniem badaczki, mimo powtórnego przejścia do określeń wzrokowych, „chwilowy zwrot w kierunku dźwięku świadczy o przebudzeniu” Ofelii („Perceiving Shakespeare”). Bohaterka w końcu staje się „audialnie uważna”, ponieważ dzięki owemu „przebudzeniu” zaczyna poszukiwać znaczeń słuchowych. Jednak nie chodzi tylko o ich melodyjną dźwięczność, ale też o znaczenie słów jako elementów mowy („Perceiving Shakespeare”).

Po oddaleniu się Hamleta Klaudiusz i Poloniusz ostatecznie diagnozują jego stan emocjonalno-umysłowy. Obaj ignorują spostrzeżenia Ofelii, dając do zrozumienia, że świadectwa jej zmysłów nie mają znaczenia intelektualnego, klasyfikując je tym samym jako mało przydatne doświadczenia cielesne. Król sugeruje, że obłęd Hamleta nie ma podłoża miłosnego, lecz

Jest w jego duszy coś, co melancholia

Jego wylęga; gdy się to wykluje

I uwidoczni, będzie niewątpliwie

Czymś niebezpiecznym (3.1.199-203)

${ }^{8}$ Analizą melancholii zajął się Robert Burton, który w pracy The Anatomy of Melancholy (1621) wykracza poza naukowe studium tego zjawiska jako choroby mentalnej i nakreśla wiele jej powiązań z kulturą. Choć Burton bezpośrednio nie bada „przypadku” Hamleta, jego 
Klaudiusz uknuwa plan wysłania Hamleta do Anglii, by odmienne „widoki” przegnały dotychczasowe, a mianowicie - „tę rzecz, która / Już tam zadomowiła się po trosze, / O którą wiecznie jego mózg potrąca" (3.1.208-210). Scena ta potwierdza, że konspiracja mężczyzn pozwala im nie tylko na bieżąco konsultować wyniki śledztwa czy obmyślać dalsze zasadzki percepcyjne, ale także podczas tych przedsięwzięć podwójnie wytężać zmysły. Nasuwa się tutaj spostrzeżenie, że mężczyźni w Hamlecie działają zespołowo. Przykładem jest „krąg wtajemniczonych” w opowieść ducha (Hamlet, Horacjo, Bernardo, Marcellus) albo właśnie alians Poloniusza z Klaudiuszem.

W owym sojuszu Gertruda zostaje umieszczona przez Szekspira na ambiwalentnej pozycji, ponieważ nie jest pomysłodawczynią żadnej z prowokacji. Jej rola sprowadza się do biernego spiskowania, co wskazuje także na receptywny charakter kobiecego postrzegania zmysłowego. Z dramatu wyłania się kulturowa reprezentacja aktywnych zmysłów wzroku i słuchu jako męskich narzędzi wiedzy i władzy. Szekspir ukazuje na tym etapie sztuki, że rola kobiet sprowadza się raczej do bycia cieniem męskich form i echem męskich głosów, aniżeli do bycia „agentkami”, prowadzącymi własne intrygi. Ofelia i Gertruda wydają się niezainteresowane spiskowaniem między sobą, za plecami mężczyzn.

W wyniku narady pomiędzy królem i jego doradcą ten ostatni popiera pomysł władcy, choć dodaje też własny element do dalszego śledztwa:
Może po przedstawieniu jego matka
Królowa go poprosi w cztery oczy,
Aby wyjaśnił jej swe przygnębienie.
Niech będzie z nim stanowcza, mnie zaś, proszę,
Umieśćcie tak, by cała ta rozmowa
Nie uszła mego ucha (3.2.220-225).

Dramaturg powtórnie stwarza sytuację, w której kobieta ma posłużyć jako przynęta, mająca spowodować, że Hamlet wpadnie w zastawione na niego sidła. Podobnie jak Ofelia, także Gertruda nie pozostanie bez tajnej asysty, ukrytej za arrasem. Dodatkowa para uszu ma czuwać nad przebiegiem rozmowy. Można zatem wysunąć wniosek, że „słuchowa naoczność” (jak to oksymoronicznie określam) staje się dla Poloniusza kluczową metodą szpiegowską. Kolejny raz aranżuje on spotkanie między Hamletem i kobietą, tym razem jego matką, licząc na skuteczne wprowadzenie percepcyjnego mętliku w głowie księcia. Tym samym pragnie potwierdzenia swej interpretacji odkrycia źródeł jego szaleństwa.

opis przyczyn i symptomów melancholijnych pasuje do sytuacji tej fikcyjnej postaci. Warto między innymi zaznaczyć spostrzeżenie Burtona, że melancholicy widzą zmarłych „oczami wyobraźni” (305). Zatem Hamlet już na początku sztuki zdradza objawy tej choroby, której źródło tkwi w utracie ojca. 


\section{„Pułapka na myszy" albo pułapka na zmysły}

W drugiej scenie aktu trzeciego Szekspir doprowadza akcję dramatu do punktu, w którym nawarstwione percepcyjne szumy i niejasności zostaną w formie sztuki-w-sztuce odtworzone przed oczami i uszami mieszkańców Elsynoru. Hamlet poucza aktorów, jak mają grać w przedstawieniu - mianowicie tak, by ich gra poruszyła jednocześnie zmysł wzroku i słuchu. Będąc głównym reżyserem i inscenizatorem „Morderstwa Gonzagi”, mówi też aktorom, że celem ich sztuki „zawsze i teraz było i jest podawać niejako zwierciadło naturze, pokazywać cnocie jej własne rysy, sromocie jej własne oblicze, a samemu wiekowi i postaci czasów ich odbicie i plastyczny obraz" (3.2.257-261). W przypadku operacji słowem, mowa powinna być „żywa i płynna” (3.2.232), niewpadająca w „fałszywy patos” (3.2.233), zaś gesty dalekie od „sieczenia” „zbytnio powietrza rękami” (3.2.236). Złotą zasadę zawiera Szekspir w poradzie Hamleta skierowanej do aktorów: „Stosujcie / ruchy do słów, a słowa do ruchów" (3.2.252-253). Dzięki tej regule oddziaływanie na zmysły powinno przynieść zamierzony efekt - dotrzeć zarówno do uszu, jak i do oczu zebranych, w tym w szczególności spowodować nieoczekiwaną reakcję percepcyjną Klaudiusza: „Niech przedstawienie / Zdradzi, co kryje królewskie sumienie" (3.2.840-841). Hamlet ujawnia sekret inscenizacji Horacjowi, prosząc, by jego zmysły działały z nadzwyczajną przenikliwością i wytężeniem:

Bacznie patrz na niego,

Bo ja przykuje wzrok do jego twarzy,

A potem sądy mój i twój się złączą,

By o wyglądzie jego wydać wyrok (3.2.332-335).

Hamlet akcentuje znaczenie oblicza Klaudiusza, zapowiadając odczytywanie różnych zmian zewnętrznych z mimiki jego twarzy, na której - jak w soczewce - mają się skupić istotne stany wewnętrzne. Paradoksalnie też Hamlet, który wcześniej oznajmia, że wszelkie dające się manifestować przejawy wnętrza są nieprawdziwe (gdyż można je udawać), korzysta z metody, której zadaniem jest zdekonspirowanie złoczyńcy przez jego niekontrolowane uzewnętrznienie winy. W ocenie Grace Tiffany, autorki artykułu „Anti-Theatricalism and Revolutionary Desire in Hamlet (Or, The Play Without the Play)”, „[w]ielki paradoks Hamleta polega, oczywiście, na tym, że jego odraza $\mathrm{w}$ stosunku do teatralnej pustki wydaje się wynikać z jego zafascynowania siłą dramatycznej reprezentacji" (1995: 69). Badaczka stoi na stanowisku, że w Hamlecie Szekspir prezentuje postawę podobną do antyteatralizmu purytan. Cechami charakterystycznymi tego podejścia były niechęć i brak zaufania do „teatralnych »pokazów«”, odbywających się zarówno w teatrze, 
jak i w szerszym zakresie działań społecznych, na przykład religijnych czy politycznych (61). Można też pokusić się o inne stwierdzenie, że Szekspir w tym przypadku docenia „teatralnej złudy mistrzostwo” oraz jej obnażającą siłę. Teatr jawi się więc jako specyficzne miejsce, powodujące katarktyczne przeżycia jednostki. W ocenie Eisaman Maus okres wczesnej nowożytności był owładnięty wątpliwościami w zakresie autentyczności/nieprawdziwości, a sam teatr postrzegano w kategoriach „sztuki niekompletności: formy manifestowania, która wystawia na pokaz jego ograniczenia" (210).

Historia opowiedziana przez ducha zostaje przekazana przez Hamleta, a dosłownie - przez gesty aktorów. Książę, który przyobiecał, że nie wyjawi jej szczegółów, w końcu znajduje sposób na przerwanie milczenia. Zdarzenie, mające tylko dwóch świadków, spośród których zaledwie jeden pozostał przy życiu, zostanie $\mathrm{z}$ istotnymi zmianami przywołane $\mathrm{w}$ niemym spektaklu. Hamlet pragnie, by plotka na temat śmierci jego ojca - która stała się prawdą przez rozgłoszenie jej w wersji oficjalnej - przestała być informacją zniekształcającą rzeczywistość. Dodatkowo scena ta pokazuje, że dla Hamleta jest to sprawdzian wiarygodności narracji ducha.

Pierwszą próbą dla zmysłów dwóch postaci śledzących Klaudiusza, a także dla zmysłów śledzonego, jest pantomima, będąca skróconą wersją przedstawienia. Stanowi ona test dla percepcji wizualnej widzów, którzy jedynie dzięki uważnej obserwacji mogą odczytać przekaz w postaci obrazu. W dramacie pojawia się sztuka-w-sztuce, pozwalająca na wgląd w stany percepcyjne wielu postaci naraz. Scena pantomimiczna przedstawia okazującą sobie miłość parę królewską w ogrodzie. Gesty klękającej przed królem żony sugerują, że składa mu przysięgę. Zaraz potem królowa, widząc, jak król usypia, oddala się, zostawiając go samego. Następnie odegrana zostaje scena, w której król zostaje uśmiercony poprzez wlanie mu trucizny do ucha. Królowa zastaje martwego małżonka, po czym wpada w rozpacz. Jednak smutek nie trwa zbyt długo, bo zabójca króla skutecznymi zalotami zdobywa jej serce. Zdaniem Kelleya, pantomima stanowi przełożenie opowieści ducha na „czystą akcję" (98). Ponieważ sama akcja nie wyjaśnia tyle co pokaz, w połączeniu ze słowami, stąd dalsza część sztuki-w-sztuce zostaje zwerbalizowana. Według autorki Drugs and Theatre in Early Modern England (2005), Tanyi Pollard, „tym, co stanowi dla Hamleta najbardziej porażającą siłę w teatralnym przedstawieniu, jest dźwięk i jego zdolność do oddziaływania na narząd słuchu" (139).

Pantomima, pozbawiona „komentarza” w postaci kompletnego spektaklu, może być potraktowana jako odtworzenie opowieści ducha. Klaudiusz mógłby identyfikować się z zabójcą śpiącego króla. Jednak w drugiej części sztuki Hamlet szykuje niespodziankę w formie objaśnienia, że ten, który przygotował truciznę: „To jest niejako Lucjan, bratanek króla” (3.2.504). Wcześniej, zapytany przez Klaudiusza, książę objaśnia tytuł sztuki: „»Łapka 
na myszy«. No, a skąd? Obrazowo. Dramat opiera się na morderstwie popełnionym w Wiedniu. Książę nazywa się Gonzago, żona jego Baptysta. Zaraz zobaczycie. Łajdacka sztuka" (3.2.496-499). Pułapka zastawiona przez Hamleta oddziałuje na Klaudiusza mocą werbalnego przekazu. Newralgiczna część ciała, jaką dla króla jest ucho, zostaje wyeksponowana w sztuce w taki sposób, by nie budzić wątpliwości co do sposobu zabójstwa władcy. Widok zostaje wzmocniony słowami wypowiadanymi przez aktora grającego Lucjana:

Czarne myśli, dłoń pewna, lek, co nie zawodzi, Jak w zmowie ze mną chwila! Nikt mi nie przeszkodzi.

Wywarze z ziół zrywanych, kiedy północ była,

Hekaty przekleństw w tobie jest potrójna siła.

Przyrodzoną swą władzę, jaką masz w ukryciu,

Przeciwko zdrowiu skieruj, przeciwko życiu! (3.2.517-522).

Po wypowiedzeniu tych słów aktor-Lucjan wlewa truciznę do uszu króla. Pollard uważa, że

magiczne słowa Lucjana zdają się stanowić klątwę, która ucieleśnia zatruwającą moc performatywnego języka. Jego magiczne przywoływanie i śpiewny rytm nasuwają na myśl świat o zwiększonej językowej skuteczności; słowa są jego „wywarem”, jego „ziołami, zrywanymi, kiedy północ była”. [Z kolei] fizyczny gest wlewania trucizny do ucha jest spóźnionym echem, niemalże podporządkowanym słownej groźbie, którą [Lucjan] inscenizuje (2005: 139).

O toksycznym oddziaływaniu języka pisze też Lee Sheridan Cox w pracy Figurative Design in Hamlet. The Significance of the Dumb Show (1973). Przede wszystkim porusza wątek otrucia ojca Hamleta przez Klaudiusza poprzez wpuszczenie trucizny do jego uszu. Pomimo wielu odniesień w sztuce do tego narządu ciała, właśnie wyobrażenie zainfekowanego ucha prowadzi do analizy kolejnego związku. Chodzi tu o metaforyczne wdarcie się do organizmu innej trucizny - niebezpiecznych słów, gdyż „mowa może mieć destrukcyjne właściwości trucizny albo choroby" (51). Z punktu widzenia Cox, istnieje powiązanie pomiędzy wlewaniem do uszu trucizny, toksycznością języka oraz słuchaniem, w konsekwencji prowadzącym do zepsucia i upadku.

Wprowadzając sztukę do sztuki, Szekspir jednocześnie wprowadza do niej wątki o charakterze dosłownym, jak i przenośnym; wątki z przeszłości oraz niespełnione fantazje i obawy; wątki wyobrażeniowe, niemalże prorocze. Wpływ przedstawienia na zmysły Klaudiusza odnosi skutek o tyle, że Hamlet otrzymuje potwierdzenie, iż opowieść ducha była prawdziwa. $\mathrm{Na}$ wyreżyserowane otrucie bohatera „Morderstwa Gonzagi” Klaudiusz reaguje ostentacyjnym wyjściem z komnaty i komentarzem: „Poświećcie mi - chodźmy stąd!" (3.2.533). Dosłownie jest to somatyczna reakcja podobna do odczuć towarzyszących omdlewaniu. Symbolicznie zaś można potraktować 
owo nawoływanie niczym przyznanie się do chwilowego oślepnięcia. Drugim świadectwem jest widok klęczącego i wyznającego swe winy samotnego Klaudiusza, który nie wie, że jest obserwowany przez Hamleta. Szekspir prawdopodobnie sugeruje, że to obraz modlącego się grzesznika wstrzymuje Hamleta przez dokonaniem zbrodni. Widok, choć znów może być jedynie „atrapowy”, powstrzymuje działanie.

Wydaje się, że u Klaudiusza lepiej funkcjonuje zmysł audialny, zaś jego doświadczenia $w$ tym zakresie są intensywniejsze niż doświadczenia wizualne. Zdaniem Diede, Klaudiusz posiada uwrażliwiony słuch w sensie politycznym. Zdolność ta pozwoliła mu na zlikwidowanie i pozbycie się brata. Przyczynił się też on poniekąd do rozpropagowania plotki i użycia jej do zawładnięcia wyobraźnią mieszkańców Danii (2008: 115). Brak reakcji Klaudiusza na pantomimę można zinterpretować w kategoriach metaforycznego „osłabienia” wzrokowego w porównaniu z wyostrzeniem słuchu. Jednak po wysłuchaniu (oraz obejrzeniu) sztuki, także organ audialny zaczyna nieco inaczej u niego funkcjonować. McDermott dopatruje się takiego stanu w tym, że „[t]ak jak człowiek cierpiący na infekcję ucha, on [Klaudiusz] również nie jest zdolny do precyzyjnego słuchania, co jest skutkiem choroby jego własnej duszy” („Perceiving Shakespeare”). Badaczka dodaje, że Klaudiusza można w sposób figuratywny przyrównać do „zablokowanego ucha” („Perceiving Shakespeare").

Z kolei Hamlet pełni w trakcie przedstawienia rolę „dodatkowego głosu" (chóru) w sztuce. Wtrąca dodatkowe objaśnienia, wdaje się w dłuższą rozmowę z Ofelią i udziela odpowiedzi na pytania. Choć nigdy dosłownie nie wchodzi na scenę, i tak „występuje” na niej jako rzucający się w oczy i hałaśliwy reżyser. Co więcej, sama treść „Pułapki na myszy” powoduje, że „trzymana w tajemnicy wewnętrzna tożsamość Hamleta przedostaje się do sztuki" (Selleck, 2008: 68). Szekspir może dawać do zrozumienia, że tego typu „uzewnętrznienie się” Hamleta to jednocześnie zagrożenie dla aktualnie sprawującego władzę. Jednak tego bezpośredniego ryzyka nie wychwytują organy percepcyjne obecnych na sali Gertrudy i Ofelii. A przecież pantomima oraz następująca po niej zwerbalizowana wersja sztuki stanowią także sprawdzian dla zmysłów kobiet. Dramaturg wykreował w tym celu kobiece doświadczenia sensoryczne, towarzyszące Ofelii i Gertrudzie w trakcie oglądania i słuchania treści sztuki.

W artykule „»The Play's the Thing«: The Play Scene in Hamlet” Marta Gibińska zauważa, że wystawienie pantomimy jest głównie skierowane do Gertrudy. Badaczka stoi na stanowisku, że całe przedstawienie składa się z dwóch odrębnych elementów: pantomimy i sztuki z recytacją, ale pierwszy element wcale nie stanowi próby dla kolejnego (1993: 176). Zdaniem Gibińskiej: „Pantomima rozpoczyna się w kontekście Gertrudy, a nie Klaudiusza” (180). Jeśli przyjąć taki tok rozumowania, to królowa, do której adresowany 
jest niemy spektakl, pozostaje niema - pozostawia pantomimę bez komentarza. Odzywa się dopiero w trakcie drugiego przedstawienia, by udzielić odpowiedzi na zapytanie Hamleta: „Pani, jak podoba się wam ta sztuka?” (3.2.487). Ponieważ pytanie pada tuż po tym, jak aktorka grająca królową wypowiada słowa przysięgi, stąd reakcja Gertrudy: „Zdaje mi się, że dama czyni za wiele uroczystych / przyrzeczeń" (3.2.489-499). Królowa wskazuje tą wypowiedzią, że jej uszy „wychwytują” sens sztuki oraz prawdopodobnie aluzję do sytuacji, w której znalazła się po śmierci męża. Może być ona zatem w stanie lekkiego percepcyjnego podenerwowania czy też dyskomfortu, lecz z pewnością nie odczuwa zagrożenia ze strony Hamleta. Sztuka-w-sztuce stanowi próbę pobudzenia jej zmysłów. Jest to swego rodzaju przemówienie obrazem i zobrazowanie mową, jednak królowa zdaje się mieć - w sensie metaforycznym - przytępione oba zmysły w ich umysłowym wymiarze. Można pokusić się o stwierdzenie, że zwłaszcza somatyczny aspekt zmysłów przyćmiewa zdolność do rozróżnienia między fałszywymi a prawdziwymi słowami oraz pozornymi a autentycznymi widokami.

Alex Aronson w książce Shakespeare and the Ocular Proof (1995) twierdzi, że w patriarchalnym społeczeństwie, które Szekspir przedstawił w swoich sztukach, kobiety najczęściej ukazane są jako obiekty wyboru, nie zaś jako postaci podejmujące wybory. Jeśli jednak bohaterka Szekspirowska dokonuje wyboru mężczyzny, czy to kochanka, czy męża, jest to decyzja podyktowana błędnym rozpoznaniem. Chodzi tu o zaślepienie, które charakteryzuje decyzje należące do postaci kobiecych $\mathrm{w}$ dramatach Szekspira. Aronson ujmuje to następująco: „ich [bohaterek] zdolność widzenia jest podatna na bycie zwodzoną na manowce” (15-16). Innymi słowy, „oko ciała” (wspomniane już przy okazji omawiania dualizmu kartezjańskiego) błądzi, ulega zaślepieniu i emocjom. Niejednokrotnie kobiece wybory są podyktowane przez erotyczne impulsy. Widzenie o zabarwieniu emocjonalnym stanowi przeciwieństwo dla widzenia powodowanego rozumowym osądem. To ostatnie uznawane było za domenę mężczyzn i kulturowo przewyższało inne formy postrzegania wzrokowego. Szekspir, portretując królową, może sugerować, że Gertruda oparła swoją decyzję o ponownym zamążpójściu na wizualnych oznakach miłości, które jak każdy zewnętrzny przejaw uczuć, są niesprawdzalne pod względem autentyczności. Pantomima podkreśla, że królowa otrzymuje dary od zalotnika. W połączeniu z odpowiednimi gestami, mogły one przekonać Gertrudę, podobnie jak „milczącą” bohaterkę pantomimy.

McDermott wskazuje, że „[b]łędy percepcyjne Gertrudy towarzyszą poleganiu jedynie na zmyśle wzroku” („Perceiving Shakespeare”). Badaczka analizuje sceny, z których wyłania się kobieca reprezentacja percepcji wzrokowej. W przypadku Gertrudy jest to chociażby jej uwaga na temat wyglądu Hamleta: „Lecz, patrz, nadchodzi smętny biedaczysko, / Czytając” (2.2.340-341), albo, gdy dopatrując się podłoża szaleństwa swego syna, szuka wzrokowego 
bodźca, stwierdzając: „Co do was zaś, Ofelio, najgoręcej / Pragnęłabym, by wasza to uroda / Przyczyną była Hamletowych dziwactw” (3.1.43-45) („Perceiving Shakespeare"). Istotny wydaje się tutaj aspekt potraktowania Ofelii w kategoriach wizualnych, poniekąd sprowadzenie jej do obiektu seksualnego, który niczym wabik, miał przyciągnąć uwagę Hamleta. W sztuce staje się jasne, że przede wszystkim mężczyźni traktują Ofelię w tych kategoriach; zwłaszcza Hamleta ożywia widok dziewczyny. Potwierdzają to jego określenia w listach odnoszące się do ocen wzrokowych: „Do niebiańskiej, będącej nam bożyszczem, wszelką pięknością błyszczącej Ofelii" (2.2.270-271) albo „jej cudne, bieluchne łono” (2.2.273).

W scenie „Pułapka na myszy” Hamlet nawiązuje dialog z Ofelią, przeradzający się w zestaw publicznie wygłaszanych, nieprzyzwoitych aluzji. Nie są one podobne do górnolotnych wyznań i „niebiańskich zaklęć” (1.4.652), które kierował do Ofelii w listach oraz prywatnych rozmowach. Hamlet celowo rozgrywa ten dialog tak, by dalej stwarzać pozory nieszczęśliwie zakochanego szaleńca. Ofelia zatem kolejny raz staje się celem werbalnego uwłaczania, a nawet zniesławiania. Odnosi się do komentarzy Hamleta z rezerwą, traktując je bardziej jako sprośne żarty i poniekąd pozostając na nie „głucha”. Kontrowersyjna konwersacja zostaje przerwana przez pantomimę, po zakończeniu której dziewczyna próbuje pojąć sens sztuki. Co ciekawe, akurat Ofelia wydaje się najbardziej dociekliwa: „Co to znaczy, mości książę?” (3.2.392), „Może ta pantomima mieści w sobie treść sztuki?” (3.2.395). Pyta także o aktora: „Czy on wyjaśni to, co nam pokazali?” (3.2.399).

Reprezentacje zmysłów Ofelii wskazują na konieczność uzupełnienia wrażeń wizualnych audialnymi. Po raz kolejny w Hamlecie pojawia się zapotrzebowanie na dalsze objaśnienia językowe. Na przykładzie Ofelii Szekspir pokazuje, jak niekompletne są jedynie doświadczenia wizualne, oraz to, że „zobaczyć” nie jest równoznaczne ze „zrozumieć”. W dodatku właśnie ona jako pierwsza dostrzega reakcję Klaudiusza na przedstawienie, podnosząc alarm słowami: „Król wstaje!” (3.2.528). To z kolei może świadczyć, że jest postacią spostrzegawczą, lecz - jak pokazują wcześniejsze sceny - jej optyka jest zdominowana męskim punktem widzenia. Ojciec, brat oraz Hamlet kształtują i ograniczają jej perspektywę poznawczą praktycznie na każdym kroku. Szekspir ukazuje tym samym kulturową marginalizację kobiecego „spojrzenia” na korzyść męskiego postrzegania.

Natomiast Poloniusz pozostawia sztukę bez bezpośredniego komentarza, prawdopodobnie oczekując w pierwszej kolejności reakcji króla i królowej. Jego ponowne pojawienie się w sztuce będzie zarazem stanowiło jego ostatni w niej udział, bo następna scena dramatu przenosi akcję do komnaty królowej, gdzie za arrasem czeka już przygotowany do podsłuchiwania szpieg Klaudiusza. 


\section{„Przemawianie sztyletami” $i$ „pokazywanie duszy głębi”}

Szekspir lokuje scenę rozmowy między matką i synem w prywatnej komnacie królowej. Ponieważ nieustannie eksperymentuje w Hamlecie z konwencją szpiegowską, także ta scena - jedyna, w której Hamlet może spotkać się tylko „w cztery oczy” z matką - paradoksalnie zawiera ponadprogramowy element w postaci dodatkowej pary uszu, czyli Poloniusza. We wczesnonowożytnej Anglii prywatne pomieszczenia (closets) służyły kobietom nie tylko do wykonywania codziennych cielesnych rytuałów, jak na przykład ubieranie czy szycie, ale też do praktykowania czynności duchowych, takich jak modlitwa. Dla królowej było to miejsce szczególne, miejsce odosobnienia, dokąd tylko zaproszeni powinni mieć wstęp. Hamlet dostaje takie zaproszenie od Gertrudy, przekazane przez Rosencrantaza: „Życzy sobie pomówić z wami w swym gabinecie, / Zanim pójdzie spać" (3.2.598-599) oraz drugie - przez Poloniusza: „Wasza książęca mość, królowa chce z wami pogadać, i to zaraz" (3.2.648-649). Królowa sygnalizuje, że pragnie być wysłuchana przez syna, a tym samym Hamlet przygotowuje się do oddziaływania na nią poprzez percepcję słuchową:

Będę przemawiał do niej sztyletami,
Lecz nie użyję ich, niech w tym wypadku
W obłudzie język pławi się i dusza:
Niech język ja piętnuje jak najsrożej,
Pieczęci na tym dusza nie przyłoży (3.3.674-678).

Szekspir wykreował tę scenę na podobieństwo rozmowy między surowym i dociekliwym spowiednikiem a grzesznikiem, przy czym to Hamlet wciela się w rolę spowiadającego księdza, traktując matkę niczym potrzebującą wyznania swych występków grzesznicę. W scenie tej autor prezentuje - na zasadzie konfrontacji - kobiece i męskie zmysły.

Pierwsze słowa Hamleta, zaraz po wtargnięciu do komnaty królowej, brzmią: „I o cóż idzie, matko?” (3.4.811). Ustanawiają one relację pomiędzy pytającym, czy raczej przesłuchującym Hamletem a spowiadającą się królową. Gertruda od razu wyjaśnia powód wezwania syna na rozmowę: „Ciężko, Hamlecie, obraziłeś swego ojca” (3.4.812), lecz syn, parodiując jej wypowiedź, stwierdza: „Ciężkoście, matko, obrazili mego ojca” (3.4.813). Dobitna aluzja Hamleta zapowiada poruszenie długo pomijanego milczeniem tematu. Syn-spowiednik, przywołując krzyż święty, będący przecież atrybutem duchownego, przypomina matce, że jest żoną: „Brata swojego męża” (3.4.819). W kolejnych słowach Hamlet staje się coraz bardziej agresywny: 
No, no, no, siadajcie!

Kroku wam zrobić nie pozwolę, póki

Przed oczy nie postawię wam zwierciadła,

Co wam pokaże duszy waszej głębie (3.4.822-825).

Przywołując akt przyglądania się sobie w lustrze, Szekspir porusza wczesnonowożytne problemy z rozdzieleniem duszy od ciała, a tym samym tematykę zaklasyfikowania zmysłów do jednej ze sfer: cielesnej bądź duchowej. Można zinterpretować powyższe reprezentacje wzroku w kategoriach zasygnalizowanego przez dramaturga przejścia od przedkartezjańskiego pojmowania zmysłów ku odcieleśnionej koncepcji zmysłów. Chodzi tu o akt introspekcji, a więc zagłębienia się w samego siebie, spojrzenia skierowanego ku wnętrzu, wejrzenia w siebie „oczami duszy”. Jak podaje McDermott:

\begin{abstract}
Hamlet rozpoznaje w matce postać reagującą na bodźce wzrokowe, więc łączy werbalny atak [...] z wizualnym (rysowanie dla niej portretów). Traktując na równi introspekcję z bystrością wzroku, Hamlet wystawia „zwierciadło”, w którym jego matki „duszy głębie” ulegają powiększeniu, po to, by się im przyjrzeć („Perceiving Shakespeare”).
\end{abstract}

Przestraszona taką wizją i zachowaniem Hamleta, królowa wzywa pomocy. Na naśladujący wołanie Gertrudy, wydobywający się zza arrasu krzyk: „Na pomoc, hej, na pomoc!” (3.4.827), Hamlet reaguje zapytaniem: „A cóż to, szczur?", licząc, że za kotarą ukrywa się król (3.4.828). Gwałtownym wbiciem sztyletu Hamlet likwiduje „źródło krzyku”, zabijając Poloniusza. Hamlet uśmierca pierwszą postać w sztuce, łącząc ją symbolicznie ze zmysłem, który najczęściej wykorzystywał w swoich praktykach szpiegowskich - ze zmysłem słuchu. Poloniusz ginie przez nieostrożność w trakcie jednej ze swych ulubionych czynności - podsłuchiwania.

Szekspir w końcu „dopuszcza sytuację”, w której Gertruda i Hamlet faktycznie pozostają sami. Warto zwrócić uwagę na tekstualną obecność Gertrudy w sztuce, o której pisze Rebeca Smith w artykule „A Heart Cleft in Twain: The Dilemma of Shakespeare's Gertrude" (1980). Postać Gertrudy pojawia się w dziewięciu z dwudziestu scen dramatu, przy czym królowa ani razu nie wygłasza monologu. Najdłuższa konwersacja to właśnie rozmowa z Hamletem w jej komnacie. Jest to scena wyjątkowa także ze względu na nieobecność Klaudiusza, którego Szekspir umieszcza we wszystkich pozostałych scenach w pobliżu Gertrudy. Królowa albo jest ukazana już w obecności męża, albo w sytuacji oczekiwania na jego przybycie. Taka strategia tekstualna może sugerować, że Gertruda jest pod ciągłym „percepcyjnym nadzorem”, czyli pod czujnym okiem Klaudiusza, lub - jak w omawianej scenie - częściowo pod kontrolą audialną szpiega Klaudiusza. Może to również sugerować zależność kobiety od sposobu postrzegania świata przedstawionego w sztuce przez jej męża. Syn, pragnąc przerwać owo uzależnienie, podejmuje swego rodzaju „walkę ze zmysłami” matki lub chęć ich okiełzania. 
Analizując genderowy sposób wypowiedzi, zastosowany przez Szekspira w dialogu pomiędzy Hamletem i Gertrudą, można dostrzec wyraźnie skrystalizowane pozycje, jakie zajmują obie postaci. Z obronnych wypowiedzi Gertrudy: „Cóż popełniłam, że twój język taki / Brutalny hałas śmie podnosić na mnie?” (3.4.848-849) oraz „O biada, cóż to jest za czyn, którego / Są echem takie piorunowe ryki?" (3.4.964-865) wynika, że jest zaskoczona agresywnymi stwierdzeniami syna. Matka próbuje przywołać syna do porządku, podkreślając napastliwy i oskarżycielski ton Hamleta. Szekspir ukazuje w tej scenie reprezentacje słuchu Gertrudy w kategoriach zmysłu, który rozpoznaje dźwięki, lecz „nie słyszy” sensu przekazu. Hamlet postanawia wykorzystać wizualny sposób komunikacji, dlatego pokazuje matce dwa portrety i zestawia je na zasadzie kontrastu:

\author{
Spójrz na te dwa obrazy, konterfekty \\ Dwóch braci. Jakiż wdzięk siadł na tej twarzy: \\ To Hiperiona pukle i samego \\ Jowisza czoło; Marsa wzrok, co grozi \\ I rozkazuje; gońca Merkurego \\ Postawa, gdy opuści się na wzgórze, \\ Co nieb całuje błękit; zbiór przymiotów, \\ I postać, którą, rzekłbyś, swą pieczęcią \\ Naznaczył każdy bóg, ażeby światu \\ Dać pewność, że ma choć jednego męża. \\ To był małżonek wasz. A patrzajcie dalej: \\ To jest małżonek wasz; to kłos zjedzony \\ Przez śnieć, sąsiedztwem swym zagrażający \\ Zdrowemu bratu. Czy wy macie oczy? \\ Czyż to możliwe, żeście porzucili \\ Pastwisko tej wspaniałej góry, aby \\ Na tym bagnisku tyć? Czy macie oczy? (3.4.867-882).
}

Hamlet podważa intelektualny wymiar percepcji wzrokowej Gertrudy, sugerując, że w sposób „nierozumowy”, a więc cielesny, odbiera ona rzeczywistość zmysłem wzroku. Podwójne pytanie o to, czy matka posiada oczy, jest z jednej strony, oceniające i obraźliwe, a z drugiej - „oświecające” Gertrudę. Szekspir poświęca znaczną część wypowiedzi mężczyzn (w tym, w omawianej scenie, kwestie Hamleta) na krytykę kobiecego sposobu postrzegania. W dalszej części wywodu książę wyraża dezaprobatę:

O, na pewno macie zmysły,

Bo macie ruch, lecz sparaliżowane

To zmysły, sq̨dzę. Aniby szaleństwo

Tak nigdy nie zbłądziło, ni rozsadek

Nie zostałby tak kornym niewolnikiem 
Obłędu, aby nie zachować sobie

Takiej cząsteczki władzy wybierania.

Jakiej by było dość przy tej różnicy.

I cóż za diabeł was tak zdołał podejść

Przy ślepej babce? Wzrok bez czucia, czucie

Bez wzroku, uszy pozbawione oczu

I rąk, sam węch bez żadnych innych zmysłów,

Czy choćby słaba cząstka prawdziwego

Jednego zmysłu zdolna nie była

Wpaść w takie ogłupienie (3.4.887-901).

Szekspir udobitnia tym fragmentem znaczenie zmysłów jako narzędzi poznania. Caldwell zwraca uwagę, że w powyższym cytacie chodzi raczej o wskazanie na

załamanie w zakresie normalnej współpracy pomiędzy zmysłami oraz władzami intelektu, które nimi rządzą; podział świadomości tak radykalny, że wszystkie władze fizyczne i mentalne mkną samodzielnie niczym cząsteczki po eksplozji. Każdy zmysł - i rozsądek, który powinien te zmysły wspierać - błądzi samotnie, niepowstrzymywany przez współdziałające władze, które powinny je kontrolować (1979: 151).

Pewność, z jaką Hamlet wygłasza swoją opinię, służy podważeniu punktu widzenia matki i nakłonieniu jej do przyjęcia odmiennej perspektywy. Skoro zgodnie z wczesnonowożytną teorią sensoryczną, rolą zmysłów było stanowienie pomostu między umysłem a ciałem, przynajmniej według koncepcji przedkartezjańskiej, to w tym miejscu sceny Szekspir akcentuje konieczność współpracy pomiędzy ciałem i duszą, właśnie dzięki zmysłom.

Autor poprzez postać Gertrudy uzmysławia, jak męski sposób postrzegania wpływa na kobiecy. Królową przytłaczają obrazy, które podsuwa jej wyobraźnia, dlatego zwraca się do swego syna-spowiednika: „O, zmilcz, Hamlecie! Ty me oczy zwracasz / W głąb duszy mej i takie widzę plamy, / Że nic ich czerni zatrzeć już nie zdoła" (3.4.911-913). Hamlet wydaje się uzyskać władzę nad percepcją wizualną matki, zwłaszcza gdy w następnych słowach królowa dodaje: „Przestań, przestań! / Twe słowa w uszy wchodzq jak sztylety” (3.4.917-918). W artykule „Hamlet and Protestant Aural Theater” Tiffany twierdzi, że królowa „widzi swój grzech, słysząc go” (2003: 87). Hamlet, oprócz wskazania na portrety, sprawnie posługuje się retoryką moralności, dzięki czemu udobitnia przekaz wizualny. Tiffany podkreśla, że język ma większy moralny autorytet i przewyższa swym oddziaływaniem bardziej zwodnicze obrazy wizualne. „Słuchowy wymiar” przekazu ma, jej zdaniem, moc moralnego oczyszczania (83).

Wykorzystanie słów niczym sztyletów, wbijających się w uszy, ukazuje kolejną reprezentację słuchu w kategoriach seksualnych. Ucho, będące wraż- 
liwym organem ciała, zostaje „spenetrowane” przez brutalnie wdzierające się do niego dźwięki. Można nawet w tym kontekście powiedzieć, że Hamlet, który działa w imieniu ojca, w sposób werbalny „dokonuje gwałtu” na narządzie słuchu Gertrudy. Wymierzając karę, książę, który działa za przyzwoleniem zmarłego władcy, „zaczyna ujawniać wcześniej trzymane w tajemnicy sekrety" (Kelley, 1999: 100). Zdobywa się na odkrycie przed Gertrudą prawdy o zabójstwie popełnionym przez Klaudiusza, a więc na przekazanie opowieści ducha.

Odkrycie tajemnicy poniekąd ponownie „przywołuje” ducha. Szekspir wprowadza napięcie narracyjne, które powoduje „zmaterializowanie” zjawy po raz kolejny. Duch powtórnie objawia się Hamletowi w sposób wizualny, ale jednocześnie oddziałuje kanałem słuchowym:

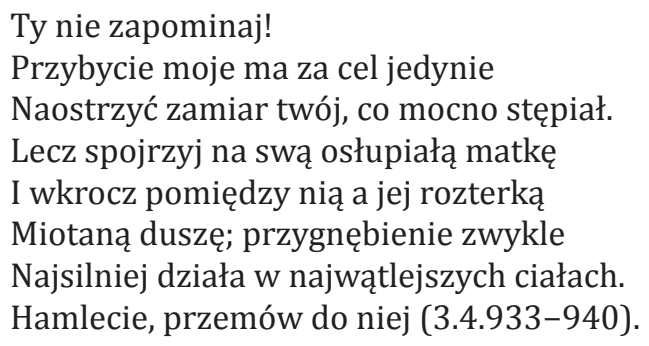

Taką strategią Szekspir ponownie pokazuje, jak „bawi się” zmysłami bohaterów w Hamlecie. Podobnie jak w scenach, w których jedni bohaterowie podpatrują i podsłuchują tych, którzy o tym nie wiedza, również zjawienie się ducha oznacza nieustanną „spektralną” obecność jakiegoś zwiadowcy albo szpiega. Duch nawiedza Hamleta oraz innych bohaterów w zupełnie inny sposób, a mianowicie poprzez bycie częścią plotki, legendy i przez opowiedzenie własnej historii synowi. W sensie metaforycznym ciągła możliwość bycia obserwowanym to „oko” Hamleta, zaś „ucho” dramatu stanowi nieustanne narażenie na podsłuchanie i rozpowszechnienie zasłyszanej historii w formie plotki.

Ważny jest fakt, że to właśnie komnata Gertrudy zostaje nawiedzona przez ducha. Można ten wybór miejsca potraktować w kategoriach wdarcia się do prywatnej przestrzeni królowej. Duch pozostaje jednak niewidoczny dla Gertrudy, co wprowadza dodatkowe zamieszanie w omawianej scenie. Warto podkreślić, że Szekspir wykreował postać ducha, która objawia się tylko wartownikom, Horacjowi i Hamletowi, zaś żadna z kobiet nie zostaje obdarzona tym przywilejem. Zaślepiona widokiem nowego męża królowa zapomina o dawnym, jakby wymazała go z pamięci, i traci też możliwość dojrzenia go w swojej komnacie. Z niedowierzaniem pyta Hamleta: 
Ach, jakże ty się czujesz,

Że w pustkę wlepiasz oczy i rozmawiasz

$\mathrm{Z}$ powietrzem bezcielesnym? Z twoich oczu

Szaleństwo patrzy (3.4.941-944).

Szekspir ponownie wyróżnia organ wzroku, ale kolejna reprezentacja percepcji wizualnej odnosi się do specyficznego sposobu widzenia. Jest to wyjście poza normalne postrzeganie rzeczywistości w stronę wizyjnego. Oczy Hamleta, dostrzegające zjawę, są dla „ślepej” Gertrudy oczami szaleńca. Książę daje do zrozumienia, że zjawa pozostaje przez jakiś czas w komnacie. Wodząc wzrokiem za duchem, który dla Gertrudy jest powietrzem, zostaje posądzony o halucynacje. Można też odczytać ten fragment w taki sposób, że Hamlet jest zaślepiony wizją, jaką roztoczył przed nim duch. Wokół siebie dostrzega jedynie zjawę, której wcześniejsza opowieść całkowicie skupia jego uwagę. Stąd też krytyczna postawa w stosunku do zdolności percepcyjnych Gertrudy i niedopuszczenie jej do głosu. Syn „zagłusza” matkę, zważając jedynie na przekaz usłyszany od ojca. Rozmowa kończy się zadaniem pokuty przez spowiednika. Hamlet zaleca matce, by wstrzymywała się od kontaktów seksualnych z Klaudiuszem i nie wyjawiła mu tajemnicy syna.

Po spotkaniu Gertruda przekazuje Klaudiuszowi informacje o tym, co zdarzyło się podczas wizyty Hamleta. Uznaje obłąkańcze zachowanie syna za powód niespodziewanego zabicia przez niego Poloniusza: „I przez majaki mózgu omamiony, / Zadaje śmierć dobremu staruszkowi, / Nie widząc go (4.1.12-14). Klaudiusz podejmuje decyzję o natychmiastowym wysłaniu Hamleta za granicę, przy czym zataja przed królową cel tego wyjazdu. Wysyła bratanka na śmierć, a listy z nakazem zgładzenia przekazuje jego towarzyszom podróży.

Podczas nieobecności Hamleta „opowieści nadal są rozpowszechniane, ale mają inny wydźwięk, manifestując cechy bardziej typowe dla plotki" (Kelley, 1999: 101). Wieści dotyczą głównie zabójstwa Poloniusza i nagłego wyjazdu księcia. Siłę oddziaływania słów wykorzystuje Klaudiusz, który napędza mechanizm rozchodzenia się spreparowanych informacji. Chcąc uniknąć zniesławienia lub oszczerstwa, które mogłyby być społeczną reakcją na dworskie wydarzenia, król postanawia:

Trzeba nam zgromadzić

Przyjaciół naszych co najrozsądniejszych

Powiemy im, co zamierzamy czynić

I co tu zaszło w tak fatalną chwilę.

Tak może potwarz - której szept, jak działo,

Dokładnie wymierzone w cel, przez świata

Średnicę całą rozsypuje swoje

Zatrute kule - chybi nas, a trafi

W powietrze, żadnej nie zadając rany (4.2.47-55). 
Decyzja o zmanipulowaniu społecznej, a więc kolektywnej percepcji audialnej po raz kolejny pokazuje, że Klaudiusz „wlewa truciznę” - zniekształcone informacje - do uszu dworzan. Postacią, którą w sztuce bezpośrednio dotykają nagłe zmiany w Elsynorze, jest Ofelia. Szekspir na przykładzie tej bohaterki pokazuje najbardziej tragiczne i gwałtowne zmiany dotykające zmysły w porównaniu z innymi postaciami dramatu. Kreuje Ofelię, która traci zmysły. Analiza sceny obłędu pozwala odnaleźć w niej reprezentacje percepcji wizualnej i audialnej o zupełnie innym charakterze niż pozostałe.

\section{Pomieszanie zmysłów, czyli szaleństwo Ofelii}

W tekście Hamleta „słyszalny” staje się głos szalonej kobiety, „uwidocznieniu" zaś ulega jej obłąkańczy wzrok. Wejrzenie w tekst dramatu stanowi próbę zinterpretowania stanu obłędu, niejako „stanięcia oko w oko" z reprezentacją archetypowego kobiecego szaleństwa w jego wymiarze sensorycznym. Uznanie szaleństwa za doświadczenie liminalne, a zarazem całkowicie angażujące zmysły, umożliwi odczytanie tego zjawiska w kategoriach odmiennej i odmienionej percepcji ludzkiej. Przekraczanie oraz wychodzenie zmysłami poza zwyczajny odbiór rzeczywistości, na przykładzie fikcyjnej postaci Ofelii, ma na celu przybliżenie szaleństwa w jego kulturowym wymiarze istnienia.

Wielowiekowa tradycja interpretacji szaleństwa Ofelii wskazuje na źródła tego zjawiska w nieoczekiwanej i traumatycznej śmierci ojca, wyjeździe brata oraz porzuceniu i odejściu Hamleta. Doszukiwanie się źródeł kobiecego obłąkania w utracie „obiektu miłości” ma na celu pozbawienie go „sprawstwa", a więc zrównanie z pasywnością i nonsensowną mową, tzw. czystym szaleństwem. Skoncentrowanie się jedynie na powiązaniu szaleństwa ze stratą ukochanych mężczyzn spłyca i powoduje „ujednowymiarowienie” tego stanu. Obłęd ma niejako wypełnić pustkę po odejściu najbliższych, będąc bezpośrednią reakcją opuszczonej dziewczyny.

Sięgnę jednak do świata zmysłów, by podjąć próbę bliższego przyjrzenia się fenomenowi postradania zmysłów. Otóż postrzeganie zmysłowe może być interpretowane dwojako. Po pierwsze, stanowi ono o ludzkim poznaniu w procesie odbioru, analizy i interpretacji zjawisk zewnętrznych. Po drugie - posiada aspekt dostarczania i generowania czysto emocjonalnego doświadczenia sensualnego. Jeśli zostanie zaburzony któryś z tych aspektów postrzegania (lub oba jednocześnie), wówczas funkcjonowanie aparatu percepcyjnego i postrzeganie zmysłowe - ujmowane metaforycznie - mogą ulec zakłóceniom. Jednostka, doświadczająca tych zmian, zostaje uznana za osobę, która doznaje pomieszania zmysłów. Warto tutaj przyjrzeć się zjawisku pomieszania, tracenia i odchodzenia od zmysłów na przykładzie Ofelii. 
Literatura dostarcza ciekawych „studiów przypadków”, zaś przypadek szalonej Ofelii można określić cytatem z Hamleta jako: „Zapis szaleństwa; dostrojenie myśli i wspomnień". W oryginale tekstu dramatu znajduje się następujący wers, będący jednocześnie wypowiedzią brata Ofelii, który komentuje obłąkańcze zachowanie dziewczyny: „A document in madness; thoughts and remembrance fitted" (4.5.172). W przekładzie Władysława Tarnawskiego znajdujemy takie tłumaczenie: „Obłęd poucza - pamięć i myśl chodzą razem” (4.5.453). Jak podaje Leslie C. Dunn, słowo „dokument” posiada także starsze znaczenie etymologiczne w języku angielskim, czyli „lekcja” bądź „przykład” (1994: 50). Dodatkowo, w renesansowym rozumieniu tego słowa, brat postrzega Ofelię jako obraz-symbol, wymagający słów, czyli komentarza, który zostaje dodany przez Laertesa i jednocześnie nadaje znaczenie jej szaleństwu (50).

Prób odczytania obłędu Ofelii było już tak wiele, że rację wydaje się mieć Carol Thomas Neely - badaczka związków między szaleństwem i gender - która w artykule „Documents in Madness”: Reading Madness and Gender in Shakespeare's Tragedies and Early Modern Culture zastanawia się, czy jakakolwiek próba mogła się w ogóle powieść jakiemukolwiek „rozumnemu” człowiekowi. Autorka pisze o trudnościach w interpretacji szaleństwa w następujący sposób:

\footnotetext{
Dokonując tego, osoba albo całkowicie odcina się od niego, albo czuje z nim związek, ale każdy z tych przypadków czyni tę osobę niezdolną do interpretacji. Zdrowe odczytanie szaleństwa to niezrozumienie istoty sprawy; szalone odczytywanie prowadzi do utraty własnego punktu widzenia (1991: 316).
}

Modyfikacja w translacji często przytaczanego przez krytyków i przywołanego powyżej cytatu z Hamleta polegałaby na wykorzystaniu wieloznaczności polskiego wyrazu „dokument” w języku angielskim. Jedna z definicji tego słowa wskazuje, że jest to „każda substancja materialna, na której przedstawione są ludzkie myśli za pomocą wszelkich konwencjonalnych znaków lub symboli”. Ofelia staje się ową „substancją materialną”, dosłownie zaś jej postać stanowi cielesny zapis obłędu.

Od początku XVII wieku kartezjańska res extensa funkcjonuje obok res cogitans, będąc jednocześnie podporządkowana tej ostatniej. Znaczącym przełożeniem tego podziału na sferę społeczną jest utożsamienie rzeczy rozciągłej, a więc substancji materialnej, z tym, co kobiece, zaś rzeczy myślącej, czyli substancji duchowej, z męskością. Kobieta jako ciało i mężczyzna jako umysł ustanawiają binarny podział w kulturze zachodniej. Jeśli wpleść w to rozgraniczenie zjawisko szaleństwa, okaże się, że także obłęd podlega kategoryzacji. Pozwala ona na kulturowe zaklasyfikowanie obłędu: bądź to zmaskulinizowane, bądź też sfeminizowane.

${ }^{9}$ Definicja pochodzi ze słownika www.ling.pl. 
Nim w scenie szaleństwa pojawi się jej główna bohaterka, Szekspir ukazuje sposób postrzegania Ofelii przez mieszkańców Elsynoru. I tak, przykładowo, Gertruda nie chce z nią rozmawiać, choć Horacjo przekonuje królową, że stan dziewczyny „łzy wyciska z oczu” (4.5.251). Horacjo wprowadza królową w percepcyjny świat Ofelii:

O ojcu dużo mówi,
A mówi też, że jak słyszała, świat jest
Niegodnych sztuczek pełen; potem chrząka
I w piersi się uderza; wypowiada
Niepewnym tonem rzeczy li w połowie
Dające się rozumieć; to, co mówi,
Nie znaczy nic, bezładna jednak mowa
Wysnuwać wnioski każe słuchaczom;
Zgadują więc i słowa jej łatają
Przystosowując je do swoich myśli,
A słowa te z jej mruganiami, głowy
Schylaniem i ruchami pozwalają
Domyślać się, że jest przyczyna, aby
Choć nie na pewno, bardzo złe mieć myśli;
Dobrze by było mówić z nią, bo łacno
Zajść mogą niebezpieczne przypuszczenia
W głowach, co skłonne są do takich wniosków (4.5.252-268).

W cytowanym fragmencie Szekspir nakierowuje uwagę na obłąkańcze zachowania Ofelii, wyróżniając aspekt audialny. Dziewczyna przede wszystkim staje się słyszalna, a jej mowa stanowi zagrożenie dla odbiorców. Wyłaniająca się reprezentacja odmiennego stanu percepcyjnego szczególnie akcentuje przekaz werbalny. Okazuje się, że plotki, które obiegły dwór w Elsynorze, musiały dotrzeć do Ofelii, w znaczący sposób wpływając na jej stan emocjonalny. Pomieszanie zmysłów u Ofelii skutkuje tworzeniem przez nią własnych narracji-plotek o powstałej, tragicznej sytuacji. Gertruda, która obawia się kolejnej wersji „prawdy” na swój temat, pragnie uniknąć rozmowy z Ofelią. Jednak ostatecznie decyduje się na wysłuchanie obłąkańczej mowy dziewczyny.

Ofelia w stanie obłędu nie daje się zagłuszyć; jej percepcja jest nie tylko odmienna, ale i odmieniona. Szekspir, dla zaakcentowania jej kondycji, inaczej portretuje głosowość tej postaci. Bohaterka oddziałuje na słuchaczy, układając własne piosenki, niejako wyśpiewując swoją historię. Jeśli dołączyć do tego wymiar wizualny obłąkania, można stwierdzić, że Ofelia jest najbardziej autentyczną „aktorką” spośród wszystkich bohaterów dramatu; jej wygląd jest naturalnie szalony, zaś słowa - rzeczywiście obłąkańcze, niemające nic wspólnego z przyjęciem na siebie przez Hamleta „zewnętrznego straszydła pozoru". 
Drugim istotnym zmysłem, zaangażowanym $\mathrm{w}$ proces postrzegania, jest wzrok. Kulturowe wytwarzanie sposobów patrzenia oraz oglądu świata, podobnie jak w przypadku wypowiadania/słuchania, uzależnione jest od płci. Również wywieranie wpływu na kobiecą percepcję wizualną jest manipulowaniem jej cielesnością. Oczy stanowią narzędzie kreowania ludzkiej perspektywy oraz źródło obrazów wewnętrznych. Przypadek szalonej Ofelii może wskazywać na zaburzenia w obrębie zmysłu wzroku, zarówno w jego wymiarze korporalnym, jako „oko ciała”, jak i w wymiarze mentalnym, pojmowanym jako „oko umysłu”. Podział ten funkcjonuje przede wszystkim na gruncie filozoficznym, jednak jego implikacje dla innych dziedzin nie mogą zostać pominięte. Gdyby transponować go na grunt rozważań antropologicznych, okaże się, że praktyki dotyczące patrzenia w znaczący sposób postrzeganie „okiem umysłu” przypisują mężczyznom, uprawniając ich do wszelkiego rodzaju spekulacji i czynności kontemplacyjnych. „Oko ciała” inaczej patrzy - głównie po to, żeby odbierać bodźce zewnętrze w celu orientacji w przestrzeni. Jest to zatem czysto biologiczna funkcja organu wzroku. Pozbawione sprawstwa, kobiece postrzeganie wzrokowe, głównie cielesne, stanowi kontrast dla męskiego, głębszego wymiaru widzenia. Takie rozgraniczenie tradycyjnie stanowiło próbę stereotypowego zaszeregowania kobiet i mężczyzn, którzy w odmienny sposób mieli wykorzystywać percepcję wzrokową. Jednak oczywiste jest to, że każda z płci robi użytek z fizycznej zdolności narządu wzroku, a także jego zdolności rejestrowania i tworzenia obrazów mentalnych oraz determinującego znaczenia wzroku dla konstruowania wiedzy o świecie.

Scena wybuchu szaleństwa Ofelii obnaża szczególny wymiar percepcji wizualnej oraz słuchowej, a mianowicie jej wymiar transgresyjny. Wymknięcie się kobiecego postrzegania zmysłowego spod kontroli sprowadza na duński dwór niebezpieczną, profetyczną istotę, która artykułując swoje wizje, napawa widzów i słuchaczy lękiem. Szekspir sportretował Ofelię zgodnie $\mathrm{z}$ renesansowymi wyobrażeniami o kobiecie szalonej. Za pomieszanie zmysłów miała odpowiadać choroba określana jako erotomania, która w XVII wieku dotykała głównie niespełnione seksualnie kobiety. W wielu wyśpiewywanych przez dziewczynę balladach pojawia się motyw porzuconej przez kochanka młodej kobiety, co mogło sugerować albo osobistą opowieść Ofelii o jej relacji z Hamletem, albo jej niezrealizowane pragnienia wobec mężczyzny. Marjorie Garber interpretuje piosenkę Ofelii, nawiązującą do dnia Świętego Walentego, jako „balladę o utraconym dziewictwie”. Melodyjna opowieść jest skonstruowana za pomocą języka obfitującego w aluzje seksualne albo wręcz „sprośnego”, co Garber uznaje za nietypowe i odbiegające od języka charakteryzującego tę „niewinną” postać (1981: 157).

Klaudiusz, który także uczestniczy w „spektaklu szaleństwa”, obawiając się następstw rozprzestrzeniania się kolejnych plotek o stanie Ofelii, zleca 
nadzorowanie jej i obserwację. Szekspir kreuje króla na interpretatora szaleństwa kolejnej postaci. Klaudiusz posługuje się sformułowaniem „trucizna ciężkiej zgryzoty" (4.5.331-332), a źródła obłędu doszukuje się w śmierci ojca Ofelii. Król obawia się, że „Lud, niby w lepkim i niezdrowym bagnie, / Topi się w rozmyślaniach oraz szeptach" (4.5.340-341), co grozi niebezpiecznym szerzeniem się plotek i utratą autorytetu władcy. Scena ta jest kulminacją niepokojów i obaw związanych z niekontrolowanym przeciekiem informacji, stanowiąc - obok motywu prawdy/fałszu - powracający wątek w Hamlecie. Szekspir ujmuje obawy ludzi okresu wszesnonowożytnego, dotyczące utraty kontroli nad wiadomościami, słowami Klaudiusza:

\author{
brat jej wrócił \\ Tajemnie z Francji, swoje podejrzenia \\ Podsyca, czarną się otulił chmurą, \\ A nie brak też bajarzy, co mu w uszach \\ Szczepiq zarazę jadowitych plotek \\ O śmierci ojca; przy czym nieświadomość \\ Nie mając danych, ani się zawaha \\ $Z$ ust do ust szerzyć oskarżenia przeciw \\ Osobie naszej (4.5.349-357).
}

Cytat mówi o Laertesie, na którego powrót Klaudiusz szykuje własną wersję wydarzeń. Do kraju powraca także Hamlet. Jedyną postacią, która wie o jego podróży do Anglii, jest Horacjo. Wie on również, że Hamlet wykrył spisek przeciwko sobie, dzięki czemu uniknął śmierci. Szekspir wykorzystuje po raz kolejny strategię opartą na generowaniu kilku intryg na raz oraz na zatajaniu informacji i wprowadzeniu dramatycznego zdarzenia, domagającego się wyjaśnień w formie narracji. Chodzi tu o śmierć Ofelii, która stanowi kolejną nieobecną w tekście scenę, a zaprezentowaną w postaci ekfrastycznego opisu jej utonięcia przez Gertrudę:

Jest wierzba pochylona nad strumykiem, O siwych liściach, co się odbijają W łyskliwej fali. Tam ona przyszła Z fantastycznymi girlandami jaskrów, Pokrzyw, stokroci i storczyków, które Nieokrzesany pasterz zwykł nazywać Mniej przyzwoicie, a wstydliwie dziewczę Zna jako palec trupa. Gdy się wspina, Aby wieńcami chwastów swych ozdabiać Zwieszone w dół konary, nagle gałąź Zdradziecka pęka, ona zaś po społu Z wydartym łąkom zielskiem spada na dół W szemrzącą łzami strugę. Rozpostarte 
Jej szaty przez czas jakiś ją trzymają

Na wierzchu jak syrenę, ona zasię

Starych melodii śpiewa wciąż urywki

Lub jak stworzenie urodzone w wodzie

I w niej żyjące. Ale to zbyt długo

Nie mogło trwać, wnet szaty, ociężałe

Napitkiem, przerywają wdzięczne trele

I pociągają biedną w namuliste

Objęcia śmierci (4.7.736-758).

Historia, jaką przedstawia Gertruda, jest stylizowana na opowieść „z drugiej ręki", stanowi zatem narrację narracji. Kobiecy sposób przekazywania tej tragicznej wieści podkreśla styl pełen obrazowej łagodności. Gertruda, która zjawia się jako posłaniec przynoszący złe wieści, przekazuje je Laertesowi i Klaudiuszowi w taki sposób, by wiadomość nie spowodowała następnego wybuchu niepokoju męża, a przede wszystkim szaleństwa Laertesa. W jej opowieści, wyrażonej upiększającym językiem wizualnym, Ofelia wyobrażona jest niczym „syrena” ${ }^{10}$. Po śmierci dziewczyny krajobraz Elsynoru odmienia się znacząco. Reprezentacje zmysłów poszczególnych bohaterów wskazują na przejście od wywiadowczej roli zmysłów ku pełnieniu przez nie funkcji „organów przeżycia”. Jak się bowiem okaże, to właśnie narządy zmysłu wzroku i słuchu w dużym stopniu zadecydują o dalszych losach bohaterów, dosłownie więc przesądzą o ich życiu lub śmierci.

\section{„Reszta jest milczeniem” - krwawy widok sceny finałowej}

Szekspir portretuje Hamleta, powracającego z morskiej wyprawy do Anglii, jako człowieka, który przywozi ze sobą kolejną historię do opowiedzenia. W listach do Horacja książę informuje go: „Powiem ci do ucha parę słów, od których oniemiejesz" (4.6.523-525). Stwierdzenie to brzmi analogicznie jak „ostrzeżenie”, jakie wypowiada w trakcie wcześniejszego spotkania z nim duch. W porównaniu z mającą na celu oddać prawdziwe zdarzenia opowieścią Hamleta, Klaudiusz tworzy kolejne wiarygodne dla słuchaczy, lecz jednocześnie kłamliwe narracje. Król wykorzystuje wyzwoloną w Laertesie chęć odwetu za śmierć siostry i ojca. Nie wtajemnicza Gertrudy, że planuje pozbyć się bratanka, wykorzystując do tego Laertesa. Mamiąc tego ostatniego, Klaudiusz znów odwołuje się do zmysłu słuchu: „Gdy uchem tego, który rzecz poj-

${ }^{10}$ Szerzej na temat Ofelii-syreny pisze Matthew A. Fike, przedstawiając liczne elżbietańskie kulturowe konotacje przypisywane syrenom w artykule "Gertrude's Mermaid Allusion”. Krystyna Kujawińska Courtney (red.), On Page and Stage: Shakespeare in Polish and World Culture, Kraków: Towarzystwo Autorów, 2000: 259-275. 
muje, / Słyszeliście, że ów, co był zabójcą / Waszego ojca, godził na me życie" (4.7.537-539). Wskazując winnego śmierci Poloniusza, król odwołuje się do uszu, którym przypisuje bezpośrednią zdolność pojmowania mowy.

W tym miejscu dramaturg ukazuje organ audialny w kategoriach narządu pojmowania, obdarzonego zdolnością intelektualnego rozumienia. Zatem strategia Szekspira, którą z powodzeniem stosuje w Hamlecie, polega na sterowaniu zmysłami bohaterów sztuki w taki sposób, by reprezentacje wzroku i słuchu zaskakiwały swą przynależnością bądź do ciała, bądź do umysłu, albo leżały na przecięciu obu; by wyjaśniały lub zaciemniały, lub pozostawiały w punkcie wyjścia; czy wreszcie, by pełniły aktywną albo pasywną rolę informatorów o świecie zewnętrznym.

Spiskujący Klaudiusz i Laertes przygotowują plan uśmiercenia Hamleta w trakcie pojedynku na szpady, przy czym broń Laertesa ma zostać namaszczona trucizną. Kolejna zasadzka na Hamleta jest zastawiona przez spiskujących ze sobą mężczyzn, których uszy metaforycznie przesiąknięte są jadem. W dosłownym zaś znaczeniu niewykrywalna przez żadne zmysły, toksyczna substancja, obecna na ostrzu szpady, przesądzi o losach bohaterów w scenie finałowej tragedii. Klaudiusz informuje Laertesa, że jeśli pierwsza trucizna nie zabije Hamleta, to z pewnością podany mu kielich z zatrutym winem doprowadzi do zamierzonego celu.

Końcowa intryga w dramacie Hamlet stanowi „ostatnią próbę” dla zmysłów bohaterów. W opinii Caldwella Hamlet jest cały czas zwodzony przez te percepcje, przez co nie potrafi zadecydować, kiedy zmysły mamią, a kiedy oddają prawdę. Badacz mówi nawet o tym, że „zmysły leżą na ziemi niczyjej pomiędzy duszą a światem zewnętrznym" (1979: 153), i trudno ocenić, czy zamieszanie w umyśle księcia powoduje „skaza w świecie, w którym żyje, czy skaza na jego własnej duszy" (153).

Pojedynek między Hamletem a Laertesem to w dużej mierze widowisko dla przybyłych dworzan. Jednak szermierczy spektakl zostaje uzupełniony komentarzami. Tym razem reżyserem, panującym nad przebiegiem przedstawienia, jest Klaudiusz. Podaje on do wiadomości przybyłych, że na Hamleta czeka specjalny kielich z winem oraz drogocenną perłą. Swoją przemową Klaudiusz naznacza zatruty napój przygotowany dla bratanka. Samo przyniesienie wina i ustawienie go na stole nie miałoby ceremonialnej wymowy, a być może pozostałby nawet niezauważone. Zmysły widzów i słuchaczy jeszcze raz zostają zwiedzione. Pojedynek przynosi jednak nieoczekiwany zwrot akcji, gdy królowa nieświadomie wypija zatrute wino, wznosząc toast: „Królowa pije do dna za twe powodzenie, Hamlecie" (5.2.670). Próba powstrzymania Gertrudy przez męża słowami: „Nie pij, / Gertrudo!” (5.2.671-672), nie odnosi skutku. Jest to pierwszy moment, gdy królowa nie spełnia polecenia Klaudiusza; moment, w którym ignoruje głos męża. „Zamknięcie uszu” na jego żądanie odblokowuje zmysły Gertrudy. Ostatnie słowa królowej są adre- 
sowane do syna: „Drogi / Hamlecie, napój, napój! Jam otruta!” (5.2.692-693) i przypieczętowują zmianę punktu widzenia tej kobiecej postaci.

Szekspir doprowadza akcję dramatu do momentu, w którym choć zobrazowanie akcji bardzo wiele mówi, jednak nie wystarcza do wyjaśnienia intrygi. Przekaz wizualny musi zostać uzupełniony wiadomościami docierającymi innym kanałem - drogą słuchową. Laertes, który trafia Hamleta ostrzem ,jadowitej" szpady, podejmuje się wyznania prawdy. W ostatnich słowach wyjawia, że niewinny z pozoru pojedynek, mający sprawdzić jedynie umiejętności szermierzy, w rzeczywistości jest zbrodniczym spiskiem:

Ta ohydna zasadzka przeciw mnie się obróciła:

Popatrzcie, leżę tu i już nie wstanę.

Otruta matka twa - już brak mi głosu -

To król, król winien (5.2.700-704).

Słowa wyzwalają w Hamlecie działanie - Klaudiusz zostaje zmuszony do wypicia toksycznego wina, co symbolicznie przypieczętowuje jego związek $\mathrm{z}$ rozsiewaniem jadu i wlewaniem trucizny do uszu (słuchaczy). Co więcej, usta Klaudiusza, czyli miejsce, skąd wydobywały się szkodliwe słowa, zostają raz na zawsze zamknięte.

Hamlet, wiedząc, że umiera, kieruje ostatnią prośbę do przyjaciela: „Jestem trup, Horacjo, / Ty żyjesz, zdaj więc nieświadomym ludziom / Relację o mnie i o mojej sprawie" (5.2.725-727). Meek podaje, że Hamlet, podobnie jak duch, pragnie „przetrwać” w opowieści (2009: 111). Z kolei Robert R. Wilson uważa, że historia Hamleta, którą Horacjo ma przekazać, będzie opowieścią rozbudowaną i bardzo złożoną, zawierającą także historię jego zmarłego ojca (1984: 39). Szekspir podkreśla znaczenie oczyszczających słów, które mogą zatrzymać bieg szkalujących plotek. Wyraża to, adresowana do Horacja, prośba Hamleta o przywrócenie mu dobrego imienia po śmierci. Hamlet przepowiada też polityczne losy Danii, oddając władzę w ręce królewicza norweskiego Fortynbrasa:

ja mu też oddaję

Swój konający głos; więc mu opowiedz,

Mniej więcej szczegółowo, te wypadki

Co sprowadziły - reszta jest milczeniem (5.2.747-750).

Szekspir finalizuje dramat spotkaniem i rozmową między Fortynbrasem i Horacjem.

Fortynbras w pierwszych słowach odnosi się do percepcji wizualnej: „Gdzież to zobaczę?" (5.2.754). Poza Horacjem nie ma świadków zobligowanych do przekazania właściwej i prawdziwej wersji wydarzeń. Autor dramatu po raz kolejny podkreśla konieczność współpracy obu zmysłów jako narzędzi 
poznania i zrozumienia. Sam widok może napędzać jedynie przypuszczenia, które od początku werbalizuje Fortynbras. Zastanawia się on, co jest przyczyną tak krwawego widoku. Misję opowiedzenia historii realizuje Horacjo:

\author{
Pozwólcie prawić nic nie wiedzącemu \\ Dotychczas światu, jak do tego przyszło. \\ Opowiem wam o krwawych mordach, sprzecznych \\ $\mathrm{Z}$ naturą, o karzącym ślepym trafie, \\ 0 przypadkowych śmiercionośnych ciosach, \\ O zgonach, które zrodził podstęp i omyłka, \\ A wreszcie o zamiarach nieudanych, \\ Co ugodziły w głowę swego twórcy. \\ To wszystko jestem zdolny najprawdziwiej \\ Wam opowiedzieć (5.2.774-783).
}

Horacjo zostaje wyznaczony przez Hamleta na kolejnego narratora, od którego percepcji dotychczasowych zdarzeń zależy kształt przyszłej opowieści. Jednak jego opowieść „poza sztuką” poprzedza znaczący i wymowny obraz - ceremonialne wyniesienie i wystawienie ciał zabitych na widok publiczny. Pożegnaniu towarzyszy też żołnierska muzyka oraz wybuchające salwy artyleryjskie. Takie wizualno-audialne pożegnanie pokazuje, że Szekspir „dokonuje pojednania” między tymi dwoma zmysłami, z których każdy ma odrębne zadanie do spełnienia.

Caldwell wyjaśnia, dlaczego Szekspir posłużył się odwołaniem do świata zmysłów w omawianej sztuce, podając, że:

Ostateczne posłużenie się zmysłami w Hamlecie służy zbudowaniu struktury, na której może opierać się podporządkowanie sztuki kwestiom wątpienia i niepewności oraz sugestii, że żadnej sugestii nie można ufać. Ze względu na to, że tworzą one trwały wzór, pomagają nadać sztuce kształt i uniemożliwiają niewiadomym pozbawienie jej [sztuki] struktury. Jednakże, ponieważ akty obserwowania i słuchania nigdy nie mogą być tak namacalne, tak całkowicie zauważone albo pojęte, jak odór zepsucia albo przenikliwa badawczość pytania, dlatego bardziej bezpośrednio przekazują niepewność wątpliwości. [Słuchanie i obserwowanie] w bardziej bezpośredni sposób zwalczają chaos; kontrolują i nadają formę niejasnościom, nie redukując ich obłudnie do porządku. Lecz nie podobna zobaczyć widzenia ani usłyszeć słyszenia. Traktujemy je jakby były realne, ale one pozostają na zawsze nie do końca uchwycone naszym postrzeganiem (179: 153).

Szekspir doprowadza do tragicznego finału Hamleta za pomocą nagromadzenia wyobrażeń związanych ze światem zmysłów. Dzięki technice błądzenia bohaterów, czytelnik także jest „wodzony za nos” i nieustannie zmuszany do wytężania własnych zdolności zmysłowych. Świat przedstawiony w Hamlecie jawi się jako ogromny labirynt, którego przejście, czyli obejrzenie/wysłuchanie całej sztuki, uświadomi, jakim złożonym i niedoskonałym mechanizmem są nasze zmysły. 
Rozdział 5

\section{Zmysły na ekranie: nowa zmysłowość Hamleta}

\section{Trzy razy „Hamlet” filmowy: 1990, 1996, 2000}

Apetyt na przeniesienie dramatu Hamlet na język filmowy rósł w miarę „kulturowego spożywania” tej sztuki przez poszczególnych reżyserów: od kina niemego po adaptacje wykorzystujące współczesne zdobycze kina postmodernistycznego. Apetyt na zmysłowość kulturową, tj. nadawanie znaczeń, tej sztuki z pewnością wspierany jest przez apetyt zmysłów na jej odczytanie (odbiorcy/reżysera). Na filmowe reprezentacje zmysłów w wybranych przeze mnie do analizy adaptacjach Hamleta z 1990, 1996 i 2000 roku składają się przede wszystkim sposoby, w jakie reżyserzy skonstruowali warstwę wizualną i audialną fabuły w poszczególnych filmowych reinterpretacjach. Chodzi tu o filmową strategię zobrazowania doświadczeń zmysłowych bohaterów w zakresie postrzegania wzrokiem i słuchem. To, w jaki sposób, gdzie, oraz w jakich konfiguracjach postaci dramatu wykorzystują postrzeganie zmysłami, składa się na poetykę zmysłów każdej z adaptacji. Istotny staje się zatem zarówno tekstualny zakres wypowiedzi poszczególnych bohaterów, jak i wizualne oddziaływanie pomiędzy nimi. Reżyserska metoda odpowiedniego umiejscowienia kamery oddaje punkt widzenia postaci oraz wzajemne postrzeganie pomiędzy bohaterami. Na siłę oddziaływań audialnych między nimi wpływa sterowanie ich głosem oraz treść i częstotliwość wypowiedzi (a czasem milcząca postawa).

W pierwszych słowach rozdziału poświęconego Hamletowi z 1990 roku, „Through the Looking Glass: Zeffirelli and the BBC”, Anthony B. Dawson wysuwa stwierdzenie, że „wizja sztuki Franca Zeffirelliego wydaje się określona przez akt spojrzenia. Kamera jest w ruchu, ciała są w ruchu, ale bardziej niż cokolwiek innego w tym filmie poruszają się oczy. Zachodzi nieustanna wymiana spojrzeń" ([podkreślenie Autora], 197). Badacz wylicza najistotniejsze ujęcia filmowe, wydobywające ów „akt spojrzenia”, jak gdyby możliwe było odczytanie z niego przeszłości, teraźniejszości, a nawet przyszłości:

Bez względu na to, czy jest to Ofelia, która odwzajemnia spojrzenie królowej podczas hałaśliwej uczty i na potwierdzenie tego powoli wznosi kielich; czy Poloniusz, który chwilę później przecina kierunek spojrzenia królowej; bądź Gertruda, zachęcająca wzrokiem 
Klaudiusza, by złagodził spór z Hamletem, bądź patrząca z góry na księcia, który zjawia się z aktorami; albo wreszcie sam Hamlet, wpatrujący się w Klaudiusza w scenie pogrzebowej albo rzucający spojrzenie i mrugający do królowej tuż przed tragicznym finałem pojedynku; i tak kamera [cały czas] pozostaje w gotowości na spojrzenia, 1995: 197).

Można zatem stwierdzić, że w swojej wersji Hamleta reżyser nadaje szczególne znaczenie zmysłowi wzroku. Tam, gdzie brakuje słów lub są one niepotrzebne, wymowne staje się ciało. W przypadku adaptacji Zeffirellego głównie „przemawiają” oczy różnych postaci dramatu, lecz najważniejszy pozostaje wzrok głównego obserwatora - Hamleta. Wcielający się w jego postać Mel Gibson wykorzystuje ten zmysł, „stając się” Hamletem, którego Ofelia określa mianem tego, który „wszystkie ścigał oczy” (3.1.184).

Pod względem zawartości tekstualnej Hamlet włoskiego reżysera stanowi wersję $\mathrm{w}$ istotny sposób okrojoną oraz przeorganizowaną w stosunku do akcji dramatu Szekspira. Z tego powodu akcja filmu wydaje się bardzo szybko nabierać rozpędu, wprowadzając czasem swego rodzaju niepokój, wynikający z pomijania pewnych partii tekstu i umieszczania ich $\mathrm{w}$ innym miejscu. Scenariusz oparty jest o pierwsze quarto, tradycyjnie uznawane za krótszą i „gorszą" wersję Hamleta (Bourus, 1995: 182). W artykule „Zeffirelli's Hamlet - Q1 in Performance” Kathleen Campbell wyraża opinię, że „[p]onieważ Hamlet Zeffirellego na wiele istotnych sposobów wykazuje podobieństwo do struktury pierwszego quarto, możemy rzucić okiem na sposób, w jaki tekst pierwszego quarto mógł być odgrywany na scenie" (1991: 7). Badaczka widzi podobieństwo w konstruowaniu charakterologicznie nieskomplikowanych postaci i wartkiej akcji (8).

O zaadaptowaniu Hamleta do potrzeb masowego odbiorcy pisze Magdalena Cieślak w artykule „Popularising Shakespeare - Franco Zeffirelli's Hamlet". Autorka uznaje, że reżyser musiał manipulować tekstem Szekspira, by dostosować go do filmowych oczekiwań potencjalnego widza, dla którego maksymalny czas trwania filmu wynosi dwie godziny, a najbardziej interesującym gatunkiem jest film akcji (2002: 37). Z kolei Douglas Brode podaje, że w rezultacie Zeffirelli uzyskał produkcję, która posiada raczej naturalistyczną aniżeli symboliczną scenerię; dialogi między postaciami są „bezlitośnie skrócone", zaś aktorzy nie wypowiadają swoich kwestii tak, jakby recytowali poezję, lecz prozę (2000: 136).

Jeśli za dystynktywną cechę stylu filmowego w Hamlecie Zeffirellego uznać spojrzenie, to elementem wyróżniającym filmową metodę Branagha jest stosowanie „odbicia”. Jak podaje Samuel Crowl, autor pracy The Films of Kenneth Branagh: „Obraz Hamleta uwięzionego we własnym odbiciu, dosłownie i przenośnie, stanowi najbardziej zdumiewające połączenie tekstu i metody [reżyserowania]" (2006: 142). Tropiąc motyw odbijających powierzchni, wysyłających refleksy bardziej lub mniej przypadkowo, Crowl natrafia u Branagha na zwodnicze zwierciadła: 
Lustrzane drzwi odbijają i zwiększają licznie występujące w sztuce lustrzane odbicia, począwszy od Ofelii „obyczajów zwierciadła”, po „podawanie niejako zwierciadła naturze”, które Hamlet traktuje jako sedno sztuki aktorskiej, oraz „zwierciadło”, w które pragnie się przemienić, by pokazać Gertrudzie jej „duszy głębie” (142).

Za każdym refleksem kryje się wspomnienie, niejednokrtotnie obciążające sumienie i niewygodną prawdę dla spoglądającej w lustro oraz zaglądającej w głąb siebie postaci.

O wymownym zastosowaniu w Hamlecie luster i zjawiska odzwierciedlania u Branagha wspomina też autorka Shakespeare From Stage to Screen (2004), Sarah Hatchuel, która dochodzi do wniosku, że bohaterowie stają się dla siebie odbiciami (26), niejako stają „twarzą w twarz” z sobą-innym. Najczęściej wyzwanie to podejmuje odgrywający rolę Hamleta Kenneth Branagh. Autorka pisze o „dwustronnych lustrach”, które nie tylko dosłownie są w wielu miejscach zainstalowane na dworze elsynorskim, lecz także ich działanie okazuje się dwustronne. W opinii Hatchuel: „Z jednej strony odbijają obraz, który ktoś spodziewa się zobaczyć, z drugiej zaś - nikt nie może przejrzeć tajemnic, które za sobą kryją" (26). Zatem wykorzystana przez Branagha metoda „odbijania” również odsyła do zmysłu wzroku. „Lustrami” są przedmioty, ale stają się nimi także postacie dramatu. Oczy służą więc do zaglądania w różne zwierciadła, których nie brak w adaptacji Branagha. Reżyser rozszerza ciągle powtarzający się gest spoglądania z wersji Zeffirellego o dodatkowy element, pogłębiający to spojrzenie, lustrzane odbicie. Przyjęcie takiej perspektywy przez Branagha to zapewne forma „wejścia w dialog” $\mathrm{z}$ poprzednimi adaptacjami - $\mathrm{w}$ tym niezwykle dobitnie - $\mathrm{z}$ filmową wersją Hamleta z 1990 roku.

Hamlet Branagha pod wieloma względami kontrastuje z wizją Zeffirellego. Jednym z odmiennych aspektów jest tekstualny wybór Branagha, czyli źródło scenariusza, wskazujące na połączenie drugiego quarto z pierwszym folio. Reżyser w ten sposób pozbawił się - zdaniem Hatchuel - możliwości wyeksponowania tych wątków, które można uwypuklić, kosztem skrócenia całości (2004: 144). Badaczka sądzi, że reżyser znalazł inną strategię filmową, mianowicie jego wybór padł na „rozwinięcie wszystkich fragmentów narracyjnych przez wykorzystanie retrospekcji i równoległych historii" (144). Łączenie kilku punktów widzenia na raz daje z kolei możliwość rozbudowania postaci pod względem osobowościowym. W adaptacji Branagha tekst dramatu zostaje zilustrowany przez odpowiadające mu obrazy filmowe, co według Hatchuel, powoduje niemalże jednoczesną zgodność pomiędzy przekazem werbalnym i wizualnym (2004: 25). Strategia adaptacyjna Zeffirellego nie zakłada takiego obrazowania warstwy tekstualnej. Raczej jego, okrojona pod względem werbalnym, adaptacja, z mnożącymi się transpozycjami, sprawia, że działania i słowa postaci nie nakładają się na siebie. W pewnym sensie 
akcja zastępuje słowa lub odwodzi od wypowiadanych słów, lecz ich brak rekompensuje wizualna strona przekazu filmowego. Russel Jackson wspomina w pracy The Cambridge Companion to Shakespeare on Film o wykreowaniu przez Zeffirellego „wizualnych korelatów słów” (2007: 224).

Trzecia omawiana w pracy adaptacja - Almereydy, traktuje obrazy w kategoriach „rozciągnięcia” słów. Pojawiają się obrazowe przedłużenia tekstu, niejednokrotnie bardziej wyraziste niż przekaz werbalny, a czasem bywa tak, że obraz wyprzedza to, co będzie wypowiedziane. Na poziomie tekstualnym Hamlet Almereydy nie bazuje na żadnej z wersji dramatu w sposób jednorodny i odrzuca ideę „właściwej” sztuki, którą należałoby sfilmować jako pełnotekstową. Jego adaptacja stanowi raczej składankę, skonstruowaną z połączenia tekstów różnych Hamletów oraz całego szeregu cytatów z innych źródeł, jak na przykład fragmentów z filmu Kruk II (1996) w reżyserii Tima Popa. W artykule „A »Harsh World« of Soundbite Shakespeare: Michael Almereyda's Hamlet (2000)” Elsie Walker pisze, że „koncepcja »dostępu« do »całego« tekstu zostaje w filmie Almereydy sproblematyzowana: po pierwsze, ponieważ film jest wyraźnie intertekstualny oraz po drugie - ze względu na swój fragmentaryczny styl" (2001: 334). Ten Hamlet w bezpośredni sposób eksponuje koncepcję intertekstualności, wchodząc w otwarty dialog z poprzednimi wersjami.

Gdyby - jak w przypadku poprzednich adaptacji - wyodrębnić powracający motyw w adaptacji Hamleta z 2000 roku, to będzie nim nieustannie „rejestrujące oko" technologiczne. Nagrywanie, zapisywanie i inne formy podglądu składają się na listę niestrudzenie pracujących „elektronicznych oczu”, które wymienia Peter Holland, autor Shakespeare, Memory and Performance (2006). Badacz - którego obszerne fragmenty pracy przytaczam poniżej - opisuje wybrane sceny w filmie, istotne z punktu widzenia ekspozycji sprzętów lub przyrządów mających wpływ na postrzeganie wizualne:

Film rozpoczyna się od video-pamiętnika Hamleta [...] Widać Hamleta rejestrującego inauguracyjną mowę Klaudiusza (w trakcie konferencji prasowej z dużą liczbą żarówek i mikrofonów) na jego podręcznej kamerze PXL 2000 Pixel oraz na monitorze. [...] Najpierw na monitorze bezpieczeństwa widać ducha zamkniętego $\mathrm{w}$ windzie, a potem scena $\mathrm{z}$ handlarzem ryb (the fishmonger) pokazana jest przez obiektyw kamery bezpieczeństwa. Ofelia robi zarówno trzydziestopięciomilimetrowe zdjęcia oraz zdjęcia Polaroid. Widać, jak robi zdjęcia (podczas pożegnania Poloniusza z Laertesem) i wywołuje je w ciemni, czekając na Hamleta [...] (288).

Holland wychwytuje filmowe obrazy współczesnych narzędzi technologicznych, uznawanych za przedłużenie organu wzroku. Wspomina o urządzeniach elektronicznych, choć niekoniecznie są to nowinki technologiczne, jak w przypadku kamery video czy analogowego aparatu fotograficznego, którymi posługują się bohaterowie. Uwagę Hollanda przykuwają także urzadzenia na stale wmontowane w pejzaż Nowego Yorku. Należą do nich wyposażenia wnętrz róznych obiektów np. hotelu, pokoju Hamleta czy nawet pojazdów: 
Telewizor gra w tle - pokazując coś wybuchającego i płonącego - podczas sceny spotkania Hamleta z duchem, a w trakcie sceny spowiedzi Klaudiusz w swojej limuzynie ogląda w telewizji Billa Clintona. [...] Klaudiusz komunikuje się z Rosencrantzem i Guildensternem głównie przez telefon [...]. Hamlet używa telefonu na żetony w piwnicy hotelu Elsynor [...]. Poloniusz „okablowuje” Ofelię mikrofonami przed spotkaniem z Hamletem [...] Po wykryciu tego przez Hamleta Ofelia odsłuchuje na sekretarce zarzucane jej oszczerstwa. „Pułapka na myszy” Hamleta to film video [...]. Hamlet kradnie dyskietkę, którą Rosencrantz i Guildenstern mają dostarczyć królowi Anglii i zmienia jej zawartość za pomocą swojego laptopa [...]. Hamlet wysyła Klaudiuszowi faks, zawiadamiający o jego powrocie do Danii, a Klaudiusz przefaksowuje do Hamleta zaproszenie na pojedynek z Laertesem. Pojedynek jest sędziowany elektronicznie, a gdy Hamlet umiera, widzimy ziarnisty, biało-czarny pikselowy obraz, odtwarzający różne obrazy filmowe, z przebitkami, które pokazują „żywy” obraz oczu Hamleta (288).

Almereyda w zupełnie inny - technologiczny, a przez to czasem też instrumentalny - sposób odwołuje się do percepcji wizualnej. W porównaniu z Zeffirellim, u którego dominuje niezapośredniczone przez żadne medium spojrzenie, oraz z Branaghiem, w którego adaptacji pojawia się wzrok wpatrzony w różnego rodzaju lustra - Almereyda stosuje najbardziej rozbudowaną formę wizualną, czyli oko obiektywu. W ocenie Marka Thorntona Burnetta wersja Almereydy udowadnia, że „nagrywanie filmów i filmów video dostarcza środków do napisania osobistego scenariusza” (Writing Shakespeare”, 2006: 189). Jest to zwłaszcza widoczne w momentach, gdy reżyserska „kamera wielokrotnie zatrzymuje się na autorskich oczach Hamleta" (189), w którego rolę wciela się Ethan Hawke.

Powyższe zestawienia pokazują, że każdy z reżyserów adaptacji Hamleta posługuje się odmienną strategią, wykorzystującą inne wersje dramatu. $\mathrm{Z}$ tego powodu w trzech omawianych adaptacjach wykształca się różnorodna relacja pomiędzy tekstem a obrazem. Dla dalszej analizy najistotniejsze jest jednak to, w jaki sposób każdy z filmów ukazuje reprezentacje zmysłów. Filmowe obrazowanie zmysłu wzroku i słuchu opiera się bowiem na połączeniu wyobrażeń oddających wizualne doznania postaci z doświadczeniami audialnymi. Dlatego to, co w filmie stanowi reprezentację zmysłu, jest niesprowadzalne do literackiego reprezentowania. Reprezentacja $\mathrm{w}$ filmie będzie zatem rozpatrywana pod kątem współdziałania między poziomem audialnym i wizualnym, rozumianym jako oddziaływania między ekranowymi bohaterami w świecie przedstawionym, oraz sposoby ukazania tego świata przez reżysera. Podobnie jak u Szekspira, tyle że za pomocą innych środków, w adaptacjach Hamleta można wyróżnić charakterystyczny styl, tym razem reżyserski, i strategię filmową, składające się na swego rodzaju filmową „poetykę zmysłów". 


\section{Pierwsze ujęcia a pierwsze wrażenia zmysłowe bohaterów i widzów}

Początkowa scena dramatu Hamlet w zasadniczy sposób kształtuje jego atmosferę sensoryczną. W filmie taką rolę pełni scena, ukazująca otoczenie pod kątem wizualno-audialnym, więc takie ujęcie, którym reżyser dokonuje „pierwszej odsłony” dzieła. Zeffirelli zrezygnował ze sceny pierwszej aktu pierwszego, w tym ze słynnego Szekspirowskiego pytania „Kto tam?”. Zamiast tego zaproponował własne rozwiązanie kwestii zainicjowania fabuły filmowej. Wycięcie przez niego sceny pierwszej i przejście do drugiej skutkuje przeorganizowaniem tej ostatniej i rozmieszczeniem jej elementów pośród odseparowanych od siebie scenerii (Lupton; Reinhard, 1993: 83). Zeffirelli otwiera Hamleta ujęciem murów zamku elsynorskiego: oddalony widok zamku na skarpie zmienia się stopniowo w zbliżenia jego murów, na których stoją strażnicy. Następnie przez dziedziniec, wypełniony poddanymi czekającymi na ceremonię żałobną, kamera prowadzi do krypty i sceny pogrzebu króla Hamleta. Reżyser wprowadza nieobecny u Szekspira wątek pochowania zmarłego władcy.

W pracy Shakespeare at the Cineplex: Kenneth Branagh Era Samuel Crowl określa zachowanie bohaterów w trakcie pożegnania dawnego władcy jako pantomimę oraz szloch (2003: 50). Co ciekawe, pierwszym słyszalnym głosem w filmie jest głos szlochającej Gertrudy (Glenn Close), pochylonej nad rozwartą w krypcie trumną. $Z$ jednej strony może to być zachowanie bardzo teatralne, mogące wzbudzić podejrzenia, z drugiej zaś - przejaw faktycznej rozpaczy i smutku. Wpływ lamentującej Gertrudy na percepcję słuchową zebranych staje się widoczny w reakcjach, które pojawiają się na ich twarzach. „Na pierwszy rzut oka” wszyscy wydają się pogrążeni w zadumie, ale dopiero zbliżenia ich twarzy pozwalają na interpretację ukrywających się emocji.

Królowa ubrana jest w żałobny strój; twarz ma przesłoniętą woalką. Zeffirelli daje do zrozumienia, choćby przez odpowiednie operowanie kamerą, że wszyscy obserwują Gertrudę. Na przykład na chwilę pokazuje przypatrującego się jej Klaudiusza (Alan Bates), a dopiero potem przechodzi z powrotem do Gertrudy, która podnosi do góry woalkę i odsłania oczy. Królowa skupia uwagę na zmarłym mężu. Można odnieść wrażenie, że zamknięte i,,śpiące" oczy nieżyjącego władcy w każdej chwili mogą się otworzyći wprawić zebranych w osłupienie. Z kolei wypełnione łzami oczy Gertrudy kontrastują z zimnym i zazdrosnym spojrzeniem Klaudiusza, który z dystansem obserwuje pożegnanie małżonków. Filmowe reprezentacje organu wzroku wskazują na relacje panujące między bohaterami i zapowiadają wszechobecny nastrój podejrzliwości, wieloznaczności oraz szpiegowania.

Nim kamera pokaże twarz Hamleta, najpierw widać zbliżenie jego dłoni, która sięga po ziemię, by następnie posypać nią zmarłego. Gdy Klaudiusz 
zaczyna przemawiać do odwróconego do niego bokiem, z twarzą ukrytą pod kapturem - Hamleta, ten nie zwraca się w jego stronę, lecz podchodzi do matki. Zasłonięta kapturem głowa bohatera może symbolicznie wskazywać na jego niechęć do kontaktu werbalnego oraz wzrokowego z otoczeniem. Kwestia wypowiedziana przez Klaudiusza to z kolei pierwsze słowa scenariusza:

\author{
Niechaj świat to widzi, \\ Żeście najbliższy tronu i że ni mniej \\ Szlachetną miłość żywim dla was, niźli \\ Najczulszy ojciec żywić zwykł dla syna (1.2.341-344).
}

Nieprzypadkowo zapewne Zeffirelli kreuje wypowiedź Klaudiusza na pierwszą próbę zmanipulowania percepcją audialną Hamleta i innych słuchaczy. Po zamknięciu trumny Klaudiusz kładzie na niej miecz zwrócony w stronę Gertrudy. Wtedy dochodzi też do niepokojącej wymiany spojrzeń między Klaudiuszem i Gertrudą, która na chwilę przerywa swój lament. Zauważa to Hamlet i bez komentarza opuszcza kryptę, wypełnioną dźwiękami szlochającej królowej. Poprzez takie wprowadzenie do Hamleta reżyser sygnalizuje, że jego strategia adaptacyjna będzie koncentrować się wokół uwypuklenia reprezentacji zmysłu wzroku, w większości przypadków zastępujących reprezentacje słuchu.

Branagh, realizujący pełnotekstową wersję dramatu, rozpoczyna adaptację od zbliżonego ujęcia napisu "HAMLET”, wyrytego w kamiennej płycie. W pracy William Shakespeare's „Hamlet”: A Routledge Study Guide and Sourcebook Sean McEavoy stoi na stanowisku, że „[f]ilm rozpoczyna się od uderzającego uwypuklenia tekstu" (2006: 109). Kamera, która przesuwa się wzdłuż napisu, odsłania oddalony pałac w Elsynorze. Jak się okaże, napis stanowi część pomnika przedstawiającego króla Hamleta. Jego posągowa podobizna będzie łącznikiem między światem żywych i umarłych, bo właśnie ten posąg ożyje, by nawiedzić strażników zamku. Branagh przedstawia króla Hamleta jako ożywiony posąg, jeszcze zanim zjawi się on ponownie przed wartownikami. Reżyser pokazuje, jak ręka posągu chwyta za miecz w tym samym momencie, gdy przybywający na zmianę straży Bernardo rzuca się z bronią na stojącego na warcie Franciszka i przewraca go na ziemię. Wywołuje to zaskakujący efekt nałożenia na siebie dźwięków. Branagh stosuje wiele niespodzianych rozwiązań filmowych, by czterogodzinna ekranizacja, z pełnym tekstem sztuki, była atrakcyjna pod względem wizualnym i audialnym.

Reżyser ukazuje pełnienie warty jako wydarzenie, które najpierw angażuje percepcję wzrokową, a następnie - po rozpoczęciu rozmowy między Bernardem, Marcellusem i Horacjem - także słuchową. To wymiana zdań między trzema mężczyznami faktycznie wprowadza w fabułę filmu. Bernardo zaczyna opowiadać o zjawieniu się ducha, po czym następuje jego fak- 
tyczne przybycie. Bohaterowie w popłochu zaczynają uciekać przed widziadłem. Zjawa jest ciemną postacią, ukazaną na tle jaśniejszego nocnego nieba w taki sposób, że początkowo wartownicy nie widzą nawet jej twarzy. Duch odsłania swoje oblicze podczas powtórnego ukazania się. Spogląda na postaci z góry, co nie tylko służy podkreśleniu jego pozycji, ale także sugeruje jego „boską perspektywę”, czyli punkt widzenia aktywnego obserwatora, który z oddali nieprzerwanie monitoruje wydarzenia w świecie ludzi.

Branagh, który podąża za Szekspirowską fabułą dramatu, dwukrotnie w pierwszej scenie ukazuje nawiedzenie wartowników przez posągowego ducha. Zjawa odgrywa niemy spektakl, który inspiruje strażników i Horacja do snucia przypuszczeń, a także do tworzenia opowieści. Oddziałuje na percepcję wzrokową uczestników spektaklu, co sprawia, że zaczynają oni budować narrację. Szczególnie poruszony wydaje się Horacjo, którego stosunek do istnienia ducha był dotąd sceptyczny. W omawianej scenie Branagh wprowadza filmowe reprezentacje zmysłu wzroku i słuchu, które oddają percepcyjne zdumienie, a nawet wstrząs, jakiego doznaje Horacjo. Ponadto zauważalne staje się to, że reżyser zdecydował się na rozwinięcie wszystkich wątków dramatu, ponieważ oprócz dyskusji, sprowokowanej przybyciem ducha, postaci rozmawiają o sytuacji politycznej w Danii.

Scena inicjująca akcję Hamleta Branagha oddaje zarys jego reżyserskiej koncepcji adaptacji dramatu. Można powiedzieć, że Branagh kieruje się zasadą „stosowania ruchów do słów, a słów do ruchów”, którą Szekspir zawarł w Hamlecie $^{1}$. Reżyser jednocześnie pozwala zaistnieć słowom Szekspirowskiego dramatu, zaś akcję ilustruje obrazem filmowym. Znamienne jest to, że postaciami wprowadzającymi w akcję dramatu, tak jak u Szekspira, są męscy bohaterowie. W konsekwencji zarówno męska perspektywa, jak i męskie głosy, zdominują pozostające w mniejszości sensorycznej dwie bohaterki Hamleta.

W przeciwieństwie do Zeffirellego, który umieścił pierwszą scenę adaptacji w zamkniętym pomieszczeniu - krypcie, Branagh - zgodnie z Szekspirowską fabułą - lokuje ją w otwartej przestrzeni. Adaptacja Zeffirellego stylizowana jest od początku na dramat rodzinny, co następująco ujmuje Dawson: „To, co jest publiczne u Szekspira, staje się prywatne u Zeffirellego” (1995: 199). Postaci uwięzione w średniowiecznych murach zamku - tutaj bowiem reżyser umieszcza akcję Hamleta - są niemalże „skazane” na wzajemne spojrzenia. U Branagha, który osadza fabułę w dziewiętnastowiecznych realiach wiktoriańskiej Anglii, często powraca inny motyw. McEvoy określa go jako „odczucie, że rodziny królewskie nie mają życia prywatnego" (2006: 108). Reżyser udobitnia ów brak intymności przez rozmieszczenie w pałacowej przestrzeni mnóstwa luster. Bohaterowie tej adaptacji nieustannie zwracają swoje oczy ku odbijającym obrazy zwierciadłom. Natomiast Almereyda jesz-

\footnotetext{
${ }^{1}$ Jest to sparafrazowana przeze mnie porada Hamleta, skierowana do aktorów, która brzmi: „Stosujcie / ruchy do słów, a słowa do ruchów” (3.2.252-253).
} 
cze inaczej rozwiązuje kwestię umiejscowienia zdarzeń Hamleta. Wybiera przełom XX i XXI wieku oraz Nowy Jork jako miejsce akcji dramatu.

Pierwsze ujęcie filmowe Almereyda poświęca widokowi migających światłami drapaczy chmur w centrum Nowego Jorku, obserwowanych przez „kogoś” siedzącego w limuzynie i patrzącego przez okno umiejscowione w dachu samochodu. Można także odnieść wrażenie, że to budynki niczym ludzie „obserwują”, same pozostając „zdystansowane” - „przyglądające się światu z góry". Reżyser stosuje zabieg konstrukcyjny, który polega na usunięciu sceny pierwszej dramatu i zamiast niej - wprowadzeniu napisów objaśniających. Można się z nich dowiedzieć, że król i jednocześnie szef korporacji „Dania” zmarł, jego żona poślubiła młodszego brata władcy, a syn Hamlet domyśla się ukrytego spisku i intrygi. Wraz ze zniknięciem napisów znika obraz drapaczy chmur, a pojawia się postać mężczyzny w czapce, wysiadającego z limuzyny w centrum miasta. Zaraz po tym Almereyda nakierowuje kamerę na ogromne logo firmy „Dania”, które przypomina wielką, jasną źrenicę oka. Burnett tak komentuje ów symbol Danii: „to zarówno przesłona obiektywu, jak i rodzaj oka” (,»I see my father «", 2006: 38). Panoptyczne formy kontroli, którymi przepełniona jest produkcja milenijnego Hamleta, obecne są zarówno na ulicach, jak i wewnątrz budynków, a logo firmy jedynie uprzedza o wszechobecnych, anonimowych „oczach obiektywów”.

Reżyser przenosi dalszą część sceny początkowej z otwartej przestrzeni do pokoju w hotelu Elsynor. Tutaj ukazuje się ziarnisty, czarno-biały, nieco pozamazywany video-obraz twarzy mężczyzny (Hamleta), która wypełnia prawie cały ekran. Słychać też, jak bohater wypowiada kwestię z aktu drugiego, sceny drugiej dramatu Szekspirowskiego, zaczynającą się od słów: „W ostatnich czasach - ale nie wiem $\mathrm{z}$ jakiego / powodu - utraciłem dawną wesołość" (486-487). Almereyda już na samym wstępie dokonuje pocięcia tekstu dramatu i wykorzystuje jego fragment jako element przemyśleń bohatera, skierowanych - nie jak w sztuce - do Rosencrantza i Guildersterna, lecz adresowanych do siebie. Jak podaje William B. Worthen w pracy Shakespeare and the Force of Modern Performance (2003): „Hamlet ogląda obraz samego siebie, używając kamery cyfrowej do tego, by przypominać sobie i rozpamiętywać, przekształcając odtwarzanie monologu w chwilę alienującego solipsyzmu" (111).

Almereyda decyduje się odsłonić kondycję głównego bohatera już w pierwszej scenie, przez użycie do tego celu najbardziej znaczącego i „intymnego" dla Hamleta urządzenia, ale też paradoksalnie - najbardziej ekshibicjonistycznego, czyli kamery. Reżyser pokazuje, że Hamlet, wykorzystując percepcję wizualną, może nią manipulować przez nagrywanie własnych filmów i zastanawiać się, czym dla niego jest „kwintesencja prochu”. Oglądanie siebie na ekranie to nie tylko przyglądanie się własnemu wyglądowi, ale również wgląd w samego siebie. Zdaniem Agnieszki Rasmus, autorki artykułu 
„»I Could a Tale Unfold«: From Metatheatre to Metacinema: Films Within Films in Shakespeare on Screen", wizja Almereydy jest zdecydowanie od samego początku „zorientowana na Hamleta” (2001: 161), a często pojawiającym się wizualnym motywem są sfilmowane retrospekcje, związane z przeszłością bohatera. Istotnym elementem nagrań jest dźwięk, bez którego obraz byłby niekompletny. W tym sensie to właśnie warstwa językowa stanowi przedłużenie warstwy wizualnej. Hamlet nie tylko przygląda się sobie, ale również wsłuchuje się w siebie, odtwarzając własny głos z kasety.

Almereyda portretuje Hamleta jako postać, która sięga po zdobycze technologiczne po to, by stały się one bronią skierowaną przeciwko kulturze panoptyzmu, innymi słowy - by przeciwstawić się terrorowi nadzoru i podglądania. Hamlet występuje więc w roli buntownika, korzystającego z wytworów kultury, przeciwko której protestuje. W opinii Douglasa Laniera, autora artykułu „Shakecorp Noir”, u Almereydy zarysowuje się kontrast pomiędzy stechnicyzowanym krajobrazem świata przedstawionego a próbą wyrwania się spod jego kontroli przez Hamleta. Badacz mówi o manifestowanym sprzeciwie bohatera, który przejawia się w jego amatorskich praktykach filmowych (2002: 177). Można także powiedzieć, że Hamlet stawia opór swymi zmysłami wobec tego, co postrzega w ramach milenijnej kultury nadzoru.

Pierwsza scena adaptacji Almereydy w pewnym sensie nawiązuje do wątku ducha z dramatu Szekspira. Można powiedzieć, że „zjawą” jest obraz Hamleta, którego już „nie ma”; Hamlet, którego słowa i wizerunek zostały utrwalone na kasecie. Czarno-biały obraz dodatkowo wzmaga odczucie, że postać przemawiająca z monitora „odeszła”. Podobieństwo do ducha przejawia się też w tym, że Hamlet staje się poniekąd „zjawą”, zawieszoną między dwoma światami: realnym i wirtualnym. Samoobserwacja przy użyciu „elektronicznych oczu” staje się sposobem na przetrwanie w owym zawieszeniu. Według Thomasa Cartelli i Katherine Rowe, w porównaniu z innym Hamletami:

Jest to postać, która w przeciwieństwie do swojego imiennika, aż tak bardzo nie rozmyśla, ale wydaje się raczej za dużo patrzeć; postać, która nie żyje samotnie w swojej głowie, lecz w zapośredniczonym związku z rzeczywistością, dzięki zespołowi urządzeń do tworzenia obrazów ([podkreślenie autorek] 2007: 49).

Zestawiając Hamleta Alamereydy z filmowymi wizjami Zeffirellego i Branagha, należy stwierdzić, że bohaterowie tej adaptacji nie tylko mogą spoglądać, nie tylko mogą używać do tego różnego rodzaju „zwierciadeł”, ale także mogą owe spojrzenia i odbicia trwale zarejestrować, w dowolnym momencie zatrzymać, odtworzyć, czy też całkowicie cyfrowo zmodyfikować, a nawet skasować. 


\section{Różne wizje zjawy na ekranie}

W adaptacji Zeffirellego, podobnie jak w dramacie Szekspira (choć nieco inaczej pod względem rozwoju fabuły, gdyż z pewnym opóźnieniem w stosunku do „oryginału”), duch najpierw objawia się wartownikom i Horacjowi. Reżyser ukazuje to zdarzenie w formie opowieści adresowanej do Hamleta, z pominięciem filmowego zobrazowania. Historia zostaje zrelacjonowana w skrytości, z dala od hałasów uczty weselnej Klaudiusza i Gertrudy. Ciekawe, że atmosfera podglądania powoduje, iż Hamlet dodatkowo sprawdza, czy jest śledzony i podsłuchiwany. W końcu zjawa przybywa na zamkowe mury, na co Hamlet reaguje żywiołowym przemówieniem do niej. Zeffirelli ukazuje ojca Hamleta w stroju innym niż ten, w którym został pochowany; jego szata bardziej przypomina sutannę. Duch (grany przez Paula Scofielda) pojawia się i znika, wskazując dłonią Hamletowi, że chce, by za nim podążał. Zdaniem Dawsona:

W kontekście filmu, w którym patrzenie jest podstawowym gestem; filmu posługującego się tekstem, w którym szpiegowanie, obserwowanie oraz udawanie stanowią główny, powtarzający się motyw - takie triki ze znikaniem i pojawianiem się, z tym, co jest widziane, i jak to jest widziane, nabierają dodatkowego znaczenia (1995: 201).

Ostatecznie, w swoim pościgu za widmem, Hamlet zmuszony jest wspiąć się aż na szczyt murów obronnych zamku, by dopiero tam jego zmarły ojciec przemówił. W artykule „»A Palpable Hit«: Franco Zeffirelli's Hamlet (USA, 1990)” Chris Lawson tak interpretuje „poszukiwania” ducha w zamkowej przestrzeni:

Lekko oświetlone i słabo pobłyskujące widmo prowadzi Hamleta w stronę światła na końcu korytarza. Owo światło może reprezentować objawienie, które Stary Hamlet przekaże swojemu synowi, a dotyczy ono „ohydnego mordu, natury wszelkiej targającego prawo" (1997: 235).

Duch z wersji Zeffirellego oddziałuje najpierw na percepcję wizualną Hamleta, mamiąc swą obecnością i ulotnością, potem zaś skupia na sobie uwagę audialną bohatera. Filmowe reprezentacje zmysłu wzroku i słuchu w tej scenie wskazują na konieczność połączenia obrazowania z werbalizacją dla wyzwolenia w Hamlecie chęci zemsty. Nieuniknione staje się zatem „zaszczepienie" wizji morderstwa przez organ słuchowy.

Reżyser umieszcza dwie siedzące naprzeciwko siebie postacie w wieży zamkowej. Ojca od syna oddziela jedynie odległość „wyciągniętej ręki”, bo bohaterowie znajdują się na kamiennych, okrągłych ławach wieży. W trakcie przejmującej opowieści ducha Zeffirelli pokazuje kontrastujące zbliżenia twarzy obu postaci. Lawson twierdzi, że na postaci ducha nie odznacza się żadna gra światła, za to twarz Hamleta cały czas pozostaje w połowie oświe- 
tlona, a w połowie - w cieniu. Badacz interpretuje to jako dosłowne przyćmienie Hamleta wiadomością o przyczynie śmierci ojca (1997: 235). Zjawa podkreśla konieczność zachowania w tajemnicy szczegółów mających związek z miejscem, skąd przybywa, w tym mąk „ognistych”. Uwidacznia to gestem zasłonięcia oczu, porażonych niewysłowionym widokiem. Duch w swoim opowiadaniu odwołuje się do zatrutych przez Klaudiusza uszu (podnosi rękę w kierunku ucha) i wskazuje na konieczność pomszczenia morderstwa. Zeffirelli przedstawia w tej scenie dogłębnie poruszonego Hamleta, któremu opowieść i widok ojca wyciskają łzy z oczu. Ponieważ twórca ten rezygnuje z wizualizacji narracji, stąd w trakcie przekazywania opowieści najważniejsza staje się mowa ciała i reakcja słuchacza. Tuż przed odejściem zjawa zbliża się do Hamleta, jakby chciała dotknąć oburącz jego głowy albo ramion. W trakcie zbliżenia twarzy ojca Hamleta widać łzę, która spływa po jego policzku. Jest to dodatkowy wizualny bodziec, zwłaszcza jeśli w momencie pożegnania płacze dawny władca Danii. Zeffirelli pokazuje Hamleta z „rozpościerającymi się ramionami i zamkniętymi oczami, jakby spodziewał się czułego uścisku, by jednak [ostatecznie] przekonać się, że zjawa zniknęła" (236). Zatem ponownie reżyser stosuje trik „przybliżenia i oddalenia” ducha, by zaakcentować jego dwoistą, zawieszoną pomiędzy światami naturę.

Hamlet Zeffirellego to postać gwałtowna i uzewnętrzniająca emocje, bardziej porywcza niż główny bohater adaptacji Branagha - pełen manier i ogłady, powściągliwy żołnierz, czy też posępny i poszturchiwany przez Klaudiusza Hamlet Almereydy. Po odejściu ducha Hamlet Zeffirellego wydaje się od razu gotowy do działania, a jego postrzeganie silnie pobudzone. Obserwując ucztę weselną z murów zamku przez zakratowany otwór, chwyta za swój miecz, którym w trakcie wypowiadania monologu próbuje wypisać na kamieniach: „Że można się uśmiechać i uśmiechać, / A łotrem być" (1.5.914-915). Miecz nie stanowi więc tylko ozdoby jego pasa, lecz również widoczny symbol zemsty. Właśnie na miecz uniesiony do góry Horacjo wraz ze strażnikami przyrzekają o dotrzymaniu tajemnicy po tym, jak podziemny głos ducha nakazuje im milczenie. U Zeffirellego zjawa przybywa jako zjawisko wizualne, a odchodzi jako niewidoczny dla oczu, „odcieleśniony głos” (Lawson, 1997: 236). Hamlet zaś oznajmia, że jego zachowanie może być diametralnie różne od dotychczasowego; innymi słowy, zapowiada udawanie szaleństwa, czyli powodowanie odmiennych stanów percepcyjnych u siebie, jak i wywoływanie ich u innych. W Hamlecie Branagha duch przeistacza się z posągu w dawnego króla w pełnym uzbrojeniu. Zgodnie z koncepcją reżysera, skoro Dania jest pomyślana jako „militarystyczne państwo”, także duch zostaje wykreowany na „wojowniczą zjawę o kolosalnych rozmiarach” (Burnett, 2002: 92). Zjawa (w tej roli Brian Blessed) ponownie przybywa w to samo miejsce co poprzednio, czyli do bram pałacowych. Branagh rezygnuje z umieszczenia analizowanej sceny w granicach elsynorskiego pałacu. 
Hamlet, który już oczekuje na ducha, tuż po dostrzeżeniu go postanawia za nim pobiec. Branagh pokazuje, jak książę biegnie przed siebie, oddalając się od pałacu. Kamera oddaje „obłęd” owej gonitwy. W ujęciach „pościgu” za zjawą bohater biegnie za nadprzyrodzonymi dźwiękami nocy i eksplozjami pary wydobywającej się spod ziemi, ponieważ jest prowadzony przez postać przybywającą z innego świata. Miejsce, do którego dobiega, to całkowite odludzie, przypominające cmentarne pustkowie, dokąd nie zapędzają się śmiertelnicy. Jednak Hamlet dociera do tej samotni i nawołuje ducha, by do niego przemówił. Zjawa działa z zaskoczenia, chwytając Hamleta za szyję i przewracając go. Hamlet przywiera do drzewa i w skupieniu wsłuchuje się w niski i szepczący głos ducha. Branagh posługuje się techniką pokazania perspektywy ducha z wysoka, a postaci, ku którym zwraca wzrok, wyglądają przy nim mało okazale i „poddańczo”. W tej adaptacji zjawa oraz okoliczności jej przemowy nabierają cech nadprzyrodzonych: jej wzrok jest upiornie przeszywający, źrenice rozszerzone, zaś głos brzmi grobowo i hipnotyzująco. Dodatkowo w omawianej scenie pojawiają się elementy nadnaturalne, takie jak trzęsąca się i pękająca ziemia czy wydobywające się spod powierzchni „piekielne” opary.

Duch przemawia do Hamleta jakby był w transie, w który próbuje też wprowadzić słuchacza. Dla zobrazowania narracji zjawy reżyser przedstawia ją na ekranie, jakby była wyobrażana przez Hamleta. Jak podaje L. Monique Pittman w artykule „A Son Less Than Kind: Iconography, Interpolation, and Masculinity in Branagh's Hamlet", scena spotkania z duchem jest sceną „najbardziej przeładowaną cięciami montażowymi w postaci wstawionego materiału”. Na uwagę zasługuje zwłaszcza ukazanie momentu otrucia króla Hamleta przez Klaudiusza, z powiększonym ujęciem wlewania trucizny do ucha. Żaden inny reżyser nie zastosował w owej scenie tylu zbliżeń detali twarzy postaci. Szczególnie wymowne staje się kilkakrotne „przeskakiwanie” kamery ze zbliżenia demonicznych oczu ducha na przerażone oczy Hamleta. Branagh eksponuje również usta zjawy, tak jakby chciał uchwycić strumień dźwięków jego szokującej opowieści. Lisa S. Starks wspomina o „dziwacznym efekcie wyolbrzymienia jego przemowy, podkreślającym każdą sylabę jego nakazu" (1999: 176).

Na zakończenie spotkania duch próbuje nawiązać bliski kontakt z Hamletem, wyciągając do niego rękę. Hamlet, w odpowiedzi na ten gest, stara się uścisnąć dłoń ojca, lecz praktycznie jednocześnie zjawa znika. W kontrastującym ujęciu widać jej rękę w stalowym uzbrojeniu oraz ludzką rękę Hamleta; ich niemalże nieuchwytne złączenie dłoni to przekroczenie bariery między dwoma światami. Przytłoczony upiornością zjawy, Hamlet upada na ziemię, by za chwilę podnieść się i dojrzeć poszukujących go towarzyszy. Podobnie jak u Zeffirellego, wszyscy przysięgają milczenie, słysząc głos ducha wydobywający się spod ziemi. Natomiast bohater zapowiada swoje pozorowane 
pomieszanie zmysłów jako skutek zmiany percepcji wydarzeń po wizycie zmarłego ojca.

W stechnicyzowanym świecie Almereydy także duch zostaje „pochwycony" przez kamery monitorujące korytarze hotelu Elsynor. 0 zarejestrowaniu owego faktu informuje Hamleta Horacjo i jego dziewczyna Marcella (Almereyda postacią kobiecą zastępuje Szekspirowskiego Marcellusa). Przedstawiają ducha jako zjawisko wizualne, bo nie udaje się nawiązać z nim rozmowy. Almereyda obrazuje na ekranie opowieść Horacja, przy czym jej zakończenie ilustruje poprzez pokazane ducha znikającego w automatycznej maszynie z puszkami Pepsi. Zdaniem Burnetta, nie jest to żart filmowy reżysera, lecz celowy zabieg, mający związek z konsumpcjonistycznymi realiami, w jakich umieszczony jest świat adaptacji (Burnett, 2003: 51). Wyłaniająca się z tej sceny filmowa reprezentacja słuchu Hamleta wskazuje na możliwość wiarygodnego przekazania opowieści jedynie za pomocą słów, ponieważ Hamlet nie otrzymuje żadnego materiału z nagraniem wizyty.

Spotkanie Hamleta ze zmarłym ojcem (w tej roli Sam Shepard) w Hamlecie Almereydy różni od wizji Zeffirellego i Branagha nie tylko całkowite dopasowanie owej sceny do konwencji elektronicznego monitorowania i informowania, ale także zjawienie się ducha w osobistej przestrzeni Hamleta - na balkonie i w jego pokoju. 0 przybyciu zjawy chce go telefonicznie poinformować Horacjo, ponieważ sam zauważa ducha na monitorze. Dzwoni do pokoju hotelowego przyjaciela, lecz Hamlet nie podnosi słuchawki, bo w tej samej chwili dostrzega ducha na swoim balkonie. Postacie oddzielone są szybą, zatem kontakt między nimi nie jest bezpośredni. Almereyda stosuje tutaj trik, polegający na tym, że postaci obserwują się wzajemnie niczym przez ogromny monitor: Hamletowi przygląda się z balkonu postać, z perspektywy której widać, jakby wewnątrz pomieszczenia, w jakim przebywa Hamlet, znajdowały się kraty. Nie są to oczywiście kraty, lecz gra świateł, odbijających się na powierzchni okna i powodujących złudzenie optyczne.

Z kolei z perspektywy Hamleta przybliżanie się zjawy do drzwi balkonowych wygląda niczym wychodzenie ducha z ekranu i wchodzenie do innego świata. Hamlet „zaprasza” ducha do swojego pokoju przez otwarcie przed nim drzwi balkonowych (duch nie przenika przez szyby). W pracy A Companion to Shakespeare's Works: The Tragedies Richard Dutton i Jean Elizabeth Howard podają, że Almereydya „uczłowiecza ducha”, tak iż nie jest on tylko „bytem metafizycznym” (2003: 149), a jego zachowania - w przeciwieństwie do propozycji Zeffirellego i Branagha - są znacznie mniej zdystansowane i pełne ludzkich emocji. Warto zauważyć, że duch Almereydy po prostu „przychodzi" z wizytą; Hamlet nie musi ścigać ani tropić na schodach co chwilę znikającej zjawy.

Zanim zjawa przekroczy próg pokoju syna, prosi, by Hamlet ją wysłuchał. Dopiero po otrzymaniu potwierdzenia słowami: „Będę”, duch wyjawia mu 
przyczynę przybycia i swojego zgonu. Almereyda tak kreuje reprezentację słuchu Hamleta, by podkreślić jego całkowite zaabsorbowanie opowieścią. Zasłuchanie Hamleta jest spotęgowane zachowaniem ojca. Duch wykonuje znamienny gest dotknięcia ucha białą chusteczką, wskazując tym samym „zatrute" przez Klaudiusza ucho. Drugim gestem, i jednocześnie nawiązaniem kontaktu z Hamletem, jest chwycenie go za głowę, a następnie za ramiona, w trakcie odkrywania (tylko dozwolonej) części tajemnic świata pozagrobowego. Almereyda ukazuje ducha, który za pomocą słów i gestów wywołuje „wstrząs percepcyjny" u syna. Hamlet wydaje się przestraszony wizytą przybysza oraz tym, co mu wyjawia, a widok pałającego chęcią zemsty zmarłego ojca wpływa na jego bezpośrednie doświadczenia wizualne i audialne oraz na aktualne postrzeganie wydarzeń. Warto dodać, że scena jest bardzo dynamiczna pod względem interakcji między duchem a Hamletem: postaci przemieszczają się po pokoju, Hamlet zostaje przyparty do ściany, na chwilę nawet przysiada na fotelu. Ostatecznie uściskiem przypieczętowują „pakt”. W trakcie gestu pożegnania ojciec kieruje wprost do ucha Hamleta znamienne słowa, by o nim nie zapominał. Symbolicznie można odczytać to zachowanie jako wyjątkowo sugestywne „wlanie toksycznych słów” do ucha słuchacza. Z takim przesłaniem duch pozostawia Hamleta, odchodząc pośpiesznie i nie odwracając się w jego stronę. Zapewne ma to podkreślić siłę oddziaływania jego ostatnich słów - w formie nakazu, wyszeptanego w bezpośrednim kontakcie z odbiorcą. Być może właśnie ta relacja synowsko-ojcowska okaże się najbardziej „ludzka”, pełna prawdziwych emocji i zaangażowania zmysłów, w porównaniu z ogólną tendencją do ukazania przez Almereydę „pozbawionej uczuć relacji ludzkich w filmie" (Burnett, 2003: 51).

Filmowe reprezentacje zmysłów w każdej ze scen spotkania Hamleta z duchem ojca wskazują na wykorzystanie zmysłów jako narzędzi wpływu w relacji ojciec-syn. Koncentrujacy się na postrzeżeniach wzrokowych i słuchowych bohater, wszelkie swoje dalsze poczynania uzależnia od wiedzy nabytej od ojca. Poddanie pod wątpliwość, czy jest ona prawdziwa, czy fałszywa, rozstrzyga się stopniowo, między innymi dzięki zaangażowaniu zmysłów w aktywne obserwowanie i słuchanie innych bohaterów tragedii.

\section{Widzieć i być widzianym, słyszeć i być słyszanym: relacje wzrokowe i słuchowe między filmowymi postaciami dramatu}

W swojej wersji dramatu Zeffirelli niekiedy porzuca koncepcję publicznego ukazywania bohaterów na rzecz osobistych konfrontacji między nimi, stąd niektóre fragmenty Szekspirowskich scen, zamiast na oczach tłumu, rozgrywają się w prywatnych pokojach zamkowych. Na przykład Hamlet Zeffi- 
rellego nie uczestniczy w uroczystej przemowie Klaudiusza, co skutkuje tym, że fragment, w którym odbywa się rozmowa pomiędzy nim a parą królewską, przeniesiony zostaje przez reżysera do komnaty Hamleta. Zeffirelli podkreśla izolację głównego bohatera, co dobitnie pokazuje fragment sceny, w której samotny Hamlet przesiaduje w zaciemnionym pokoju i dopiero przybycie Gertrudy wraz z Klaudiuszem „budzi” go z letargu. Zanim nowa para królewska wtargnie do komnaty księcia, Gertruda w bardzo czuły sposób, całując i szepcząc „coś” wprost do ucha Klaudiusza, przekona go, by wspólnie poszukali Hamleta. Oba zmysły Klaudiusza - wzrok i słuch - są mocno poruszone. Jego słuch ulega słowom Gertrudy, a wzrokiem zdaje się „pożerać” wdzięki żony (niemalże w każdej scenie). Warto zwrócić uwagę, że mroczny pokój to kolejny element (obok zakapturzonego mnicha, widocznego w scenie pogrzebu) kreowania Hamleta na postać pragnącą pozostać w ukryciu, maskującą ekspresję twarzy, a przez to również własne wnętrze. Początkowe odgradzanie się głównego bohatera od otoczenia można zinterpretować jako chęć wyeliminowania bodźców percepcyjnych wizualnych i audialnych, płynących z zewnątrz; chęć pozostania z samym sobą - z obrazami „oka umysłu” i dźwiękami „dialogu wewnętrznego".

Oddziaływanie percepcyjne między postaciami w tej scenie oparte jest na wymianie spojrzeń i krótkim, lecz zacieśniającym relacje układające się w trójkąt (Hamlet-Gertruda-Klaudiusz) dialogu. Nieudaną próbę rozmowy z Hamletem podejmuje jego stryj. Hamlet ignoruje jego wzrok; stara się również okazać, że bagatelizuje prośbę Klaudiusza, by pozostał na dworze. Ostatecznie, po porozumiewawczym spojrzeniu Gertrudy, nowo koronowany król pozostawia w komnacie Hamleta z matką. Królowa stara się namówić syna do zmiany nastawienia wobec nowej sytuacji po stracie ojca. Prosi Hamleta, by „patrzył na króla przyjaźniejszym okiem”. Odwołanie do percepcji wzrokowej nabiera tutaj szczególnego znaczenia, jeśli wziąć pod uwagę sposób, w jaki Hamlet wyraża swój stosunek do nowego męża Gertrudy, a mianowicie wysyłanie podejrzliwych i wrogich spojrzeń w kierunku Klaudiusza.

Można powiedzieć, że Gertruda stosuje „miękkie narzędzia” percepcyjnego oddziaływania. Należą do nich przede wszystkim delikatne użycie głosu oraz łagodne spojrzenia, w połączeniu z wykorzystaniem zmysłu dotyku. Początkowo nieśmiało patrzy na Hamleta, lecz ten nie odwzajemnia spojrzenia. Matka podchodzi do niego z boku i obejmuje go za ramię, niemalże szepcząc mu do ucha i namawiając, by porzucił swój pesymistyczny punkt widzenia. Syn jednak na chwilę „odtrąca” matkę, odchodząc w inną część komnaty. Taki unik prawdopodobnie świadczy o możliwościach wpływu Gertrudy na syna, ale równocześnie o jego niechęci do zaakceptowania punktu widzenia matki. Zeffirelli ukazuje bardzo bliską relację wizualno-audialną między nimi. Hamlet, podobnie jak inni męscy bohaterowie dramatu, wydaje się znajdować głównie pod wpływem bodźców wzrokowych, jakie - nierzadko w sposób 
manipulatorski - wysyła Gertruda. O nakierowaniu centrum męskiej uwagi na postać Gertrudy pisze Crowl: „Gertruda jest pomyślana jako filmowa diva, będąca złocistą dziewczyną w centrum ponurego męskiego świata” (2003: 51). Uwodzicielski głos królowej ma dużą zdolność oddziaływania na męską percepcję słuchową. Crowl twierdzi, że „[f]ilm Zeffirrellego stale uwodzi wyobrażeniami Gertrudy jako divy, która w świecie opery wyzwala swój blask, ale także utrzymuje dystans poprzez swój głos" (51).

W rezultacie organy słuchu i wzroku Hamleta poddają się manipulacji Gertrudy. Potwierdzeniem tego jest gest przylgnięcia do łona matki, co wywołuje jej czułe pocałunki, składane na twarzy syna. W obecności matki Hamlet wydaje się być pod czarem jej zmysłów. Tuż po jej wyjściu zaczyna wygłaszać monolog zaczynający się od słów „0, gdybyż to nadmiernie trwałe ciało / Zmiękło" (1.2.366-367) i obserwuje z okna swej komnaty scenę pełnego namiętności powitania między Klaudiuszem i Gertrudą. Niejako komentując ten widok, książę z rozczarowaniem wykrzykuje do siebie: „Słabości, imię twe niewiasta" (1.2.387), po czym zatrzaskuje oba skrzydła okna. W ocenie Lawsona jest to wyznaczenie "transparentnej bariery pomiędzy nim a innymi postaciami, zwłaszcza Gertrudą”; ustanowienie „emocjonalnego dystansu" (1997: 235). Zapewne jest to również przejaw nieufności w stosunku do percepcyjnych zachowań Gertrudy, które według Hamleta balansują na granicy manipulatorskiej teatralności i nieudawanych uczuć. Dodatkowo warto wspomnieć, że w tej scenie ciekawym zabiegiem wizualnym jest zestawienie przez reżysera jasnej sukni Gertrudy z czarnym strojem Hamleta, a także symboliczna gra światłem: z początkowo zaciemnionego i mrocznego pokoju, po odsłonięciu przez Gertrudę potężnej kotary, w pomieszczeniu robi się słonecznie i jasno.

Inną istotną relacją, która obrazuje filmowe reprezentacje wzroku i słuchu w adaptacji Zeffirellego, jest układ, jaki tworzy się pomiędzy Ofelią (Helena Bonham-Carter) a trzema męskimi postaciami: ojcem, bratem i Hamletem. Scena pouczania Laertesa przed jego wyjazdem oraz instruowania Ofelii w zakresie jej zachowań w stosunku do Hamleta ulokowana jest przez reżysera na dziedzińcu zamkowym. Bohaterka ma okazję przysłuchiwać się naukom kierowanym przez Poloniusza do syna, a po chwili sama wysłuchuje ojcowskich zaleceń. Dialog między postaciami staje się dynamiczny, dzięki postawie Ofelii. Choć Poloniusz stara się całkowicie zawładnąć jej percepcją słuchową, między innymi poprzez podniesiony głos, dziewczyna wydaje się tonem głosu wyrażać nieposłuszeństwo. Co więcej, w nieco buntowniczy sposób (zachodząc ojcu drogę i chwytając go za ramię) stara się przekonać ojca, że wyznania miłosne Hamleta są autentyczne. Ofelia powołuje się na jego święte przyrzeczenia, których wiarygodność podważa Poloniusz. Uprzednio w komnacie, w której bohaterka spędza czas na wyszywaniu, nachodzi ją brat. Laertes używa ostrzegawczego języka i wysyła w jej stronę przejmujące 
spojrzenia, po to, by przestrzec siostrę przed nietrwałymi zamiarami Hamleta. Ofelia nie spogląda bratu w oczy, a jej wymijająca odpowiedź może wskazywać na chęć zbagatelizowania braterskiej porady.

Z kolei na ojcowski zakaz, dotyczący dalszych prywatnych rozmów z Hamletem, Ofelia reaguje posłuszeństwem, lecz ton jej głosu sugeruje brak pokory. Zdaniem Sylwii Kołos, Ofelia Zeffirellego w swej wypowiedzi:

Będę posłuszna, zawarła z jednej strony gorycz i smutek dojrzałej kobiety, z drugiej stanowczy i bardzo młodzieńczy, choć tylko wewnętrzny, sprzeciw wobec elsynorskiej rzeczywistości. Ofelia jest tylko córką Poloniusza, tylko kobietą na królewskim dworze, dlatego jedyny luksus, na jaki może sobie pozwolić, to wewnętrzna niezgoda ukryta pod maską posłuszeństwa (2007: 141).

Ostatnie spojrzenie, które posyła ojcu, najpełniej wyraża wewnętrzny sprzeciw, a nawet krnąbrność bohaterki. W wersji Zeffirellego spotkanie to obserwuje z dystansu Hamlet, bo w tym samym czasie przechadza się po zewnętrznych, odsłoniętych kondygnacjach zamku. Jego szpiegowska postawa pozwala mu zarówno obejrzeć, jak i usłyszeć całe zajście. Reżyser pozwala zatem, by główny bohater posiadł wiedzę, jakiej nie posiada „nieświadomy” owych instruktarzy Hamlet Branagha i Almereydy.

Zeffirelli ukazuje też odwrotną sytuację, czyli taką, w której Poloniusz staje się obserwatorem „nawiedzenia” Ofelii przez Hamleta w jej komnacie. Zmiana w stosunku do przedstawienia tej sceny w Hamlecie Szekspira polega na tym, że w dramacie to Ofelia relacjonuje ojcu owo spotkanie w formie narracji „sceny poza sceną”. W filmowym Hamlecie z 1990 roku reżyser rezygnuje z tej konwencji (nie stosuje też retrospekcji) na rzecz sfilmowania spotkania bohaterów, którym towarzyszy niemy i niewidoczny świadek w postaci Poloniusza. Szpieg ukrywa się na wysokości jednego z zamkowych przejść.

Zeffirelli oddaje pełne zaskoczenie Ofelii wywołane wizytą Hamleta. Dziewczyna, która półgłosem podśpiewuję balladę o Świętym Walentym, odkrywa obecność Hamleta w komnacie, słysząc dźwięk dobiegający z innej części pomieszczenia. Przerywa wówczas haftowanie oraz nucenie piosenki i zwraca oczy w stronę siedzącej przy oknie „zjawy” - Hamleta. Dzieli ich odległość stołu, który Hamlet obchodzi, by stanąć twarzą w twarz z nieco spłoszoną i oczekującą wyjaśnień Ofelią. Bohaterowie nawiązują kontakt poprzez spojrzenia i bezdźwięczne ruchy warg. W pewnym momencie Hamlet decyduje się na krótkie i gwałtowne pochwycenie Ofelii, po czym prowadzi ją za rękę w kierunku okna. Jednak po chwili odchodzi od dziewczyny i z ciężkim westchnieniem opuszcza pokój, nieustannie się w nią wpatrując. Ofelia także pozostaje niema, a jedyny gest, jaki wykonuje, stanowi zakrycie dłonią ust (z przejęcia). Wydaje się, że w tej scenie Ofelia dostosowuje się do dwuznacznego kontaktu wzrokowego i ambiwalentnego milczenia, narzuconego przez Hamleta. Jest to kolejna scena (obok początkowej sceny pogrzebu) dobitnie 
pokazująca pantomimiczne zachowania postaci. W dodatku powyższe rozwiązanie filmowe jest o tyle istotne dla dalszego rozwoju akcji, że Poloniusz staje się bezpośrednim uczestnikiem spotkania. Donosząc parze królewskiej o wizycie Hamleta, nie relacjonuje narracji córki, lecz tworzy własną na podstawie obserwacji i podsłuchiwania.

W adaptacji Branagha główną wytyczną stanowi fabuła Szekspirowskiego Hamleta. Reżyser przedstawia zatem scenę oficjalnego przemówienia Klaudiusza (Derek Jacobi) zgodnie z didaskaliami „oryginalnego scenariusza". W weselnej oprawie nowy władca wygłasza mowę, adresowaną do dużego grona zebranych dworzan, w ogromnej, jasnej, pełnej luster, głównej sali pałacowej. Można pokusić się o stwierdzenie, że wizualnym i symbolicznym potwierdzeniem zmian w państwie duńskim jest Gertruda (Julie Christie) ubrana w suknię ślubną. Jej wzrok, co chwilę kierowany na męża, oraz atencja, z jaką wsłuchuje się w jego słowa, stanowią kolejne sygnały aprobujące przemiany na dworze. Klaudiusz sprawnie włada słowem, wywołując brawa słuchaczy. Jedyną postacią „głuchą" na jego słowa i nieco oddaloną (zwróconą bowiem bokiem do umieszczonej w centrum uwagi królewskiej pary) pozostaje Hamlet. Klaudiusz publicznie podejmuje próbę uzyskania przychylności bratanka. Hamlet reaguje na pytanie odnoszące się do jego posępnej postawy wyjściem z ukrycia i zajęciem jednego z krzeseł, niczym tronu, którego został pozbawiony. Dopiero w tym miejscu rozmowę z synem nawiązuje Gertruda; królowa prawie przyklęka przed Hamletem. Dołącza do niej Klaudiusz, co powoduje, że obydwoje starają się namówić go do zaakceptowania nowej sytuacji. Klaudiusz stara się wpłynąć na percepcję słuchową Hamleta. Pozoruje swój wywód na autentycznie szczery w stosunku do bratanka, mówiąc do niego niczym ojciec do syna.

Ostatecznie Gertruda i Klaudiusz teatralnie „przeciągają” Hamleta na swoją stronę, umieszczając go między sobą i ogłaszając pierwszym w kolejności pretendentem do tronu. Osaczony z jednej strony przez Klaudiusza, a z drugiej przez matkę, Hamlet potwierdza rezygnację z wyjazdu do Wittenbergii. Interesującym rozwiązaniem filmowym jest ustawienie Hamleta w stroju w kolorze mrocznej czerni pomiędzy dwiema postaciami, z których jedna ubrana jest w śnieżnobiałą suknię (Gertruda), a druga w ognistoczerwony mundur (Klaudiusz). Zwieńczeniem tej sceny jest spadające białe konfetti, które sygnalizuje zbliżającą się ucztę pełną radości. W tym samym czasie para królewska wraz z całym dworem opuszcza salę tronową. Branagh pokazuje, jak zaraz po ceremonii do samotnie stojącego Hamleta podchodzi Ofelia (Kate Winslet) i chwyta go za dłoń. Jednak tuż za nią podąża Laertes, który skutecznie odsuwa ją od księcia. Jest to dopiero pierwszy z wielu sygnałów oznaczających, że mężczyźni na każdym kroku roztaczają opiekę nad Ofelią; opiekę przybierającą formę patriarchalnych ograniczeń stawianych jej niemalże na każdym kroku. 
W końcu Hamlet zostaje w pustej sali, decydując się na uzewnętrznienie monologu i kontemplację własnych odbić w lustrach. Pierwszy monolog bohatera stanowi formę obnażenia wewnętrznych obserwacji na temat rychłego zamążpójścia matki i własnej wobec tego bezsilności. Zdaniem Laniera, autora artykułu „»Art Thou Base, Common and Popular?«: The Cultural Politics of Kenneth Branagh's Hamlet”, monolog Hamleta „O gdybyż to nadmiernie trwałe ciało / Zmiękło” (1.2.376-377) kładzie akcent na to, jak „dworskie poprawne zachowanie powstrzymuje go [Hamleta] od wyrażenia osobistego żalu po śmierci ojca oraz z powodu znieważenia jego pamięci przez matkę" (2002: 159). Innymi słowy, możliwości ekspresyjne bohatera zostają ograniczone przez „rozgrywki percepcyjne” obowiązujące na dworze elsynorskim.

Branagh rozbudowuje owe „rozgrywki percepcyjne” w adaptacji sztuki przez wbudowanie w nie relacji pomiędzy Ofelią i mężczyznami. Tutaj istotna z punktu widzenia filmowych reprezentacji wzroku i słuchu okazuje się scena, w której Poloniusz instruuje swoje dzieci. Reżyser umieszcza ten fragment dramatu w pałacowej kaplicy, dzięki czemu przyjmuje on formę moralizatorsko-konfesyjną: udzielenia kazania Laertesowi oraz wymuszenia spowiedzi Ofelii. Poloniusz oddziałuje przede wszystkim na percepcję słuchową syna, choć także Ofelia przysłuchuje się prawieniu morałów przez ojca. Gdy Laertes opuszcza kaplicę, Poloniusz zamyka kraty tego pomieszczenia i prowadzi córkę w stronę konfesjonału, a następnie gwałtownym ruchem wpycha ją do wnętrza i sadza na spowiedniczej ławce. Wbijając w nią inwigilacyjny wzrok i zadając krępujące pytania, wymusza na Ofelii wyznanie prawdy na temat jej związku z Hamletem. Branagh kontrastuje oświetloną twarz Poloniusza, jego pewne spojrzenie i autorytarny głos z pozostającą w słabszym świetle Ofelią, jej spuszczanymi co chwilę powiekami, drżącym głosem i niepewnością charakteryzującą wypowiedzi dziewczyny.

Niespotykaną w innych adaptacjach strategią jest zastosowanie przez Branagha retrospekcji przedstawiającej namiętną, seksualną relację między Ofelią i Hamletem. W trakcie spowiedzi Ofelia przypomina sobie sceny z intymnych spotkań z kochankiem. Nabierają one grzesznego charakteru, ponieważ ostatecznie bohaterka zostaje zmuszona przez Poloniusza do zaprzestania kontaktów z Hamletem. Tylko „oko umysłu” dziewczyny może zachować obrazy, których powinno wystrzegać się jej „oko ciała”. Ostatnia wypowiedź Ofelii, już po odejściu ojca, stanowi wymuszoną akceptację nakazu Poloniusza. Dziewczyna w myślach wypowiada słowa: „Posłuszeństwa / Dochowam, panie" (1.4.680-681), czemu towarzyszy wizualizacja wspomnienia wspólnie spędzonej nocy z Hamletem.

Z kolei wynikające ze struktury dramatu „nawiedzenie” Ofelii przez Hamleta Branagh prezentuje w postaci opowieści, którą córka kieruje do Poloniusza. 0 ile Zeffirelli bezpośrednio ukazuje na ekranie przebieg wizyty księcia w komnacie Ofelii, o tyle Branagh stosuje ten sam zabieg co Szekspir 
- ekfrastycznie zwerbalizowany obraz w formie narracji. Ofelia Branagha w popłochu wpada do pokoju ojca, by zrelacjonować mu szczegółowo niespodziewane odwiedziny Hamleta. Nieco „histerycznie” odgrywa spotkanie z księciem, jednocześnie opowiadając i ilustrując gestami jego niecodzienne zachowanie. Połączenie elementów wizualnych i audialnych powoduje, że Poloniusz nie ma wątpliwości co do pobudek postępowania Hamleta - przyczynę upatruje w odrzuceniu jego zalotów przez córkę. Poloniusz wykorzystuje opowieść Ofelii do prowadzenia dalszych "gier percepcyjnych" na dworze, stając się inspiratorem zasadzki na Hamleta, w której bohaterka odegra kluczową rolę wabika.

Almereyda natomiast decyduje się na skonfrontowanie bohaterów w trakcie konferencji prasowej, zorganizowanej z okazji przejęcia władzy przez Klaudiusza. Pierwszą zauważalną postacią jest Hamlet, trzymający w ręku kamerę i nagrywający przemowę stryja. W artykule, który omawia adaptację tego reżysera, Melissa Croteau podaje, że „Almereyda decyduje się dać Hamletowi zabawkę, przestarzałą kamerę Fischer-Price PXL-2000 Pixelvision" ([podkreślenie autorki] 2009: 111). Z kolei, zdaniem Rasmus, przez swoją wszechobecność kamera staje się „,jednym z ważniejszych bohaterów w filmie” (2001: 157).

Nowy szef firmy „Dania” wygłasza uroczystą mowę, w której informuje zebranych o śmierci brata oraz poślubieniu jego żony. Almereyda daje tym samym do zrozumienia, że to głos Klaudiusza (Kyle MacLachlan), wsparty odpowiednią gestykulacją, ma decydujący wpływ na zmysły odbiorców, ponieważ swoją przemową ustanawia on nowe relacje i nowy porządek w państwie. Gertuda (Diane Venora) towarzyszy Klaudiuszowi, siedząc obok niego, z uwielbieniem przyglądając się mężowi i wsłuchując się w jego słowa. Jedyną jej wypowiedzią jest podziękowanie wszystkim za społeczne przyzwolenie na owe zmiany. Publiczne wyrażenie wdzięczności nosi znamiona zabiegu komercyjnego - całe wystąpienie wydaje się dopracowane ze szczegółami, wyreżyserowane przez dobrze znającego wymogi świata biznesu Klaudiusza. Wystąpienia publiczne są zapewne dla niego przyjemnością, a wystudiowane ruchy i odpowiednia artykulacja potwierdzają jego swobodę w tworzeniu przekazów wizualnych i werbalnych.

W trakcie przemówienia Klaudiusza rozgrywa się też „wyścig spojrzeń”. Ofelia (Julie Stiles) próbuje przyciągnąć wzrok Hamleta, by zaproponować mu miejsce i godzinę spotkania. W tym celu rysuje na kartce obrazek przypominający fontannę wraz z sugerowaną godziną schadzki. To bardzo prosta i tradycyjna forma komunikacji, która kontrastuje z nagminnie stosowanymi w filmie technologicznymi rozwiązaniami, i może wyrażać „nostalgiczną tęsknotę za przedkapitalistycznym porządkiem doświadczenia" (Burnett, 2003: 57). Almereyda chwilowo skupia się na Ofelii, która siedzi pomiędzy ojcem a bratem i wymownym spojrzeniem prosi o przekazanie kartki Hamletowi. Jest to symboliczne "trzymanie bohaterki w ojcowsko-braterskim uścisku”. 
Odmowie brata towarzyszy niezadowolone spojrzenie Poloniusza rzucone w stronę córki, bo siedząc tak blisko niej, bez trudu odczytuje „zaszyfrowaną” wiadomość. Dopiero po zakończonym wystąpieniu i opuszczeniu sali z trudem udaje się Ofelii podać kartkę Hamletowi. Nie słychać rozmowy między nimi i trudno stwierdzić, jakie informacje sobie przekazują. Almereyda na planie głównym umieszcza bowiem Klaudiusza i Gertrudę u jego boku oraz Poloniusza wraz z Laertesem. „Niesłyszalna” rozmowa Hamleta i Ofelii jest ciągle przerywana przez ojca i brata, odciągających ją od księcia.

W interpretacji Almereydy Ofelia jest postacią, która z trudem walczy o własne, niezależne od męskich wpływów możliwości postrzegania świata wokół niej. Reżyser nie rezygnuje ze sceny, w której Poloniusz daje rady swoim dzieciom i poucza je - scenę tę umieszcza w mieszkaniu Poloniusza. Początkowo Laertes i Ofelia przebywają tam sami, dzięki czemu brat ma szansę przestrzec siostrę przed ulotnym uczuciem Hamleta. Ofelia siedzi obok brata, zwrócona bokiem, co powoduje, że Laertes ma bezpośredni dostęp do wrażliwego ucha siostry. Dziewczyna milcząco okazuje niezadowolenie, w tym czasie oglądając zdjęcie, które przedstawia Hamleta. Kolejnymi widocznymi oznakami dezaprobaty dla pouczeń brata są: unikanie kontaktu wzrokowego, chodzenie po pokoju i grymasy na twarzy.

Także ojciec stara się w znaczący sposób wpłynąć na punkt widzenia Ofelii. Wypytuje o charakter jej znajomości z księciem, po czym podważa wiarygodność słów Hamleta, a ostatecznie zakazuje dalszych swobodnych rozmów, zacieśniających ich relację. Almereyda portretuje bohaterkę w tej scenie odmiennie niż Zeffirelli czy Branagh. Ofelia Almereydy nie wypowiada słów potwierdzających posłuszeństwo. Jej postawa odznacza się powątpiewaniem w to, co słyszy od ojca, w połączeniu z niemożnością wyrażenia buntu. Ofelia lekko otwiera usta $w$ geście zaniemówienia, a jej wzrok oddaje zdumienie, w jakie wprawiają ją słowa ojca. Wydaje się, że bohaterka, mimo iż dysponuje językowymi środkami wyrażającymi sprzeciw, wybiera chwilowe milczenie i pogrążenie $w$ wewnętrznych, niezwerbalizowanych przemyśleniach. Ofelia Almereydy ma wynikające ze scenariusza (ograniczenie jej wypowiedzi do minimum) niewielkie możliwości wpływania na zmysł słuchu innych postaci.

Na uwagę zasługuje fakt, że na różnych etapach rozwoju akcji filmowej reżyser poświęca krótkie pantomimiczne sceny tylko Ofelii. Jedna z nich pokazuje, jak dziewczyna czeka na Hamleta w umówionym miejscu przy fontannie (przypomina ona miniwodospad i jest wbudowana w strukturę muzeum Guggenheima w Nowym Jorku). By zaznaczyć wizualną obecność Ofelii w adaptacji, Almereyda ukazuje ją zarówno w powiększeniu, jak i z oddali, w trakcie oczekiwania. Szum fontanny prawdopodobnie odpowiada wewnętrznemu stanowi umysłu bohaterki, niemogącej pozbyć się myśli o niestawieniu się Hamleta na umówioną „randkę”. Ofelia początkowo siedzi na brzegu fontanny, by wkrótce, w zniecierpliwieniu, przechadzać się po jej kra- 
wędziach. Miejsce to nabierze szczególnego znaczenia, bo w tej samej fontannie zostanie odnalezione jej martwe ciało.

Almereyda przenosi kolejną scenę na ulice miasta. Croteau podkreśla znaczenie scenerii w tej scenie filmowej. Podaje, że „ironię ludzkiej znikomości w »jaskini« drapaczy chmur zbudowanych przez człowieka", oddają ujęcia od dołu - wydłużające wysokie budowle tak, że przy nich ludzkie postacie wyglądaja karłowato" (2009: 113). Na początku omawianej sceny widać Hamleta idącego wzdłuż ulicy, w stylizowanej na indiańską czapce „z uszami” i żółtych okularach. Zewsząd otaczają go olbrzymie budowle, zaś tuż za nim podążają: Gertruda (w ciemnych okularach), Klaudiusz (bez okularów), jego ochroniarz (w okularach). W tle słychać odgłosy miasta - samochody i szum uliczny. Najpierw zaczyna przemawiać Klaudiusz, pytając: „I czemuż wciąż nad wami wiszą chmury?". Brak reakcji Hamleta powoduje, że matka podchodzi do niego, usiłując przekonać syna, aby zmienił nastawienie do stryja. Sugeruje, by przyjaźniejszym okiem spojrzał na „Danię” i zaakceptował zmiany. Hamlet tłumaczy swoje podejście autentycznością przeżyć wewnętrznych, jednocześnie zdejmując okulary i odsłaniając oczy. Te same okulary towarzyszą mu w prologu do filmu, kiedy ogląda czarno-białego samego siebie na ekranie monitora przez żółte szkła okularów, „zabarwiając” tym samym obraz na jeden kolor.

Próba wpłynięcia na syna przechodzi w pozbawioną sentymentów i tylko pozornie uprzejmą rozmowę z Klaudiuszem. Wraz z Gertrudą, która wsiada do limuzyny, przekonują go do pozostania w mieście. Matka argumentuje prośbę tym, by Hamlet przebywał pod ich czujnym okiem. Znamienne jest to, że Gertruda wypowiada te słowa zaraz po uchyleniu czarnego okna limuzyny i zsunięciu swoich ciemnych okularów. Obraz uchylonego okna i częściowo ściągniętych okularów sugeruje, że oczy matki w sensie metaforycznym zwykle pozostają przesłonięte przez zaciemniające widoki, dodatkowe „szyby”. Natomiast Almereyda kreuje Klaudiusza na otwartego i niemającego niczego do ukrycia władcę, biznesmena oraz męża. Przejmując władzę nad korporacją „Dania”, wydaje się on mieć „jasną wizję", a ukrywanie się za okularami mogłoby sugerować albo jego nieszczerość, albo zakładanie osłony na oczy w celu maskowania się. W mieście, w którym wszystko jest przesłonięte przez jakiś rodzaj szklanej, transparentnej bariery lub odbijającej powierzchni, Klaudiusz wyróżnia się przejrzystością spojrzenia i wizualną dostępnością swoich oczu.

\section{Matnia intryg szpiegowskich w Elsynorze Zeffirellego, Branagha i Almereydy}

Intrygi $\mathrm{w}$ adaptacji Zeffirellego $\mathrm{w}$ dużej mierze kształtowane są przez postrzeganie (przez filmowych bohaterów) przestrzeni, w jakiej rozgrywa się akcja dramatu. Zamek elsynorski, częściowo odcięty od świata przez mo- 
rze, okazuje się idealnym miejscem zastawiania pułapek. Ich realizacji służy głównie zmysł wzroku, ponieważ średniowieczny zamek oferuje niemalże nieograniczone możliwości podglądania jednych bohaterów przez drugich: z murów zamku, z krużganków, z przejść między kondygnacjami, zza filarów i zza drzwi. Natomiast zmysł słuchu pozwala na uzupełnienie wiedzy, której dostarcza postrzeganie wzrokowe. Postrzeganie słuchowe wielokrotnie też modyfikuje perspektywę bohaterów i wyznacza ich wewnętrzne przemiany, jak na przykład w przypadku udawanego szaleństwa Hamleta po usłyszeniu opowieści ducha.

U Zeffirellego Hamlet początkowo obserwuje wydarzenia z pozycji wertykalnej. Jak podaje Kołos, w tej adaptacji dramatu pojawia się

wyznaczany przez architekturę zamku i akcentowany w filmowej inscenizacji kierunek wertykalny, który funkcjonuje w filmowym obrazie jak metaforyczny opis moralnego upadku człowieka, „boskiego arcydzieła”, istoty najbardziej podatnej na działanie zła w każdej postaci. Ten symboliczno-przestrzenny układ dotyczy głównie samego Hamleta (2007: 194).

Reżyser utwierdza widza w przekonaniu, że w jego adaptacji najistotniejsze stają się rozterki i poczynania Hamleta. Zeffirelli odnotowuje zmianę sposobu widzenia bohatera:

\footnotetext{
W trakcie rozwoju akcji zmienia się bowiem wyraźnie perspektywa, z jakiej książę obserwuje życie dworu po śmierci ojca. Początkowo ogląda Elsynor i jego mieszkańców z góry, z okien, balkonów, wysokich krużganków; nieco później jego obserwacje określa perspektywa antynomiczna. Hamlet zaczyna schodzić coraz niżej, gdyż nie może pozostawać już tylko obserwatorem. Musi zacząć działać, a konieczność działania to także konieczność zmiany perspektywy (194).
}

Dla zmiany perspektywy postrzegania istotna jest też scena odtrącenia Ofelii przez Hamleta, w której bohater działa jeszcze na kilku poziomach. Najpierw książę dostrzega z krużganku zamkowego spiskujących poniżej Klaudiusza z Poloniuszem. Następnie widzi pośpiesznie oddalających się konspiratorów oraz Ofelię, pozostawioną przez nich w jednym z zamkowych holi. U Zeffirellego Szekspirowska scena zostaje w dużej mierze przeorganizowana pod względem tekstualnym, jednak jej wydźwięk pozostaje ten sam - skonfrontowanie zmanipulowanej przez Poloniusza Ofelii z „oświeconym” przez opowieść ojca Hamletem. Odpowiedni montaż filmowy omawianego fragmentu uwypukla genderową relację werbalno-wizualną bohaterów.

„Przypadkowe” spotkanie tych dwojga wydaje się rozwijać w sposób korzystny dla Ofelii. Dziewczyna z lekką nieśmiałością i spuszczonym wzrokiem oddaje Hamletowi pamiątkę, którą jej ofiarował (złota obręcz na łańcuchu). W tym miejscu bohaterka odgrywa swą rolę zgodnie z nakazem ojca, by jednak po chwili wyzwolić tłumioną buntowniczość. Gdy książę zaprzecza, by 
kiedyś ją czymś obdarował, Ofelia reaguje zaskakująco gwałtownie, chcąc obnażyć kłamliwe stwierdzenie Hamleta. Przewaga Ofelii - jej pewny ton głosu, działający drażniąco na uszy Hamleta, jej śmiałe spojrzenie, irytujące księcia - jest ulotna. Po chwili bowiem mężczyzna przypuszcza na nią atak, zwłaszcza po świadomym kłamstwie (po którym dziewczyna zasłania usta książką do nabożeństwa) na temat miejsca przebywania jej ojca. Ofelia utrzymuje, że Poloniusz, którego Hamlet nakrył na chowaniu się wraz z Klaudiuszem za filarem, jest w domu.

Przez zastosowanie zabiegu operatorskiego - ruchu kamery wokół Ofelii - Zeffirelli pokazuje wzbierającą w bohaterze złość. Jak twierdzi Lawson:

\footnotetext{
Zpunktu widzenia Ofelii, poprzez tę technikę, pogłębione zostaje odczucie pochwycenia jej w pułapkę oraz zastraszenie. Strzelista, wertykalna przestrzeń pomieszczenia jedynie intensyfikuje poczucie usidlenia i oszałamiający zawrót głowy, wraz z tym, jak scena zmierza w stronę kulminacji dramatycznego napięcia (1997: 237).
}

Filmowe doświadczenia wizualne i audialne Ofelii są nie tylko intensywne, bolesne i upokarzające, lecz zapisując się zarówno na ciele, jak i w umyśle, mają skutki dla przyszłej kondycji psychosomatycznej bohaterki. Ofelia, nie mogąc znieść wykrzykiwanych na jej temat oszczerstw, odwraca się do Hamleta plecami. On jednak nie rezygnuje z agresywnych zachowań i fizycznie znieważa dziewczynę. Między innymi, kiedy wypowiada kwestię o kobiecych praktykach malowania/maskowania twarzy, chwyta ją mocno dłonią za twarz, wbijając palce w policzki i zniekształcając rysy przerażonego oblicza Ofelii.

Zdaniem Xiafenga Mou, autora artykułu „Cultural Anxiety and the Female Body in the Zeffirelli's Hamlet", reżyser znacząco skraca tekst Ofelii w porównaniu z kwestiami Hamleta (2009: 57). Ponadto przeorganizowanie tego fragmentu i umieszczenie wersu, w którym Hamlet wysyła Ofelię do klasztoru w scenie wystawienia „Pułapki na myszy”, jest przeniesieniem części werbalnej agresji do kolejnej sceny (56). Furia Hamleta objawia się również fizycznie, kiedy popycha Ofelię w kierunku ściany - w miejsce, gdzie wcześniej upadł zwrócony mu podarunek. Odrzucona przez Hamleta, zraniona słowami i gestami Ofelia nie znajduje żadnego oparcia w ojcu. Bezwzględny i nieczuły Poloniusz w wersji Zeffirellego zajmuje się tylko dalszym spiskowaniem, nie zwracając uwagi na córkę.

W adaptacji Hamleta z 1990 roku próba uniknięcia przez Ofelię uczestnictwa w zaaranżowanej przez Poloniusza scenie spotkania z Hamletem przybiera formę próby jej zmysłów. Sensorycznie częściowo zniewolona przez ojca, tzn. „zainfekowana” jego słowami i obrazami, dotyczącymi jej miejsca w hierarchii społecznej, Ofelia ostatecznie powstrzymuje te oznaki postrzegania wizualnego i słuchowego, które przeciwstawiłyby się męskiej domi- 
nacji w zakresie kontroli kobiecych zachowań. Jej chwilowa odwaga, przejawiająca się w spojrzeniach i wypowiedziach, skierowanych na/do Hamleta, w rzeczywistości obraca się przeciwko niej, a w konsekwencji prowadzi do transgresyjngo i oswobadzającego z wszelkich szablonowych zachowań pomieszania zmysłów.

W omawianej scenie Hamlet po raz ostatni powraca na pozycję obserwatora z poziomu wertykalnego. Schodzi na "niższy poziom” na spotkanie Ofelii, a po jego zakończeniu wraca do jednego ze swych punktów obserwacyjnych. Zza uchylonych drzwi na balkonie zamkowym podgląda i podsłuchuje komentujących zajście konspiratorów. Dzięki temu dowiaduje się o planie wysłania go do Anglii. Od tej pory Hamlet będzie działał nieco inaczej niż z ukrycia - wertykalne położenie zamieni na bezpośrednią konfrontację, czyli twarzą w twarz, z innymi bohaterami dramatu.

Przykładem eksperymentu pozwalającego Hamletowi (w tej adaptacji) na wyjście z ukrycia i śledzenie oddziaływań percepcyjnych między pozostałymi bohaterami jest wystawienie „Pułapki na myszy”. Zeffirelli gromadzi bohaterów dramatu w komnacie zamkowej, z rozstawionymi w różnych miejscach ławami dla dworzan oraz jednym, ustawionym nieco bardziej z tyłu, rzędem ogromnych siedzeń dla pary królewskiej, Hamleta, Poloniusza i Ofelii. Takie rozlokowanie postaci sprawia, że właściwie bez trudu mogą obserwować się wzajemnie i podsłuchiwać rozmowy sąsiadów. Rozpoczęciu przedstawienia towarzyszy rozluźniona atmosfera, a komnatę wypełniają odgłosy rozmów z sali, dźwięki grajków i popisy błaznów zabawiających zebranych widzów i słuchaczy, zaś oczy poszczególnych postaci zdradzają zaciekawienie przed mającą rozegrać się na scenie sztuką teatralną.

Kamera bardzo dynamicznie pracuje, zmieniając obiekty zainteresowania - począwszy od donośnie i komicznie zapowiadającego występy Poloniusza, przez ujęcia wymiany spojrzeń między Gertrudą a Hamletem, kiedy wspomina on o zaniedbaniu pamięci o zmarłym ojcu, aż po zarejestrowanie seksualnych gestów i pełnej swawoli rozmowy Hamleta z Ofelią. Ta ostatnia, w przeciwieństwie do zlekceważonej Gertrudy, wydaje się, przynajmniej na początku, zadowolona z zainteresowania, jakim obdarza ją Hamlet. Do omawianej sceny Zeffirelli przenosi kilka wersów z wcześniejszej sceny odrzucenia Ofelii, co sprawia, że kontakt wizualny i werbalny staje się bardziej intensywny. Co więcej, kilkakrotnie wypowiedziana przez Hamleta kwestia „Idź do klasztoru” zmienia autopercepcję Ofelii. Początek rozmowy z Hamletem rozbudza w niej nadzieję na jego miłość. Szybko jednak dziewczyna przekonuje się, że książę znów ją odtrąca, nakazując wstąpienie do klasztoru. Łzy i zagubienie, które można dostrzec w oczach Ofelii, świadczą o kolejnym znieważeniu wrażliwej bohaterki.

W trakcie wystawienia „Pułapki na myszy”, która w adaptacji Zeffirellego pomija wstępny element pantomimiczny, obecny w dramacie Szekspira, zachodzą także inne interesujące oddziaływania między postaciami. Niejed- 
noznaczny kontakt wzrokowy oraz uwagi Hamleta adresowane do Gertrudy świadczą o narastającym napięciu między matką i synem. Jego koncepcja sztuki-w-sztuce wymierzona jest nie tylko w sumienie Klaudiusza. To również zestaw norm kulturowych, których celem jest dotarcie do - jego zdaniem - grzesznej duszy matki. Gra aktora przedstawiającego królową powoduje, że Gertruda niespokojnie, ale dyskretnie rozgląda się na boki, potwierdzając, że wewnętrznie utożsamia się z postacią na scenie. Zewnętrznie zaś ma okazję temu zaprzeczyć, bo zapytana przez Hamleta, jak podoba się jej sztuka, odpowiada, iż sceniczna królowa zbyt wiele obiecuje. Zdaniem Mou, akcent, który Gertruda wręcz nienaturalnie kładzie na ostatnie słowo, dowodzi jej niechęci do zbyt pochopnego składania podobnych obietnic, ponieważ zamykają one drogę do jej dalszego szczęścia w miłości (2009: 60).

Wyraźnie poruszony rozwojem rozmowy, Klaudiusz pyta o wymowę i stosowność sztuki. Odpowiedź Hamleta, która brzmi: „Nie, nie, żartują tylko, trują na żarty, ani śladu / Czegoś zdrożnego" (3.2.493-494), jego wyjaśnienie tytułu sztuki oraz wymierzone w Klaudiusza stwierdzenie, że tych, którzy mają czyste sumienie na pewno sztuka nie dotknie, sprawiają, iż król na chwilę wymownie zamyka oczy, by zaraz z niepokojem je przymrużyć, pokazując tym samym oznaki niepewności i zdenerwowania. Według Lawsona: „»Jadowity wywar « (1.5.861) ze słów, który Hamlet metaforycznie wlewa do uszu Klaudiusza, ulega wymieszaniu z wizualnym odegraniem morderstwa, powodując rozstrojenie i zatrwożenie u króla" (239). Moment, w którym Klaudiusz widzi wlewaną do uszu aktora-króla truciznę, jest dla niego dosłownym szokiem wizualnym.

Zeffirelli ukazuje otrucie króla przez brata jako widowisko bez słów, jednak wcześniej Hamlet wyjaśnia królowi relację łączącą postacie na scenie (stryj-bratanek). Poruszony inscenizacją morderstwa stryja, Klaudiusz powstaje, skupiając na sobie uwagę zebranych, po czym zaczyna zmierzać w kierunku sceny. Upuszczenie kielicha, dotknięcie ucha i jego chwiejny krok świadczą o wstrząsie, jaki spowodowała u niego obserwowana z uwagą pantomima. Na zakończenie król śmieje się obłąkańczo i w pośpiechu opuszcza komnatę, rozpaczliwie prosząc o światło. Hamlet zdoła jeszcze wykrzyknąć za nim, że króla przestraszył fałszywy alarm, a następnie wskakuje na scenę i zaczyna tańczyć oraz śpiewać wraz z aktorami.

Reżyser pokazuje też reakcję Gertrudy, której szeroko otwarte oczy wyrażają osłupienie, w jakie wprawia ją postępowanie syna. Matka uświadamia sobie, że harmonia panująca między Hamletem i Klaudiuszem to fikcja i złudzenie (Lawson, 1997: 240). Warto wspomnieć, że w tej adaptacji Hamlet staje się świadkiem spowiedzi Klaudiusza. Scenę ową reżyser umieszcza w zamkowej krypcie. Hamlet bardzo krótko obserwuje, jak stryj prawie konwulsyjne zmaga się ze swoim sumieniem w trakcie modlitwy. Książę rezygnuje z zamiaru zamordowania go i odchodzi na spotkanie z matką. 
W dramacie Szekspira i w adaptacji Zeffirellego konsekwencją konsternacji Gertrudy jest rozmowa z Hamletem w jej sypialni. Hamlet z werwą otwiera drzwi komnaty i wchodzi do niej, swawolnie wymachując mieczem, który towarzyszy mu także $\mathrm{w}$ tej scenie. Początkowa wymiana spojrzeń zmienia się w szermierkę słowną między matką i synem, która kończy się wymierzeniem policzka Hamletowi. Kpiarski ton głosu Hamleta zmienia się w potężny ryk, jaki bohater wydaje z siebie (w pewnym sensie powstrzymuje nim Gertrudę przed opuszczeniem sypialni). Wściekłe spojrzenie Hamleta i zwrócony w stronę Gertrudy miecz (gest o charakterze fallicznym) oznaczają męską dominację i postawę bojową, na którą królowa reaguje wołaniem o pomoc. Ukrywający się za olbrzymim arrasem Poloniusz zaczyna jej wtórować. Jest to jego ostatni krzyk, bo Hamlet od razu celuje mieczem w miejsce, skąd dobiega głos.

Ostatecznie więc matka i syn zostają w sypialni sami, a kolejna próba ucieczki Gertrudy wprawia Hamleta w coraz większą furię. Najpierw zmusza on królową do przyjrzenia się portretom jej mężów, przy czym jeden z nich nosi na swojej szyi Hamlet, a drugi zawieszony jest na szyi Gertrudy. Zeffirelli sugeruje, że widok zmarłego męża, w połączeniu z charakterystyką portretów, jakiej dokonuje Hamlet, staje się torturą dla jej oczu i uszu. Starając się gwałtownie odwrócić od syna, matka zostaje uwięziona trzymanym przez Hamleta łańcuchem, do którego przymocowany jest portret. Po chwili Hamlet staje się seksualnie agresywny, wykrzykując obelżywe słowa i symulując stosunek płciowy z matką. Percepcyjne doświadczenia Gertrudy są $\mathrm{w}$ tym fragmencie niezwykle intensywne, balansujące na granicy między tym, co dozwolone, a tym, co zakazane. Granica ta całkowicie się zaciera, gdy matka ucisza Hamleta namiętnym pocałunkiem.

Z interwencją przybywa zjawa ojca, która powoduje zmianę w zachowaniu Hamleta. Wizualnie i słuchowo postrzegany przez księcia duch pozostaje niewidzialny i niesłyszalny dla Gertrudy. Hamlet kieruje się jego zaleceniem, by dzięki rozmowie z matką pomógł jej odróżnić grzeszną drogę postępowania od moralnie właściwej. Hamlet chwyta matkę za twarz i z pozycji lustrzanego odbicia przemawia do niej, jednocześnie spoglądając jej prosto w oczy. Poprzez zbliżone ujęcie Zeffirelli oddaje stan wewnętrznego zagubienia bohaterki, jej zapłakane oczy i drżący głos, kiedy wypowiada kwestię potwierdzającą owo rozdarcie. Jak zauważa Lawson, Gertruda „wydaje się wizualnie zestarzeć podczas tej sceny, a biorąc pod uwagę »sztyletowate« słowa Hamleta, mają [one] na celu kłuć jej sumienie na tyle, by dłużej nie lekceważyła swojej przeszłości" (1997: 241). Z kolei dla Hamleta uprzednia frustracja, związana z wizualnym i audialnym oddziaływaniem matki, przechodzi w fazę erotyczną, znajdującą ujście w pozorowanym gwałcie. Ani u Branagha, ani u Almereydy scena spotkania w sypialni Gertrudy nie obróci się w tak granicznie pobudzającą zmysły bohaterów konfrontację wzrokową i słucho- 
wą. Niebezpieczne dla zmysłów - gdyż mogące wymknąć się spod kontroli - spotkanie matki z synem $\mathrm{w}$ adaptacji Zeffirellego zostaje sfinalizowane widokiem Gertrudy przyglądającej się podobiźnie zmarłego męża. Krótkotrwałą refleksję przerywa wtargnięcie Klaudiusza i pospieszne schowanie portretu przez Gertrudę. Skazana na ciągłą wzrokowo-słuchową obecność mężczyzn, bohaterka podlega kulturowej ocenie wyznaczanej przez męskie spojrzenie oraz głosowość.

Sieć intryg w Hamlecie Branagha również bardzo ściśle wiąże się z organizacją filmowej przestrzeni elsynorskiej. Reżyser zaprezentował swoją filmową strategię poprzez ukazanie gąszczu podstępów, jakich dopuszczają się Szekspirowskie dramatis personae. Kołos stoi na stanowisku, że w jego reżyserskiej wizji

[w]ielki Elsynor jest doskonałym tłem dla podkreślenia karłowatości ludzkiego ducha. Biel pałacowych ścian i nieskazitelne powierzchnie luster sprawiają, że moralny brud, niszczący dwór i kraj, zestawiony z symboliką barw i przestrzeni, staje się niemal widoczny (2007: 166).

Branagh preferuje perspektywę horyzontalną, tutaj umieszczając głównego bohatera, i na tym samym poziomie lokując główne wątki szpiegowskie, oparte o praktyki wzajemnego podsłuchiwania i podpatrywania. Galeria luster ułatwia obserwowanie, zaś labirynt przejść między pomieszczeniami, posiadającymi ogromną liczbę drzwi, wpływa również na możliwości ograniczenia postrzegania słuchowego.

Carol Chillington Rutter, autorka Enter the Body: Women and Representation on Shakespeare's Stage (2000), tak podsumowuje krajobraz elsynorski u Branagha:

Od podłogi po sufit otoczona lustrami sala, w której osadzono znaczną część akcji, jest samowielbiącą się komnatą zwierciadlaną, gdzie, jak się okazuje, lustra w sposób anachroniczny funkcjonują jako drzwi prowadzące do pomieszczeń. Nieprawdopodobne, lecz pokoje Hamleta leżą dokładnie za jednymi z tych drzwi; a za innymi - sypialnia Ofelii i później jej cela, wyściełana gąbką (46).

Scena zaaranżowanego spotkania Ofelii z Hamletem stanowi jeden z wyraźniejszych przykładów na wykorzystanie owego architektonicznego labiryntu, złożonego z ogromnej liczby luster i drzwi.

Doświadczenia zmysłowe kształtowane są nie tylko przez same narządy postrzegania, lecz przez wymienione wyżej dodatkowe elementy konstrukcyjne komnaty. Branagh umieszcza Klaudiusza i Poloniusza za jednym z podwójnych luster w głównej sali pałacowej. Ofelię pozostawia przyczajoną w kącie komnaty, po to, by w odpowiednim momencie odegrała swoją rolę, zgodnie z instrukcją ojca. Inaczej niż u Zeffirellego, spisek nie od razu zosta- 
je wykryty przez Hamleta. Bohater wchodzi do lustrzanej komnaty, w której z każdego zwierciadła spogląda na niego nie tylko jego własne odbicie; za każdym ze zwierciadeł mogą kryć się oczy innej postaci. Specyfiką sali pałacowej jest poza tym potężna przestrzeń akustyczna, w której każde drzwi, niczym otwory wlotowe/wylotowe, stwarzają możliwości dodatkowej modulacji dźwięku.

Początkowo nieświadomy spisku bohater zaczyna wygłaszać monolog „Być albo nie być”, który kieruje w stronę jednej z powierzchni lustrzanych. Ponieważ lustro pełni także funkcję drzwi, umożliwia jednocześnie podsłuchiwanie. Branagh tak skonstruował tę scenę, by akurat za tą konkretną odbijającą powierzchnią schowane były dwie pary inwigilujących Hamleta oczu i dwie pary nadstawionych uszu. Crowl opisuje filmową technikę reżysera, analizując możliwości, jakie stwarza zwierciadlana przestrzeń komnaty:

\footnotetext{
W zwodniczo podstępnym ujęciu kamera wpatruje się znad lewego ramienia Hamleta, pochwyciwszy jego pełne odbicie w lustrzanych drzwiach. Podczas przemowy kamera powoli wykonuje zbliżenie, aż Hamlet staje się obecny w ujęciu tylko jako odbicie, jak gdyby próbował odkryć w owym „narcystycznym” innym jakąś wskazówkę dla swojego ostatniego odkrycia, dotyczącego rozbieżności pomiędzy: pozorem a rzeczywistością, lojalnością a zdradą, oszustwem a uczciwością (2003: 142).
}

Pewnym tropem staje się dla bohatera spotkanie z Ofelią, bo stanowi ono nie tylko przełom w relacji między nimi, ale też przyczynia się do zdemaskowania kolejnych osób uwikłanych w sieć intryg dworskich. Wyłaniający się z tej sceny obraz kultury percepcyjnej przedstawia, z jednej strony, patriarchalne zniewolenie kobiecych zmysłów, z drugiej zaś - obsesyjną potrzebę sprawowania kontroli nad jakimikolwiek przejawami przewagi percepcyjnej między mężczyznami.

Odmiennie niż w adaptacji Zeffirellego, Hamlet Branagha najpierw wydaje się podchodzić do Ofelii bez żadnych uprzedzeń i podejrzeń o uczestnictwo w zasadzce na niego. Ich rozmowa przybiera charakter naturalnego spotkania stęsknionych za sobą kochanków (czułe objęcia i pocałunki), aż do momentu, gdy Ofelia oddaje Hamletowi jego listy, spoglądając mu prosto w oczy. Dla Hamleta stanowi to sygnał, że ukochana nie podjęła tej decyzji autonomicznie. W interesujacy sposób Branagh ustawia bohaterów naprzeciwko siebie, jak gdyby przyglądali się sobie niczym w zwierciadle, jak gdyby byli owym odbiciem lustrzanym wystraszeni i zaskoczeni.

W geście odtrącenia powracających do niego listów Hamlet powstrzymuje dłoń Ofelii przed ich zwróceniem. Jednocześnie zmienia się ton jego głosu - z czułego i pełnego ufności przeistacza się w podejrzliwy i przesłuchujący. Agresywna przemowa księcia i jego wyznanie, że kiedyś kochał Ofelię, sprawiają, iż gorzkie słowa zaczynają oddziaływać przeszywająco na słuch bohaterki. Choć obydwoje mają łzy w oczach, żadne nie wyjawia przyczyn swoje- 
go zachowania. Postrzeganie Hamleta jest uzależnione od opowieści ducha. Zmysły Ofelii są kulturowo podległe rygorowi posłuszeństwa w stosunku do ojca. Nawet w momencie, gdy krótki dźwięk dobiegający zza jednego z luster zdradza obecność jeszcze kogoś na sali, Ofelia nie odkrywa tożsamości szpiega. Na pytanie, gdzie jest jej ojciec, z wyraźnym smutkiem w oczach odpowiada, że Poloniusz przebywa w domu. Hamlet reaguje na kłamstwo Ofelii między innymi rozpaczliwym zamknięciem oczu oraz głębokim załamaniem głosu. Jego oczy widzą piękno, lecz uszy słyszą kłamstwa. Bohater zasłania oczy obiema rękami i wypowiada słowa pożegnania. Ofelia widząc załamanie księcia, chwyta go za dłonie, jednak tym ruchem powoduje wybuch furii Hamleta. Ten bowiem agresywnie łapie ją za ręce i zaciąga do pierwszego z luster w sali. Powtarzając ten gest przy kilku innych, jednocześnie nerwowo zagląda za lustrzane drzwi.

Hamlet oskarżycielskim tonem zarzuca Ofelii kobiece nieprawości związane z maskowaniem się pod różnymi powłokami, między innymi pod powłoką makijażu. Brutalnie chwyta ją za twarz i przystawia do lustra, za którym kryją się Poloniusz i Laertes. Z ich perspektywy twarz Ofelii wygląda na zniekształconą. Oglądają jej rozpłaszczony policzek, a stojący za jej plecami Hamlet wydaje się na ich oczach niemalże używać seksualnej przemocy. Hamlet Branagha w brutalny sposób obnaża zatem swoiste intrygi percepcyjne na dworze, ich brzydotę i amoralność, przy czym wykorzystuje do tego celu Ofelię. Bohaterka zostaje uwięziona w spojrzeniu, z każdej ze stron lustra jest bowiem obserwowana przez mężczyzn. Niewątpliwie jest też werbalnie znieważona.

Klaudiusz i Poloniusz orientują się, że Hamlet zamierza otworzyć zwierciadlane drzwi i odkryć ich obecność. Uprzedzają więc jego ruch, ewakuując się z pomieszczenia. Bohater słyszy jedynie zamykanie lustra od strony wewnętrznej, by po ucieczce Poloniusza i Klaudiusza zwierciadło wyglądało na zwyczajne drzwi. Ofelia zaś zostaje porzucona przez Hamleta w przejściu przez lustrzane drzwi. Nie jest to jedyny moment, kiedy Branagh portretuje leżącą lub na wpół leżącą Ofelię. Podobne ujęcia pojawiają się w retrospekcjach, gdzie reżyser ukazuje sceny miłosne między Ofelią i Hamletem, w scenie szaleństwa, gdy bohaterka sama rzuca się na posadzkę pałacową i zaczyna parodiować ruchy kopulacyjne, oraz w krótkim ujęciu martwej, zatopionej w wodzie Ofelii. Z wyjątkiem tej ostatniej sceny, w pozostałych zarysowuje się związek pomiędzy symulowanymi doświadczeniami percepcyjnymi bohaterki a jej filmowymi poziomymi ujęciami. Pozycja leżąca odsyła bowiem do doznań seksualnych Ofelii - od erotycznie satysfakcjonujących po niemalże masochistyczne.

W ostatnich słowach książę wysyła ją do klasztoru, by po chwili zniknąć za kolejnymi drzwiami (te z kolei wyglądają jak ściana komnaty). Ofelia cały swój żal zawiera w monologu, którego zostaje pozbawiona jej imienniczka 
w skróconych wersjach Zeffirellego i Almereydy. Drżącym i łkającym głosem bohaterka tą wypowiedzią przestawia swój punkt widzenia. Jak podaje James E. Hirsch, autor Shakespeare and the History of Soliloquies, płynące z solilokwium

\begin{abstract}
słowa nie są adresowane ani do ojca, ani do króla, mimo że Ofelia wie, iż te postacie pozostają w zasięgu słuchu. Nie jest także prawdopodobne, że uważnie pilnuje, aby te słowa nie zostały usłyszane przez postacie stojące z boku. Ofelia nie ma w zwyczaju utrzymywać sekretów przed ojcem, a jej słowa nie odkrywają żadnych tajemnic. Jest tak przytłoczona emocjami, że po prostu daje upust swoim uczuciom w postaci przemowy, nie troszcząc się o to, kto słyszy jej monolog (2003: 155).
\end{abstract}

W adaptacji Branagha jedynym sekretem Ofelii wydaje się seksualna relacja z Hamletem, a nie same miłosne wyznania, o których wspomina w solilokwium. Tuż po jego zakończeniu w pokoju pojawiają się Klaudiusz z Poloniuszem, który podnosi „upadłą” Ofelię z podłogi i ojcowskim gestem przytula ją do siebie. W porównaniu z Poloniuszem Zeffirellego, kanclerz Branagha jest ukazany jako znacznie mniej bezwzględny i bardziej troskliwy ojciec. Poloniusz nie rezygnuje za to $\mathrm{z}$ dalszego konszachtowania z Klaudiuszem, przystając na jego plan wysłania Hamleta do Anglii. Dzieje się to w obecności milczącej i roztrzęsionej Ofelii, która ma też szanse usłyszeć wypowiedź Klaudiusza, że „szaleństwo, gdy się wielkim zdarzy, / Wymaga nie swobody, ale straży” (3.2.229-230). W przyszłości także król wyda polecenie czuwania nad obłąkaną Ofelią. Zanim jednak bohaterka postrada zmysły, Hamlet ponownie spotka się z nią, zastawiając zasadzkę, która w wersji Branagha przybiera formę taką jak u Szekspira, czyli inscenizacji teatralnej.

Branagh urządza podwójne widowisko z „Pułapki na myszy”. Składa się na nie wystawienie samej sztuki, jak i popis aktorstwa Hamleta, odgrywającego niebezpiecznego błazna-komentatora. W żadnej z omawianych adaptacji Hamlet tak intensywnie nie wykorzystuje własnych zdolności wizualno-audialnych do wywołania granicznych doznań sensualnych u odbiorców, jak u Branagha. Reżyser obdarza Hamleta niemalże absolutną przewagą oraz nieograniczonymi możliwościami manipulacyjnymi w zakresie zmysłu wzroku i słuchu, czyniąc go „mistrzem ceremonii”. Symulowane pomieszanie zmysłów bohatera doprowadzone zostaje w tej scenie do perfekcji i pozwala mu na kuglarskie sztuczki, wykorzystujące potencjał tkwiący w obrazach i dźwiękach. Niczym w soczewce, w tej scenie skupiają się wszelkie lęki i obsesje dotyczące kontroli zachowań w ramach dziewiętnastowiecznej kultury percepcyjnej, w której osadzona jest akcja adaptacji. Filmowe konstrukcje widzenia i słyszenia $\mathrm{w}$ tej scenie dobitnie podkreślają znaczenie zmysłów jako narzędzi kontroli i zdobywania informacji o innych.

Scenę umieszczono w sali tronowej, o szczególnych walorach wizualnych oraz akustycznych i z tego powodu sprzyjających również podglądaniu i podsłuchiwaniu. Jak podaje Hatchuel: 
Ta zamknięta i prostokątna przestrzeń odsłania dośrodkowe i teatralne cechy, biorąc pod uwagę ułożone stronami rzędy, wyższe piętra z siedzeniami i wiszące balkony. Postaci wchodzą i wychodzą przez sekretne drzwi umieszczone z każdej strony komnaty (2004: 98).

Warto wspomnieć, że działający w konspiracji z Hamletem Horacjo otrzymuje zadanie obserwowania króla przez lornetkę z jednego z balkonów w sali tronowej.

Główny reżyser przedstawienia wprowadza „duszną atmosferę sensoryczną", jeszcze zanim zostanie ono odegrane na scenie. Jego wymiana zdań z Klaudiuszem, Gertrudą i Ofelią (prowadzona zarówno ze sceny, jak i z widowni) powoduje, że oczy i uszy wszystkich zebranych dworzan zwracają się ku parze królewskiej oraz w stronę znajdującej się obok niego Ofelii. Hamlet używa podniesionego głosu; jego wypowiedzi są napastliwe i drwiące, Wykrzykiwane, albo wprost do ucha Ofelii, albo w stronę, siedzącej powyżej w loży królewskiej, Gertrudy. Są to aluzje seksualne oraz podteksty mające związek z rychłym zamążpójściem matki. Zaskoczona i skrępowana jego zachowaniem Ofelia stara się wymijającymi odpowiedziami i uciekającym wzrokiem uniknąć konfrontacji z Hamletem. Gertruda tylko przez chwilę zdradza, że uwagi syna są dla niej obraźliwe. Taką strategią filmową Branagh powtórnie podkreśla konieczność ekspozycji prywatnych zachowań rodziny królewskiej na forum publicznym. Hamlet staje się prowokatorem słyszalnych dla wszystkich reakcji matki i stryja, którzy w miarę rozwoju wydarzeń w trakcie przedstawienia, zaczynają się niewygodnie czuć na zajmowanych przez siebie, „przyprawiających o zawrót głowy miejscach siedzących” (McEvoy, 2006: 108).

Po pantomimicznej części przedstawienia, którą Klaudiusz wydaje się ignorować, następuje część teatralna, oddziałująca jednocześnie na wzrok i słuch odbiorców. Branagh koncentruje się na ukazaniu reakcji percepcyjnych pary królewskiej, przy czym kamera kilkakrotnie pokazuje też reakcje Ofelii, wychwytując ukradkowe spojrzenia Poloniusza oraz zaciekawienie i żądność sensacji na twarzach zebranych dworzan. Scena, w której aktorka-królowa wypowiada kwestie o trwałości kobiecej miłości, porusza tak samo zmysły Gertrudy, jak i Ofelii. Jednak najbardziej wstrząśnięty jest Klaudiusz, co widać w zastosowanych przez Branagha cięciach między aktualnie rozgrywającą się akcją a retrospekcyjnymi wspomnieniami Klaudiusza. Wizualizuje on moment zabójstwa brata, który pokrywa się z odtwarzanym na scenie „lustrzanym odbiciem" tego zdarzenia. W kulminacyjnym momencie Klaudiusz powstaje i wraz z przerażonym jego nagłą reakcją dworem opuszcza komnatę.

Po tym wydarzeniu triumfujący Hamlet $\mathrm{z}$ adaptacji Branagha ma szansę uczestniczyć w spowiedzi Klaudiusza, nie przez przypadek umieszczonej w konfesjonale, gdzie ukrywający się po stronie spowiednika Hamlet „wsłuchuje się” w sumienie stryja. W pewnym momencie nawet „oczami wyobraź- 
ni" umieszcza w kratce konfesjonału sztylet, który wbija się prosto w ucho Klaudiusza. Kamera sugestywnie pokazuje tryskającą prosto $\mathrm{z}$ ucha krew, by za chwilę jednak bohater zrezygnował z pomysłu zgładzenia stryja w trakcie „świętej” spowiedzi.

Tak jak w sztuce Szekspirowskiej, bohater ma też okazję przeprowadzić kluczową dla relacji z Gertrudą rozmowę w jej prywatnej komnacie. Jak twierdzi Burnett w artykule „»The Very Cunning of the Scene«: Kenneth Branagh's Hamlet”: „W tej scenie, w rzeczywistości, wytworzone voyeurystyczne wrażenie jest wzmocnione przez komnatowe, ścienne, w stylu Tiepolo, malowidła podsłuchiwaczy, przechylonych przez balustrady, by obejrzeć zdarzenie o wyraźnie fascynującej treści" (1997: 80). Prawdziwym szpiegiem, ukrytym za arrasem i nastawionym na odkrycie motywów postępowania Hamleta, pozostaje Poloniusz ${ }^{2}$.

Hamlet pojawia się w sypialni matki, wchodząc przez drzwi, będące jednocześnie fragmentem ściany. Postacie od razu nawiązują mało przyjazny kontakt wzrokowy, a ich podniesione głosy sugerują bojowe nastawienia, wyrażone poprzez wstępną, natarczywą grę słów pomiędzy nimi. Próbę opuszczenia sypialni przez Gertrudę udaremnia Hamlet, który niespodziewanie chwyta matkę za szyję, sadza na fotelu i zapowiada, że pokaże jej zwierciadło, w którym ujrzy ona najgłębszą część swojej duszy. Gertruda wzywa pomocy, co z kolei powoduje reakcję ukrytego świadka zdarzeń, czyli Poloniusza, wydającego okrzyk zza arrasu. W wersji Branagha szpieg ginie od ciosów, jakie Hamlet zadaje mu kilkakrotnie szpadą, mierząc do szamoczącej się za kotarą postaci.

Dalszej części agresywnej rozmowy przewodzi Hamlet. Rzucając matkę na łóżko i stosując retorykę spowiedniczą, zaczyna przekonywać ją do zmiany perspektywy. Do tego celu wykorzystuje nie tylko percepcję słuchową matki, lecz także jej postrzeganie wzrokowe. Zestawia miniatury zdjęć ojca i stryja. Kamera pokazuje, jak Gertruda przez chwilę wpatruje się w podobiznę zmarłego męża, nie patrząc na drugie zdjęcie. Zarówno słowa, jak i obrazy oddziałują silnie na zmuszoną do przeprowadzenia rachunku sumienia matkę - domniemaną grzesznicę. Gertruda błagalnie prosi, by Hamlet nie ranił jej uszu słowami, ostrymi niczym sztylety. Jednak to nie rozpaczliwa prośba matki, lecz pojawienie się ducha ojca uspokaja Hamleta. Niedostrzeżona przez „zaślepioną” Gertrudę zjawa wkrótce odchodzi, ale zaleca Hamletowi, by nie ustawał w przemawianiu do matki.

Ostatni fragment sceny rozgrywa się na sofie, na której matka i syn siedzą obok siebie, tak że Hamlet ma możliwość nie tylko ciągłej obserwacji oczu Gertrudy, ale także bezpośredni wpływ na jej słuch. Zachęcając królową do wyznania grzechów i wstrzymania się od kontaktów seksualnych z Klau-

\footnotetext{
${ }^{2}$ Burnett uważa, że scena wizyty Hamleta w sypialni Gertrudy należy do jednej z „filmowych sekwencji spowiedniczych" (1997: 79).
} 
diuszem, Hamlet odwołuje się do kapłańskiego moralizowania, prowadzącego do żalu za grzechy i możliwości odkupienia win. Ich pożegnanie zostaje przypieczętowane krótkim uściskiem, podczas którego kamera pokazuje uzewnętrznione w wyrazie oczu obawy Gertrudy. Spotkanie z Hamletem wydaje się stanowić dla niej inwazję przykrych doświadczeń audialnych i wizualnych, co potwierdzają wydawane przez kobietę paniczne westchnienia oraz łkanie tuż po wyjściu Hamleta.

Spiski i manipulacje, składające się na sieć intryg percepcyjnych, nabierają jeszcze innego kształtu w adaptacji Almereydy. Ulokowanie akcji dramatu w Nowym Jorku z przełomu XX i XXI wieku, a większości scen na najwyższych piętrach w hotelu Elsynor, powoduje, że choć rozgrywają się one wysoko ponad ulicami miast, to jednak postacie prowadzą „rozgrywki percepcyjne” na płaszczyźnie horyzontalnej; wzajemna obserwacja i przysłuchiwanie się rozmowom innych odbywa się w ramach „tej samej kondygnacji”. Niespotykanym zabiegiem w innych adaptacjach Hamleta jest technologicznie „zapośredniczone szpiegowanie" (Hatchuel, 2004: 31), a więc niebezpośrednie percepcyjne uczestnictwo w tych czynnościach, które pozwalają na zdobycie informacji o innych bohaterach, o ich planach oraz działaniach.

W Hamlecie Almereydy ciągłe przemieszczenia postaci, zmiana scenerii i przechodzenie na zmianę z przestrzeni otwartych do zamkniętych, ma znaczenie dla filmowych reprezentacji zmysłów. Chodzi głównie o dodatkowe bodźce dla zmysłów oraz ich wpływ na zachowania bohaterów. Jest to zatem zgiełk uliczny, skontrastowany z wyciszonym pokojem Hamleta, albo wypełniona światłami kamer i fleszy sala konferencyjna w zestawieniu z pustymi korytarzami hotelu Elsynor. Ani Zeffirelli, ani Branagh nie podchodzą tak odważnie do kwestii zmian scenerii i nagłego przenoszenia w nie bohaterów. Koncentrują raczej akcję w granicach pałacu, umieszczając bohaterów w różnych zakamarkach zamku lub znacznie rzadziej w jego sąsiedztwie. Zdaniem autora Shakespeare: The Basics, Seana McEvoya:

\footnotetext{
Większośćakcji rozgrywasię w wąskich, ograniczonych pomieszczeniachalbow niespokojnych i przejściowych przestrzeniach, które nie są, ani tym, ani innym miejscem; w korytarzach, przejściach, przypominających kaniony, na ulicach, otoczonych ogromnymi biurowcami, na balkonach o wielu kondygnacjach, sięgających wysoko w powietrze. Poczekalnie i korytarze znacznie się wyróżniają; postaci są często ukazane, jak wsiadają lub wysiadają z taksówek i limuzyn, albo jak wchodzą lub wychodzą z lotniskowych terminali (2006: 116).
}

Scena spotkania Hamleta z Ofelią, dzięki przemieszczeniu bohaterki z apartamentu Klaudiusza i Gertrudy do mieszkania Hamleta, odsłania nowe oblicze praktyk inwigilowania w Hamlecie. Ofelia Almereydy dosłownie staje się narzędziem podsłuchu, bo przed wysłaniem jej z misją szpiegowską Poloniusz wyposaża córkę $\mathrm{w}$ aparat podsłuchowy. W kompromitujący dla 
dziewczyny sposób, Poloniusz, na oczach nowych władców korporacji „Dania”, „okablowuje” Ofelię. Interesujące, że Almereyda w ogóle pozbawia bohaterkę jakiejkolwiek możliwości reakcji werbalnej. Na stwierdzenie Gertrudy, by to uroda Ofelii „przyczyną była Hamletowych dziwactw” (2.1.44), a jej cnota przywiodła go do poprzedniego stanu, Ofelia reaguje zaciśnięciem ust. Reżyser pokazuje zbliżenie jej zapłakanej twarzy. Nawet jej płacz jest bezdźwięczny, co podkreśla tłumienie emocji przez bohaterkę.

Warto tutaj wspomnieć o wcześniejszej sytuacji, rozgrywającej się także w apartamencie Klaudiusza i Gertrudy, w której bohaterka w znamienny sposób powstrzymuje emocje. Nie mogąc znieść ujawnienia jej prywatnej korespondencji od Hamleta, Ofelia wizualizuje skok do basenu, zaglądając w lustro błękitnej wody. Zatopienie w wodzie zagłusza głos Poloniusza, który kojarzy się Ofelii głównie z upomnieniami, strofowaniem i brakiem zrozumienia. Chwilowe wyzwolenie, spowodowane wyobrażeniem sobie skoku do basenu, to kolejna zapowiedź wodnej śmierci Ofelii; ucieczki od męskich głosów i powrotu do pierwotnej ciszy, niczym do łona matki. Odwołania do metaforyki związanej z ciałem matki są popularne przede wszystkim w interpretacjach feministycznych.

Ofelia Almereydy wkracza w osobistą przestrzeń Hamleta, a przekraczając próg jego mieszkania, świadomie wnosi do niego aparat szpiegowski. Warto zauważyć, że w tym krótkim fragmencie filmowym, to właśnie Ofelia staje w centrum zainteresowania kamery Almereydy. Zachodzi więc zjawisko kompensowania nieobecności werbalnej bohaterki na rzecz jej wizualnej bytności na ekranie. „Okaleczony” pod względem jej kobiecych wypowiedzi scenariusz adaptacji Hamleta z 2000 roku, otrzymuje „protezę” w postaci częstego obrazowania zachowań pozawerbalnych i mimiki twarzy Ofelii ukazywanej w zbliżeniach.

Reżyser przedstawia w sposób bardzo oszczędny pod względem gestów powitalnych początek spotkania Hamleta i Ofelii. Ujęcie koncentruje się na siedzącej przy stole dziewczynie, natomiast książę zajmuje nieco oddalone miejsce na parapecie okna. Bohaterka przystępuje do wypełnienia swojej misji, rozpoczynając od zwrócenia Hamletowi jego listów, które wyjmuje z kartonowego pudełka. Almereyda eksponuje filmowe reprezentacje wzrokowe i słuchowe Ofelii przez skoncentrowanie się na reakcjach jej zmysłów. Hamlet pozostaje nieco w cieniu, choć to on zadecyduje o związku z Ofelią. W opinii Alessandra Abbate, autora „»To Be or Inter-Be«: Almereyda's End-of-millenium Hamlet", Ofelię i Hamleta łączy zainteresowanie technologicznymi „przedłużeniami ciała” - aparatem i kamerą - i ich możliwościami symulowania rzeczywistości:

Ich miłość narodziła się ze wspólnej fascynacji reprodukowanymi obrazami, a ich związek oparty jest na odrzuceniu słów jako środka komunikacji i wiedzy. Tych dwoje mło- 
dych kochanków, którzy dialog zastąpili wywoływaniem fotografii i cyfrowym postinscenizowaniem, niewiele ze sobą rozmawia, a jedyna bliska wymiana zdań, jaką mają [...], jest [ich] smutnym pożegnaniem (2004).

Początkowo bohaterka nie utrzymuje żadnego kontaktu wzrokowego z Hamletem i tylko przez chwilę spogląda na niego, wypowiadając kwestię o ulotności znaczenia wcześniejszych przysiąg mężczyzny. On z kolei od początku uważnie obserwuje zachowanie dziewczyny, by ostatecznie zapytać o jej uczciwość. Zakłopotana Ofelia nie wie, co odpowiedzieć, zaś Hamlet zmienia temat rozmowy i oznajmia że, wyznając, iż kiedyś ją kochał, nie mówił prawdy. Bohaterka wbija wzrok w blat stołu i reaguje stwierdzeniem, że została oszukana. W tej scenie uzyskuje potwierdzenie ostrzeżeń ojca i brata, których wcześniej nie chciała zaakceptować. Nie wiedząc, dlaczego Hamlet wypowiada raniące ją słowa, nadal jednak łaknie kontaktu z nim.

Hamlet przełamuje dystans między nimi, przysiadając się do Ofelii. Jednocześnie zaczyna dotykać jej twarzy i ramienia, tłumacząc, by nie wierzyła żadnemu mężczyźnie. Ofelia poddaje się jego pocałunkom, chłonie każde jego słowo i wpatruje się dziecięco naiwnym wzrokiem w oczy kochanka. W pewnym momencie Hamlet odkrywa zamontowane na jej ciele urządzenie z mikrofonem, ukryte pod bluzką. Demaskując podstęp, zrywa przyczepiony mikrofon i zasłaniając go, pyta gdzie jest Poloniusz. Hamlet nie pozwala odpowiedzieć Ofelii i zamiast tego wykrzykuje do mikrofonu, by jej ojciec odgrywał błazna we własnym domu. Odpycha kobietę, zrzuca ze stołu jej listy i w gorzkim komentarzu wysyła Ofelię do klasztoru. Kamera koncentruje się na rozpaczającej bohaterce.

Następne ujęcia reżyser poświęca Ofelii: dziewczyna jedzie na rowerze do swojego mieszkania, by tam dokonać symbolicznego rozstania z przeszłością. Paląc zdjęcia Hamleta, wysłuchuje oszczerstw na swój temat, które nagrywa on na "sekretarkę” jej telefonu. Pomimo braku bezpośredniego kontaktu między nimi, Hamlet nadal ma możliwość oddziaływania na słuch Ofelii. Abbate twierdzi, że „[w] momencie, gdy jego symulowany głos dociera do Ofelii, Hamlet znika. Poprzez wydanie krótkiego dźwięku telefon wydaje wyrok o zakończeniu ich romansu" (2004). Bezcielesny, telefoniczny głos księcia jest bardziej widmowy niż przekaz ducha adresowany do Hamleta przez postać przypominającą jego ojca. Jeśli powołać się na opinię Burnetta, który twierdzi, że w Hamlecie Almereydy technologia ma negatywny wpływ na proces komunikacji międzyludzkiej (2003: 54), to okazuje się, iż w przypadku tej sceny uniemożliwia ona Ofelii natychmiastową i niezapośredniczoną reakcję. Odpowiedź bohaterki to bezdźwięczny płacz i rezygnacja z jakiejkolwiek formy językowego wyrażenia swojego bólu po rozstaniu. „Przemawiają” jedynie mokre od łez oczy Ofelii, która „kochała nie tylko Hamleta z krwi i kości, ale również jego celuloidową reprodukcję" (Abbate, 2004). 
Zniszczenie zdjęć Hamleta stanowi próbę „oczyszczenia” pamięci dziewczyny ze wspomnień-obrazów o nim. Znamienne jest to, że bohaterka nie kasuje nagrań telefonicznych.

Zarówno pułapka na zmysły, zastawiona na Hamleta, jak i przez Hamleta, ma w adaptacji Almereydy ścisły związek z manipulacją zmysłami przez wykorzystanie do tego celu osiągnięć technologicznych kultury wzrokocentrycznej. Reżyser odchodzi zatem od tradycyjnego przedstawienia tej sceny, podążającej za Szekspirowską tradycją teatralną, na rzecz ukazania filmu-w-filmie. Bohater konstruuje go w formie kolażu, składającego się głównie ze scen z innych filmów. Jak podaje Abbate w artykule „The Text within the Text, the Screen within the Screen: Multi-Layered Representations in Michael Almereyda's Hamlet and Baz Luhrmann's Romeo + Juliet", są to następujące obrazy:

wygenerowane przez komputer animacje rozkwitających i więdnących kwiatów, fragmenty filmów niemych, historycznych i pornograficznych, ujęcia z filmów edukacyjnych, ukazujące szczęśliwe życie rodzinne z lat pięćdziesiątych, różne telewizyjne i filmowe klipy oraz inny, kolorowy i biało-czarny materiał multimedialny [...] (2007: 379).

Złożone w całość, mają one opowiedzieć historię doprowadzającą do otrucia jego ojca i grzesznego związku matki ze stryjem. Ciekawe, że „Pułapka na myszy" przybiera formę przekazu wizualnego, wspartego klasyczną ścieżką dźwiękową - partyturą Czajkowskiego (379). W artykule „»Images, Images, Images «: Contemporary Landscape in Michael Almereyda's Hamlet" Joana Owens pisze, że skonstruowanie przez Hamleta pastiszowej wersji „Pułapki na myszy" powoduje, że bohater przechodzi od biernego i refleksyjnego oglądania własnego video-pamiętnika oraz innych przekazów filmowych, w kierunku aktywnego manipulowania obrazami. Hamlet przechodzi od kontemplacji ku działaniu (2003: 25).

W trakcie projekcji autorskiego filmu „Pułapka na myszy” w hotelowej minisali kinowej Hamlet zasiada obok Ofelii, daleko za sobą mając Klaudiusza i Gertrudę (zajmują miejsca w na końcu pomieszczenia). W sali projekcyjnej zbiera się niewielka grupa osób, przy czym Almereyda dokonuje znaczącej zmiany poprzez wyłączenie z grupy odbiorców Poloniusza. Hamlet często odwraca się w stronę Klaudiusza, obserwując jego reakcje, podobnie jak będący z nim w zmowie Horacjo. Rozpoznanie podejrzanych zachowań Klaudiusza doprowadza Hamleta do wniosku, że przyznał się on do popełnienia zbrodni. Takim sygnałem stają się dla bohatera zmiany w wyrazie twarzy stryja, a przede wszystkim jego ucieczka na widok filmowego czarno-białego wizerunku króla, stojącego przed lustrem i zakładającego koronę. Oczy Klaudiusza zdradzają przerażenie, a jego wołanie o światło zbiega się z zakończeniem projekcji filmu Hamleta. Jak się okaże, poruszony wizualnym prze- 
kazem nowy szef korporacji „Dania”, wyzna swoje winy w trakcie podróży limuzyną po ulicach miasta, zaś świadkiem jego spowiedzi będzie udający szofera - Hamlet. Drugi „świadek” wyznawania win przez Klaudiusza to mały monitor telewizyjny, niewzruszenie emitujący różne obrazy.

Strukturalną konsekwencją zasadzki Hamleta jest spotkanie z Gertrudą w jej prywatnej przestrzeni hotelowej. Zgodnie z wcześniejszymi ustaleniami między nią i Poloniuszem, ten ostatni ukrywa się w lustrzanej szafie, aby podsłuchać rozmowę z Hamletem. Almereyda reorganizuje tekstualną część Szekspirowskiego scenariusza dramatu, sprawiając, że wypowiedzi Gertrudy zostają znacznie ograniczone i zastąpione wizualnymi reakcjami tej postaci. Staje się to szczególnie wyraźne w omawianej scenie, w której wybuch agresji werbalnej Hamleta, skierowany wprost do matki, paraliżuje jej odzew językowy. Almereyda pomija też istotny wątek Hamleta w rozmowie dotyczącej zestawienia dwóch wizerunków mężów Gertrudy. Te kwestie zostają przeniesione do innej, wcześniejszej sceny, w której bohater samotnie kontempluje video-obrazy ukazujące zmarłego ojca.

Przeszywający dźwięk sygnalizujący nadejście Hamleta to dźwięk natarczywie wciskanego przez niego dzwonka u drzwi. Wmaszerowuje on do pokoju matki lekceważąco odwrócony do niej plecami. Bohater od samego początku stosuje „sensoryczną przemoc” w stosunku do matki, tzn. wpływając na jej zmysły własnymi. Po krótkiej wymianie zdań, w której Hamlet stara się upomnieć matkę o jej powinnościach i pełnionych rolach społecznych, dotknięta słowami syna Gertruda uderza go w twarz. Mężczyzna przechodzi jednak do skuteczniejszego ataku fizycznego, rzucając matkę na podłogę tuż obok ogromnych lustrzanych drzwi szafy. Przyciskając twarz Gertrudy do zwierciadlanej powierzchni, zniekształca spojrzenie matki, jednocześnie próbując przekonać ją, by zajrzała do swojego ciemnego wnętrza. Almereyda portretuje Gertrudę w czarnym, eleganckim szlafroku, a jego kolor może dodatkowo podkreślać zepsucie moralne kobiety.

Próba zmuszenia Gertrudy do przyjrzenia się sobie zostaje przerwana przez wołanie o pomoc oraz odgłos z szafy, na który Hamlet reaguje wyjęciem pistoletu i oddaniem strzału prosto w szybę lustra. Po chwili zza uszkodzonych drzwi wyłania się Poloniusz, zakrywający jedną ręką krwawiące oko, po czym pada martwy na podłogę. Podsłuchujący szpieg paradoksalnie zostaje uśmiercony strzałem prosto w oko. Roztrzaskana przez kulę pistoletu płaszczyzna lustra symbolizuje zdeformowane odbicie rzeczywistości elsynorskiej. Przerażona Gertruda jest całkowicie roztrzęsiona przytłaczającymi ją doświadczeniami wizualnymi i audialnymi. Jej beztroskie życie, wypełnione przyjemnościami zmysłowymi, zostaje nagle zachwiane przez szok percepcyjny, jaki powoduje u niej Hamlet. Gertruda podejmuje nawet próbę wykonania rozmowy telefonicznej, lecz syn powstrzymuje ją przed tym, zmuszając, by go wysłuchała. 
Pytanie adresowane do matki: „Czy wy macie oczy?” (3.4.879) dotyczy niemoralnych czynów, jakich dopuściła się po śmierci męża. Kamera pokazuje zbliżenie twarzy Gertrudy, w szczególności jej zaciśnięte powieki i zasłonięte rękami uszy. Hamlet w furii wciąga ją na łóżko z wcześniej porozrzucaną przez niego pościelą i zaczyna owijać matkę prześcieradłem. Jego brutalne zachowanie przerywa przybycie ducha ojca, który ze spokojem przypatruje się sytuacji. Upomina syna, by przemówił do rozdartej wewnętrznie matki. W obecności zjawy syn zachęca matkę do spowiedzi, a tym samym do zmiany punktu widzenia. Filmowe reprezentacje transformacyjnych doświadczeń wzrokowych i słuchowych są w tej scenie skoncentrowane głównie na Gertrudzie. Potwierdzeniem tego jest jej wyznanie: „Hamlecie, ty rozciąłeś moje serce / Na dwoje" (3.4.990-991).

Almereyda, inaczej niż Zeffirelli i Branagh, przemienia zakończenie sceny w rozmowę telefoniczną między matką i synem. Hamlet, który wynosi ze sobą ciało Poloniusza, dzwoni do zapłakanej Gertrudy z hotelowego automatu. Ich pożegnanie, podobnie jak pożegnanie z Ofelią, odbywa się za pośrednictwem urządzenia elektronicznego. Charakter tej rozmowy jest całkowicie audialny, a słuchawka telefonu, niczym przedłużenie ucha, stwarza wrażenie realnej bliskości głosu. Poprzez wykorzystanie podobnych urządzeń, w tym przede wszystkim wszędobylskich „oczu obiektywów”, w wielu scenach reżyser obnaża symulowane urealnienie percepcyjnej (słuchowej i wizualnej) obecności innej osoby.

\section{Aberracyjne, filmowe zachowania Ofelii}

W tragedii Hamlet widoczne staje się skontrastowanie kobiecego obłędu Ofelii z męskim szaleństwem Hamleta. Na ten temat pisała obszernie Elaine Showalter w artykule „Przedstawiając Ofelię: kobiety, szaleństwo i zadania krytyki feministycznej” (2000). Autorka wskazuje na wielość kulturowych reprezentacji tej kobiecej postaci dramatu, ze szczególnym uwzględnieniem wpływu ideologii danych czasów na owe przedstawienia. Showalter pokazuje ewolucję w ukazywaniu szaleństwa Ofelii: od siedemnastowiecznych odczytań uznających dziewczynę za erotomankę, poprzez dziewiętnastowieczne utożsamianie obłędu z kobiecą histerią, po interpretacje stanu obłąkania jako schizofrenii w XX wieku. Istotnym elementem rozważań Showalter jest wspomniane już rozróżnienie odnoszące się do cielesnego charakteru obłędu Ofelii i mentalnego aspektu szaleństwa Hamleta. 0 ile „Hamlet jest prototypem bohatera melancholicznego” i jego przypadłość na ogół jest „kojarzona z geniuszem intelektu i wyobraźnią", o tyle należy stwierdzić za Showalter, że „[ź]ródła kobiecej melancholii widziano w kobiecej biologii i kobiecych uczuciach" (2000: 194). Takie podejście ma istotne przełożenie na wyobrażanie aberracyjnych zachowań 
tej Szekspirowskiej postaci, obejmujących zachowania angażujące postrzeganie, a więc filmowe obrazowanie pomieszania zmysłów.

Interpretacja szaleństwa Ofelii według Showalter znajduje swoje odzwierciedlenie $w$ filmowych wyobrażeniach odmiennego stanu percepcyjnego bohaterki. Każdy z reżyserów adaptacji, ze względu na różniące się realia świata przedstawionego, nieco inaczej odczytuje kobiecy stan obłąkania. Warto po kolei przyjrzeć się teoriom wyjaśniającym obłęd Ofelii w zależności od epoki, w której umieszczono akcję filmu. Średniowiecze upatrywało w szaleństwie kontaktu z nadprzyrodzonymi mocami; obłęd mógł mieć zatem charakter zarówno profetyczny, jak i diaboliczny. Był wyrazem etosu średniowiecznego, znanego pod nazwą „psychemachii”, oznaczającego walkę pomiędzy duchem świętym a diabłem o władzę nad jednostką (Porter, 2003: 30). Uważano, że dusza jednocześnie walczyła z cielesnością, co w odniesieniu do kobiet nabierało szczególnego znaczenia - mogły zostać posądzone o uprawianie czarów i opętanie przez diabła. Jednak średniowieczna Ofelia z filmu Zeffirellego wydaje się łączyć zarówno prorocze, jak i profanacyjne tendencje obłędu. Obie one napawały lękiem mieszkańców Elsynoru, świadomych własnych występków i możliwości ich artykulacji przez nadprzyrodzoną moc słów Ofelii. Dopiero szaleństwo wyzwala w bohaterce nieograniczone możliwości artykulacyjne.

Warto zauważyć, że głosowość ludzka jest ściśle powiązana z percepcją słuchową. Wsłuchiwanie się w głosy i dźwięki płynące z zewnątrz kształtuje sposób własnego wypowiadania się, czyli przysłowiowy „własny głos”. Szczególnie istotny $\mathrm{w}$ rozwoju jednostki jest pierwszy słyszany głos, czyli głos matki, zaś pierwotną figurą kobiecej głosowości jest matka. Kaja Silverman twierdzi, że matczyny głos to „pierwszy głos miłości”, będący „potężną kulturową fantazją" (cyt. za Dunn i Jones, 1994: 11). Fantazja o ucieleśnionej obecności matki, śpiewającej dziecku swym kojącym głosem, odbija się echem w zachodniej literaturze i muzyce (Dunn i Jones, 1994: 11-12). Natomiast Cixous przyrównuje głos do muzyki, pisząc, że "[w]ewnątrz każdej kobiety pierwszą i niewysłowioną miłością jest śpiew" (cyt. za Dunn i Jones, 1994: 12). 0 wpływie głosu matki na Ofelię nie można dowiedzieć się z tekstu sztuki, nie ma też żadnego filmowego odniesienia. Można jedynie przypuszczać, że ów głos został całkowicie „zagłuszony” przez obecne w życiu dziewczyny głosy męskie, a więc ojca, brata i Hamleta. Przypuszczalnie głos Gertrudy mógłby stanowić podobny do matczynego, kobiecy głos, nadający się do naśladowania, zwłaszcza że Ofelia wydaje się niejednokrotnie przysłuchiwać i przypatrywać królowej ${ }^{3}$.

\footnotetext{
${ }^{3}$ Nieobecny w dramacie wątek dzieciństwa Ofelii i relacji rodzinnych rozwinęła wiktoriańska pisarka Mary Cowden Clarke. W pracy The Girlhood of Shakespeare's Heroines (1851), poświęconej wybranym bohaterkom Szekspirowskim, „dopisywała” historie, stylizowane na sentymentalne opowieści o ich dzieciństwie.
} 
Również wygląd Ofelii może wywoływać przerażenie u świadków jej wizualnej przemiany. Jak zauważa Rutter w artykule „Snatched Bodies: Ophelia in the Grave”, w pierwszym ujęciu w scenie szaleństwa „Ofelia wygląda, jakby wydrapywała się z grobowca. Najpierw wyłaniają się jej palce, wyginające się na krawędzi mokrego kamienia, potem jej głowa i oczy, na tym samym poziomie co kamień" (1998: 306). Bohaterka zaczyna przechadzać się po murach zamku. Jej obsceniczne zachowanie - łączące słowa i gesty - w stosunku do wartownika zapowiada podszyty niespełnieniem i pobudzeniem seksualnym charakter obłędu. Na przekór kilkakrotnie powtórzonemu przez Hamleta zaleceniu, by poszła do klasztoru, bohaterka ujawnia najgłębiej skrywane seksualne pragnienia.

Szczególnie zatrwożoną (i mającą okazję podejrzeć Ofelię przez okno) postacią okazuje się Gertruda. Odmieniona przywoływanymi przez Hamleta obrazami z przeszłości obawia się nie tylko widoku obłąkanej dziewczyny, ale przede wszystkim tego, co może od niej usłyszeć. Zeffirelli nie korzysta jednak z Szekspirowskiego wersu: „Nie chcę z nią mówić” (4.5.249), przeznaczonego dla królowej. Gertruda raczej zdaje się wiedzieć, że nie uniknie spotkania z kolejnym „głosem sumienia”. „Powstała z martwych” Ofelia wbiega do zamku i śmiało woła: „Gdzie piękna najjaśniejsza pani Danii?” (4.5.276). W odpowiedzi na zuchwałe zawołanie na schodach zamkowych pojawia się królowa, której nadrzędną pozycję podkreśla takie ujęcie kamery, które pokazuje ją ponad małą, podrzędną Ofelią. Wspinając się po schodach w stronę przerażonej królowej, Ofelia wyśpiewuje piosenkę o zmarłym mężczyźnie. Królowa próbuje zbiec po schodach, lecz dziewczyna impertynencko staje jej na drodze, co tylko wzmaga obawy Gertrudy. Przez chwilę kobiety mają okazję obserwować swoje zachowanie, przy czym to królewski wzrok Gertrudy wyraża strach i zakłopotanie, zaś obłędne spojrzenie dotąd nieśmiałej dziewczyny komunikuje nieobliczalność i zawieszenie pomiędzy światem realnym a urojonym. Zeffirelli stara się maksymalnie skoncentrować na żałosnym stanie Ofelii, opuszczając wersy Klaudiusza i Gertrudy, którzy praktycznie tylko obserwują (Cieślak, 2001: 43). Zdaniem Cieślak:

W tej scenie Zeffirelli odrzuca większość tekstu sztuki i koncentruje się na wyeksponowaniu wewnętrznego stanu Ofelii poprzez niewerbalne środki. Kamerę absorbuje portretowanie: jej wyrazu twarzy i zachowań - półśpiewu słabym i załamującym się głosem, rozkojarzonego rozglądania się, płaczu na przemian ze śmiechem i balansowania na granicy emocjonalnego wybuchu (43).

Kolejnym obiektem zainteresowania Ofelii zostaje przechadzający się po zamku Klaudiusz, w którego kierunku pośpiesznie udaje się Gertruda. Król zwraca na siebie uwagę pytaniem o samopoczucie dziewczyny. Ofelia przerywa symulowane czynności i wyimaginowane rozmowy, by podejść blisko króla i wskazując na niego palcem, wypowiedzieć znamienne słowa: „Powia- 
dają, że sowa była córką piekarza. Boże, Boże, wiemy, czym jesteśmy, lecz nie wiemy, czym możemy zostać" (4.5.296-297). Zeffirelli wybiera z tekstu dramatu te kwestie, które nie tylko w osobisty, ale i polityczny sposób mogą dotknąć słuchaczy. W stosunku do Klaudiusza niebezpieczne może być też jej ambiwalentne stwierdzenie, że Laertes dowie się o wszystkim. W związku z tym Klaudiusz nakazuje pilne strzeżenie bohaterki.

Kamera zwraca też uwagę na przerażoną Gertrudę, która kurczowo ściska zawieszony na piersiach krzyż. W opinii Lawsona obłąkana bohaterka przejściowo przejmuje władzę nad parą królewską (1997: 241). Profetyczne słowa Ofelii, w połączeniu z jej przejmującym widokiem, poruszają zmysły zarówno świadomej swych występków pary królewskiej, jak i zebranych dworzan - świadków wynaturzonych zachowań bohaterki. Reżyser upublicznia scenę szaleństwa, sprawiając, że w obecności większej ilości gapiów i słuchaczy dodatkowo nabiera ono groźnej mocy rozprzestrzeniania się plotek i podejrzeń.

Zeffirelli nie tylko nie marginalizuje pomieszania zmysłów bohaterki, ale wręcz je eksponuje w ujęciach całej postaci albo tylko jej fragmentów, jak na przykład w omawianej powyżej scenie. Technikę tę komentuje Lawson:

Zanim opuści zamek, Ofelia jest ukazana powyżej talii, mając ponad sobą spiralne schody i krużganki, niczym „więzienia Piranesiego” albo architektoniczna „symetria skrzydeł”. Umieszczona na tle gigantycznej próżni wnętrza zamkowego wydaje się mała i krucha (1997: 242).

Reżyser świetnie wykorzystuje przestrzeń do tego, by oddac wątły stan ducha i ciała Ofelii. Zarówno przytłaczające niewielką postać dziewczyny wnętrze zamku, jak i nieprzyjazne dla niej mury budowli, nie pozostawiaja wątpliwości, że Ofelia na ich tle:

Staje się żywą reprezentacją rozpaczy, kiedy ryzykuje wyjście na zewnątrz [zamku] i znajduje drogę wzdłuż mokrej, kamiennej drogi za pomocą nagich stóp. Gdy widoczne staje się, że dopada ją rozpacz, przylega do zimnej, kamiennej, zewnętrznej ściany zamku, wybuchając niekontrolowanym płaczem (242).

Próba ucieczki z zamku, pełnego nieprawości, zakłamania oraz zakazów i nakazów, świadczy o usiłowaniu wydostania się z miejsca, w którym samowolne praktyki szpiegowskie doprowadziły bohaterkę do emocjonalnego załamania.

W adaptacji Zeffirellego Ofelia bez skrępowania porusza się po zamku elsynorskim i w takim też stanie spotyka ją przybyły na dwór, żądny zemsty za śmierć ojca Laertes. Rutter podaje, że brat „zastaje ją w sytuacji, gdy [Ofelia] siedzi ze skrzyżowanymi nogami na tronie Gertrudy, oddzielając fragmenty kości i traw, które dla niej są jej kwiatami" (1998: 307). Jej zdaniem Laertes z przerażeniem natrafia na odmienioną fizycznie i psychicznie siostrę: 
To [tylko] bezmyślne dziecko, które powierza „pamiątki” dłoniom nieskorym do ich przyjęcia; [dziecko], które charakteryzuje obłąkańczy chód, które wkłada sobie za ucho „rutę” niczym różę, i które kokieteryjnie gładzi swoje włosy. Lecz to właśnie dziecko wysunęło roszczenia do tronu, dopominało się rozmowy z Gertrudą i poprzez swoją osobę uczyniło dosłownymi metafory dotyczące zatrucia szerzącego się wokół tego tronu od samego początku filmu (1998: 307).

Bez lęku o to, czyj wzrok może napotkać, bez strachu o to, jak odebrane będą jej słowa, Ofelia Zeffirellego oswobadza swoje zmysły z dotychczasowych ograniczeń. Opuszczając salę tronową, po raz ostatni ogrania wzrokiem: oniemiałego Laertesa, przytłoczoną Gertrudę oraz niespokojnego Klaudiusza. Z jednej strony zmysły Ofelii zdają się nie rozpoznawać w postaciach ich dotychczasowych tożsamości, z drugiej zaś - jej celne gesty i słowa zdają się wizualnie i słuchowo, w przemyślany sposób, przemawiać do każdej postaci. Filmowa konstrukcja odmiennego stanu percepcyjnego Ofelii wskazuje na dużą aktywność wyobraźni bohaterki, na którą składają się wcześniejsze doświadczenia wizualne i kulturowe obrazy, czyli męskie wyobrażenia na temat kobiecości, tak liczne i zapewne uporczywie kłębiące się w jej głowie. Manipulowana dotąd także poprzez oddziaływanie słowami na jej „wrażliwy" organ słuchu (liczne pouczenia ojcowsko-braterskie, odtrącenie przez Hamleta), teraz to ona, wręcz nieznośnie, dominuje swym głosem.

Kolejna sekwencja poświęcona tej postaci przedstawia jej żywiołowy i pełen wolności bieg dookoła zamku, zbieranie przez nią kwiatów nad strumieniem oraz ostatnie spojrzenie w kierunku swobodnie płynącej wody. Ofelia pozostaje milcząca, a w tle słychać głos narratora-Gertrudy. Zeffirelli stosuje w tej scenie technikę niewidocznego komentatora, którym okazuje się królowa, opisująca ostatnie chwile z życia wyzwolonej Ofelii. Szczególnie dobitnie reżyser oddaje wyraz twarzy bohaterki: z nienaturalnie szeroko otwartymi oczami, który przechodzi w postać Gertrudy zdającej poetycką relację z utonięcia dziewczyny.

Rozwiązanie zastosowane przez Zeffirellego to przejście od powiększonego ujęcia, wydobywającego szczegóły twarzy Ofelii, do postaci Gertrudy, ubranej w czarną suknię i ukazanej na ekranie tylko fragmentarycznie. Powtórnie, tuż po zakończeniu opowieści królowej, kamera powraca do Ofelii. Tym razem widoczna staje się niewielka postać martwej bohaterki, pływającej („uwięzionej”) w zatoce morskiej, obok zamku. Zeffirelli unika pokazania jej z bliska na rzecz sfilmowania tej postaci z dystansu. Nieżywą, śnieżnobiałą Ofelię postanawia pokazać z bliska dopiero w scenie jej pogrzebu. Wówczas kamera kilkakrotnie skupia się na śpiącej postaci: niczego już niewidzącej i niczego niesłyszącej, bowiem jej uszy i oczy zostały na zawsze zamknięte.

Dziewiętnastowieczne realia, w które przenosi nas najdłuższa w historii kina wersja Hamleta w reżyserii Branagha, ukazują penitencjarny system traktowania jednostek stygmatyzowanych szaleństwem, w tym kobiet 
naznaczonych histerią (z gr. hystéra - 'macica') ${ }^{4}$. Ubezwłasnowolniona kaftanem bezpieczeństwa, przetrzymywana w pokoju bez okien i zmuszana do hydroterapii, Ofelia Branagha wpisuje się w dziewiętnastowieczne postrzeganie obłędu zaproponowane przez Freuda. Branagh także „stygmatyzuje” swoją bohaterkę i lokuje ją w niewielkim pomieszczeniu (jednym z pokojów za lustrzanymi drzwiami pałacu), wyłożonym miękkim obiciem, w którym szamocząca się bohaterka odbija się od ściany do ściany, wydając przy tym osobliwe dźwięki. Niewielka przestrzeń ma za zadanie odciąć Ofelię od nowych bodźców słuchowych i wzrokowych. Dotychczasowy natłok doświadczeń percepcyjnych doprowadza ją bowiem do stanu pomieszania zmysłów. Zmagania z przestrzenią i odmiennym stanem świadomości Ofelii obserwuje między innymi Gertruda, spoglądająca w dół przez przeznaczony do tego celu otwór w suficie. Zamknięta w celi Ofelia przypomina miotające się w klatce zwierzę. Reżyser tym wstępnym ujęciem ustanawia relację: obserwator-obserwowany i po raz kolejny wykorzystuje w swojej adaptacji kontrolujące właściwości zmysłu wzroku. Branagh nie upublicznia sceny szaleństwa, dlatego nabiera ona charakteru przedstawienia wizualno-audialnego dla bardzo ograniczonego grona odbiorców (Gertruda, Klaudiusz, Horacjo, opiekunka).

Po namowach Horacja królowa postanawia spotkać się z Ofelią w lustrzanej sali pałacowej. Zastaje tam dziewczynę w kaftanie bezpieczeństwa, ułożoną horyzontalnie, twarzą w stronę czarno-białej, przypominającej szachownicę, podłogi pałacowej. Królowa zostaje uprzedzona o pozornie bezładnych wypowiedziach Ofelii oraz o potencjale interpretacyjnym „tkwiącym” w uchu słuchacza. Nie przez przypadek reżyser ulokowuje scenę szaleństwa w tym samym pomieszczeniu pałacowym, w którym jej zmysły zostały wystawione na próbę podczas spotkania z Hamletem. Ponadto Branagh bardzo drastycznie, pod względem wzrokowym i słuchowym, portretuje zmiany, jakie zaszły w bohaterce. Przejście od wizerunku pięknej damy, nienagannie posługującej się językiem, do wizerunku spętanej histeryczki, wyśpiewującej folklorystyczne piosenki, sprawia, że „oczy i uszy” stykające się z odmienioną Ofelią z trudem dowierzają temu, co widzą i słyszą.

Ograniczenie ruchów bohaterki nie powoduje ani osłabienia działania jej zmysłów, ani oddziaływania nimi na otoczenie. Ofelia kieruje pytanie o królową Danii w stronę podłogi, a obecna już w sali pałacowej i przyglądająca się jej z pozycji stojącej Gertruda reaguje pochyleniem się w stronę spętanej kobiety. Królowa uwalnia ją z uścisku kaftana, podczas gdy Ofelia wykrzykuje, by ją wysłuchano i zaczyna wyśpiewywać pierwszy fragment ballady:

\footnotetext{
${ }^{4}$ W artykule „Histeria. Feminizm. Terapia” (2004) Urszula Śmietana sięga do genealogii histerii, która swe początki „zawdzięcza” Platońskiej teorii wędrującej macicy, przez Freudowską koncepcję histerii jako stłumionej kobiecej energii seksualnej, niemogącej znaleźć „ujścia”, aż po feministyczne interpretacje tej „choroby” jako „kobiecego protojęzyka” (Showalter), jako her-story, wyrażającej niecenzuralne kobiece „ja”.
} 
Droga Pani, on nie żyje,

Zmarł i złożon w grób

Głowę ma na świeżej darni,

Głaz u jego stóp (4.5.284-287).

Wejście Klaudiusza powoduje, że Ofelia powstaje i zamiast śpiewu adresuje do niego z pozoru bezsensowne wypowiedzi. Na przypuszczenie Klaudiusza, że wspomina o ojcu, bohaterka reaguje histerycznym krzykiem i oddaleniem się w głąb sali. Dotąd uciszana, w odmiennym „stanie percepcyjnym" (czy też w innym stanie świadomości i cielesności) sama ma odwagę uciszyć zebranych. Wybuch obłąkańczych dźwięków, które przeszywają uszy Klaudiusza i Gertrudy, sprawia, że nikt nie stara się przerwać następującej po tym eksplozji szaleństwa. Kamera pracuje raczej z oddali, nie skupiając się na detalach twarzy pary królewskiej.

Ofelia niezwykle intensywnie oddziałuje tonem i modulacją swojego głosu. Nienaturalne krzyki, posługiwanie się wyśpiewywanymi balladami i zmienność rytmu wyróżniają obłąkańczą mowę bohaterki. Warto wspomnieć, że wykorzystanie zmysłu słuchu oraz wytwarzanie głosu i artykulacja zależą nie tylko od biologicznych predyspozycji danej jednostki, lecz w dużej mierze od praktyk społecznych w kulturze Zachodu, preferujących silny i władczy głos męski oraz delikatny i spokojny kobiecy. Jak twierdzi Nelly Furman, ponieważ zarówno język, jak i społeczeństwo, są ustrukturyzowane za pomocą kodów różnicy seksualnej, również ciało wraz z głosem w nieunikniony sposób podlegają podziałom według płci społeczno-kulturowej. Nie chodzi jednak o to, że głosy posiadają wrodzoną właściwość męską lub żeńską (cyt. za Dunn i Jones, 1994: 2). Wokalny podział według płci kulturowej wydaje się raczej produktem złożonych wzajemnych oddziaływań pomiędzy różnicami anatomicznymi, procesem socjalizacji w kierunku wypełniania ról społecznych oraz „kontrastujących możliwości ekspresji, które są dostępne mężczyznom i kobietom w określonym społeczeństwie" (cyt. za Dunn i Jones, 1994: 2-3). Innymi słowy, akustyczne i ekspresyjne właściwości głosu są w takim samym stopniu kształtowane przez indywidualny rozwój kulturowy, jak i przez jednostkowe użycie języka (Dunn i Jones, 1994: 3).

Kulturowemu, a więc normatywnemu użyciu języka wydaje się nie podlegać zwariowana Ofelia. Łamiąc, tak mocno akcentowane w adaptacji Branagha, reguły i konwenanse dworskie, przekracza ona granice społecznie akceptowanego, genderowego posługiwania się językiem. Nie tylko Gertruda spotyka się z uciszającym ją wrzaskiem Ofelii, ale także Klaudiusz. Gdy nareszcie oswobodzone ręce bohaterki mogą nieskrępowanie się poruszać, zaczyna nimi wymachiwać w rytm wyśpiewywanej przez siebie ballady o odtrąconej kochance. Do tego, by zainscenizować wykorzystanie seksualne i porzucenie przez mężczyznę, Ofelia wybiera króla. Mimo że Klaudiusz próbuje 
jej to uniemożliwić, bohaterka nie rezygnuje. W arogancki sposób zbliża się do niego i niemalże całym ciałem przylega do mężczyzny. Ostatnie wersy ballady wyśpiewuje, patrząc mu prosto w oczy, zaś agresywnym gestem pchnięcia miednicą w narządy płciowe Klaudiusza podkreśla swobodę, z jaką mężczyźni podchodzą do relacji seksualnych z kobietami. Nie zwracając uwagi na wizualne i werbalne znieważenie króla, Ofelia upada na podłogę. Leżąc na plecach, symuluje akt seksualny, który ma być odtworzeniem jej erotycznych wspomnień związanych z Hamletem. Branagh wplata w ten fragment dwie retrospekcje - obsesyjne, najbardziej intymne obrazy, wypełniające pamięć i wyobraźnię bohaterki. Ofelia wydaje się owładnięta owymi wspomnieniami i bardzo intensywnie pobudzona w analizowanej scenie. Na koniec konwulsyjnie przewraca się na brzuch, by po chwili kamera pokazała rozemocjonowaną i zapłakaną twarz w przybliżeniu.

Choć scena szaleństwa zmontowana jest głównie z ujęć z dystansu lub z półzbliżeń, Branagh decyduje się na pokazanie z bliska zniekształconego przez obłęd oblicza Ofelii. Chwilowe wyciszenie bohaterki sygnalizuje wbity w posadzkę wzrok oraz nieco spokojniejszy ton głosu. Finalizuje ona swoje szalone przemyślenia poruszającym Klaudiusza stwierdzeniem, że jej brat zostanie o wszystkim poinformowany. Zdenerwowany król usiłuje skrępować kaftanem ręce Ofelii, lecz ta wyrywa się z jego uścisku i korzystając z ostatnich chwil wolności, umyka z sali pałacowej. Zgodnie z nakazem Klaudiusza natychmiast podążają za nią Horacjo i opiekunka. Pierwsza sekwencja poświęcona obłędowi w adaptacji Branagha akcentuje spotęgowane działanie zdolności percepcyjnych Ofelii i niekontrolowane możliwości wpływania przez nią na wzrok i słuch innych postaci.

Następna sekwencja, oddająca percepcyjne stany aberracyjne Ofelii, rozgrywa się w obecności przybyłego na dwór elsynorski Laertesa. Zanim Ofelia wbiegnie do lustrzanej sali pałacowej, Laertes przeprowadza rozmowę z Klaudiuszem i Gertrudą. Jedno z ujęć pokazuje, jak dziewczyna desperacko próbuje uciec przed podążającą za nią, niczym cień, opiekunką. Wydaje się, że dla Ofelii Elsynor dosłownie stał się więzieniem, a ograniczenie do minimum jakichkolwiek zmysłowych doświadczeń jeszcze bardziej pogrąża bohaterkę w stanie ciągłego odtwarzania przeszłych doświadczeń w tym zakresie.

W takiej kondycji zastaje ją brat, którego Ofelia ignoruje. Bohaterka przysiada bokiem przy jednym ze zwierciadeł w komnacie tronowej, tak że część jej twarzy odbija się w lustrze. Wcale nie spogląda na swoje odbicie, praktycznie je lekceważąc. Kamera koncentruje się na zachowaniu Ofelii - dziwacznych gestach wykonywanych palcami, przerywanym śmiechu i zaabsorbowaniu wewnętrznymi wizjami i głosami, które wydaje się widzieć i słyszeć. Siedzący na wprost Ofelii oszołomiony brat komentuje ten niecodzienny obraz. W pewnym momencie chora nawiązuje kontakt $\mathrm{z}$ otoczeniem - zaczyna wyśpiewywać kolejną balladę, aluzyjnie komentuje niemoralne wydarzenia 
na dworze elsynorskim, rozdaje wyimaginowane kwiaty, wskazując spojrzeniem po kolei na Laertesa, Gertrudę i Klaudiusza. Szczególnie poruszająca jest ostatnia piosenka, opłakująca zmarłego mężczyznę, wyśpiewana przez Ofelię ostatkiem sił. Po chwili kamera pokazuje, jak bohaterka wstaje i sama wchodzi do swojej pałacowej „celi”, jakby w geście poddania się zabiegom, które ją czekają. Filmowe reprezentacje zmysłów Ofelii wskazują na wyciszenie tej postaci, ale także na przytłoczenie bagażem emocjonalnym, na który składają się wycieńczające doświadczenie wzrokowe i słuchowe.

Branagh kontynuuje wątek pacyfikacji histerycznej Ofelii przez ukazanie praktyki hydroterapii, jakiej poddawana jest bohaterka. W ostatnim ujęciu „torturowanej” Ofelii widać, jak trzęsąca się z zimna i ociekająca wodą, wyjmuje z ust wykradziony klucz, dzięki któremu ucieczka z elsynorskiego więzienia stanie się możliwa. Według Hanny Scolnicov, autorki artykułu „Intertextuality and Realism in Three Versions of Hamlet: The Willow Speech and the Aesthetics of Cinema", w wersji Branagha:

Szaleństwo Ofelii jest ukazane jako funkcja jej uwięzienia w granicach zamku, gdzie panuje zepsuty patriarchalny system. Męska opresja jest zakodowana w przymusowych zimnych prysznicach oraz kaftanie bezpieczeństwa, który składa się na część narzuconej jej, pełnej przemocy „kuracji” (2000: 235).

Z kolei strukturalna kompozycja dramatu „narzuca”, trzymającemu się ściśle tekstu, Branaghowi konieczność przekazania wiadomości o śmierci Ofelii przez Gertrudę. Reżyser rezygnuje ze zilustrowania przekazu królowej filmowym obrazem ostatnich chwil z życia obłąkanej Ofelii. Scolnicov zauważa, że jest to teatralny sposób potraktowania tego poetyckiego fragmentu (234). Badaczka komentuje sposób zrelacjonowania sceny utonięcia przez Gertrudę Branagha i sugeruje, że jest to narracja „stwarzająca naturalne otoczenie, oddzielny świat, dla kobiet, poza opresyjnymi granicami Elsynoru" (235).

Jedynym filmowym zobrazowaniem utonięcia bohaterki jest sportretowanie całkowicie zanurzonego w wodzie fragmentu ciała Ofelii. Reżyser stosuje przejście od półzbliżenia Gertrudy do zbliżenia Ofelii. Branagh w ujęciu z góry, jak gdyby umieszczając kamerę tuż nad powierzchnią wody, eksponuje twarz, otwarte oczy i rozpostarte ramiona bohaterki. Delikatnie falująca woda zniekształca rysy postaci, która wydaje się przynależeć do podwodnego świata. Obraz Ofelii „ukrytej” za lustrzaną powierzchnią wody, to również nawiązanie do głównego motywu filmu - zwierciadlanych powierzchni. Ofelia powraca jeszcze raz na ekran w scenie pogrzebu. Choć jej trumna początkowo pozostaje zamknięta, Branagh decyduje się odkryć jej zawartość (Laertes zrywa wieko trumny). Pożegnalne ujęcia tylko na chwilę koncentrują się na przytrzymywanej przez brata Ofelii. W scenie pogrzebu bohaterka 
pozostaje prawie niewidoczna i mimo wcześniejszych dodatkowych ujęć tej postaci, które wykraczają poza tekst dramatu, ostatecznie zanika nie tylko pod względem narracyjnym, ale także wizualnym.

Ostatnią postać oszalałej Ofelii portretuje Almereyda. Jego dekadencka Ofelia jawi się jako postać w stanie depresji, jeśli przyjąć kategorie współczesnego dyskursu interpretującego szaleństwo. Reżyser wykreował wizerunek Ofelii przygnębionej, o kamiennym wyrazie twarzy, która pomimo posiadania własnego mieszkania, własnej pasji, jaką jest fotografowanie, nie posiada swobody postrzegania bez aparatu fotograficznego. Podobnie jak jej filmowe poprzedniczki, pragnie ona w stanie obłędu choć częściowo wyzwolić swój potencjał wizualny i werbalny. Ofelia Almereydy jest postacią separującą się od otoczenia, która

sama chroni się przed rzeczywistością, chowa się w ciemni (także z Hamletem), tam gdzie ukrywa swój świat z fotografii. Jednak izolacja ta jest krucha, rzeczywistość istniejąca poza ciemnią i kadrami zdjęć zaczyna ingerować w życie bohaterki, w brutalny sposób zmusza ją do zachowania i postępowania, od jakiego stroniła (Kołos, 2007: 149).

Trzymanie się w odosobnieniu wpływa także na ograniczenia komunikacyjne, a dokładniej - na fragmentaryczne bezpośrednie rozmowy z innymi postaciami. Bohaterka adaptacji Almereydy to postać wyjątkowo zamknięta pod względem werbalnym, być może z powodu „zagłuszania” jej prawdziwego głosu przez otaczający ją zewsząd męski wokal. Warto zauważyć, że na indywidualny rozwój ma wpływ to, co Furman określa jako „wielość mitów, które modulują odbiór słuchowy głosu”, w tym mity „o głosowej płci społeczno-kulturowej" (cyt. za Dunn i Jones, 1994: 3). Mogą one obejmować stereotypy dotyczące różnicy seksualnej: kobiece głosy są uważane za wysokie i przenikliwe lub szepczące, podczas gdy męskie - za niskie i spokojne lub szorstkie. Przypisywane głosom społeczne znaczenia umacniane są przez różnice oraz atrybuty władzy, związane z właściwościami głosowymi każdej z płci (Dunn i Jones, 1993: 3). Sposób wykorzystania głosu staje się narzędziem pozwalającym na usytuowanie jednostki w strukturze społecznej. Odnalezienie „własnego głosu” w społeczeństwie wymaga zaakceptowania kodów głosowości, czyniąc z owej „własności prywatnej” zbiorowy instrument do wydawania uporządkowanych dźwięków. „Zagłuszanie” słabszego głosu przez silniejszy na przykładzie Ofelii Almereydy pokazuje, jak głęboko głosowość zakorzeniona jest w relacjach władzy. Dopiero stan obłąkania wyzwala w bohaterce głęboko ukryte pokłady dotychczas niewyrażalnego bólu i osamotnienia.

Scena szaleństwa zostaje usytuowana przez reżysera w miejscu publicznym, w Muzeum Guggenheima. Cechą charakterystyczną tego wnętrza jest spiralna architektura, sprawiająca wrażenie, że osoba wspinająca się z jed- 
nego poziomu na drugi prawdopodobnie dostaje zawrotów głowy. Na takich filmowych doznaniach Ofelii skupia się kamera w scenie wybuchu obłędu. Almereyda akcentuje stan dezorientacji bohaterki, kiedy zagubiona, kręcąc się wzdłuż muzealnych balustrad, ewidentnie próbuje kogoś odnaleźć wśród zaproszonych gości. Jak się okazuje, stara się odszukać królową, która pozostaje zaabsorbowana rozmową. Dziewczyna impertynencko przepycha się w kierunku Gertrudy, nie zważając na towarzyszących jej rozmówców. Pod presją odmiennego „percepcyjnego zachowania” Ofelii, w końcu odchodzi z intruzką nieco na bok, rozglądając się przy tym dookoła w obawie przed wywołaniem skandalu przez niestosowne zachowanie dziewczyny.

Reżyser pokazuje obie postacie w półzbliżeniach, oddając nie tylko zażenowanie Gertrudy, ale także załamanie Ofelii. Rozpaczająca bohaterka sensorycznie osacza Gertrudę. Kamera eksponuje widok, jak Ofelia chwyta się za głowę i zaczyna bezładnie mówić o zmarłym mężczyźnie. Gdy Gertruda lekceważy jej wypowiedzi, dziewczyna wydaje z siebie histeryczny krzyk, który ma zwrócić uwagę na jej słowa. Z pomocą żonie przybywa Klaudiusz, który próbując uspokoić Ofelię pytaniem o samopoczucie, wzmaga tylko jej frustrację. Bohaterka decyduje się na wyrażenie skumulowanych w niej emocji w zupełne nieoczekiwany dla Klaudiusza i Gertrudę oraz łamiący wszelkie konwenanse sposób. Zamiast tradycyjnej ballady, mającej naprowadzić słuchaczy na trop jej szaleństwa, z ust Ofelii daje się słyszeć przeraźliwy krzyk. Jest on skierowany w akustycznie przepastną przestrzeń muzeum i jednocześnie do wszystkich zdolnych ją usłyszeć zaproszonych gości. Reżyser najpierw stosuje oddalone ujęcie $\mathrm{z}$ dołu, które przedstawia kilka białych spiralnych poziomów budynku, a na jednym z nich tylko cztery stojące postaci. Choć z pozoru trudno je rozpoznać, wiadomo, że są to Ofelia, Gertruda, Klaudiusz i jego ochroniarz. Kiedy Ofelia zaczyna krzyczeć, kamera (tym razem ze średniego planu) pokazuje, jak Klaudiusz zatyka ręką usta oszalałej i odciąga ją od balustrady, natomiast skompromitowana Gertruda próbuje wymuszonym uśmiechem uspokoić świadków zdarzenia. Ponieważ Ofelia nie rezygnuje z aluzyjnych komentarzy i wygraża Klaudiuszowi, ochroniarz siłą usuwa z pola widzenia i słyszenia zakłócającą ciszę i wizualnie niepokojącą bohaterkę.

Kolejna sekwencja, która pokazuje szaloną Ofelię, nadal rozgrywa się w tym samym muzeum, lecz nieco na uboczu - na jednym z korytarzy budynku, „z dala od oczu i uszu” publiczności. Snująca się korytarzem Ofelia napotyka Klaudiusza, Gertrudę i Laertesa. Zamiast kwiatów, które rozdaje w dramacie bohaterka, w filmie Almereydy wręcza fotografie. Kamera oddaje stan niezrównoważenia Ofelii. Rejestruje jej chwiejny chód, szlochający głos, rozbiegane oczy i momenty rozrzucania fotografii. Laertes prowadzi i podtrzymuje słaniającą się z rozpaczy siostrę. Choć reżyser eksponuje głównie zachowanie Ofelii, można też dostrzec Klaudiusza i Gertrudę, którzy przypatrują się i przysłuchują całej scenie. Ostatnie ujęcie uwypukla wizualną 
i werbalną bierność Ofelii. Jej wzrok częściej błądzi, aniżeli jest celowo zwrócony na którąkolwiek z postaci. Podobnie można odebrać jej wypowiedzi, bo wydają się nie mieć określonego słuchacza. Wcześniejsza izolacja Ofelii osiąga punkt kulminacyjny w scenie szaleństwa, sprawiając, że zasklepia się ona w odtwarzaniu przeszłości, na którą składają się między innymi minione doświadczenia wzrokowe i słuchowe.

Skracająca tekst dramatu, filmowa strategia Almereydy przejawia się również w sposobie sportretowania martwej Ofelii. Wiadomość o jej utonięciu przynosi Klaudiuszowi, konspirującemu z Laertesem, zapłakana Gertruda. Reżyser pozbawia scenę wersów opisujących śmierć przez utonięcie w strumieniu, ponieważ $w$ tej adaptacji Ofelia tonie w fontannie, przy której w jednej z wcześniejszych scen oczekiwała na Hamleta. Ujęcie z lotu ptaka ukazuje dziewczęcą postać unoszącą się na wodzie fontanny. Przez chwilę można odnieść wrażenie, że postać żyje, jednak wyciągający ją z wody ochroniarz z trudem podnosi martwe, mokre ciało. Przez chwilę widać twarz Ofelii, lecz kamera zaraz przesłania ją postacią mężczyzny. Po Ofelii pozostają tylko listy, porozrzucane w fontannie. Po tak bardzo enigmatycznym obrazie zatopionej bohaterki Almereyda więcej jej nie pokazuje. W scenie pogrzebu trumna pozostaje zamknięta, przez co Ofelia staje się percepcyjnie niedostępna dla otoczenia.

Trzy analizowane w pracy wizerunki Ofelii ukazują ją jako postać posiadającą, w mniejszym bądź większym stopniu (podobnie jak w sztuce), możliwości nieskrępowanego i aktywnego korzystania ze zmysłu wzroku i słuchu. W Hamlecie Zeffirellego, Branagha i Almereydy rozbicie to staje się widoczne w postaci czynnego zaangażowania wzroku i słuchu męskich postaci dramatu oraz w narzuceniu męskiego punktu widzenia Ofelii. Jej kobieca perspektywa zostaje podporządkowana męskiemu systemowi reprezentacji, w szczególności zaś podlega oglądowi kobieca cielesność. Wiedza, którą Ofelia czerpie na swój temat, nie pochodzi z samoobserwacji, lecz jest wynikiem oceny kilku par oczu, w tym głównie ojca, brata i Hamleta. Można by pokusić się o stwierdzenie, że szaleństwo jest dla dziewczyny „przejrzeniem na oczy", które, mimo że tragiczne w skutkach, pozwala jej choć na moment ujrzeć siebie w innym świetle. Być może jest też wynikiem nałożenia na siebie wielu obrazów mentalnych dotyczących jej postaci jako cielesnego obiektu zakazów i nakazów postępowania. Zaburzona relacja z własnym ciałem wywołuje u Ofelii zniekształcone wyobrażenie o jej seksualności i tożsamości. Dopiero w stanie obłędu nadaje ona własnej percepcji wizualnej atrybuty sprawstwa, czyli zaangażowania w konstruowanie wiedzy na temat zastanej rzeczywistości. Obserwując otoczenie i przywołując minione obrazy w pamięci, dziewczyna samodzielnie nadaje znaczenie i interpretuje wydarzenia. Percepcja wzrokowa i słuchowa spotykają się na płaszczyźnie językowej, gdzie światopogląd ma szanse w końcu zostać wyartykułowany. 
Błądzenie wzrokiem i z pozoru nonsensowne wypowiedzi, w połączeniu $\mathrm{z}$ wyśpiewywaniem ballad ludowych, to wynik nałożenia na siebie wielu wyobrażeń o świecie oraz głosów brzmiących w głowie Ofelii.

\section{Zmysły a skutki sceny finałowej}

W Hamlecie Zeffirellego scena finałowa toczy się w sali tronowej zamku elsynorskiego. Strefę pojedynku wyznacza specjalnie przygotowana do tego celu drewniana arena, wokół której zgromadzeni są dworzanie. Para królewska obserwuje pojedynek z tronów. Zeffirelli kontynuuje w omawianej scenie strategię polegającą na zaabsorbowaniu uwagi widza wizerunkiem Gertrudy, zwłaszcza jej obecnością wizualną na ekranie. Choć struktura dramatu wskazuje na eksponowanie oddziaływań percepcyjnych pomiędzy Hamletem a Klaudiuszem, Zeffirelli zdaje się preferować relację między Gertrudą a jej synem.

Reżyser początkowo narzuca swobodną atmosferę $\mathrm{w}$ trakcie walki na miecze, ponieważ Hamlet kontynuuje swoje wcześniejsze błazeńskie zachowanie. Jest to niespotykane $w$ innych adaptacjach przedłużenie maskaradowego zachowania głównego bohatera. Jego frywolne gesty w trakcie pojedynku, prześmiewcze uwagi oraz mrugnięcia okiem w stronę matki nie zapowiadają mającej się rozegrać tragedii. Jej początkiem jest sięgnięcie przez Gertrudę po kielich z trującą perłą (wcześniej Klaudiusz jawnie i z „objaśnienieniami” wrzuca do wina truciznę) i spróbowanie przez nią toksycznego napoju. Klaudiusz próbuje powstrzymać żonę przed opróżnieniem kielicha, upominając ją, ale Gertruda stoi już przy Hamlecie i przechyla naczynie. Sprzeciwienie się mężowi to zarazem pierwszy i ostatni przejaw nonkonformistycznej postawy królowej. Nieświadoma zawartości kielicha, matka proponuje wino Hamletowi, lecz ten odmawia. Otarcie twarzy Hamleta i pocałunek w policzek sugerują zawarcie zgody między matką a synem po wcześniejszym burzliwym spotkaniu.

Gertruda Zeffirellego ma też okazję zorientować się, że król jest zdrajcą. Charakterystyczne są ujęcia królowej na tronie, całkowicie poddanej działaniu trucizny; królowej, która w końcu zwraca wzrok ku (wpatrującemu się w nią) Klaudiuszowi, a następnie spogląda na kielich. Operując kamerą w taki sposób, reżyser podkreśla moment, w którym do Gertrudy dociera prawda - moment jej metaforycznego przebudzenia. Przerażonym spojrzeniem Klaudiusz demaskuje podstęp, a oczy bohaterki potwierdzają jego odkrycie. Widać, że królowa jednak nie ma sił, by wydobyć z siebie głos i ostrzec syna. Jej zdolności artykulacyjne zostają ograniczone przez paraliżujące działanie trucizny. Dopiero po zakażeniu Hamleta zatrutym mieczem Gertruda ostatkiem sił werbalnie wskazuje na otrute wino jako przyczynę jej śmierci. Od strony wizualnej może się wydawać, że upada na podłogę pod wpływem 
widoku krwi, jednak jej słowa: „Nie, nie, napój, napój! - Drogi / Hamlecie” (5.2.692-693) wyjaśniają prawdziwą przyczynę. Ponadto Laertes ujawnia, że pomysłodawcą trujących zbrodni jest Klaudiusz. W akcie zemsty Hamlet zabija stryja przez ugodzenie go mieczem i wlanie mu do ust pozostałości toksycznego trunku.

Mimo że misja opowiedzenia jego historii spoczywa na Horacju, w scenie finałowej umierający Hamlet adresuje pożegnalne słowa nie tylko do niego, lecz do wszystkich zebranych. Ostatnie ujęcie kamery przedstawia go leżącego na plecach, na deskach areny, z rozłożonymi rękami, w pozycji przypominającej krzyż. Po końcowych słowach Hamleta: „reszta jest milczeniem” (5.2.750) komnatę wypełnia żałobna cisza. Kamera oddala się od niego, by z lotu ptaka ukazać wstrząsający widok poległych tam postaci. Sekwencja finałowa $\mathrm{w}$ adaptacji Zeffirellego to jedna $\mathrm{z}$ nielicznych sekwencji (i pod tym względem podobna do sceny początkowej), w których postaci są unieruchomione i bezdźwięczne. Nasuwa się też stwierdzenie, że Zeffirelli przede wszystkim wykorzystuje w swojej adaptacji, stylizowanej na film akcji, warstwę obrazową, którą należy wielokrotnie rozszerzać o znaczenia metaforyczne. Pokazuje to scena końcowa, wstrzymująca akcję nie tylko ze względu na tragiczny finał, lecz odpowiednie rozmieszczenie i ułożenie martwych postaci oraz spowolnione tempo kamery aż do całkowitego jej zatrzymania.

Branagh natomiast decyduje się po raz kolejny umieścić akcję w sali tronowej w otoczeniu dworzan. Pojedynek Hamleta z Laertesem rozgrywa się w centrum uwagi, czyli na środku komnaty na czerwonym dywanie. U Branagha pojedynek jest pomyślany jako popis zdolności szermierczych Hamleta. Jest to realizacja wizerunku Hamleta jako żołnierza i elokwentnego księcia. W takim przedstawieniu postaci można dostrzec uosobienie frazeologicznego wyrażenia „słowna szermierka”. Hamlet przede wszystkim ma okazję oddziaływać spektakularnym występem, karmiąc ciągle „nienasycone oczy” Elsynoru. Z kolei Klaudiusz wykorzystuje pojedynek do sfinalizowania misternie uplecionej intrygi, by pozbyć się bratanka. Król objaśnia ceremonialny charakter wypicia wina z perłą, które jest przeznaczone dla Hamleta. W tej adaptacji scena finałowa staje się przede wszystkim pojedynkiem percepcyjnym między Hamletem a Klaudiuszem.

Rolę spełnianą przez Gertrudę można określić jako rolę kolejnej kobiecej ofiary zepsutego systemu patriarchalnego na duńskim dworze. Wątek przypadkowego otrucia królowej przybiera u Branagha formę nieświadomego wypicia przez nią zatrutego wina. Kamera pokazuje, jak królowa zabiera Klaudiuszowi kielich i podchodzi z nim do Hamleta - wznosząc toast za przewidywaną wygraną syna i ignorując bardzo wyraźną uwagę męża, by nie piła napoju. Mimo że jego „nienaturalny” ton głosu zwraca uwagę wszystkich zebranych, Gertruda upija trochę wina. Resztę podaje Hamletowi, a po jego odmowie, chustą wyciera mu twarz i powraca na swoje miejsce, by zasiąść 
obok przyglądającego się jej Klaudiusza. 0 otruciu winem królowa informuje Hamleta tuż przed swoją śmiercią. Choć ton jej głosu nie jest oskarżycielski w stosunku do pochylonego nad nią męża, wydaje się, że odkryła jego spisek. Zamiast w stronę Klaudiusza, ostatnie spojrzenie i słowa kieruje do Hamleta. Po ujawnieniu winowajcy przez Laertesa Hamlet zabija stryja, rzucając ze sporej odległości szpadą i podając mu resztkę toksycznego wina. Branagh unika krwi w scenie finałowej i poza pokazaniem, na przykład, lekkiego draśnięcia ramienia Hamleta, bohaterowie umierają praktycznie bezkrwawo. Być może obraz Hamleta konającego na czerwonym dywanie ma oddać faktyczny charakter zbrodni.

Ostatnie ujęcie w filmie, już po przejęciu władzy przez Fortynbrasa (Branagh bardzo intensywnie rozbudowuje ten wątek), przedstawia uroczysty pogrzeb Hamleta. Trumna ze zwłokami bohatera zostaje umieszczona na podwyższeniu, zaś wszyscy uczestnicy ceremonii ubrani są w długie, czarne płaszcze. Jasne włosy Hamleta i zimowy krajobraz kontrastują z żałobnymi barwami, w które przyobleka się Elsynor. Na koniec kamera oddala się od trumny i wędruje w stronę posągu ojca Hamleta. Symboliczne obalenie dawnej władzy przedstawia ujęcie, w którym dawna statua króla zostaje obalona i potłuczona na kawałki. Branagh powraca do tego samego motywu, który zainicjował fabułę filmu - do wielkiego napisu „HAMLET”, znajdującego się pod pomnikiem. Ostatecznie napis zostaje częściowo przesłonięty przez spadającą głowę posągu. Wywołuje to następujący efekt: napis „HAMLET” zostaje uzupełniony (nie zastąpiony) obrazem powalonego, posągowego ciała dawnego władcy. Szczególnie istotny wydaje się fragment „odrąbanej” głowy, leżący tuż obok wspomnianego napisu. Ostatecznie słowo („HAMLET”) i obraz (głowa króla) tworzą całość, a przecież na tym właśnie polega strategia filmowa Branagha.

U Almereydy scena pojedynku jest wkomponowana $\mathrm{w}$ postmodernistyczny krajobraz adaptacji. Reżyser umieszcza bohaterów na dachu drapacza chmur w obecności fotoreporterów i podłącza Hamleta oraz Laertesa do elektronicznych urządzeń, które monitorują przebieg szermierczego starcia. Na uwagę zasługuje dynamiczna praca kamery w tej scenie ze względu na konieczność pokazania finałowych oddziaływań percepcyjnych między postaciami. Przede wszystkim perspektywa Gertrudy ulega przemianie, kiedy odkrywa ona, że wino, którym Klaudiusz dwukrotnie częstuje jej syna, musi zawierać jakąś niebezpieczną substancję. O „olśnieniu” Gertrudy świadczą jej spojrzenia w stronę Klaudiusza i kielicha. Król jednak nie orientuje się, że podstęp został odkryty. Kiedy powtórnie proponuje Hamletowi trujący napój, Gertruda podbiega w stronę syna, zapobiegając podaniu mu kielicha. Po chwili sama wyrywa Klaudiuszowi wino i upija jego zawartość, patrząc mężowi prosto w oczy. Do niego też adresuje słowa: „Piję, chciejcie mi wybaczyć" (5.2.672). Choć Klaudiusz na czas nie ostrzega jej, by nie piła, jego 
wyraz twarzy i gest wyciągnięcia rąk w kierunku kielicha oznaczają, że chciał zareagować. Gertruda podchodzi do Hamleta, proponując mu otarcie twarzy chusteczką, jednak syn wydaje się niechętny nawiązaniu z nią bliskości, również jego wzrok „ucieka” od matki. Ostatecznie, w symbolicznym pojednaniu widać, jak Hamlet na moment przytula się do niej. Odmieniona Gertruda powraca na swoje miejsce i dalej przygląda się pojedynkowi.

Zamiast otrutego ostrza szpady, Almereyda wykorzystuje w scenie zabójstwa Hamleta pistolet. Słychać wystrzał i po chwili na białych strojach Hamleta i Laertesa pojawiają się strugi krwi. Równocześnie Gertruda zaczyna odczuwać skutki działającej w jej organizmie trucizny. Milcząco, po raz ostatni odwzajemnione spojrzenie kieruje w stronę swojego syna. Klaudiusz próbuje zbiec, jednak nie udaje mu się uniknąć kuli wystrzelonej przez Hamleta. Almereyda pokazuje, jak bezwzględny szef korporacji „Dania”, ustawiony tyłem do kamery, osuwa się przy balustradzie wysokościowca, a znikając z pola widzenia, pozostawia przed sobą widok mrocznych okien Nowego Jorku.

Na zakończenie bohater decyduje się powierzyć Horacjowi misję opowiedzenia jego historii. Almereyda zaś ukazuje wspomnienia widziane „oczami wyobraźni" Hamleta. Jak zauważa Burnett:

W chwili śmierci, Hamlet zostaje ukazany, jak przegląda - w przyspieszonym tempie - zmontowane, najważniejsze wydarzenia zarówno z filmu, jak i z własnego życia. Poprzez akcję zemsty, odrzuconą wcześniej konwencję filmową, bohater jest zdolny do tego, by percepcyjnie „sporządzić mapę” opowieści, którą zainaugurował filmem-w-filmie (Bunett, 2003: 62).

Badacz podkreśla, że Hamlet ma już zapisane w swoim „oku umysłu” te obrazy, które wcześniej utrwalał okiem kamery (2003: 63). A są to czarno-białe wspomnienia przedstawiające między innymi Ofelię, Gertrudę i jego ojca. Najistotniejszy dla bohatera pozostaje obraz, bo postacie z jego ostatniego, mentalnego filmu pozostają nieme, choć istnieją w sposób uchwytny wzrokowo. Można wysunąć stwierdzenie, że mimo współczesnego obsesyjnego zainteresowania „elektronicznymi oczami”, i tak nie zastąpią one percepcji ludzkiego oka. 



\section{Zakończenie, czyli dlaczego Hamlet (jest) uzmysłowiony}

Trudności w uzmysłowieniu sobie zmysłów biorą się między innymi stąd, że w szczególny sposób angażują obiekt analizy i refleksji. Jeśli dodatkowo potraktować zmysły i same organy postrzegania jako część kultury, czyli element wymuszający odmienne niż biologicze podejście naukowe, wówczas stykamy się z fenomenem ludzkiego istnienia, opartego na działaniu czegoś, czego efektem są efemeryczne doświadczenia. Choć nigdy nie dowiem się od Szekspira, czym było dla niego widzenie zachodu słońca czy słyszenie głosu aktora, wyszłam z założenia, że może chociaż spróbuję zinterpretować, co z tak ulotnych zachowań percepcyjnych mogło zachować się w kanonicznym tekście dla kultury Zachodu. Być może rozwodzenie się nad zmysłami jest nieuzasadnione, bo, jak precyzyjnie ustalić sensy nadawane im przez ludzi z dawnych epok na podstawie materiałów literackich, filozoficznych oraz medycznych i nie popaść w zatracenie się we współczesnej perspektywie? Z drugiej strony - czemu mniej uprawnionym przedmiotem badań mają być zmysły chociażby w porówaniu z ludzkim myśleniem? A przecież to ostatnie także sprawia li i tylko wrażenie ciągłości i niezachwianej doniosłości dla istnienia, będąc w centrum zainteresowań badawczych znacznie częściej niż zmysły. Historia ludzkiego myślenia mogłaby wydawać się dłuższa i bogatsza niż historia zmysłów: czy to paralogizm, czy sofizm?

Starając się patrzeć ex post na teksty kultury, z których wyłania się wiedza na temat zmysłów, wydaje się, że właśnie poprzez te zapisy ludzie starali się uzmysłowić sobie zmysły. Oczywiście Hamlet nie jest jedynie „dramatem zmysłów", lecz pozwala na takie odczytanie. Podobnie teoria Kartezjusza nie dążyła do opisu zjawisk związanych z postrzeganiem sensorycznym, lecz częściowo takie podejście wypreparowowała. Z kolei współczesne adaptacje Hamleta nie sprawdzają się jako wizualne opowieści o ludzkim sensorium, jedynie zachęcają do podjęcia wątku reprezentacji zmysłów w nich przedstawionych. Hamlet uzmysłowiony nie jest ścisłą analizą tekstu, nie jest też stricte pracą z zakresu filmoznawstwa, a raczej projektem z pogranicza orientacji 
badawczych, który uwzględnia różnicę pomiędzy reprezentacjami zmysłów w dwóch wymiarach funkcjonowania Hamleta w kulturze, z dodatkowym istotnym rozróżnieniem - wpływem różnicy płci poszczególnych postaci dramatu na reprezentacje doświadczeń angażujących zmysły. Rezultatem badawczym jest takie spojrzenie (by posłużyć się określeniem o zabarwieniu wizualnym) na uzmysłowiony dramat Szekspira, które potencjalnie może zaznaczyć się na polu badań nad Hamletem jako praca łącząca perspektywę genderowo-feministyczną z elementami antropologii kulturowej.

Wydobycie i wyeksponowanie fizycznego wymiaru istnienia jednostki ludzkiej w literaturze i filmie umożliwiło mi spojrzenie na historycznie zmienne „barwy znaczeń" przypisywanych zmysłom. Owa paleta kolorystyczna powstaje w wyniku wymieszania wartości i kontekstów społecznych, rozszerzonych o

porządek wiedzy wpisany w kolejne poetyki historyczne, w których zostały utrwalone wyobrażenia o naturze człowieka charakterystyczne dla danego okresu literackiego. Owe reprezentacje łączą sferę literacką i kontekst pozaliteracki, odnoszą się bowiem do problematyki istotnej dla klimatu duchowego okresu, w którym powstały (Rembowska-Płuciennik, 2006: 329).

Tekst filmowy poniekąd stanowi literacką formę (w postaci samego scenariusza), dlatego słuszne wydaje się podkreślenie wspólnej płaszczyzny adaptacji i dzieła literackiego na poziomie słowa pisanego. Stąd też powyższy cytat może odnosić się zarówno do tekstu Hamleta, jak i jego adaptacji. Na światy w nich przedstawione składają się liczne reprezentacje, między innymi wspomniane konstrukcje zmysłów, które zostały rozróżnione na literackie i filmowe. Owa odmienność, wynikająca z różnic konwencji literackich i filmowych, ma istotny wpływ na interpretację literackich opisów (fabuła poetycka) oraz ich filmowych ujęć (fabuła filmowa). Określone sposoby reprezentacji zmysłów w dramacie, jak na przykład zastosowanie wyrażeń percepcyjnych w tekście Hamleta, czy też wykorzystanie ujęć eksponujących doświadczenia z wykorzystaniem zmysłów na ekranie, ukazały różnice w ich obrazowaniu.

Skoncentrowanie się na zjawiskach „zmysłowych preferencji” kulturowych, rozumianych jako teorie i praktyki społeczne, w tym zwłaszcza w tak odległych od siebie czasowo epokach jak renesans i postmodernizm, pozwoliło udowodnić, że stanowią one określone, ewoluujące w kierunku wzrokocentryzmu porządki kulturowe oparte na zmysłach. Wykorzystanie teoretycznych założeń metodologii badań sensorycznych w szczegółowej analizie tekstu tragedii Hamlet oraz wybranych filmowych adaptacjach tego dzieła, pozwoliło na swoiste przewartościowanie dotychczasowych interpretacji. W wyniku analizy Hamleta doszłam zatem do wniosku, że wczesna nowożytność to okres liminalny, zawieszony pomiędzy przedkartezjańskim a kartezjańskim pojmowaniem zmysłów oraz między późnoakustyczną 
a wczesnowizualną istotą samej kultury renesansowej. Szekspir, który tworzył w okresie transformacyjnym pod względem konceptualizacji zmysłów, zawarł w omawianym dramacie ówczesne, niestabilne i pełne niewiadomych, podejście do ludzkiego sensorium. Poszczególni bohaterowie dramatu, zróżnicowani charakterologicznie i genderowo, w różny sposób wykorzystują aparat zmysłowy, rozumiany jako kulturowo skonstruowane narzędzie poznawcze. Szekspir, kreując w dramacie kalejdoskop fikcyjnych postaci, które w sposób sensualny doświadczają rzeczywistości, być może zademonstrował preferencje zmysłowe ówczesnych uczestników i nośników kultury. Ponadto omówione w książce praktyki sensualnego odbioru sztuk teatralnych oraz szczegółowo zaprezentowana teoria sensoryczna, potwierdzają tezę o manifestowalnym w Hamlecie życiu sensualnym ludzi funkcjonujących w czasach wczesnej nowożytności.

Adekwatnie do wniosków płynących z przestudiowania tekstu pojawiają się konkluzje dotyczące analiz filmowych Hamleta. Trzy wybrane adaptacje filmowe oddają charakter współczesnej kultury percepcyjnej. Mianowicie wpisują się one w okulocentryczne realia postmodernizmu, a dowodem tego jest uwypuklenie przez Zeffirellego, Branagha i Almereydy, dominującego w teraźniejszej kulturze, zmysłu wzroku. Tym razem to ekranowi bohaterowie posługują się zmysłami w celach poznawczo-emocjonalnych. Ich preferencje w zakresie wykorzystania wzroku bądź słuchu mogą zaświadczać o podobnych, rzeczywistych percepcyjnych wyborach współczesnego homo sapiens, będącego zarówno odbiorcą, jak i twórcą kultury percepcyjnej swoich czasów.

Badania, które podejmują problematykę reprezentacji zmysłów na poziomie tekstu oraz na ekranie filmowym, to próba połączenia dwóch wymiarów funkcjonowania Hamleta, mianowicie w kulturze wczesnej nowożytności (tekst) oraz w kulturze współczesnej (film). Wynika to z faktu, że każdy Hamlet, rozumiany jako wytwór kulturowy swoich czasów, podlega innemu porządkowi sensualnemu, i w taki sam sposób porządek ten wytwarza. 0 ile w czasach szekspirowskich wystawienia dramatu były przeżyciem słuchowo-wzrokowym, bazującym na dostępnych ówcześnie formach przekazu wzrokowego i audialnego (z perspektywy XXI wieku - formach praktycznie niezmediatyzowanych), o tyle obecne adaptacje filmowe zaświadczają o dominacji wizualnego odbioru sztuki, o zapośredniczonym odbiorze świata, jak chociażby w przypadku filmowych odczytań. Nie oznacza to „niesłyszenia”, a raczej „niedosłyszenie” na korzyść „hiperwidzenia”. Współczesny kontekst kulturowej zmysłowości wymusił konieczność przeorganizowania ludzkiego sensorium i wyostrzenie tych aspektów zmysłowych, które najczęściej uczestniczą w życiu codziennym. Praktykowanie zmysłami to obecnie najczęściej praktykowanie wzrokiem, któremu nie tylko najczęściej ufamy i na nim polegamy, ale i pozwoliliśmy, by zawładnął językowymi realiami, a także królestwem artystycznym. 
Współczesny wizualny paradygmat percepcyjny wspierają omawiane w pracy adaptacje Hamleta. Zeffirelli, Branagh i Almereyda wyróżniają ten element poetyki dzieła filmowego, który odsyła do zmysłu wzroku. W kolejności są to więc: pierwszoplanowość motywu spojrzenia (Hamlet wyreżyserowany w 1990 roku), motywu lustra (produkcja Hamleta z 1996 roku) i motywu obiektywu (Hamlet milenijny). To, co wizualne - dostępne dla oczu, odbite przez lustrzane powierzchnie, czy też rejestrowane przez obiektywy kamer - zarówno w sensie dosłownym, jak i przenośnym - nabiera w analizowanych adaptacjach szczególnego znaczenia kulturowego.

Zarówno literatura, jak i film jawią się jako terytoria komunikowania znaczeń z zakresu ludzkiego postrzegania zmysłami. Dzięki istnieniu Hamleta w literaturze i w filmie możliwe staje się kulturowe przekazywanie wiedzy na temat ludzkiego poznania, różnego w zależności od płci społeczno-kulturowej. Ponadto konstrukcja kobiecych i męskich sposobów postrzegania za pomocą słuchu i wzroku pokazuje, że zarówno tekstualny, jak i filmowy kod sensoryczny każdego Hamleta omawianego w niniejszej pracy, odzwierciedla społeczne nierówności w dostępności do praktyk angażujących zmysły. Sensorycznie oznakowana płeć społeczno-kulturowa posiada określony repertuar zachowań percepcyjnych, dostępny kobietom i mężczyznom w danej epoce. Utrwalenie ulotnych doświadczeń zmysłowych w postaci literackich i filmowych reprezentacji wzroku i słuchu pozwala dotrzeć do życia sensualnego ludzi żyjących w czasach Szekspira, a także lepiej zrozumieć współczesną kulturę percepcyjną zachodniego kręgu kulturowego.

Być może w Hamlecie Szekspir eksperymentuje z własnymi/bohaterów/widza zmysłami, odrywając je raz po raz od świata natury. Peregrynacje w głąb kultury, oczywiście, jeśli skutecznie wykorzysta się własne sensorium, czy to za pomocą Mony Lizy literatury, czy też innego dzieła, mogą stanowić nie tylko ciekawe doświadczenie dla czytelnika lub widza (w przypadku adaptacji), ale też stanowić przyczynek do badań nad stopniem i charakterem uzmysłowienia własnego świata kulturowego. 


\section{Summary}

Sensing (Sensuous) „Hamlet” aims at making a comparison between the textual version of the play written by William Shakespeare and its cinematic renditions, namely: Franco Zeffirelli's (1990), Kenneth Branagh's (1996) and Michael Almereyda's (2000). The book is divided into introduction, five chapters: "Cultural architecture of the senses"; "Remains of sensual life of the people from the past", "The senses in early modern theatre, philosophy and medicine"; "The tragedy of Hamlet as the tragedy of the senses"; "The senses on screen: new sensuality of Hamlet", and conclusions. I pose a pivotal question why Hamlet is sensuous and how one should sense it. I assume that both literature and film might be treated as territories that convey meanings of human sensory perception. I trace these meanings and cultural values that are hidden behind them by analyzing selected Hamlet(s), scene by scene. My investigation is grounded in sensory studies, new theoretical terrain which renders any sensory analysis possible.

The senses are understood as cultural formations undergoing changes in time. The evolution of cultural interpretation of the senses is thus inevitable. Such cultural texts as Hamlet-the drama or Hamlet-the film are regarded as sources of knowledge, also about the senses. Although sensory experiences are volatile and passing, they remain in form of literary or cinematic representations. It is noteworthy that in my analysis I purposely exploited the method that complies with gendering of the senses. The construction of male and female ways of sensing as well as a division into the senses associated either with women (touch, smell and taste) or men (sight and hearing) contributed to creating a gender-oriented examination of the senses in early modern and contemporary times. Cultural imagining of the senses is feasible due to the existence of various Hamlets, being in constant dialogue with each other, that is to say, in intertextual relations. The sensory code of Hamlet is a complex composition that still bothers our minds (and senses).

The title is a word play that pertains to a twofold nature of the drama: Hamlet is a play to be sensed (grasped, also with the help of our senses) and simultaneously Hamlet is sensuous - abundant in sensory imagery, a key to decipher the mystery of Hamlet's popularity and its mesmerizing qualities. 



\section{Bibliografia}

\section{Źródła prymarne}

\section{Dramaty}

Shakespeare, W., Hamlet. The Arden Shakespeare, Third Series, Ann Thompson i Neil Taylor Sonety (red.), London: Thomson Learning, 2007

Szekspir W., Sonety, tłum.: Maciej Słomczyński, Kraków: Wydawnictwo Cassiopeia, 1992

\section{Tłumaczenia}

Szekspir W., Hamlet, tłum:. Stanisław Barańczak, Kraków: Znak 2000

Szekspir W., Hamlet, tłum.: Józef Paszkowski, Warszawa: PIW, 1970

Szekspir W., Hamlet, tłum:. Władysław Tarnawski, Wrocław: Zakład im. Ossolińskich, 1966

\section{Zbiory wierszy}

Barańczak S., Jednym tchem, Warszawa: Zrzeszenie Studentów Polskich, „Orientacja”, 1970

Szymborska W., Wiersze wybrane, Kraków: Wydawnictwo a5, 2010

\section{Filmografia}

Hamlet (Wielka Brytania, 1990) - reż. Franco Zeffirelli

Hamlet (Wielka Brytania, 1996) - reż. Kenneth Branagh

Hamlet (USA, 2000) - reż. Michael Almereyda

\section{Źródła sekundarne}

\section{Monografie i opracowania}

Arendt H. Myślenie, tłum. Hanna Buczyńska-Garewicz, Warszawa: Czytelnik, 2000

Aronson A., Shakespeare and the Ocular Proof, New York: Vantage Press, 1995

Bordieu P., Męska dominacja, tłum. Lucyna Kopciewicz, Warszawa: Oficyna Naukowa, 2004

Bourus T., Shakespeare in Performance: "Hamlet", Manchester: Manchester University Press, 1995

Brode D., Shakespeare in the Movies: From the Silent Era to the Shakespeare in Love, Oxford: Oxford University Press, 2000

Buhler S. M., Shakespeare in the Cinema: Ocular Proof, Albany: State University of New York Press, 2002

Burton R., The Anatomy of Melancholy, New York: Farrar \& Rinehart, Inc., 1927

Callaghan D. (red.), A Feminist Companion to Shakespeare, Oxford-Malden- Massachusetts: Blackwell Publishers, 2000 
Cartelli T., Rowe K., New Wave Shakespeare on Screen, Cambridge-Malden-MA: Polity Press, 2007

Cartmell D., Interpreting Shakespeare on Screen, London: Palgrave Macmillan, 2000

Charney M., Shakespeare's Roman Plays: The Function of Imagery in the Drama, Cambridge: Harvard University Press, 1961

Chillington Rutter C., Enter the Body: Women and Representation on Shakespeare's Stage, London-New York: Routledge, 2000

Clark S., Vanities of the Eye: Vision in Early Modern European Culture, Oxford: Oxford University Press, 2007

Classen C., The Color of Angels. Cosmology, Gender and the Aesthetic Imagination, New York: Routledge, 1998

- ----------Worlds of Sense: Exploring the Senses in History and Across Cultures, London: Routlege, 1993

Clemen, W., The Development of Shakespeare's Imagery. London: Methuen, 1967

Collick J., Shakespeare, Cinema and Society, Manchester: Manchester University Press, 1989

Connor S., The Book of Skin, Ithaca, New York: Cornell University Press, 2003

Cowden Clarke M., The Girlhood of Shakespeare's Heroines, Cambridge: Cambridge University Press, 2009

Cox L. S., Figurative Design in "Hamlet": The Significance of the Dumb Show, Columbus: Ohio State University Press, 1973

Craik K. A., Reading Sensations in Early Modern England, New York: Palgrave Macmillan, 2007

Crombie A. C., Science, Optics and Music in Medieval and Early Modern Thought, London, Ronceverte: Hambledon Press, 1990

Crowl S., Shakespeare at the Cineplex: The Kenneth Branagh Era, Athens: Ohio University Press, 2003

Crowl S., The Films of Kenneth Branagh, Westport: Praeger, 2006

Cavallaro D., French Feminist Theory, London: Continuum, 2003

Diede M. K., Shakespeare's Knowledgeable Body, New York: Peter Lang, 2008

Dusinberre J., Shakespeare and the Nature of Women, London: Macmillan, 1975

Dziechcińska H., Ciało, strój, gest w czasach renesansu i baroku, Warszawa: Semper, 1996

Eisaman Maus K., Inwardness and Theater in the English Renaissance, Chicago-London: The University of Chicago Press, 1995

Eliot T. S., Selected Prose of T.S. Eliot, Kermode Frank (red.), London: Faber, 1975

Fox A., Oral and Literate Culture in England 1500-1700, Oxford: Clarendon Press, 2000

Freud Z., Objaśnianie marzeń sennych, tłum. Robert Reszke, Warszawa: KR Wydawnictwo, 2007

Garber M., Coming of Age in Shakespeare, London-New York: Methuen, 1981

Greenblatt S. J., Shakespearean Negotiations: The Circulation of Social Energy in Renaissance England, Berkeley: University of California Press, 1988

Gross K., Shakespeare's Noise, Chicago: University of Chicago Press, 2001

Gurr A., Playgoing in Shakespeare's London, Cambridge: Cambridge University Press, 2004

Hall E., Ukryty wymiar, tłum. Teresa Hołówka, Warszawa: Muza SA, 2001

Harvey D. E., Ventriloquized Voices: Feminist Theory and English Renaissance Texts, LondonNew York: Routledge, 1992

Hatchuel S., Shakespeare From Stage to Screen, Cambridge: Cambridge University Press, 2004

Hillman D., Shakespeare's Entrails. Belief, Scepticism and the Interior of the Body, BasingstokeHampshire-New York: Palgrave Macmillan, 2007

Hirsch J., Shakespeare and the History of Soliloquies, Madison-New Jersey: Fairleigh Dickinson University Press, 2003

Holland, N. N., Psychoanalysis and Shakespeare, New York and London: McGraw-Hill Book Company, 1966 
Howes D., Sensual Relations. Engaging the Senses in Culture and Social Theory, Ann Arbor-MI: University of Michigan Press, 2003

Hutcheon L., A Theory of Adaptation, New York: Routledge, 2006

Jay M., Downcast Eyes: The Denigration of Vision in Twentieth-Century French Thought, California: University of California Press, 1994

Johns A., The Nature of the Book: Print and Knowledge in the Making, Chicago: University of Chicago Press, 1998

Jütte R., A History of the Senses: From Antiquity to Cyberspace, Cambridge: Polity Press, 2005

King R. H. A, Common to Body and Soul: Philosophical Approaches to Explaining Living Behaviour in Antiquity, Berlin: De Gruyter, 2005

Kołos S., Nowe kino szekspirowskie: adaptacje sztuk Williama Szekspira w kinie lat dziewięćdziesiątych, Rabid: Kraków, 2007

Kujawińska Courtney K., „Th' Interpretation of the Time”: The Dramaturgy of Shakespeare's Roman Plays (ELS Monograph Series No. 57), Victoria: The University of Victoria, 1993

Lindberg D. C., The Beginnings of Western Science: European Scientific Tradition in Philosophical, Religious and Institutional Context, 600 BC to AD1450, Chicago-London: University of Chicago Press, 1992

Luckyj Ch., „A Moving Rhetoricke”: Gender and Silence in Early Modern England, ManchesterNew York: Manchester University Press, 2002

Mahood M. M., Shakespeare's Wordplay, London: Routledge, 1968

Marcus L. S., Unediting the Renaissance: Shakespeare, Marlowe, Milton, New York-London: Routledge, 1996

McEvoy S., Shakespeare: The Basics, London: Routledge, 2006

- --------William Shakespeare's „Hamlet”: A Routledge Study Guide and Sourcebook, London: Routledge, 2006

Meek R., Narrating the Visual in Shakespeare, Farnham-Burlington: Ashgate, 2009

Miola R., Shakespeare's Reading, Oxford: Oxford University Press, 2000

Palmer B., Nineteenth-Century American Fiction on Screen, New York: Cambridge University Press, 2007

Pearce J., Through Shakespeare's Eyes, San Francisco: Ignatius Press, 2010

Pollard T., Drugs and Theater in Early Modern England, Oxford: Oxford University Press, 2005

Porter R., Szaleństwo. Rys dziejów, Poznań: Rebis, 2003

Reinhard Lupton J., Reinhard K., After Oedipus: Shakespeare in Psychoanalysis, Ithaca: Cornell University Press, 1993

Rembowska-Płuciennik M., Poetyka i antropologia. Cykl podolski Włodzimierza Odojewskiego. Kraków: Universitas, 2004

Sawday J., The Body Emblazoned: Dissection and the Human Body in Renaissance Culture, London-New York: Routledge, 1995

Schoenfeld M. C., Bodies and Selves in Early Modern England: Physiology and Inwardness in Spenser, Shakespeare, Herbert, and Milton, Cambridge: Cambridge University Press, 1999

Selleck N., The Interpersonal Idiom in Shakespeare, Donne, and Early Modern Culture, New York: Palgrave, 2008

Smith M. M., How Race Is Made: Slavery, Segregation, and the Senses, Chapel Hill: University of North Carolina Press, 2006

- ----------Sensory History, Oxford: Berg, 2007

Spurgeon C., Shakespeare's Imagery and What It Tells Us. London: Oxford University Press, 1958

Thorne A., Vision and Rhetoric in Shakespeare: Looking through Language, Basingstoke: Palgrave Macmillan, 2000 
Webb J., Understanding Representation, London: Sage, 2008

Weimann R., Author's Pen and Actor's Voice: Playing and Writing in Shakespeare's Theatre, Cambridge: Cambridge University Press, 2000

West-Pavlov R., Bodies and their Spaces: System, Crisis, and Transformation in Early Modern Theatre, Amsterdam-New York: Rodopi, 2006

Wilson J. D., What Happens in Hamlet, Cambridge: Cambridge University Press, 1935

Wilson R. R., Shakespearean Narrative, Newark: University of Delaware Press, 1995

Worthen W. B., Shakespeare and the Force of Modern Performance, Cambridge-New York-Oakleigh: Cambridge University Press, 2003

Zamir T., Double Vision: Moral Philosophy and Shakespearean Drama, Princeton-Oxford: Princeton University Press, 2007

Zawisławska M., Czasowniki oznaczające percepcję wzrokowq we współczesnej polszczyźnie: ujęcie kognitywne, Warszawa: Wydział Polonistyki Uniwersytetu Warszawskiego, 2004

\section{Prace zbiorowe}

Bolecki W., Dąbrowska E. (red.), Literatura i wiedza, Warszawa: IBL PAN, 2006

Bull M., Back, L. (red.), The Auditory Culture Reader, Oxford: Berg, 2004

Burnett M. T., Manning J. (red.), The Hamlet Collection 1: New Essays on Hamlet, New York: AMS, 1994

Burnett M. T., Wray R. (red.), Screening Shakespeare in the Twenty-First Century, Edinburgh: Edinburgh University Press, 2006

Burt R. (red.), Shakespeare After Mass Media, New York-Houndmills-Basingstoke: Palgrave, 2002

Clarke D., Clarke E. (red.), This Double Voice: Gendered Writing in Early Modern England, Basingstoke-New York: Macmillan, 2000

Classen C. (red.), The Book of Touch, Oxford: Berg, 2005

Classen C., Howes D., Synnott A. (red.), Aroma: The Cultural History of Smell, London: Routlege, 1994

Collier J. Jr., Collier M. (red.), Visual Anthropology. Photography as a Research Method, Albuquerque: University of New Mexico Press, 1986

Croteau M., Jess-Cooke C. (red.), Apocalyptic Shakespeare: Essays on Visions of Chaos and Revelation in Recent Film Adaptations, Jefferson-North Carolina: McFarland, 2009

Dawson A. B., Hamlet. Shakespeare in Performance, New York: Manchester UP, 1995

Debru C. (red.), Essays in the History of Physiological Sciences, Amsterdam: Rodopi, 1995

Desmet Ch., Sawyer R. (red.), Shakespeare and Appropriation, London-New York: Routledge, 1999

Drobnick J. (red.), The Smell Culture Reader, Oxford: Berg, 2006

Dunn L. C., Jones N. A. (red.), Embodied Voices. Representing Female Vocality in Western Culture, Cambridge: Cambridge University Press, 1994

Dutton R., Howard J. E. (red.), A Companion to Shakespeare's Works: Volume 1. The Tragedies, Oxford: Blackwell, 2003

Edelson M. (red.), Studies in Literature and Culture, Łódź: Wydawnictwo Uniwersytetu Łódzkiego, 200

Edwards E. (red.), Visual Sense - A Cultural Reader, Oxford: Berg, 2008

Fischer G., Greiner B. (red.), The Play within the Play: The Performance of Meta-Theatre and SelfReflection, Amsterdam-New York: Rodopi, 2007

Hartman G. H., Parker P. (red.), Shakespeare and the Question of Theory, London-New York: Methuen, 1985

Holland P. (red.), Shakespeare, Memory and Performance, Cambridge, New York, Oakleigh: Cambridge University Press, 2006

- ---------(red.), Writing about Shakespeare, Cambridge: Cambridge University Press, 2006

Howes D. (red.), Empire of the Senses: The Sensual Culture Reader, Oxford: Berg, 2005 
Huang A. C. Y., Ross Ch. S. (red.), Shakespeare in Hollywood, Asia, and Cyberspace, West Lafayette: Purdue University Press, 2009

Jackson R. (red.), The Cambridge Companion to Shakespeare on Film, Cambridge: Cambridge University Press, 2007

Kempny M., Nowicka E. (red.), Badanie kultury. Elementy teorii antropologicznej, Warszawa: PWN, 2004

Klein H., Daphinoff D. (red.), Hamlet on Screen. Shakespeare Yearbook 8, New York: The Edwin Mellen Press, 1997

Klein H., Harner J. L (red.), Shakespeare and the Visual Arts: Shakespeare Yearbook 11, Lewiston: The Edwin Mellen Press, 2000

Korsmeyer C. (red.), The Taste Culture Reader, Oxford: Berg, 2005

Kujawińska Courtney K. (red.), On Page and Stage: Shakespeare in Polish and World Culture, Kraków: Towarzystwo Autorów, 2000

Legeżyńska A., Czapliński, P., Telicki M. (red.), Jaka antropologia literatury jest dzisiaj możliwa?, Poznań: Poznańskie Studia Polonistyczne, 2010

Lehmann C., Starks L. S. (red.), Spectacular Shakespeare: Critical Theory and Popular Cinema, Madison-Teaneck: Fairleigh Dickinson University Press, 2002

Limon J., Halio J. L. (red.), Shakespeare and His Contemporaries. Eastern and Central European Studies, Newark: University of Delaware Press, 1993

McLuhan M., Zingrone F. (red.), McLuhan - Wybór tekstów, Poznań: Zysk i S-ka, 2001

Nasiłowska A. (red.), Ciało i tekst. Feminizm w literaturoznawstwie - antologia szkiców, Warszawa: IBL, 2000

Porter R. (red.), Rewriting the Self: Histories from the Renaissance to the Present, London: Routledge, 1997

Richards J., Thorne A. (red.), Rhetoric, Women and Politics in Early Modern England, LondonNew York: Routledge, 2007

Sharpe K., Zwicker S. N. (red.), Reading, Society, and Politics in Early Modern England, Cambridge: Cambridge University Press, 2003

Smith M. M. (red.), Hearing History: A Reader, Athens: University of Georgia Press, 2004

Stam R., Raengo A. (red.), Literature and Film: A Guide to the Theory and Practice of Adaptation, Malden-MA-Oxford: Blackwell Publishing, 2005

Swift Lenz, C. R., Greene G., Neely C. T. (red.), The Woman's Part: Feminist Criticism of Shakespeare, Urbana: University of Illinois Press, 1980

\section{Eseje i artykuły}

Abbate A., „The Text within the Text, the Screen within the Screen: Multi-Layered Representations in Michael Almereyda's Hamlet and Baz Luhrmann's Romeo + Juliet", w: Gerhard Fischer i Bernhard Greiner (red.), The Play within the Play: The Performance of Meta-Theatre and Self-Reflection, Amsterdam-New York: Rodopi, 2007

- Film Quarterly 32.2 (2004): 82-89, http://findarticles.com/p/articles/mi_qa3768/ is_200401/ai_n9394414/print?tag=artBody;col1, 3.09.2008

Banks C., Holderness G., ,» Mine Eye Hath Play'd the Painter«", w: Holger Klein i James L. Harner (red.), Shakespeare and the Visual Arts: Shakespeare Yearbook 11, Lewiston: The Edwin Mellen Press, 2000: 454-473

Bourus T., „The First Quarto of Hamlet in Film: The Revenge Tragedies of Tony Richardson and Franco Zeffirelli", EnterText 1.2. (Spring 2001): 180-191

Bull, M., Gilroy, P., Howes, D., Kahn, D., „Introducing Sensory Studies”, The Senses and Society 1.1 (March 2006): 5-7

Burke P., „The Self from Petrarch to Descartes”, w: Roy Porter (red.), Rewriting the Self: Histories from the Renaissance to the Present, London: Routledge, 1997: 17-28 
Burnett M. T., „»I See My Father« in »My Mind's Eye«: Surveillance and the Filmic Hamlet", w: Mark Thornton Burnett i Ramona Wray (red.), Screening Shakespeare in the TwentyFirst Century, Edinburgh: Edinburgh University Press, 2006: 31-52

- ---------,»The Very Cunning of the Scene«: Kenneth Branagh's Hamlet", Literature/ Film Quarterly 27 (1997): 78-82

------------,»To Hear and See the Matter«: Communicating Technology in Michael Almereyda's Hamlet", Cinema Journal 42.3, (2003): 48-69

- --------,Writing Shakespeare in the Global Economy” w: Peter Holland (red.), Writing about Shakespeare, Cambridge: Cambridge University Press, 2006: 185-198

- Burt (red.), Shakespeare After Mass Media, New York-Houndmills-Basingstoke: Palgrave, 2002: 83-106

Caldwell M. L., „Hamlet and the Senses”, Modern Language Quarterly 40.2, (June 1979): 135-154

Campbell K., „Zeffirelli's Hamlet - Q1 in Performance”, Shakespeare on Film Newsletter 16.1 (1991): 7-8

Chillington Rutter C., „Snatched Bodies: Ophelia in the Grave”, Shakespeare Quarterly 49.3 (Autumn 1998): 299-319

Cieślak M., „Michael Almereyda's Hamlet - An Attempt at Hamlet”, Cadernos de Traduçao 7, (2001/1): 109-126

- ---------_Popularising Shakespeare - Franco Zeffirelli's Hamlet” w: Maria Edelson (red.), Studies in Literature and Culture, Łódź: Wydawnictwo Uniwersytetu Łódzkiego, 2002: 36-46

Classen C., „Foundations for an Anthropology of the Senses”, International Social Science Journal 153 (1997): 401-412

- -------_The Senses”, w: Peter N. Stearns (red.), „Encyclopedia of European Social History from 1350-2000, t. 4, New York: Gale, 2001: 355-364

Croteau M., „Celluloid Revelations: Millennial Culture and Dialogic »Pastiche« in Michael Almereyda's Hamlet (2000)", w: Melissa Croteau i Carolyn Jess-Cooke (red.), Apocalyptic Shakespeare: Essays on Visions of Chaos and Revelation in Recent Film Adaptations, Jefferson-North Carolina: McFarland, 2009: 110-31

Cummings P., „Hearing in Hamlet: Poisoned Ears and the Psychopathology of Flawed Audition”, Shakespeare Yearbook 1, (Spring 1990): 81-92

Dunn, L. C., „Ophelia's Songs in Hamlet: Music, Madness, and the Feminine”, w: Leslie C. Dunn i Nancy A. Jones (red.), Embodied Voices. Representing Female Vocality in Western Culture, Cambridge: Cambridge University Press, 1994: 50-64

Dunn L. C., Jones N.A., „Introduction”, w: Leslie C. Dunn i Nancy A. Jones (red.), Embodied Voices. Representing Female Vocality in Western Culture, Cambridge: Cambridge University Press, 1994: 1-13

Egan G., „Hearing or Seeing a Play? Evidence of Early Modern Theatrical Terminology”, The Ben Jonson Journal 8 (2001): 327-347

Fike M. A., „Gertrude’s Mermaid Allusion”, w: Krystyna Kujawinska Courtney (red.), On Page and Stage: Shakespeare in Polish and World Culture, Kraków: Towarzystwo Autorów, 2000: 259-275

Gibińska M., „»The Play's the Thing «: The Play Scene in Hamlet”, w: Jerzy Limon i Jay L. Halio (red.), Shakespeare and His Contemporaries. Eastern and Central European Studies, Newark: University of Delaware Press, 1993: 175-188

Gouk P., „English Theories of Hearing in the Seventeenth Century”, w: Mark M. Smith (red.), Hearing History: A Reader, Athens: University of Georgia Press, 2004: 136-150

Guntner J. Lawrence, „Hamlet, Macbeth and King Lear on Film”, w: Russel Jackson (red.), The Cambridge Companion to Shakespeare on Film, Cambridge: Cambridge University Press, 2007: 120-140 
Hall E., „Foreword”, w: John, Jr. Collier I Malcolm Collier (red.), Visual Anthropology. Photography as a Research Method, Albuquerque: University of New Mexico Press, 1986: xiii-xvii

Hassel R. Chris, „Painted Women: Annunciation Motifs in Hamlet”, Comparative Drama 32 (1998): 47-84

Howes D., „, Can These Dry Bones Live? An Anthropological Approach to the History of the Senses”, The Journal of American History (September 2008): 442-451

- ---------_Charting the Sensorial Revolution”, The Senses and Society 1.1 (March 2006): $113-128$

Hudson L., „The »Double Voice« of Renaissance Equity and the Literary Voices of Women”, w: Danielle Clarke, Elizabeth Clarke (red.), This Double Voice: Gendered Writing in Early Modern England, Basingstoke-New York: Macmillan, 2000: 142-163

Kelley Ch. G., „Lend Thy Serious Hearing To What I Shall Unfold: Legend Dynamics in Hamlet”, Hamlet Studies 21 (1999): 89-113

Kincaid A. N., „Hamlet's Cue for Passion in the Nunnery Scene”, Shakespeare Studies 10 (1977): 99-113

Lanier D., ,»Art Thou Base, Common and Popular?«: The Cultural Politics of Kenneth Branagh's Hamlet", w: Courtney Lehmann and Lisa S. Starks (red.), Spectacular Shakespeare: Critical Theory and Popular Cinema, Madison-Teaneck: Fairleigh Dickinson University Press, 2002: 149-171

- ----------,Shakescorp Noir”, Shakespeare Quarterly 53/2 (Summer, 2002): 157-180

Lawson Ch., „»A Palpable Hit«: Franco Zeffirelli's Hamlet (USA. 1990)”, w: Holger Klein i Dimiter Daphinoff (red.), Hamlet on Screen. Shakespeare Yearbook 8, New York: The Edwin Mellen Press, 1997: 230-249

Neely C. T., „Documents in Madness”: Reading Madness and Gender in Shakespeare's Tragedies and Early Modern Culture, Shakespeare Quarterly 42.3, (1991): 315-338

Norford D. P., ,»Very Like a Whale«: The Problem of Knowledge in Hamlet", ELH 46 (1979): 559-76

Owens J., „»Images, Images, Images«: The Contemporary Landscape of Michael Almereyda's Hamlet", Interdisciplinary Humanities 20.2. (October 2003): 21-27

Pajdzińska A., „Wrażenia zmysłowe jako podstawa metafor językowych”, Etnolingwistyka 8 (1996): 113-130

Przeźmiński J., „Z perspektywy Martina Jaya, czyli o tym jak »przymknąć oko«, w: Ryszard Nycz (red.), Odkrywanie modernizmu: przekłady i komentarze, Kraków: Universitas, 1998: 331-344

Rasmus A., ,»I could a tale unfold «: From Metatheatre to Metacinema: Films within the Films in Shakespeare on Screen", Cadernos de Traduçao 7, (2001/1): 147-167

Rembowska-Płuciennik M., „Dlaczego warto wrócić do zmysłów? Wokół literaturoznawczych inspiracji antropologią zmysłów”, w: Anna Legeżyńska, Przemysław Czapliński i Marcin Telicki (red)., Jaka antropologia literatury jest dzisiaj możliwa?, Poznań: Poznańskie Studia Polonistyczne, 2010: 129-139

- --cji w prozie psychologicznej dwudziestolecia międzywojennego)”, w: Władysław Bolecki i Elżbieta Dąbrowska (red.), Literatura i wiedza, Warszawa: IBL PAN, 2006: 328-345

Scolnicov H., „Intertextuality and Realism in Three Versions of Hamlet: The Willow Speech and the Aesthetics of Cinema", w: Holger Klein i James L. Harner (red.), Shakespeare and the Visual Arts: Shakespeare Yearbook 11, Lewiston: The Edwin Mellen Press, 2000: 227-237

Showalter E., „Przedstawiając Ofelię: kobiety, szaleństwo i zadania krytyki feministycznej”, w: Anna Nasiłowska (red.), tłum. Krystyna Kujawińska Courtney i Witold Ostrowski, Ciało $i$ tekst. Feminizm w literaturoznawstwie - antologia szkiców, Warszawa: IBL, 2000: 188-206

Smith R., „A Heart Cleft in Twain: The Dilemma of Shakespeare's Gertrude”, w: Carolyn Ruth Swift Lenz, Gayle Greene i Carol Thomas Neely (red.), The Woman's Part: Feminist Criticism of Shakespeare, Urbana: University of Illinois Press, 1980: 194-208 
Smith R., „Self-reflection and the Self”, w: Roy Porter (red.), Rewriting the Self: Histories from the Renaissance to the Present, London: Routledge, 1997: 49-60

Starks L. S., „The Displaced Body of Desire: Sexuality in Kenneth Branagh's Hamlet”, w: Christy Desmet i Robert Sawyer (red.), Shakespeare and Appropriation, London-New York: Routledge, 1999: 160-178

Śmietana U., „Histeria. Feminizm. Terapia”, LiteRacje 3(5), 2004: 6-9

Tiffany G., „Anti-Theatricalism and Revolutionary Desire in Hamlet (Or, the Play Without the Play)", Upstart Crow 15 (1995): 61-74

- -----------,Hamlet and Protestant Aural Theater”, Christianity and Literature (Spring 2003): 307-325

Turner V., „Liminalność i communitas”, w: Marian Kempny i Ewa Nowicka (red.), Badanie kultury. Elementy teorii antropologicznej, Warszawa: PWN, 2004: 240-266

Walker E., „A »Harsh World « of Soundbite Shakespeare: Michael Almereyda's Hamlet (2000)”, EnterText 1.2. (Spring 2001): 317-341

Weimann R., „Mimesis in Hamlet”, w: Geoffrey H. Hartman i Patricia Parker (red.), Shakespeare and the Question of Theory, London-New York: Methuen, 1985: 275-291

Wilson R. R., „Narratives, Narrators and Narratees in Hamlet”, Hamlet Studies 6, (1984): 30-40

Xianfeng Mou, „Cultural Anxiety and the Female Body in Zeffirelli's Hamlet”, w: Alexander C.Y. Huang i Charles S. Ross (red.), Shakespeare in Hollywood, Asia, and Cyberspace, West Lafayette: Purdue University Press, 2009: 54-63

\section{Bibliografie szekspirowskie}

Kujawińska Courtney K., Polska bibliografia szekspirowska 1980-2000, Warszawa-WrocławKraków: Wydawnictwo im. Ossolińskich, 2007

\section{Słowniki i encyklopedie}

Baldick Ch., The Oxford Dictionary of Literary Terms, Oxford-New York: Oxford University Press, 2008

Doroszewski W. (red.), Słownik języka polskiego, t. 1-11, Warszawa: PWN, 1958-1969

Stearns P. N. (red.), Encyclopedia of European Social History from 1350-2000, t. 4), New York: Gale, 2001

Wilson N., Encyclopedia of Ancient Greece, New York: Routledge, 2006

\section{Źródła internetowe}

Green R., „Poisoned Ears and Parental Advice in Hamlet”, http://purl.oclc.org/emls/11-3/ greeham2.htm, 4.10.2010

Howes D., „Architecture of the Senses”, http://dawid-howes.com/dttresearch-sampler-archsenses.htm, 2.12.2012

McDermott J. R., „Perceiving Shakespeare: A Study of Sight, Sound, and Stage”, http://purl.oclc. org/emls/si-19/mcdeshak.html, 4.10.2010

Pittman L. M., „A Son Less Than Kind: Iconography, Interpolation, and Masculinity in Branagh's Hamlet", http://extra.shu.ac.uk/emls/11-3/pittham2.htm, 4.09.2010

Robson M., „Looking with Ears, Hearing with Eyes: Shakespeare and the Ear of the Early Modern", http://purl.oclc.org/emls/07-1/robsears.htm, 10.06.2008 


\section{Indeks osób}

Abbate Allesandro 164-166

Almereyda Michael 32, 132-133, 136-138, 142-143, 149-151, $164-168,177-179,183,188-$ 189

Arendt Hanna 53, 64

Aronson Alex 112

Baldick Chris 9

Banks Carol 39-40

Barańczak Stanisław 8, 14

Bourdieu Pierre 36

Bourus Terri 130

Branagh Kenneth 32-33, 130-131, $133-136,138,140-142,146-$ 151, 156-163, 168, 172-176, $179,181-182,187-189$

Brode Douglas 130

Bull Michael 16-17, 29

Burke Peter 61-62

Burnett Mark Thornton 130, 137, $140,142-143,149,162,165$, 183

Burton Robert 106-107

Caldwell Mark L. 30-31, 34-35, 55$56,67-68,78,117,126,128$

Callaghan Dympna 30

Campbell Kathlenn 130

Cartelli Thomas 138

Cartmell Deborah 32
Charney Maurice 39

Cavallaro Dani 26

Chillington Rutter Carol 157

Cieślak Magdalena 130, 170

Clark Stuart 63

Classen Constance 17-19, 21, 52, 65-67

Clemen Wolfgang 68

Collick John 32

Connor Steven 17

Cowden Clarke Mary 169

Cox Lee Sheridan 110

Craik Katherine A. 49-50

Crombie Alistair Cameron 56, 58

Croteau Melissa 149, 151

Crowl Samuel 130, 134, 145, 158

Cummings Peter 93

Dawson Anthony B. 129, 136, 139

Debru Claude 58

Diede Martha K. 79, 111

Doroszewski Witold 64

Dunn Leslie C. 121, 169, 174, 177

Dusinberre Juliet 30

Dutton Richard 142

Dziechcińska Hanna 44

Egan Gabriel 46

Eisaman Maus Katherine 99, 109

Eliot T. S. 12 
Fike Matthew A. 125

Fox Adam 47, 51

Freud Zygmunt 30, 173

Garber Marjorie 123

Gibińska Marta 111

Gouk Penelope 81

Green Reina 94, 102-103

Greenblatt Stephen 26, 31

Gross Kenneth 71, 95-96

Guntner J. Lawrence 32

Gurr Andrew 46-47, 101

Hall Edward 17, 22, 43

Harvey D. Elizabeth 29

Hassel R. Chris 104

Hatchuel Sarah 131, 160, 163

Hillman David 52, 54-55, 58, 62, 86

Hirsch James 160

Holderness Graham 39-40

Holland Norman N. 30

Holland Peter 132

Howard Jean Elizabeth 142

Howes David 9, 15-21, 29

Hudson Lorna 30

Hutcheon Linda 40

Jackson Russel 132

Jay Martin 9, 54, 63-65

Johns Adrian 50, 59

Jones Nancy A. 169, 174, 177

Jütte Robert 18, 23, 43

Kelley Charles Gregg 75-76, 90, 92, 98, 118-119

Kincaid Arthur Noel 104

King R. H. A 57

Kołos Sylwia 146, 152, 157, 177

Kujawińska Courtney Krystyna 37, 125

Lanier Douglas 138, 148

Lawson Chris 139-140, 145, 153,
155-156, 171

Lindberg David C. 57

Luckyj Christina 104

Mahood Molly M. 69

Marcus Leah S. 23-25, 47

McDermott Jennifer Rae 60, 68, 70-71, 73, 84-85, 95, 105-106, 111-112, 115

McEvoy Sean 136, 161, 163

McLuhan Marshall 10

Meek Richard 37, 40, 76-8, 84, 87$88,98,127$

Miola Robert 47

Neely Carol Thomas 3, 121

Norford Don Parry 97

Owens Joana 166

Pajdzińska Anna 53

Palmer R. Barton 26, 42

Paszkowski Józef 14

Pearce Joseph 104-105

Pittman L. Monique 141

Pollard Tanya 109-110

Porter Roy 49, 169

Przeźmiński Jarosław 9, 65

Rasmus Agnieszka 137, 149

Reinhard Kenneth 30

Reinhard Lupton Julia 30

Rembowska-Płuciennik Magdalena 34, 186

Richards Jennifer 50

Robson Mark 45

Rowe Katherine 138

Sawday Jonathan 86

Schoenfeld Michael 57, 60-61

Scolnicov Hanna 176

Selleck Nancy 83, 111 
Sharpe Kevin 48

Showalter Elaine 168-169, 173

Słomczyński Maciej 55

Smith Mark M. 19-20, 43

Smith Rebecca 115

Smith Roger 61-63

Spurgeon Caroline 68

Stam Robert 41-42

Starks Lisa S. 141

Szymborska Wisława 5, 7

Śmietana Urszula 173

Tarnawski Władysław 14, 121

Thorne Alison 50, 55, 61-62, 77, 8283, 88, 96

Tiffany Grace 108, 117

Turner Victor 36
Walker Elsie 132

Weimann Robert 45-46

West-Pavlov Russel 49

Wilson J. Dover 104

Wilson Nigel 57-58

Wilson R. Rawdon 38

Wilson Robert R. 71, 79, 94, 127

Worthen William B. 137

Xianfeng Mou 153

Zamir Tzachi 74, 80

Zawisławska Magdalena 65

Zeffirelli Franco 32-33, 129-136, 138-146, 148, 150-160, 163, 168-172, 179-181, 187-189

Zwicker Steven N. 48 
